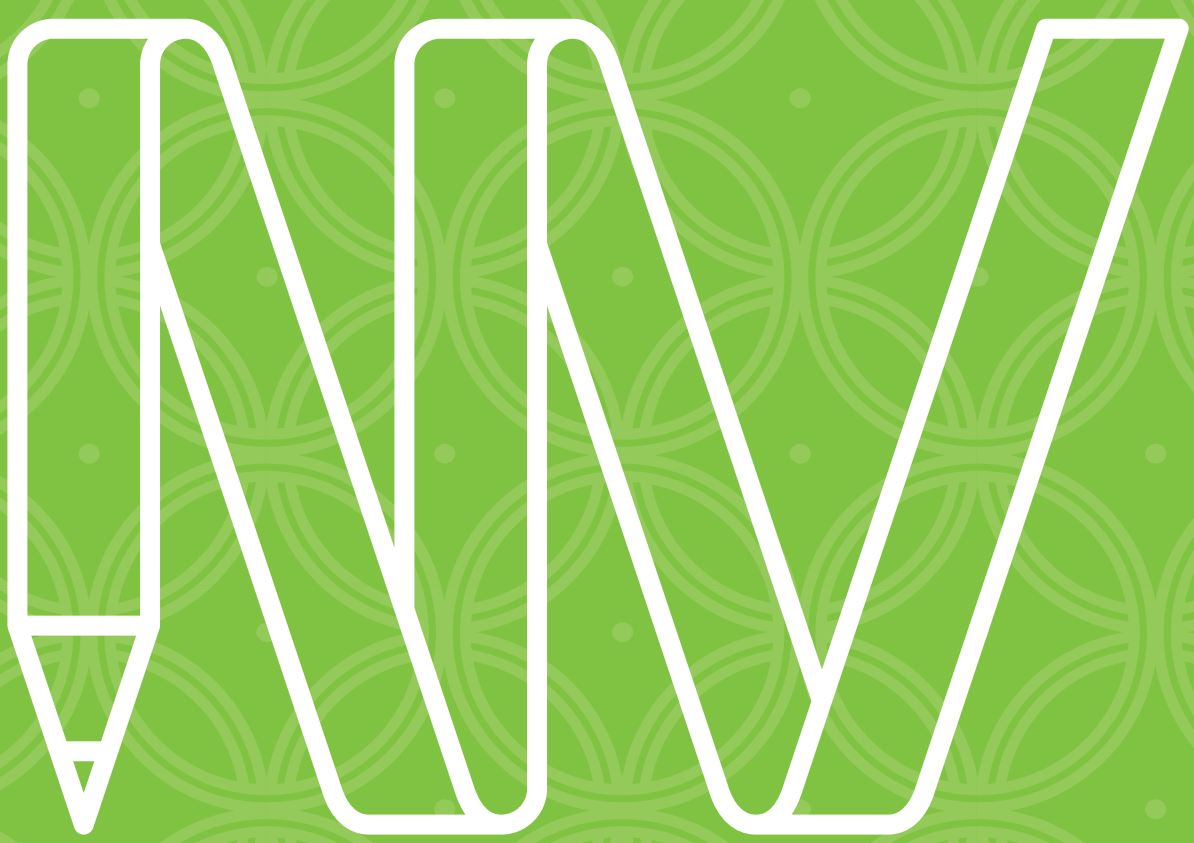

\title{
NEWVOICES IN JAPANESE STUDIES
}

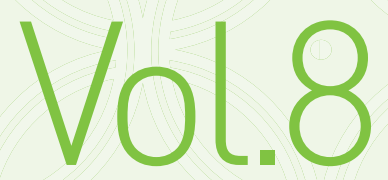




\section{New Voices in Japanese Studies Volume 8}

\section{An interdisciplinary, peer-reviewed journal showcasing the work of emerging scholars from Australia and New Zealand with research interests in Japan.}

\section{GUEST EDITOR, VOLUME 8}

Dr Adam Broinowski, Australian National University

EDITORIAL ADVISORY BOARD (in alphabetical order)

Professor Kent Anderson, University of Western Australia

Associate Professor David Chapman, University of Queensland

Dr Laura Dales, University of Western Australia

Dr Christine de Matos, The University of Notre Dame Australia

Dr Elise Foxworth, La Trobe University

Emeritus Professor Nanette Gottlieb, University of Queensland

Dr Carol Hayes, Australian National University

Dr Emerald King, Victoria University of Wellington

Dr Yasuko Hassall Kobayashi, Australian National University

Dr Xiangdong Liu, Western Sydney University

Professor Vera Mackie, University of Wollongong

Professor Gavan McCormack, Australian National University

Dr Katrina Moore, University of New South Wales

Professor Tessa Morris-Suzuki, Australian National University

Dr Caroline Norma, RMIT University

Dr Craig Norris, University of Tasmania

Professor Akihiro Ogawa, University of Melbourne

Professor Junko Otani, Osaka University

Dr Emi Otsuji, University of Technology Sydney

Dr Yuji Sone, Macquarie University

Associate Professor Roy Starrs, Otago University

Dr Leonie Stickland, Murdoch University

Dr Katsuhiko Suganuma, University of Tasmania

Associate Professor Takemasa Ando, Musashi University

Dr Beatrice Trefalt, Monash University

Associate Professor Leon Wolff, Queensland University of Technology

\section{SERIES EDITOR}

Elicia O'Reilly, The Japan Foundation, Sydney

\section{HEAD OF DEPARTMENT}

Ayusa Koshi, The Japan Foundation, Sydney

All submissions to New Voices in Japanese Studies are peer reviewed by a board of independent academic experts to meet the HERDC requirements for refereed journal status. This and other volumes are available for download via the New Voices in Japanese Studies website and the Directory of Open Access Journals.

www.newvoices.org.au | www.doaj.org

The views expressed in this journal are those of the authors, and do not necessarily coincide with those of the editors, the members of the Editorial Advisory Board or The Japan Foundation, Sydney.

Japanese names are written in first name-surname order, in accordance with English-language convention. The long vowel sound in Japanese is indicated by a macron (e.g. kōtsū), unless in common use without (e.g., Tokyo).

\section{PUBLISHED BY}

The Japan Foundation, Sydney

Level 4, Central Park

28 Broadway, Chippendale NSW 2008

www.jpf.org.au

July 2016

New Voices in Japanese Studies, Volume 8 is copyright @ The Japan Foundation Sydney and the authors. Copyright of the collection belongs to The Japan Foundation, Sydney. Copyright of the work belongs to the authors. All third-party images have been reproduced with permission and copyright remains with the original copyright holders.

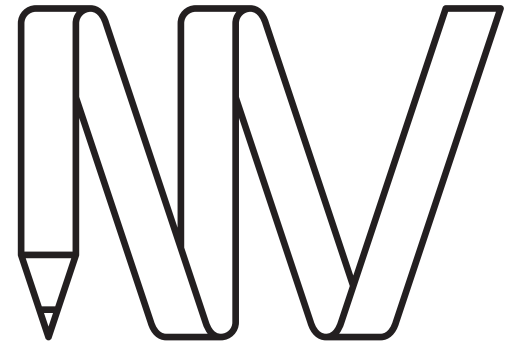

NEW

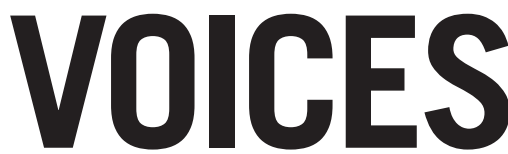

IN JAPANESE STUDIES

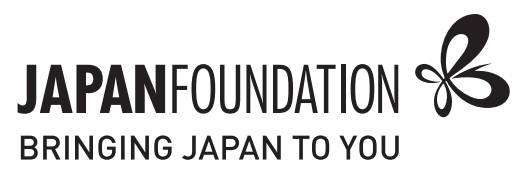

To link to this volume:

http://dx.doi.org/10.21159/nvjs.08

ISSN 2205-3166

All articles can be downloaded free at newvoices.org.au

(c) The Japan Foundation, Sydney, 2016

\section{(c) (i) $\$$}

With the exception of images or other material identified as copyright of a third party, this content is licensed under the Creative Commons AttributionNonCommercial-NoDerivatives 4.0 International Licence. All other rights reserved. Permission requests for usages outside those governed by this licence should be directed to the Series Editor at newvoicesajpf.org.au.

We request attribution as follows: (C) The Japan Foundation, Sydney / [author name], [year of publication].

New Voices in Japanese Studies,

Vol. 8, 2016 


\section{Foreword}

Welcome to Volume 8 of New Voices in Japanese Studies (NVJS). This is the second volume we have published since renewing the journal in 2015. In this edition, we are delighted to present six articles by local new voices that engage with a broad range of complex and challenging themes. It is my hope that publication in this journal will stand these authors in good stead, both now and in the years to come.

It has been a distinct pleasure to have Dr Adam Broinowski on board as Guest Editor for this volume. Ten years ago, as a $\mathrm{PhD}$ candidate, Dr Broinowski contributed an article to the very first issue of this journal. We are honoured to be able to welcome him back to the journal this year in an editorial capacity, and we are confident in the knowledge that the articles in this volume have benefited from the unflagging dedication, rigour and professionalism that has characterised his engagement with this project from beginning to end. On behalf of the NVJS team, I wish to express my sincere gratitude to Dr Broinowski for the time and expertise that he has so generously devoted to shaping this volume. It has been very much a privilege for us to work with him.

Great thanks are also due to the members of this year's Editorial Advisory Board, who so generously gave of their time to provide feedback on the submissions to this volume. Many of these academics have also loaned their expertise to previous volumes of the journal, and have encouraged postgraduate researchers to submit their work. It is only thanks to the continued support of our local academic community that we are able to produce NVJS, and I am glad of the opportunity to express my heartfelt appreciation for it.

As you may be aware, NVJS has continued to evolve over the past year. Since our last volume was published, we have completed the transfer of back issues onto our current site, so that all articles are now available in full in the one location. We have begun an affiliation with Crossref, which helps to make NVJS articles easier to search, cite and access, and have adopted a Creative Commons licensing model to support greater use of our authors' articles. Further, we have also renewed our affiliation with the Directory of Open Access Journals, which benefits our authors by its valuable indexing of NVJS and the work within it.

But by far the most important development for NVJS this year is the launch of the New Voices Scholar program. This program supports NVJS authors to present their work at local conferences, thereby providing an additional opportunity 
to build skills, experience and an academic profile. For this inaugural year, we are proud to support Ross Tunney of the University of Tasmania, whose article, "Imaging the Rural: Modernity and Agrarianism in Hiroshi Hamaya's Snow Land Photographs" was published in Volume 7, and Geraldine Carney of Monash University, whose paper, "Disrupt, Support and Document: The Role of Social Media in International Child Abduction Cases Involving Japan" appears in this volume. It is an honour and a privilege for us to support these outstanding young scholars, and we look forward to continuing this program as an extended platform for future NVJS authors.

The above changes would not have been possible without our Series Editor, Elicia O'Reilly, whose dedication and vision has ensured that NVJS is continually changing for the better. Nor would they have been possible without the enthusiasm and support of Supervising Manager, Ayusa Koshi. They also owe much to Penny Maher, whose incredible efficiency and hard work as Administrative Assistant was responsible for bringing many of them into effect. And here, I would also like to acknowledge our web and layout designer Kevin Vo, whose tireless assistance with matters both technical and visual has enabled us to improve the journal over the past year as well as release this latest volume. I thank each of you most sincerely for your invaluable efforts.

Finally, I wish to thank the authors who chose to submit their work to this volume, and who have shown great discipline and tenacity in responding to feedback and dealing with the challenges of peer-review-many for the first time. Your publication in this volume is all the better for the time and energy that you devoted to the revision phases, and for this I congratulate you heartily. My deep thanks also go to our authors' academic supervisors, who encouraged them to submit and took the time to recommend their papers to us. And for the authors who, due to the pressures of time, were unable to complete their revisions in this cycle, we look forward to seeing your names in a future issue of NVJS.

Yoshihiro Wada

Director

The Japan Foundation, Sydney

July 2016 


\section{Contents}

Foreword

v Introduction

Dr Adam Broinowski

1 Disrupt, Support and Document: The Role of Social Media in International Parental Child Abduction Cases Involving Japan Geraldine Carney

32 The Cultural Semantics of the Japanese Emotion Terms

'Haji' and 'Hazukashii'

Gian Marco Farese

55 A Centaur in Salaryman's Clothing: Parody and Play in est em's Centaur Manga

Anne Lee

77 Visualising Shattered Lives: Potentiality in Representations of Rape Victimisation in Contemporary Japanese Cinema Hei-Lei Cheng

98 The Angst of Youth in Post-Industrial Japan: A Narrative Self-Help Approach

Rie Kido

Performing Femininity in Japanese Politics: Chikage Ōgi

Case Study

Alison Luke 
It has been a pleasure to work as Guest Editor for New Voices in Japanese Studies, Volume 8. We have several wonderful and fascinating articles from excellent emerging researchers who combine their scholarship in Japanese Studies with other disciplines, including legal studies, linguistics, cultural, media and gender studies. In a time when Japan, as part of a world economy, is undergoing significant transformations, the articles collected in this volume share informed perspectives on several issues specific to Japanese society that also have international relevance.

The work of these scholars demonstrates the importance and necessity of the broader movement in the humanities and social sciences to continue to complicate fixed binaries and challenge familiar assumptions so as to more accurately reflect, respond to and ultimately re-make realities being lived in late-capitalist society in Japan, and elsewhere. Rather than cushioning education with safety and reassurance in settled and boundaried terms of reference, knowledge derives from the capacity to engage empathetically with unsettling realities while seeking deeper truths. From the university to the public sphere, scholars should be permitted and encouraged to exercise their skills in questioning received wisdom and perform their civic responsibility to address issues of violence, oppression and injustice and the conditions that produce them. Not to do so is to abrogate the validity of social values and rights that are crucial to the formation of independent-minded citizens who have a stake in the direction of their society. The collection of scholarly articles in this volume show promise in this direction.

Geraldine Carney examines international parental child abduction cases to and from Japan, with a focus on cases of abduction to Japan. She investigates the present situation of custody laws in Japan and argues that, given that the law has not adapted to the increase in families of mixed nationalities, conditions are such that parents are turning to social media in attempts to improve their situations. Citing a number of parental child abduction case studies in which social media has been used by concerned parties, Carney provides detail on the state of Japanese custody laws vis-àvis the needs and expectations of parents and children both within and outside Japan. In particular, she argues, in cases where left-behind parents whose custodial and visitation arrangements with their child are restricted due to legal preference for sole custody under Japanese family law, social media provides opportunities to document and publicise their cases and to form horizontal community networks with disparate and concerned (1) 
others in similar situations. Where there is little legal incentive for custodial parents to encourage or facilitate contact with the non-resident parent, Carney finds that social media is a viable channel through which left-behind parents can perform advocacy, seek support and exert social pressure to improve these conditions. The implications of the article are compelling regarding changing conceptions of the family due to increasing internationalisation, including in Japanese society.

Gian Marco Farese provides a cultural semantic analysis of the Japanese words 'haji' and 'hazukashii' to demonstrate the potential of the Natural Semantic Metalanguage (NSM), the system of cross-translatable words which forms the methodological basis of the article. In order to avoid privileging the linguacultural meanings embedded in their English correlates, he explores the terms 'haji' and 'hazukashii' as distinct emotion terms which are linguistically and culturally specific to the Japanese context. In showing how their English translations are typically used in examples from a Japanese dictionary and modern and contemporary Japanese literature, Farese argues that their typical translation as 'shame' or 'embarrassment' is insufficient and not culturally neutral. After identifying the differences in cultural salience of 'haji' and 'hazukashii' in the Japanese context, Farese's challenge is to describe these terms in words which are recognisable as indigenous by native speakers of Japanese and also understandable to cultural outsiders. He demonstrates the suitability of NSM for elucidating these differences in simple and cross-translatable words. Farese's study contributes to a less-homogeneous understanding of emotions themselves as part of a broader study of the relationship between language and culture.

Anne Lee examines two manga by est em (esu to emu), Hatarake, kentaurosu! and equus, which focus on male centaurs in homosocial settings, positioning them within both shōjo manga and Boys' Love (BL) manga traditions. est em's focus on the figure of the centaur in realistic, everyday settings in contemporary Japanese society evokes homoerotic subtexts and intertextual parody for the enjoyment of mostly female readers. Unlike the chaotic and hypersexualised qualities of centaurs in Greek mythology, Lee maintains that est em uses this as a device to subvert and unsettle mainstream constructs of sexuality and masculinity found in typical salaryman culture. Rather than directly protesting patriarchal and heterosexist oppression, the centaur is a humorous device to playfully undermine restrictive heteronormative roles engendered in popular culture. At the same time, Lee's analysis considers these manga as also incorporating criticism of the way in which otherness and/or femininity, as embodied by the centaur, is marginalised in the closed homosocial world of the Japanese workplace. By way of example, Lee contrasts Kintarō, a model of a brash, hyper-masculine corporate worker in Sarariiman Kintarō, with Kentarō, the impeccably mannered centaur in est em's Hatarake, kentaurosu!, to demonstrate how Kentarō's difference excludes him from the hegemonic ideal. She also explores how est em's human-centaur friendships are either nioi-kei, with a hint of homoeroticism, or are more direct male-male centaur romances of mutual consensual pleasure, as in equus, for a BL readership. Producing homoerotic centaurs for readers' delectation 
while challenging dominant constructs of heterosexuality and hegemonic masculinity appears to Lee to be an appealing way to provide temporary relief in late-capitalist Japanese society.

Hei-Lei Cheng analyses how cinematic representations of rape and rape recovery can challenge the notable paucity of public debate surrounding the issue of sexual violence and its representations in popular media in Japanese society. Through a textual analysis of two contemporary fictional Japanese films, DV: Domestic Violence and The Ravine of Goodbye, Cheng examines the ways in which narrative and cinematographic techniques are used to construct rape and domestic violence scenes that encourage critical reflection rather than reinforce dominant stereotypical assumptions about rape and rape victims. Based on the idea that knowledge formation is embedded in a dynamic process of mutual feedback between the individual and society in flux, she perceives mass media as important institutions for shaping public consciousness as they reflect, repeat and normalise values, beliefs and attitudes entrenched within a nation's cultural and social history. As production and consumption increases in the mediated social sphere, viewers can access alternative viewpoints that challenge hegemonic perceptions. Citing feminist media critics in Japan and the United States, Cheng argues that gendered stories of rape and rape victims that deny gratuitous pleasure and destabilise exploitative portrayals of sexual violence in popular culture have the potential to transform the collective imagination. She observes how these filmmakers discursively engage, and create space for, viewers to consider some of the realities of working through painful and traumatic experiences of sexual abuse. Through uncomfortable glimpses of the nature of trauma and its overcoming from the victims' perspectives, Cheng maintains that these otherwise silenced experiences are at least brought into public consciousness where viewers can decide to shift their received perceptions on sexual violence and to become advocates against sexual violence against women. While urging for widespread ethical reflection and collective activism on these issues in Japanese society, this also implies the need for critical awareness of the fictional devices utilised by media makers in the process of knowledge formation.

Rie Kido shares her findings from action research and participant observations in a Self Help Group for young people in Osaka who experience angst exacerbated by precarious socio-economic conditions. Employing Karin Amamiya's term ' ikizurasa' to describe youth angst amid the neoliberal economic climate in Japanese society, Kido proposes that a narrative method and the non-judgmental space used in the Self Help Group allows affected youth to share their feelings and experiences without the direct pressure of having to find a job. While complementary to a variety of existing supports such as psychiatric treatment and government activation programs for chronically underemployed people, Kido argues that this Self Help Group narrative method is useful for helping youth who are less equipped to be resilient in times of stress to avoid alienation, build motivation and develop relationships in a trusting environment. As a form of self-reinvention, Shimizu maintains that these focused narrative sessions assist the individual 
to clarify their needs, rebuild their confidence and self-respect, and develop a sense of connection with others who share similar experiences to practically and positively envisage their lives and careers anew. Instead of considering unemployment as a temporary situation, Shimizu contends that it should be accepted as a chronic reality to live with. At the same time, she acknowledges that this focus on reinventing personal narratives and identity should not be used to ignore the need for change in labour conditions so as to properly address the underlying causes of social marginalisation that affects a significant portion of the population. Ultimately, the self-help narrative approach helps to augment existing programs in adapting to the diverse needs and expectations of a range of young people and to help them find a place in society that is more suitable to them.

Alison Luke addresses the life of Chikage Ōgi to examine how one of the most successful female politicians in Japan negotiated the structural constraints to women's participation in the political sphere. Ögi's career began in the entertainment industry with a five-year stint as a musumeyaku in the Takarazuka Revue, followed by a role as host of a popular television program. Luke contends that this, along with her familial socialisation, equipped her with the performative skills to enact gender-role expectations while realising her ambitions over her life course. In response to persistent gender inequality in Japan's male-dominated conservative political sphere in which women's presence has been regarded as unusual and unnatural, Luke finds that Ōgi was able to deploy her creative and practical skills to turn cultural expectations about women's primary roles as housewives and mothers to her advantage in political campaigns and forums by appealing to conservative values of authenticity, trustworthiness and suitability. While capitalising on an idealised feminine image and significant male patronage enabled Ōgi to ascend to leadership roles and ensured her political longevity, this came with the cost of actively reproducing these normative constructs in a non-threatening manner within the masculine culture of the Liberal Democratic Party. Nevertheless, Luke argues that Ögi's displays of individual autonomy and deft manipulation of her networks belies her performances of acculturated femininity and undermines the assumption that she represents nothing more than a political asset. Instead, Luke finds that Ōgi's political career owes much to her not confronting but embracing gender expectations among other things in order to achieve her political goals.

I am grateful to Elicia O'Reilly, Series Editor and Ayusa Koshi, Manager at The Japan Foundation, Sydney for this stimulating and rewarding experience. There were several who did not make it into this volume but we encourage them and others to submit their work to New Voices in Japanese Studies, Volume 9. Many thanks again to the dedicated work of Elicia O'Reilly with whom it has been an absolute pleasure to work on these fine research articles.

Dr Adam Broinowski

Australian National University 


\section{Disrupt, Support and Document: The Role of Social Media in International Parental Child Abduction Cases involving Japan}
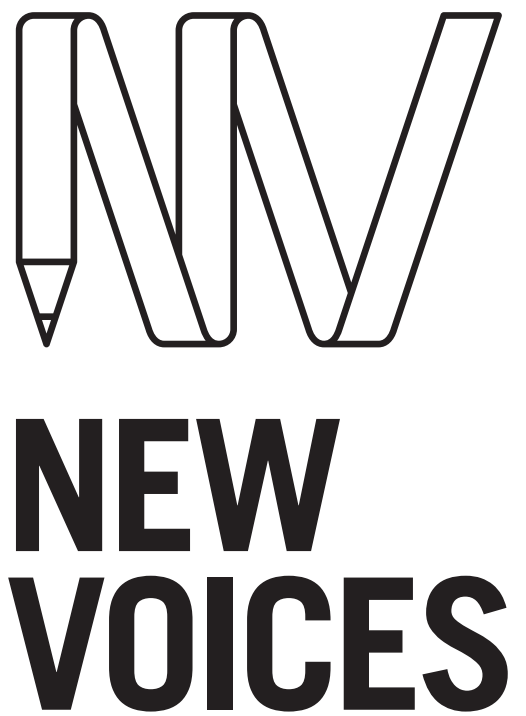

IN JAPANESE STUDIES

\section{GERALDINE CARNEY}

Monash University

\section{ABSTRACT}

In this article, I examine the use of social media by parents involved in cases of international parental abduction to and from Japan, with a focus on cases of abduction to Japan. I argue that the use of social media in these cases is a symptom of and a counter to a legal system which has been outpaced by changes in society, particularly the creation and dissolution of international families. This article discusses a number of case studies of social media usage and locates these in the context of the contemporary Japanese legal system. While not ignoring the nefarious potential of social media usage, I come to a positive assessment of its use in cases of international parental child abduction involving Japan. I also question how its utility will change over time, depending on the legal system's ability to adapt to societal changes and expectations.

\section{KEYWORDS}

custody disputes; Facebook; family law; human rights; intermarried families; international law; international relations; internationalisation; law; media; parental child abduction; social media; technology

\section{JAPANFOUNDATION \& \\ BRINGING JAPAN TO YOU \\ To link to this article: \\ http://dx.doi.org/10.21159/nvjs.08.01}

\section{ISSN 2205-3166}

New Voices in Japanese Studies is an interdisciplinary, peer-reviewed journal showcasing the work of emerging scholars from Australia and New Zealand with research interests in Japan.

All articles can be downloaded free at newvoices.org.au

(c) The Japan Foundation, Sydney and Geraldine Carney, 2016

\section{cc) $\$$}




\section{INTRODUCTION}

Every character and function that interactive digital media facilitates can be seen as double-sided, where the dark side inevitably connects to the light.

(Åkerström 2015, 120)

The advent of social media has affected almost every aspect of contemporary life. The political and legal spheres concerned with creating policy for control and implementing these policies through law are still coming to grips with how their work is changing in the wake of new forms and unprecedented levels of social communication. At times, the heightened level of social connection produced by social media aids policy making and justice; at other times, it complicates and disrupts.

The area of human rights offers many examples of the complicated intersection between legal and political processes and the use of social media. For example, social media was lauded for its role in the democratic uprisings known as the 'Arab Spring' in the Middle East and North Africa region in 2011, where it provided freedom of expression and a means of organising in otherwise tightly controlled societies (see Khondker 2011; Joseph 2012). Even so, others have argued that social media can be used as an insidious form of social control and surveillance by state agencies (see Morozov 2011; Fuchs et al. 2012).

One human rights issue which has become more prominent in an increasingly connected and internationalised ${ }^{1}$ world is that of cross-border child custody issues and, in particular, international parental child abduction. ${ }^{2}$ This paper examines the issue of cross-border parental child abduction ('international parental child abduction') involving Japanese nationals. In particular, it considers the role that social media plays in cases of international parental child abduction, which are by their very nature emotionally charged and often politically and legally complex.

I argue that custody laws in Japan are being outpaced by changes in society. That is, the legal system is struggling to address issues arising from the union and dissolution of international families which are now common in Japanese society, as well as the increasingly vocal refusal of parents, Japanese and non-Japanese alike, to be excluded from their children's lives after divorce. ${ }^{3}$

1 This paper adopts the explanation of internationalisation proffered by Breaden and Stevens $(2014,4)$ as a "conscious and often intentional" process in which the action is the focus, as opposed to globalisation, in which the product is the focus. This theoretical basis seems most appropriate in the context of cross-border relationships as acts of internationalisation, albeit in a globalised world.

2 International parental child abduction is also a human rights issue, from the viewpoint of many Western family law systems that it is "largely unquestionable" that most children benefit from an "ongoing, warm and available involvement of both parents, in a climate of well-managed interparental conflict" (McIntosh 2009, 389; see also Jaffe 2014). While it is out of the scope of this paper, of relevance is the discussion as to the existence of human rights (see Mégret 2011, 200-204), as well as whether parents can be regarded as having rights with respect to their children (as opposed to duties and obligations) (see Austin 2013).

3 A Tokyo Family Court committee meeting in December 2011 recognised that visitation cases handled by the Japanese family courts between 1999 and 2010 had increased 3.6 times, and the proportion of applications made through the Japanese family courts by fathers had also increased from $53 \%$ to $66 \%$ in that time (Supreme Court of Japan 2011, 3-4). The committee noted various reasons for the increase in applications for visitation by fathers after divorce: an increase in the overall number of divorces, the changing role of the father and the increase in the number of households where mothers and fathers split the management of the household and child-rearing, and a change in societal views about the importance of visitation by the non-custodial parent (Supreme Court of Japan 2011, 4-6). 
As the legal system does not keep pace with social developments, social media is utilised by concerned parties to help fill the gap: to document their cases, call for support and sway public opinion, and potentially disrupt the status quo on custody issues.

The relationship between social media and the advancement of human rights is complex, multi-layered and still emerging. It is a relationship which is double-sided, as suggested by Åkerström (2015) above. While not ignoring the tension in this relationship and the "dark side" $(2015,120)$ of mass digital communication, I argue for an ultimately optimistic assessment of the role of social media in international parental child abduction cases involving Japan, as it can assist parties involved to at least partially fill the gaps in the available legal remedies. I also recognise the changing legal landscape in Japan and suggest that the role of social media in international parental abduction cases may alter over time.

\section{INTERNATIONAL PARENTAL CHILD ABDUCTION AS A JAPANESE STUDIES ISSUE: THE LEGAL “BLACK HOLE” OF JAPAN}

Parental child abduction occurs when one parent removes their child or retains them in breach of the other parent's rights of custody according to laws of the jurisdiction governing the parent-child relationship prior to the removal or retention. There is a raft of international and domestic laws and regulations designed to decrease the incidence of parental child abduction and to offer legal relief to 'left-behind parents' whose children have been parentally abducted. Parental child abduction is not a new phenomenon. However, it only began to be regarded as a legal and social problem in the 1970s, in the wake of growing public concern regarding child welfare and issues which were traditionally considered private affairs, such as family violence (Greif and Hegar 1993). Much of the early research which posited parental child abduction as an important social issue grew from the American legal and psychosocial context (e.g. Bodenheimer 1977; Terr 1983; Agopian 1984; Sagatun and Barrett 1990).

International parental child abduction-that is, parental child abduction occurring over national borders-is an increasingly common corollary of the rise of internationalisation, forces of globalisation and accompanying human mobility between nationalities, ethnicities and cultures. ${ }^{4}$ Certainly, these factors have affected Japanese citizens' work, education, travel and leisure choices, and have inspired the flow of people across its borders in an unprecedented way. Transnational relationships are increasing. The number of marriages in Japan where one spouse is of a nationality other than Japanese increased five-fold between 1965 and 2014, from 4,156 to 21,130 (Ministry of Health, Labor and Welfare 2014, Table 9.18).

This trend is reflected at a judicial and administrative level in Japan: the total number of new international family law cases handled by Japanese family 
courts has grown from 5,726 in 2000 to 8,441 in 2014, representing a $47.4 \%$ increase (Supreme Court of Japan 2000, 26; Supreme Court of Japan 2014, 30). ${ }^{5}$ Of those cases, the number identified as involving the designation of physical custody of a child and related issues, or the designation or alteration of legal custody of a child, increased from 656 to 1295, representing a 97\% increase (Supreme Court of Japan 2000, 26; Supreme Court of Japan 2014, 30). The total number of cases of the same designation (international and domestic) handled by Japanese family courts in the same period rose 79\% (Supreme Court of Japan 2000, 6-7; Supreme Court of Japan 2014, 8-9). This difference does not necessarily indicate that the actual number of international custody disputes is increasing at a faster rate in Japan, but it does establish that these cases are rapidly becoming more visible at an institutional level.

It should be noted that these statistics are only indicative of a potentially much larger issue, as the vast majority of divorces in Japan are completed by consent and without the involvement of the family courts or other third party: the requisite paperwork is simply completed by the parties and filed with the local government office (Jones 2007, 205; Tsuneoka 2013, 40). These divorces by consent are known as kyōgi rikon (協議離婚) ${ }^{6}$, and constituted $87.4 \%$ of divorces in Japan in 2014 (Ministry of Health, Labor and Welfare 2014, Table 10.4). It follows that the overall number of children of failed international relationships would be much greater than the number of judgements and mediations for these types of cases. Also, these figures do not necessarily reflect divorces involving Japanese citizens that are concluded overseas.

The number of children parentally abducted to and from Japan is unknown. Up until recently, there has been no formal mechanism for recording abduction cases in Japan, and governments of other countries have relied on reports made voluntarily to them by aggrieved parents. As of 2013, the United States counted 100 active cases of abduction to Japan involving more than 140 children (U.S. Department of State 2013). There were also reported to be at least 37 British nationals involved in parental abduction cases to Japan as at 2013 (Ryall 2013), and 33 cases of reported abductions of French children to Japan (Vaulerin 2013). In Australia, there are reports of up to 15 children having been abducted to Japan (Australians with Abducted Children 2013). While the precise number of international parental child abduction cases is unclear, there is evidence that they are becoming more frequent. The U.S. Embassy in Japan (2010) reported that the number of international parental child abductions to Japan tracked by the United States, the United Kingdom, Australia, Canada and France indicated that parental child abductions to Japan from these five countries had almost doubled in the previous two years, and more than quadrupled in the previous four years.

These figures may not reflect the true magnitude of the issue, when it is considered that the overwhelming majority of transnational marriages in Japan involve individuals from countries outside North America, Australia and Europe. In 2014, non-Japanese brides hailed from China and the Philippines

5 In Japan, international family law cases are defined as judgements or mediations (調停) in which at least one of the parties is non-Japanese.

6 This and other Japanese terms used are listed in a glossary at the end of this paper.

Geraldine Carney New Voices in Japanese Studies, Vol. 8, 2016, pp. 1-31 
in $40.1 \%$ and $20.0 \%$ of cases respectively, while non-Japanese husbands were most commonly Korean (North and South), accounting for $27.7 \%$ of transnational marriages with Japanese wives in the same year (Ministry of Health, Labor and Welfare 2015, Table 9.19; Ministry of Health, Labor and Welfare n.d.). The predominance of these particular pairings is reflected in the numbers of international divorce-related cases handled by the family courts in Japan. In 2014, cases involving a Filipina wife and Japanese husband accounted for 381 of 1,949 international divorce-related cases (approximately $19.5 \%$ ), while cases involving a Chinese wife and Japanese husband accounted for 265 cases (approximately 13.5\%), by far the highest-ranking pairings amongst the tallied cases (Supreme Court of Japan 2014, 50). In cases involving non-Japanese husbands, disputes between South Korean husbands and Japanese wives were the most common, accounting for 87 cases of the 1,949 international divorce-related cases (approximately 4.4\%). The incidence of parental abduction cases within these groups is unknown.

Given the lack of rigour in the reporting of international parental abduction cases, it can be difficult to distil any significance from a comparison of abductions to and from Japan with international parental abduction figures globally. However, to provide context, the Hague Conference reported in its most recent statistical analysis in 2011 that the number of return applications (the request to have a child returned) registered in 2008 by 60 of its then 81 contracting states was 1,961, involving 2,705 children (Hague Conference on Private International Law 2011, 5, 6 and 10). These statistics are heavily qualified by the fact that they do not account for abductions within state borders or where return applications were made under other inter-country agreements $(2011,5)$.

Japan's management of international parental child abduction cases involving its citizens has attracted sharp criticism from the international community for many years. Despite there being some public interest in parental child abduction involving Japan at an earlier stage (e.g., Buckland 2006), it is arguable that the issue did not gain full public attention until 2009, when Tennessee resident Christopher Savoie was arrested and spent eighteen days in jail in Fukuoka, Japan, on suspicion of attempted abduction of his two children from his Japanese ex-wife, Noriko Savoie (Lah 2009). Noriko Savoie had removed the children to Japan from the United States in violation of a Tennessee court order granting Christopher Savoie rights of access (Warner 2010, 50). The facts of the Savoie marriage, divorce and custody dispute are, like any, complex and nuanced, but the story gained international coverage and was framed by the English-language media in simplified terms as a battle between American and Japanese law and culture (e.g., Saltzman 2009). Christopher Savoie was not the first left-behind parent to be arrested in these circumstances, but his case was credited with raising public awareness internationally and precipitating increased diplomatic pressure on Japan to address cases of custody disputes in a more balanced way (Saltzman 2009; see also Toland 2011).

Japanese society has often been described by English-language media as a "black hole" (e.g., Jones 2011b; Willacy 2012) or "haven" (e.g., Birmingham 2011; McCurry 2013) for parental abduction. Many commentators, predominantly 
in the mainstream western media, have lamented the dearth of legal avenues available in Japan to left-behind parents to assist in locating children and enforcing their custodial or visitation rights as recognised in another state (Dingle 2011; Bramham 2013). In particular, Japan has been criticised for protecting Japanese abductors and freezing out foreign parents from the lives of their children (Buerk 2011). The criticism levelled at the Japanese legal system's handling of international parental child abduction cases has been directed at two key areas: namely, the way parental abduction cases are handled within the domestic legal system, and Japan's engagement with international law. In 2014, Japan became a contracting party to the Hague Convention of 25 October 1980 on the Civil Aspects of International Child Abduction ('Hague Abduction Convention'), which is the key legal mechanism in international law to address the issue of international parental child abduction. This was an important milestone in the management of parental child abduction by Japan and provided a new focus for the narrative of this international social, legal and political issue.

\section{THE ROLE OF SOCIAL MEDIA IN INTERNATIONAL PARENTAL CHILD ABDUCTION CASES}

Despite its wide use in social, commercial and academic contexts, the term 'social media' tends to defy conventional academic definitions due to its disparate and evolving nature. It may be broadly understood as a set of mobile and web-based platforms which allow users to generate and share online content for the purpose of collaborating and building networks and communities, with the potential for connecting with a larger audience (El Ouirdi et al. 2014, 123).

\section{Methodology}

Case studies of parents involved in parental child abductions are a key source of data in my larger research. The case of the Savoie family provided a natural starting point for my case study selection, as it is very visible in both a discursive and practical sense. The case is widely cited and employed to frame a narrative for the issue, at least in English-language media and academic works that critically address the legal approach of the Japanese government. The awareness raised by the Savoie case has also translated into increased political and diplomatic pressure on Japan to change the way the Japanese government handles cases of parental abduction. In this way, the case signifies a turning point in the international history of the parental child abduction issue. Many elements of the Savoie case were extraordinary. For this reason, the case is a valuable source of information and can perhaps provide further insight into the legal conditions in Japan, beyond its own specific set of facts (see Flyvbjerg 2006, 229-33).

In selecting my other case studies, I have sought to provide a counterpoint to the Savoie case by selecting cases that involve a range of legal systems and traditions, countries and family relationships. I employ a thematic narrative 
analysis (see Riessman 2008, 53-76; see also Polkinghorne 1995 on the "analysis of narrative") to identify common threads and points of discord in the cases. I further employ a narrative constructionist approach to connect the narrative to the historical, political and sociocultural context (Esin et al. 2013, 20315). ${ }^{7}$ This approach is consistent with the sociolegal conceptual framework, which seeks to contextualise legal developments rather than treating them as self-contained subjects of analysis. My guiding thesis is that there are gaps arising between the current state of Japanese divorce and custody laws and the increasing internationalisation of marriage.

Some of my selected cases are easily located in mainstream media. Others have attracted little or no publicity at all. While some left-behind parents may, understandably, seek to protect their privacy, others wish to share their stories. Social media is an enabler to fill the gap between the realities of international parental child abduction and their portrayals in mainstream media, and can offer another layer to an individual's story. Analysis of the use of social media in my selected case studies led to important additional findings as social media performed the dual role of data collection tool and a site of narrative enquiry (see Squire et al. 2014, 47-48).

\section{Limitations of Social Media as a Research Tool}

While social media is an important tool of contemporary activism (for further discussion see Postmes 2007, 174-79), its usage is heavily tempered by disparate individual circumstances (see Hargittai 2007). This study aims to highlight the different ways in which parties to parental abduction employ social media as an adjunct to the available legal options. It is beyond the scope of this study to address correlations between individual circumstances and social media usage, or to quantify or exhaustively categorise social media usage.

Social media can be conceptualised as a conduit through which individuals present and inhabit a particular image of themselves (Manago et al. 2008). This conceptualisation is a natural extension of the seminal work of Erving Goffman on the presentation of the self (1959). Custody disputes have the potential to firmly entrench parents in polarised positions, perhaps even more so in cases involving Japan, given the 'all or nothing' custody scenario often presented to parents under the family law, as elaborated upon below. It is therefore important to view the social media sites produced in this context with caution and accept that they may be, consciously or not, a presentation of one parent's version of events rather than an objective 'truth'.

\section{The Use of Social Media in Parental Child Abduction Cases}

As well as filling in a gap left by mainstream media coverage, social media content created by both individual and groups of left-behind parents, including Facebook pages, tweets, blogs and online forums, assists to fill the vacuum between the realities of international parental child abduction and 
the legal solutions available to left-behind parents. While this gap creates bitter disappointment, helplessness and despair at the outcomes achievable through law, social media provides an extra-legal platform for left-behind parents to connect and share information with other parents in the same position, wherever there is internet access in the world. It also provides a virtual space for them to continue to advocate for change, even though their individual cases may be lost in legal terms. In some cases, content generated by left-behind parents can play a complementary role to the legal process by providing practical information to other left-behind parents regarding their legal options.

One prevalent way that left-behind parents participate in social media is by joining or subscribing to an online group. The Japan Children's Rights Network (also known as CRN Japan) is an early example of this type of group. Established in 2003, its stated mission is to "disseminate information to help change attitudes and laws in Japan in order to assure all children of direct, meaningful and continuing contact with both parents, regardless of citizenship, marital status or gender" (The Japan Children's Rights Network, n.d.[a]). The group provides a multitude of online resources for left-behind parents, including information on Japanese family law and the practicalities of pursuing custody rights in Japan (such as assessments of local lawyers), as well as a web-based service to assist children in contacting left-behind parents and a space for online discussion. The group also plays a role in assisting parents who suspect their children are about to be abducted by providing information about travel restraining orders and other preventative measures. While not holding itself out as a legal advisor, in the provision of this type of practical assistance the group offers quasi-legal support to parents who may not be able to afford legal advice or may have run into dead-ends in their cases. In this way, it represents an important extension of the legal process.

While CRN Japan has a strong advocacy and legal focus, other groups such as Left Behind Parents Japan, formed via a social networking portal (Meetup. com), are more social, encouraging parents to join and co-operate with one another. Left Behind Parents Japan was started by a Japanese citizen, Masako Akeo, herself a left-behind parent after her Japanese husband abducted their child from their home in Canada (Akeo 2010). The group arranges social functions in Tokyo, as well as events to lobby for changes to the law in Japan. At last count in May 2016, the group had 163 members.

There are also groups who publish their sites in Japanese, such as Chību kyōdōshinken hōseika undō no kai (中部共同親権法制化運動の会; Chubu Joint Custody Association for Legislating of Joint Custody and Joint Nurture), and Kyōdōshinken undō nettowāku (共同親権運動ネットワーク) or K-netto (Kネッ ト), which translates as 'Joint Custody Action Network (K-net)' (Chübu 2016; Kyōdōshinken n.d.). Compared to the Japan Children's Rights Network and similar groups with sites in English (and presumably a large member base of non-Japanese parents), these groups focus on advocating for change to domestic custody laws and local law reform activity, rather than detailing individual cases. This could be due to the fact that sole custody and minimal visitation are accepted as the social norm in Japan and reflected in the extant 
legal system, and case studies are therefore not effective tools in advocating for change. Nevertheless, these sites also represent an attempt to intervene in the social and legal status quo with respect to the child custody system in Japan, of which the Hague Abduction Convention is only one part.

In addition to social media groups, the online activities of individual leftbehind parents and their supporters can also provide an outlet for advocacy and support. Christopher Savoie is a regular user of Twitter (https://twitter. com/cjsavoie) and uses his account to post articles in English and Japanese about parental child abduction. He also uses it to convey messages to his children and ex-wife in Japan (although whether they ever see them is unknown). Then there are some more lateral approaches to the use of social media in parental child abduction cases. For example, a Twitter account in the name of Ashleigh Mojica Laws, (https://twitter.com/ashleighmojica), aged 1, appeared just a few months after her Filipina mother failed to return her to the United Kingdom after a holiday to the Philippines (Evening Chronicle 2011; Laws 2011). The Japanese connection to this case involved an allegation made by Ashleigh's father that her mother had been encouraged to abduct the child by a Japanese friend, as per the "Japanese playbook" on abduction (The Japan Children's Rights Network, n.d.[b]). Ashleigh is described in her Twitter profile as a "victim of international parental child abduction". The activity on the account was short-lived, but the creation of a social media account in the name of a baby who has no autonomy could be an attempt to garner sympathy for her father, either by himself or by a third party on his behalf.

The public forums provided by sites such as The Japan Children's Rights Network website provide a mechanism for left-behind parents to tell their stories and act as a conduit for information between left-behind parents and their children. They also have a coercive effect on the parent retaining the child; that is, they provide a kind of virtual bargaining chip for left-behind parents. By posting stories of parental child abduction and pictures of abducted children and their abducting parent, these sites act as an extra-legal form of pressure on abducting parents. The Japan Children's Rights Network details international and domestic abduction cases in which the abducting parent has contacted the organisation to request that information be removed, and where contact has been restored between the left-behind parent and their child on condition that the information is removed from the site (The Japan Children's Rights Network n.d.[d]). The very nature of these cases means there is a lack of identifying details. This is a clear example of the power of social media to-wrongly or rightly-name and shame, and feeds into its use as a type of virtual scarlet letter. Such usage has come to academic (e.g., Solove 2007) and popular (e.g., Ronson 2015) attention in recent years.

While those parents and supporters advocating for change to the way parental abduction is handled in Japan are clearly visible in social media, there are other individuals and groups who advise caution in changing Japan's approach to custody disputes. Some groups in opposition to Japan joining the Hague Abduction Convention took to social media prior to Japan eventually joining the treaty in 2014. One of these groups is the Safety Network for Guardians 
and Children (ハーグ条約加盟に反対する会), which set up its website in 2011 (Safety Network for Guardians and Children 2012). Another group of this kind is Hāgu 'ko no dasshu' jōyaku no hijun ni shinchō na kentō o motomeru shimin to hōritsuka no kai (ハーグ「子の奪取」条約の批准に慎重な検討を 求める市民と法律家の会; 'Association of Citizens and Lawyers Requesting Careful Consideration with Respect to the Ratification of the Hague 'Child Abduction' Convention') (Hāgu 2011). Both groups set out to register their concern regarding the signing of the Hague Abduction Convention by Japan, particularly with respect to the treatment of victims of family violence under the treaty. This concern echoes a large body of work in western legal theory which criticises the Hague Abduction Convention for not taking due account of the risks posed to abused spouses (e.g., Kaye 1999; Weiner 2004; Shetty and Edleson 2005).

Individual parents who have abducted their children have also used social media to tell their stories and explain their actions. Mika Yamashita is a Japanese citizen who started a blog under the name 'Marinko' in 2008 about her marriage to an Australian man in Australia, and their divorce and subsequent protracted custody dispute over their three daughters under Australian law. ${ }^{8}$ She ultimately abducted the children from Australia to Japan in February 2009. Her blog was eventually published as a book in Japan in 2010 (私が誘拐犯になるまで; 'I was Driven to Abduction') (Yamashita 2010). On the blog, and eventually in her book, Yamashita writes of her feelings of isolation while in Australia, her ex-husband's abusive and threatening behaviour and her frustration with the Australian legal process. Importantly, she also writes of her shock at the concept of shared parental authority under Australian law which meant she was essentially tied her to ex-husband until the children reached adulthood (Yamashita 2010, 59).

The staking out of moral territory on the internet by groups and individuals on both sides of the issue highlights the complexity of this social, legal and political problem and the careful attention required when analysing social media sites with respect to this sensitive issue.

\section{The Significance of the Use of Social Media in Parental Child Abduction Cases}

The use of social media in these cases is important for a number of reasons. Firstly, it provides a common thread for left-behind parents to communicate with each other. While some left-behind parents have the capacity to attract mainstream media attention to their cases, the overwhelming majority (should they wish to) do not, but the chances that they have access to some form of social media are far greater. ${ }^{9}$ In this way, social media is a leveller and community builder. It also creates a virtual support group for disparate parents whose paths may not have otherwise crossed due to restrictions on time and travel. 
Secondly, social media is important in these cases due to their dynamic nature. While a left-behind parent may have exhausted their legal options, their story does not end there. Many will feel compelled to keep agitating for their cause and looking to reach out to their lost children. Social media is a vital mechanism for documenting these ongoing stories. This idea was eloquently summed up by Scottish left-behind parent Douglas Galbraith, whose two sons were abducted from the United Kingdom to Japan by his Japanese wife. Douglas, an author, wrote a book entitled My Son, My Son: How One Generation Hurts the Next [2013] about his experience of the abduction, and likened his book to a "message in a bottle" to his children (Ross 2012, par. 6). Being unable to communicate with his sons, he felt his book was one way of potentially completing a "wide blank" in their lives at a later date and possibly correcting other versions of the story they may have been told by their mother (Ross 2012, par. 6). Not everyone has the resources and abilities to pen a publishable commercial manuscript, but social media allows most parents to try to fill the "wide blank" left by abduction for their children. The use of social media sites, including genealogy websites, has resulted in a "staggering number" of reunions between parents and children after years apart in abduction cases worldwide (Dabbagh 2012, 140).

The idea of social media providing a virtual "message in a bottle" proved true in the dramatic case of Chris Gulbraa. In August 2006 at the age of 15, Chris returned to his American father, Michael Gulbraa, in Utah after being taken to Japan from his home by his Japanese mother, Etsuko Tanizaki Allred, five years earlier (Brown 2006). Chris and his brother, also named Michael, were abducted to Japan by their mother on 28 November 2001. The couple had been divorced for several years prior to that time and Etsuko had custody of the children. The elder Michael had taken out a temporary restraining order requiring the children to remain in Utah after becoming concerned for their safety in the care of Etsuko's new husband (Brown 2006). The order was still in place at the time of the abduction (Gulbraa 2009). The father was awarded custody of the boys in April 2002 (Brown 2006). Chris claims that after he had been taken to Japan, his mother discouraged him from contacting his father, but he was given a mobile telephone after he turned 15 , which he used to send text messages to his father. On the last day of the summer holidays in 2006, Chris took a train from Kasugai to Osaka, where he went to the U.S. Embassy and was provided with documents allowing him to return to the United States, which had been arranged in advance by his father (Brown 2006). The case was heavily documented by the Japan Children's Rights Network website and other internet sites. In particular, the Japan Children's Rights Network site provided the father with a space to provide a detailed account of his story, accompanying which he posted a large number of legal documents regarding the custody of his sons (The Japan Children's Rights Network n.d.[c]). While the father was reluctant to disclose the precise details of how Chris was recovered to the United States, he reported that the internet documentation played a significant role in the recovery (The Japan Children's Rights Network n.d.[d]). 


\section{DIVISIONS WITHIN DIVISIONS: JAPANESE FAMILY LAW}

As noted in the introduction to this article, custody laws in Japan are being outpaced by changes in society arising from the creation and dissolution of international families, and social media is utilised by concerned parties as a way of bridging the gap. In this section, I examine the legal framework in Japan that forms much of the background and the impetus for this social media activity.

Japanese family law is contained in Book 4 ("Relatives") and Book 5 ("Inheritance") of the Civil Code (民法). While the family law provisions of Japan's Civil Code are predominantly modelled on French law, the historical legal system known as ritsuryō (律令) in Japan, which has its roots in Chinese legalism and Confucian ideals, has also been highly influential in the Japanese understanding of the function of law (Mizuno 2014, 254). Under the ritsuryo system, the law's function is to facilitate administrative policy, rather than to delineate the limits of authority; that is, it provides a less-prescriptive system of law than is seen in the west, which limits the rights and obligations that may be imposed on citizens (Mizuno 2014, 254). In family law, the ritsuryō concept may be seen in the ability of citizens to execute personal changes in status administratively, most notably through the family registration system, known as the koseki seido (戸籍制度) (Mizuno 2014, 259). ${ }^{10}$

While the overall marriage rate in Japan has declined and the age of marriage has risen in Japan since the 1970s (Ministry of Health, Labor and Welfare 2015, Table 9.1; Piotrowski et al. 2015, 1042), Japan remains a society in which formal legal or de jure marriage is the norm. De facto unions are still rare (Piotrowski et al. 2015, 1042) and the rate of births out of wedlock is extremely low, representing only $2.3 \%$ of the total of live births in Japan in 2014 (Ministry of Health, Labor and Welfare n.d., 33). The rate of births outside wedlock was similar in South Korea for 2014 (1.9\%), but very low compared to $40.3 \%$ in the United States in the same year (Ministry of Health, Labor and Welfare n.d., 33). The rate in the Philippines was also much higher than Japan in the same period, at 50.3\% (Philippines Statistics Authority 2016).

Japanese family law imposes divisions after family breakdowns that often exclude the parent who does not reside with the child. Japanese and nonJapanese parents alike have struggled with the constraints of the Japanese family law when trying to regain contact with their children and establish custodial and visitation arrangements after their children have been taken by the other parent. These constraints relate most prominently to the absolute nature of parental authority after divorce and the conceptualisation of visitation under Japanese law, both of which are discussed in detail below.

Japanese law does not recognise the concept of shared parental authority. Under its Civil Code, both parents are deemed to have shinken (親権; parental authority) over a child of the marriage until divorce, at which point it requires that either one parent or the other be designated parental authority (art. 819). 
Shinken includes the power to make decisions about the child's care, education and place of residence, as well as to represent the child in a legal sense, such as entering into contracts on the child's behalf (arts. 820, 821 and 824). From this broad pool of shinken powers, it is possible to separate physical custody, called kangoken (看護権), which encompasses the power to make decisions regarding the child's care, residence and education, from legal custody (still called shinken in this more limited, residual sense), which entails the power to enter into contracts, manage inheritances and dispose of real property in the child's name. In this way, upon divorce each parent can be vested with one of these two types of custodial authority (Bengoshi höjin 2014, 174). Even so, actual cases where custody is split in this way are rare in Japan. According to the Annual Report of Judicial Statistics (司法統計年報) compiled by the Supreme Court of Japan, out of the 18,246 cases in which the mother was allocated shinken by way of mediation or judgement in 2014, only 36 cases also involved a designation of kangoken to the father (Supreme Court of Japan $2014,43)$. Out of the 2,002 cases in which the father was allocated shinken that year, only 122 also involved a designation of kangoken to the mother (Supreme Court of Japan 2014, 43). The mechanism of splitting kangoken from the broader pool of shinken powers may be regarded as a function of pre-war law, under which it was sometimes considered appropriate to allow mothers to continue to physically provide care for children after divorce, even though there was a preference for granting legal custody to fathers and continuing the formal patrilineal relationship (Jones 2007, 216).

The Japanese system of family law, which designates sole parental authority to one parent or the other upon divorce, can be viewed as intrinsically tied to the koseki seido (family registration system). The koseki seido is historically linked to the 'household system', or ie seido (家制度), which is characterised by stemfamily relations and the value ascribed to lineage, and is widely considered to have its origins in feudal traditions and Confucian values of filial piety (see White 2002; Ronald and Alexy 2011). The koseki seido also plays a key role in defining one's self as Japanese. It was a precursor to the modern legal definition of nationality and was the sole mechanism of establishing legal status as Japanese until the introduction of the Nationality Law (国籍法) in 1899. Today, in the majority of cases it is not possible to establish Japanese nationality without a family record, or koseki (戸籍) (Chapman 2011). Noncitizens cannot register their own koseki. Japanese registrants tend to attach subjective meaning to their formal, administrative family as set out in their koseki, even where there may be a dislocation between the dynamics of the registered family and its social reality (Krogness 2011, 65). This attachment is an important consideration when analysing the issue of international parental child abduction in Japan from a social, political and legal perspective: children of Japanese citizens are viewed as belonging to a Japanese family's koseki, and the parent who retains shinken with respect to the child after divorce (whether inclusive of kangoken or not) retains the right to include the child in their koseki. This arguably creates a symbolic barrier to the idea of shared custody or custody by the non-Japanese spouse in the case of a breakdown in an international marriage. 
While the custom of the father taking custody after divorce continued up until the mid-1960s, there is now a well-entrenched maternal preference in child custody cases (Fuess 2004, 156-57; Costa 2010, 378). This reflects a transition from concern with patrilineal integrity to a focus on the 'best interests of the child'. Mothers were granted custody in $92.5 \%$ of cases handled by family courts in Japan in 2014 (Supreme Court 2014, 43); this figure is indicative of how custody has been awarded in divorce cases over the past 50 years, as the rate of paternal custody has not altered significantly during that time (Bengoshi Hōjin 2014, 177). This means it is fathers who most often lose all rights of custody upon divorce.

The predominance of sole custody in Japan brings the issue of visitation into stark relief. While some divorce handbooks ${ }^{11}$ published in Japan describe the non-custodial parent as having a “visitation right” (面接交渉権) (e.g., Baba Sawada 2008, 61; Hiruta 2012, 92; Hiruta 2014, 106), whether the concept holds any legal weight has been a matter of debate for many years (Jones 2007, 240-45; Kojima 2011, 90-102; Tsuneoka 2013, 57-58). In any event, Japanese statute does not explicitly recognise visitation as a legal right (Jones 2007, 228-29). From 1 April 2012, an amendment to Article 766 of the Civil Code took effect which requires couples divorcing by kyogi rikon to state their agreement on visitation and other contact, child support payments and other matters concerning the care of the child on their divorce application. This amendment represents the first time that post-divorce visitation or other interaction between a child and their non-custodial parent has been referred to in Japanese statute (Jones 2011b). Its effect has been limited, however, as failure to comply with the requirements set out in Article 766 does not attract any penalty, nor is it a barrier to obtaining a divorce (Hiruta 2014, 106). The non-government organisation Kizuna Child-Parent Reunion reports that compliance with Article 766 is as low as 50\% (Kitagawa 2014). Separately, in March 2013, the Japanese Supreme Court found that a court could impose a fine on a custodial parent who failed to facilitate visitation when required to do so by a court order or arbitrated decision. ${ }^{12}$ The fine for this kind of case is relatively small: JPY50,000 (approximately AU\$500) (Supreme Court of Japan 2013). While this may be a sign of progress for non-custodial parents involved in the small percentage of mediated and adjudicated cases, it is nonetheless only an indirect form of enforcement of visitation determinations, and noncompliant parents may simply pay the fine as a form of 'efficient breach' (Goetz and Scott 1977) to maintain distance from the other parent.

Accordingly, for the majority of parents without shinken, the law effectively prevents them from having a major presence in their children's lives; they become an "optional part" of their family (Jones 2007, 221). This plays out in reality as a so-called 'clean break', where a child and their custodial parent

\footnotetext{
11 Divorce handbooks are self-help guides that are generally written by lawyers or legal scholars for popular consumption and sold in major bookshops. They typically contain basic explanations of laws relating to divorce, asset division and custody, practical information regarding the divorce process, advice on post-divorce life and information regarding the impact of divorce on the parties' koseki. Example titles of these types of handbooks are ‘Easy to Understand! Divorce Procedure and Process’ [よくわかる! 離婚の手続きとすすめ方] (Hiruta 2012) and 'Life's Legal Issues Series: I Want to Ask a Lawyer! Divorce and Children Issues Q\&A' [暮らしの法律問題シ リーズ 弁護士にききたい! 離婚と子どもの問題] (Baba Sawada 2008).

12 In Japanese, the case name is Kansetsu kyōsei ni taisuru shikkō kōkoku kikyaku kettei ni taisuru kyoka kōkoku jiken (間接強制に対する執行抗告棄却決定に対する許可抗告事件), which translates as 'Permitted Appeal of the Dismissal of an Appeal for the Execution of Indirect Enforcement.'
} 
have no contact with the non-resident parent. While this is certainly not a rule, it is a kind of social norm in Japan and stands in marked contrast to the family law systems of many other countries around the world in which the concepts of shared parental authority and the nurturing of the parent-child bond in the event of a family breakdown have emerged as vital tenets. These countries include some of Japan's treaty partners under the Hague Abduction Convention, such as the United States of America, Australia, the United Kingdom, Canada, the Scandinavian countries and Germany (see Rhoades 2002; Ryrstedt 2003; Tanase 2011). The concept of shared parental authority is, however, by no means universal, nor is it consistently applied (for further discussion see Blair and Weiner 2005).

The Japanese family law system, like many other family law systems around the world, ${ }^{13}$ places importance on maintaining the status quo of a child's living arrangements despite a family breakdown. Given the absolute nature of the custody law, it is critical for a parent wishing to be awarded custody under Japanese law to first establish a pattern of caring for the child (Bengoshi Hōjin 2014, 176-77). In combination with the maternal preference, the risk faced by fathers under the status quo preference is clear should the mother take the child. One divorce handbook even goes so far as to suggest that fathers ask their own parents to stay at the family home to watch the mother, and also advises them to speak to the staff at the child's childcare facility to warn them of the risk of abduction (Bengoshi Hōjin 2014, 177-79).

Until the ratification of the Hague Abduction Convention, custody orders issued outside Japan were not likely to assist a left-behind parent in navigating their way through the constraints of the Japanese legal system in the case of parental abduction. While Japanese courts can and have recognised foreign custody orders, ${ }^{14}$ they are often not enforced (Jones 2007, 256-57). This may be a reflection of the practical and logistical difficulties associated with enforcement of international custody orders, but it is also due to the lack of legal measures available against non-compliant parties and the reluctance of the police to become involved in domestic disputes (Jones 2007, 256-57). A preference for the status quo may also play a part. The effect is that even parents with full custody of their child under a foreign law may have little or no parenting authority under Japanese family law after their child has been taken to Japan by the other parent (Jones 2007, 256-57).

\footnotetext{
13 The likely effect of changing a child's circumstances is a factor to be considered alongside other factors by courts determining matters involving the upbringing of a child under UK family law (Children Act 1989, Section 1(3)(c)); for further discussion see Lowe and Douglas 2015, 409-10). A long-standing status quo arrangement is often a significant factor in custody determinations by state courts in the United States, for example in California (see Row 2015, $\$ 1.31$; Waller 2008, 108). In Australia, it is an "additional consideration" (as opposed to a "primary consideration") to which courts must have regard (The Family Law Act 1985; Section 60CC (3)(d); for further discussion see Rathus and Alexander 2014, 383-84). The status quo is a consideration in all of these jurisdictions, but its significance is consistently subject to the paramount consideration of the best interests (as expressed under Australian and Californian law) or welfare (as expressed under U.K. law) of the child. Japanese courts also apply a "best interests of the child" standard (see Jones 2007), highlighting the complex nature of this seemingly simple concept.

14 Japan's statute on conflict of laws or private international law rules, Hō no tekiyō ni kansuru tsūsoku hō (法 の適用に関する通則法; Act on the General Rules of Application of Laws), provides that the legal relationship between a parent and a child is to be determined by the child's national law where that is the same as the national law of either the father or mother's national law, or in all other cases by the law of the child's habitual residence (art. 32). The Act also provides that where a person has two or more nationalities, his or her national law shall be the country in which the person has habitual residence from among those states of which he or she has nationality, or if there is no such country, the law of the state with which he or she is most closely connected. Where one of those nationalities is Japanese, Japanese law shall be that person's national law (art. 38).
} 
These elements of the Japanese domestic law combine to create an environment in which some parents feel like they have no options but to turn to abduction. ${ }^{15}$ Very little incentive is provided under the law for custodial parents to encourage or facilitate contact with the non-resident parent. By disproportionately and absolutely favouring those parents with residence of their children, regardless of how those living arrangements came about, the Japanese legal system is open to being criticised for allowing custody disputes to become a "zero sum game” (Jones 2014) or a case of “whoever abducts first wins” (先に連れて行っ たもの勝ち) (Bengoshi Hōjin 2014, 177). In such an environment, it seems only natural that the 'losing' party will seek some form of redress through extralegal forums when their legal avenues have been exhausted.

\section{Engagement with International Law}

Until recently, the difficulties faced by left-behind parents within the Japanese legal system were compounded by the fact that Japan was not a party to the Hague Abduction Convention, which is the key mechanism at international law dealing with the issue of international parental child abduction. The Hague Abduction Convention calls for the restoration of the pre-abduction status of the child, with a view to having the issues of any substantive custody dispute determined by a court in the child's place of habitual residence in accordance with its local laws (art. 1). Habitual residence is a legal concept determined by reference to indicia such as shared parental intent and the experiences of the child up to the point of the abduction (see Vivatvaraphol 2009). Without the Hague Abduction Convention, and in the absence of any other international agreement on international child abduction, left-behind parents can only try to assert their right of custody through the domestic legal system of the country to which their child has been taken. For the reasons discussed above, left-behind parents of children residing in Japan have often faced insurmountable difficulties when trying to assert rights of custody, including visitation, under the domestic legal system.

The Hague Abduction Convention was first drafted by the Hague Conference on Private International Law on 24 October 1980 and put out for ratification over 30 years ago. All G7 nations, with the exception of Japan, had ratified the Hague Abduction Convention by 1995 (Hague Conference on Private International Law 2014). This omission on the part of Japan was widely reported in the English-language media both inside and outside of Japan (e.g., The Mainichi 2013; McCurry 2008; Sekine 2013). Japan's neighbours Thailand, Singapore, Russia and South Korea ratified the Hague Abduction Convention in 2002, 2010, 2011 and 2012 respectively (Hague Conference 2014). The Hague Abduction Convention also applies in the Special Administrative Regions of Hong Kong and Macau, entering into force there in 1997 and 1999 respectively (Hague Conference 2014). The People's Republic of China and the Philippines,

15 There are no statistics on the number of domestic parental child abductions in Japan. The Supreme Court of Japan acknowledges that a portion of the applications made in Japanese family courts each year for the handover (引渡し) of children are cases of parental abduction (Supreme Court of Japan 2005; see also Jones (2011a)). Jones notes that the hand-over disputes which reach court represent only a small number of the overall disputes each year (2011a, 51). In 2014, the Japanese family courts handled a total of 2,074 applications for the hand-over 
however, are not signatories to the Hague Abduction Convention which is of significance given the high number of marriages between nationals of Japan and these two countries.

In May 2011, the government of Japan announced its intention to join the Hague Abduction Convention, and signed and ratified the treaty on 24 January 2014. The Hague Abduction Convention entered into force in Japan on 1 April 2014, and legislation governing its implementation took effect the same day. ${ }^{16}$

\section{EMERGING TENSIONS IN JAPANESE CASES}

The Japanese Ministry of Foreign Affairs is considering the implementation of the Hague Abduction Convention a success so far, noting a drop in reported abductions between 2013 and 2014 (Masangkay 2015). While the signing of the treaty was a significant step towards legal, social and cultural change for Japan, some commentators have been subdued in their assessment of developments to date, including U.S. Congressman Christopher Smith, who is a vocal advocate for American left-behind parents and believes Japan has been too slow in responding to international abduction cases (Slavin 2015).

Japan returned its first child under the Hague Abduction Convention in October 2014. In that case, the boy's Japanese mother had taken the child to Japan from his home in Germany in June 2014 without the consent of his German father. After the father made an application for the return of the child under the Hague Abduction Convention, the Japanese Ministry of Foreign Affairs was able to mediate an agreement between the parties for the return of the child.

The much-anticipated first ruling by a Japanese Court with respect to a return application under the Hague Abduction Convention was made on 19 November 2014. The case involved a Japanese couple and their four-year-old daughter who had been living in Sri Lanka since February 2013. The mother had taken the child to Japan for a temporary visit in June 2014 and failed to return to Sri Lanka. The father's return application was heard by Chief Justice Shinichi Oshima of the Osaka Family Court, who ruled that the daughter be returned to Sri Lanka (Abe 2014). The mother appealed the ruling to the Osaka High Court but it upheld the lower court's decision on 30 January 2015 and the child returned to Sri Lanka in April 2015 (Ito 2015). In March 2015, the first application under the Hague Abduction Convention concerning an international union, that is one involving a non-Japanese parent, came for judicial ruling before a Japanese court. In that case, the Japanese mother had married the Turkish father in Turkey and had continued to live there after the birth of their child. The mother returned to Japan with the child in December 2014, prompting the father to make an application for the child's return under the Hague Abduction Convention. On 20 March 2015, the Tokyo 
Family Court ordered that the child be returned to Turkey (The Mainichi 2015). These rulings are historically and legally important as they represent the first rulings under the Hague Abduction Convention in Japanese courts, include an appellate court. They are also culturally and politically significant, as they demonstrate that the Hague Abduction Convention can be effectively implemented in Japan, and they could be construed as the first steps in dismantling its reputation as a "black hole" for parental abductions.

No official figures have been published by the Japanese government regarding the number of cases addressed since the Hague Abduction Convention was implemented, so it is difficult to make an objective assessment of its effectiveness so far. It does seem, however, that a major source of discontent for left-behind parents has arisen in the way that applications for visitation under the Hague Abduction Convention are managed by Japan. According to a report in The Japan Times, Japan received 86 applications for visitation under the Hague Abduction Convention from April 2014 to August 2015 (Kameda 2015). Of these, 67 were in relation to children removed to or retained in Japan (Kameda 2015). In response to applications for visitation, Japan announced it would implement a system of visitation via video conferencing to address applications for visitation under the Hague Abduction Convention (Kameda 2015). These video conferences would be monitored by an independent social worker who has the authority to intervene if they deem it necessary to do so (Kameda 2015). The Japanese branch of the Geneva-based non-governmental organisation International Social Service is contracted by Japan's Ministry of Foreign Affairs to provide the independent social workers to facilitate such visitation under the Hague Abduction Convention (International Social Service Japan, n.d.).

'Virtual visitation' is not a new concept. It has been ordered in child custody cases around the world since the late 1990s (Knoetze 2013) and it does seem a positive move towards the use of new media to link people in different countries. The use of an independent third-party monitor as standard, however, is a concept novel to Japan. While this is better than having no visitation at all, this type of limited and monitored contact is regarded as unnecessarily punitive and suggestive of wrongdoing by some left-behind parents (Masangkay 2015). Such critics have pointed out that supervised access is typically ordered in western legal systems in cases of family violence or where the visiting parent has problems with substance abuse or mental illness (Masangkay 2015). Its use in situations where abduction is a risk is, however, also well established in both western legal systems and in Japan (e.g. Pearson and Thoennes 2000; Hiruta 2012, 92; Kajimura 2013, 248-51). The tyranny of distance in international custody cases means that parents may have to adjust their understanding of what counts as a visit with their child and accept the assistance offered by technology. Nevertheless, the value of this type of access must be questioned when it does not promote genuine communication between the parent and the child and is not supplemented by physical meetings (see Doucet 2011). 
The issue with respect to virtual visitation may be seen as an extension of the existing problem of dislocation between the nature of visitation as it is understood in Japan and how it is recognised in many other countries. Visitation, when ordered or agreed upon in Japan, tends to be 'minimalist'; that is, of relatively short duration (no more than two or three hours) and limited in frequency (monthly or bimonthly), and in contentious cases may involve only a formal meeting at a designated family centre (Tanase 2011, 579-80). ${ }^{17}$ This virtual visitation issue is also indicative of the wider challenges faced by Japan in navigating the lingering tension between its domestic family law and the more liberal approaches to custody and visitation of many of the other Hague contracting states. ${ }^{18}$ This unresolved tension means that many left-behind parents are disappointed with the outcomes they receive through the legal options available to them. For many, social media provides an opportunity for the expression of this disappointment, and the search for solace and some form of resolution.

\section{CONCLUSION}

Social media platforms such as Skype and Facebook provide a readily accessible means of communication to support the honeymoon phase of new long-distance relationships, and help established families maintain ties across great distances and national borders. Social media can, however, also support and document the disruption of relationships. My examination of the use of social media in cases of parental child abduction can perhaps be seen in part as belonging to this flipside: it is technology acting to support the downside of international relationships.

In his fictional critique of social media networks, The Circle (2013), author Dave Eggers discusses the "communion" found by those publicly documenting their painful experiences. While the intense bereavement felt by left-behind parents at the loss of their relationships with their children cannot be understated, social media can have a positive effect in these cases by bringing people with common issues together and potentially allowing parents to reconnect with children who have been abducted or are otherwise lost in another country, even though it may be many years later. It is one manifestation of a "virtual community" (Castells 2001, 386-89) which has arisen from the greater distribution of communications technology for public use.

Japan is at an important moment in its family law history as it increases its connection to international family law through its implementation of the Hague Abduction Convention, as seen in the first cases heard under the treaty in Japan. The wider impact of these developments on Japan's domestic law, and its attitude to cases which do not fall under the Hague Abduction

\footnotetext{
17 In divorce cases determined in 2014 by family courts in Japan (by way of mediation or adjudication), weekly and fortnightly visitation was provided for in approximately $7.1 \%$ and $8.1 \%$ of cases respectively; monthly visitation was provided for in approximately $43.5 \%$ of cases; and overnight visitation was agreed upon or ordered in approximately $7.1 \%$ of cases (Supreme Court of Japan 2014, 43). 
Convention, is yet to be seen. For now, social media is used by individuals affected by international custody disputes to reach out to others and seek assistance, whether as a left-behind parent, an abducting parent or a parent concerned about the potential for abduction in the future. This is important in the case of abductions involving Japan, given the dislocation between its family law and the varying expectations held by parents involved in abduction cases as to the way the custody of their children ought to be managed. This dislocation is not limited to international cases, with Japanese parents also expressing disillusionment at the state of the law in Japan governing domestic custody cases. By connecting these groups, social media facilitates a subtle but substantive form of internationalised communications.

While much of the content produced and shared via social media may seem prosaic, in the case of international parental child abduction, it allows a disparate group of people with a specific and urgent issue to locate each other, subject to internet access around the world, and work together to share information, seek and provide support, and move toward solving their specific issues. In this way, social media helps to fill a void left by a legal system which has not yet adapted to meet the needs of a changing and internationalised form of family. It can provide a light for parents in an otherwise intractable situation. Whether social media will continue to play this role depends in large part on the way in which Japanese law and society responds to new conditions of the family in society.

\section{GLOSSARY}

chōtei (調停)

mediation

hikiwatashi (引渡し)

hand-over (of children to the legally recognised custodial parent)

ie seido (家制度)

household system, characterised by stem-family relations and the value ascribed to lineage, and widely considered to have its origins in feudal traditions and Confucian values of filial piety

\section{kangoken (監護権)}

physical custody

kokuseki hō (国籍法)

Nationality Law

koseki (戸籍)

family record

koseki seido (戸籍制度)

family registration system

divorce by consent 
mensetsu kōshōken (面接交渉権)

visitation right (lit., 'visitation negotiation right')

$\operatorname{minp} \bar{o}$ (民法)

Civil Code

ritsuryō (律令)

system of codification of criminal and administrative/civil law with origins in Chinese legalism and Confucian ideals

shinken (親権)

parental authority; also, legal custody (as opposed to physical custody)

shihō tōkei nenpō (司法統計年報)

Annual Report of Judicial Statistics compiled by the Supreme Court of Japan

\section{APPENDIX: LIST OF RELEVANT LAWS/TREATIES AND ADVOCACY GROUP WEBSITES}

\section{Laws/Treaties}

Act for Implementation of the Convention on the Civil Aspects of International Child Abduction [国際的な子の奪取の民事上の側面に関する条約の実施に関する法 律], act no. 48 of 2013

http://www.japaneselawtranslation.go.jp/law/detail/?id=2159\&vm $=04 \& \mathrm{re}=01$ (Japanese and provisional English translation)

Act on the General Rules of Application of Laws [法の適用に関する通則法], act no. 10 of 1898

http://law.e-gov.go.jp/htmldata/H18/H18HO078.html (Japanese)

https://sydney.edu.au/law/anjel/documents/ZJapanR/ZJapanR23/ZJapanR23_20B_ Okuda_Anderson_Translation.pdf. (English)

Civil Code (Japan) [民法], act no. 89 of 1896

http://www.moj.go.jp/content/000056024.pdf (Japanese and English)

Convention of 25 October 1980 on the Civil Aspects of International Child Abduction https://assets.hcch.net/docs/e86d9f72-dc8d-46f3-b3bf-e102911c8532.pdf

Nationality Law (Japan) [国籍法], act no. 147 of 1950

http://www.moj.go.jp/MINJI/kokusekiho.html (Japanese)

http://www.moj.go.jp/ENGLISH/information/tnl-01.html (English)

\section{Advocacy Group Websites}

Chūbu kyōdōshinken hōseika undō no kai [中部共同親権法制化運動の会]

Chubu Joint Custody Association for Legislating of Joint Custody and Joint Nurture http://chubu-kyoudousinken.com/

Hāgu jōyaku kamei ni hantaisuru kai [ハーグ条約加盟に反対する会] 
Hāgu 'ko no dasshu' jōyaku no hijun ni shinchō na kentō o motomeru shimin to hōritsuka no kai [ハーグ「子の奪取」条約の批准に慎重な検討を求める市民と法律家の会] Association of Citizens and Lawyers Requesting Careful Consideration with Respect to the Ratification of the Hague 'Child Abduction' Convention

http://hague-shincho.com/

Kyōdōshinken undō nettowāku [共同親権運動ネットワーク] or K-netto [Kネット]

'Joint Custody Action Network (K-net)'

http://kyodosinken.com/

Left Behind Parents Japan

http://www.meetup.com/Left-Behind-Parents-Japan/

The Japan Children's Rights Network (CRN Japan)

http://crnjapan.net/The_Japan_Childrens_Rights_Network/Welcome.html

\section{REFERENCES}

Abe, S. 2014. "Osaka Court Orders Return of Child to Sri Lanka under the Hague Treaty," The Asahi Shimbun (Asia \& Japan Watch), 20 November. Accessed 15 February, 2016. http://ajw.asahi.com/article/behind_news/social_affairs/AJ2 01411200052 .

Act on the General Rules of Application of Laws [法の適用に関する通則法], act no. 10 of 1898. English translation by K. Anderson and Y. Okuda. Accessed 19 May, 2016. https://sydney.edu.au/law/anjel/documents/ZJapanR/ ZJapanR23/ZJapanR23_20B_Okuda_Anderson_Translation.pdf.

Agopian, M. W. 1984. "The Impact on Children of Abduction by Parents." Child Welfare 63 (6): 511-19.

Akeo, M. 2010. "Point of View/Masako Akeo: Japanese Laws Should Encourage Joint Custody," The Asahi Shimbun, 23 June. Accessed 28 February, 2014. http:// www.asahi.com/English/TKY201006220385.html.

Åkerström, M. 2015. "Deliberation and Adjudication as Democratic Practice in Post-fact Society." In Strategic Communication, Social Media and Democracy: The Challenge of the Digital Naturals, edited by W. T. Coombs, J. Falkheimer, M. Heide and P. Young, 119-29. Oxford: Routledge.

Austin, M. 2013. "Rights and Obligations of Parents." Internet Encyclopaedia of Philosophy. Accessed 30 December, 2014. http://www.iep.utm.edu/parentri/.

Australian Bureau of Statistics. 2015. "Table 10, Children Aged 0-17 Years with a Natural Parent Living Elsewhere, Contact Arrangements by Age of Child 2012-2013, 2009-2010, 2006-2007," 4442.0-Family Characteristics and Transitions, Australia, 2012-2013. Accessed 14 February, 2016. http:// www.abs.gov.au/AUSSTATS/abs@.nsf/DetailsPage/4442.0201213 ?OpenDocument. 
Australians with Abducted Children. 2013. "About Us." Australians with Abducted Children. Accessed 24 June 2016. http://www.awac.asn.au/Australians_ With_Abducted_Children/About_Us.html.

Baba Sawada Hōritsu Jimusho [馬場・澤田事務所]. 2008. Kurashi no hōritsu mondai shiriizu Bengoshi ni kikitai! Rikon to kodomo no mondai QઐA [暮らしの] 法律問題シリーズ 弁護士にききたい! 離婚と子どもの問題Q\&A]. Tokyo:Chūō Keizaisha [中央経済社].

Bengoshi Hōjin Mai Taun Hōritsu Jimusho [弁護士法人マイタウン法律事務所]. 2014. Otoko no rikonjutsu, bengoshi ga oshieru 'katsutame' no rikon senryaku [男 の離婚術、弁護士が教える「勝つため」の離婚戦略]. Tokyo: Kōdansha [講談社].

Birmingham, L. 2011. "How Did Japan Become a Haven for Child Abductions?" Time, 7 March. Accessed 4 February, 2016. http://content.time.com/time/ world/article/0,8599,2056454,00.html.

Blair, D. M. and M. H. Weiner. 2005. "Resolving Parental Custody Disputes-A Comparative Exploration.” Family Law Quarterly 39 (2): 247-66.

Bodenheimer, B. M. 1977. "The International Kidnapping of Children: The United States Approach." Family Law Quarterly 11 (1): 83-100.

Bramham, D. 2013. "Japan is a Black Hole for Abducted Children," The Vancouver Sun, 17 August. Accessed 14 February, 2016. http://www.vancouversun. com/life/Daphne+Bramham+Japan+black+hole+abducted+childr en/8799583/story.html

Breaden, J. and C. S. Stevens. 2014. "Introduction: Internationalising Japan as a Discourse and Practice." In Internationalising Japan: Discourse and Practice, edited by J. Breaden, S. Steele and C. S. Stevens, 1-12. London: Routledge.

Brown, K. 2006. “International Dispute Splits Up Utah Family," The Salt Lake Tribune, 25 December. Accessed 24 October, 2015.http://www.sltrib.com/ci_4898084.

Buckland, K. 2006. “Think of the Children: Japan's Prejudiced Legal System Encourages Desperate Parents to Abduct their Own Kids." Metropolis Magazine, 27 January. Accessed 24 October, 2015. http://archive.metropolis. co.jp/tokyo/618/feature.asp.

Buerk, R. 2011. "Japan Custody Heartache for Foreign Fathers," BBC News, 6 February. Accessed 5 December, 2013. http://www.bbc.com/news/worldasia-pacific-12358440.

Castells, M. 2001. The Internet Galaxy: Reflections on the Internet, Business and Society. Oxford: Oxford University Press. http://dx.doi.org/10.1007/978-3322-89613-1

Chapman, D. 2011. "Geographies of Self and Other: Mapping Japan through the Koseki." The Asia-Pacific Journal: Japan Focus 9 (29). Accessed 19 May, 2016. http://apjjf.org/-David-Chapman/3565/article.pdf. 
Chūbu Kyōdōshinken Hōseika Undō no Kai [中部共同親権法制化運動の会]. 2016. Chūbu kyōdōshinken hōseika undō no kai, website. Accessed 14 February, 2016. http://chubu-kyoudousinken.com/.

Civil Code 1896 (Japan), act 89.

Costa, J. 2010. "If Japan Signs the Hague Convention on the Civil Aspects of International Child Abduction: Real Change or Political Maneuvering?" Oregon Review of International Law 12: 369-88.

Dabbagh, M. 2012. Parental Kidnapping in America: An Historical and Cultural Analysis. Jefferson: McFarland \& Company, Inc.

Dingle, S. 2011. "Japan Proves Safe Haven for Abducted Kids." 7.30 Report, television broadcast. Australian Broadcasting Corporation. Broadcast 7 September. http://www.abc.net.au/news/2011-09-07/japan-proves-safehaven-for-abducted-kids/2875758.

Doucet, C. 2011. “'See You on Skype!': Relocation, Access, and Virtual Parenting in the Digital Age." Canadian Journal of Family Law 27 (2): 298-50.

Eggers, D. 2013. The Circle. San Francisco: McSweeney's Publishing.

El Ouirdi, M., A. El Ouirdi, J. Segers, and E. Henderickx. 2014. "Social Media Conceptualization and Taxonomy: A Lasswellian Framework." Journal of Creative Communications 9 (2): 107-26. http://dx.doi.org/10.1177/097325 8614528608

Esin, C., M. Fathi and C. Squires. 2013. "Narrative Analysis: The Constructionist Approach." In The SAGE Handbook of Qualitative Data Analysis, edited by U. Flick, 203-16. London: Sage Publications Limited.

Evening Chronicle. 2011. "Dad's Pain after Filipino Partner Fled with Girl," Evening Chronicle, 5 July. Accessed 25 August, 2015. http://www.chroniclelive.co.uk/ news/north-east-news/dads-pain-after-filipino-partner-1401199.

The Family Law Act, 1975 (Australia), act 53.

Flyvbjerg, B. 2006. "Five Misunderstandings about Case-Study Research.” Qualitative Inquiry 12 (2): 219-45. http://dx.doi.org/10.1177/1077800405284363

Fuchs, C., K. Boersma, A. Albrechtslund, and M. Sandoval, eds. 2012. Internet and Surveillance: The Challenges of Web 2.0 and Social Media. New York: Routledge.

Fuess, H. 2004. Divorce in Japan: Family, Divorce and the State. Stanford: Stanford University Press.

Goetz, C. and R. Scott. 1977. "Liquidated Damages, Penalties, and the Just Compensation Principle: A Theory of Efficient Breach." Columbia Law Review 77: 554-94. http://dx.doi.org/10.2307/1121823

Goffman, E. 1959. The Presentation of Self in Everyday Life. Garden City, New York: Doubleday. 
Greif, G. L. and R. L. Hegar. 1993. When Parents Kidnap: The Families Behind the Headlines. New York: The Free Press.

Gulbraa, M. C. 2009. Statement (untitled) submitted to Tom Lantos Human Rights Commission Hearings on International Child Abduction, 2 December. Retrieved from Bring Abducted Children Home. Accessed 25 October, 2015. http://www.bachome.org/261/.

Hague Conference on Private International Law. 1980. "Convention on the Civil Aspects of International Child Abduction," 25 October. Recueil des Conventions: Collection of Conventions (1951-1996): 265-83.

2011. A Statistical Analysis of Applications made in 2008 under the Hague Convention of 25 October 1980 on the Civil Aspects of International Child Abduction, Part 1 Global Report. Accessed 12 February, 2016. https:/assets. hcch.net/upload/wop/abduct2011pd08ae.pdf.

. 2014. Status Table 28: Convention of 25 October 1980 on the Civil Aspects of International Child Abduction. Accessed 22 October, 2014. http://www. hcch.net/index_en.php?act=conventions.status\&cid=24.

Hāgu 'ko no dasshu' jōyaku no hijun ni shinchō na kentō o motomeru shimin to hōritsuka no kai [ハーグ「子の奪取」条約の批准に慎重な検討を求める市 民と法律家の会]. 2011. Hāgu 'ko no dasshu' jōyaku no hijun ni shinchō na kentō o motomeru shimin to hōritsuka no kai, website. Accessed 14 February, 2016. http://hague-shincho.com/.

Hargittai, E. 2007. "Whose Space? Difference among Users and Non-Users of Social Network Sites." Journal of Computer-Mediated Communication 13 (1): 27697. http://dx.doi.org/10.1111/j.1083-6101.2007.00396.x

Hiruta, K. [比留田 薰]. 2012. Yoku wakaru! Rikon no tetsuzuki to susumekata [よくわ かる! 離婚の手続きとす寸め方]. Tokyo: Shufu-no-tomo Sha [主婦の友社].

. 2014. "Rikon" no yasashii jiten: kiiwādo to yōgo de wakariyasuku kaisetsu [「離婚」のやさしい事典:キーワードと用語でわかりやすく解説]. Tokyo: Shufuno-tomo Sha [主婦の友社].

International Social Service Japan. n.d. “Contact/Visitation.” Accessed 19 May, 2016. http://www.issj.org/en/separation/contact-visitation.

Ito, M. 2015. "Girl's Return to Sri Lanka is First in Response to Hague Convention Court Order," The Japan Times, 15 April. Accessed 16 February, 2015. http:// www.japantimes.co.jp/news/2015/04/15/national/crime-legal/young-girlsent-back-sri-lanka-hague-convention/\#.VsGbTOYXV5V.

Jaffe, P. 2014. "A Presumption against Shared Parenting for Family Court Litigants." Family Court Review 52 (2): 187-92. http://dx.doi.org/10.1111/fcre.12081

The Japan Children's Rights Network. n.d.[a]. "About the Japan Children's Rights Network.” The Japan Children's Rights Network. Accessed 25 September, 2015. http://crnjapan.net/The_Japan_Childrens_Rights_Network/res-about.html. 
n.d.[b]. "Breaking News: Japanese Woman Assists Philippine Mother in Abducting her Child Using the "Japanese Playbook." The Japan Children's Rights Network. Accessed 5 December, 2013. http://www.crnjapan.net/The_ Japan_Childrens_Rights_Network/blg-anash.html.

. n.d.[c]. "'Etsuko has Ignored All Orders of the Court since October 2001...' Michael's Website." The Japan Children's Rights Network. Accessed 25 October, 2015.http://crnjapan.net/The_Japan_Childrens_Rights_Network/ per-mg.html.

. n.d.[d]. "Success Stories." The Japan Children's Rights Network. Accessed 25 October, 2015. http://crnjapan.net/The_Japan_Childrens_Rights_ Network/res-sucstore.html.

Jones, C. P. A. 2007. "In the Best Interests of the Court: What American Lawyers Need to Know about Child Custody and Visitation in Japan." Asian-Pacific Law \& Policy Journal 8: 167-69.

. 2011a. Kodomo no tsuresari mondai: nihon no shihō ga oyako o hikisaku [子どもの連れ去り問題 日本の司法が親子を引き裂く]. Tokyo: Heibonsha [平凡社].

.2011b. "Upcoming Legal Reforms: A Plus for Children or Plus Ça Change?" The Japan Times, 9 August. Accessed 1 August, 2013. http://www.japantimes. co.jp/community/2011/08/09/issues/upcoming-legal-reforms-a-plus-forchildren-or-plus-ca-change/.

. 2014. "Hague Jars with Japan's Family Law, a Zero-sum Game with Only One Outcome," The Japan Times, 16 April. Accessed 17 September, 2014. http://www.japantimes.co.jp/community/2014/04/16/issues/haguejars-with-japans-family-law-a-zero-sum-game-with-only-one-outcome/\#. VBlPjWMoVO8.

Joseph, S. 2012. "Social Media, Political Change, and Human Rights." Boston College International and Comparative Law Review 35 (1): 145-88.

Kajimura, T. 2013. Saibansho kara mita menkai kōryū chōtei, shinpan no jitsumu [裁判所から見た 面会交流調停・審判の実務]. Tokyo: Nihon Kajo Shuppan [日本加除出版].

Kameda, M. 2015. "Japan to Introduce Video Visitation System for Parents in CrossBorder Custody Disputes," The Japan Times, 28 August. Accessed 18 September, 2015. http://www.japantimes.co.jp/news/2015/08/28/national/ japan-introduce-video-visitation-system-parents-cross-border-custodydisputes/\#.ViYd4H1z9dw.

Kaye, M. 1999. "The Hague Convention and the Flight from Domestic Violence: How Women and Children are being Returned by Coach and Four." International Journal of Law, Policy and the Family 13 (2): 191-212. http:// dx.doi.org/10.1093/lawfam/13.2.191

Khondker, H. H. 2011. "Role of the New Media in the Arab Spring." Globalizations 8 (5): 675-79. http://dx.doi.org/10.1080/14747731.2011.621287 
Kitagawa, J. 2014. "Left Behind: Parents Challenge Japan's Dismal Child Abduction Laws.” Metropolis Magazine, 15 June. Accessed 30 December, 2014. http:// metropolis.co.jp/features/feature/left-behind/.

Knoetze, I. 2013. "Not So Far Apart: Virtual Visitation in Relocation Disputes." De Rebus 536: 24-25.

Kojima, I [小嶋 勇]. 2011. Hanarete mo kodomo ni aitai: hikihanasareta kodomo to no menkai kōryū o kangaeru tame ni [離れても子どもに会いたい:引き離され た子供との面会交流をかなえるために]. Tokyo: Seikatsu Shoin [生活書院].

Krogness, K. J. 2011. "The Ideal, the Deficient, and the Illogical Family: An Initial Typology of Administrative Household Units." In Home and Family in Japan: Continuity and Transformation, edited by R. Ronald and A. Alexy, 65-90. New York: Routledge.

Kyōdōshinken Undō Nettowāku [共同親権運動ネットワーク]. n.d. Kyōdōshinken undō nettowāku, website. Accessed 14 February, 2016. http://kyodosinken.com/.

Lah, K. 2009. "American Father in Custody Case Released from Japanese Jail," CNN. com, 15 October. Accessed 24 October, 2015. http://edition.cnn.com/2009/ WORLD/asiapcf/10/15/japan.custody.battle/index.html?eref=rss_ mostpopular.

Laws, A. 2011. "My Living Hell of Child Abduction," Dad's Justice Forum, 29 October. Accessed 25 August, 2015. http://dadsjustice.dadgallery.com/t89-my-livinghell-of-child-abduction.

Left Behind Parents Japan. n.d. "Left Behind Parents Japan-Home." Accessed 10 February, 2016. http://www.meetup.com/left-behind-parents-japan/.

Lowe, N. and G. Douglas. 2015. Bromley's Family Law, 11th ed. Oxford: Oxford University Press. http://dx.doi.org/10.1093/he/9780199580408.001.0001

The Mainichi. 2013. "Editorial: Gov't Must Support Japanese Nationals in Crossborder Custody Disputes," 20 February. Accessed 31 July, 2013. http:// mainichi.jp/english/english/perspectives/news/20130220p2a00m0na00 3000c.html.

. 2015. "Tokyo Family Court Orders Child to be Returned Overseas under Hague Convention," 25 March. Accessed 15 February, 2016. http://mainichi. jp/english/articles/20150325/p2a/00m/0na/012000c.

Manago, A. M., M. B. Graham, P. M. Greenfield, and G. Salimkhan. 2008. "Selfpresentation and Gender on MySpace." Journal of Applied Developmental Psychology 29 (6): 446-58. http://dx.doi.org/10.1016/j.appdev.2008.07.001

Masangkay, M. 2015. "Child Abductions Down in Year since Hague Pact but not All are Happy," The Japan Times, 2 April. Accessed 18 September, 2015. http://www.japantimes.co.jp/news/2015/04/02/national/child-abductionsyear-since-hague-pact-happy/\#.ViYfkX1z9dw. 
McCurry, J. 2008. "Family: Custody Battle in Japan Highlights Loophole in Child Abduction Cases," The Guardian, 15 September. Accessed 19 October, 2015. http://www.theguardian.com/world/2008/sep/15/japan.childprotection.

. 2013. "Japan no Longer Sanctions Child Abduction in Mixed-marriage Cases," The Christian Science Monitor, 22 May. Accessed 14 February, 2016. http://www.csmonitor.com/World/Asia-Pacific/2013/0522/Japan-nolonger-sanctions-child-abduction-in-mixed-marriage-cases.

McIntosh, J. 2009. "Legislating for Shared Parenting: Exploring some Underlying Assumptions.” Family Court Review 47 (3): 389-400. http://dx.doi.org/ 10.1111/j.1744-1617.2009.01263.x

Mégret, F. 2011. "International Human Rights Law Theory." In Research Handbook on the Theory and History of International Law, edited by A. Orakhelashvili, 199-231. Cheltenham: Edward Elgar Publishing Limited. http://dx.doi. org/10.4337/9780857933089.00016

Ministry of Health, Labor and Welfare of Japan. n.d. Vital Statistics in Japan-The Latest Trends. Accessed 19 May, 2016. http://www.mhlw.go.jp/english/ database/db-hw/dl/81-1a2en.pdf.

. 2014. Jinkō dōtai chōsa [人口動態調查]. Accessed 29 January, 2016. http:// www.mhlw.go.jp/toukei/list/81-1.html.

2015. Vital Statistics in Japan (Marriages). Accessed 15 February, 2016. http://www.e-stat.go.jp/SG1/estat/ListE.do?lid=000001137969.

Mizuno, N. 2014. "A Comparative Perspective on Japanese Family Law." In Transformation of the Public and the Intimate in Asian Modernity, edited by E. Ochiai and L. A. Hosoya, 254-65. Leiden: Koninklijke Brill NV.

Morozov, E. 2011. The Net Delusion: The Dark Side of Internet Freedom. New York: Public Affairs.

Pavlenko, A. 2007. "Autobiographic Narratives as Data in Applied Linguistics." Applied Linguistics 28 (2): 163-88. http://dx.doi.org/10.1093/applin/amm008

Pearson, J. and N. Thoennes. 2000. "Supervised Visitation: The Families and Their Experiences." Family Court Review 38 (1): 123-42. http://dx.doi. org/10.1111/j.174-1617.2000.tb00564.x

Philippines Statistics Authority. 2015. Live Births: Philippines 2014. Accessed 19 May, 2016. https://psa.gov.ph/content/live-births-philippines-2014.

Piotrowski, M., A. Kalleberg, and R. R. Rindfuss. 2015. "Contingent Work Rising: Implications for the Timing of Marriage in Japan." Journal of Marriage and Family 77 (5): 1039-56. http://dx.doi.org/10.1111/jomf.12224

Polkinghorne, D. E. 1995. "Narrative Configuration in Qualitative Analysis." International Journal of Qualitative Studies in Education 8 (1): 5-23. http:// dx.doi.org/10.1080/0951839950080103 
Postmes, T. 2007. "The Psychological Dimensions of Collective Action, Online." In The Oxford Handbook of Internet Psychology, edited by A. J. Joinson, K. Y. A. McKenna, T. Postmes and U. Reips, 165-84. Oxford: Oxford University Press.

Rathus, Z. and R. Alexander. 2014. "Goode and Goode-Judgment." In Australian Feminist Judgments: Righting and Rewriting Law, edited by H. Douglas, F. Bartlett, T. Luker and R. Hunter. Oxford: Hart Publishing Limited.

Rhoades, H. 2002. “The Rise and Rise of Shared Parenting Laws." Revue Canadienne de Droit Familial 19: 75-113.

Riessman, C. K. 2008. Narrative Methods for the Human Sciences. Thousand Oaks: Sage Publications, Inc.

Ronald, R. and A. Alexy. 2011. "Continuity and Change in Japanese Homes and Families." In Home and Family in Japan: Continuity and Transformation, edited by R. Ronald and A. Alexy, 165-84. New York: Routledge.

Ronson, J. 2015. So You've Been Publicly Shamed. New York: Penguin Group.

Ross, P. 2012. "Interview: Douglas Galbraith, Author of My Son, My Son," The Scotsman, 3 April. Accessed 25 September, 2015. http://www.scotsman. com/lifestyle/books/interview-douglas-galbraith-author-of-my-son-myson-1-2209815\#axzz3pBwV83aU.

Row, C. A. 2015. "Overview of Custody and Visitation Litigation". In California Child Custody and Litigation and Practice (April 2015 Update). Oakland: Continuing Education of the Bar.

Rubenstein, K. 2007. "Citizenship in an Age of Globalisation: The Cosmopolitan Citizen?" Law in Context 25 (1): 88-111.

Ryall, J. 2013. "Hopes Raised for British Parents Denied Access to Children in Japan," The Telegraph Online, 15 January. Accessed 24 October, 2015. http://www.telegraph.co.uk/news/worldnews/asia/japan/9803796/Hopesraised-for-British-parents-denied-access-to-children-in-Japan.html.

Ryrstedt, E. 2003. "Joint Decisions-A Presumptive or a Drawback in Joint Parental Responsibility?” Australian Journal of Family Law 17: 155-207.

Safety Network for Guardians and Children [ハーグ条約加盟に反対する会]. 2012. Safety Network for Guardians and Children, website. Accessed 14 February, 2016. http://hague-dv.org/.

Sagatun, I. J. and L. Barrett. 1990. "Parental Child Abduction: The Law, Family Dynamics, and Legal System Responses." Journal of Criminal Justice 18 (5): 433-442. http://dx.doi.org/10.1016/0047-2352(90)90058-J

Saltzman, S. R. 2009. "Christopher Savoie Follows Abducted Children to Japan, Gets Arrested," CBS News, 29 September. Accessed 30 December, 2014. http://www.cbsnews.com/news/christopher-savoie-follows-abductedchildren-to-japan-gets-arrested-photos/. 
Sekine, S. 2013. "Abe Intent on Child-custody Treaty, but Opposition Remains," The Asahi Shimbun AJW, 31 January. Accessed 25 February, 2013. http://ajw. asahi.com/article/behind_news/politics/AJ201301310089.

Shetty. S. and J. L. Edleson. 2005. "Adult Domestic Violence in cases of International Parental Child Abduction.” Violence against Women 11 (1): 115-38. http:// dx.doi.org/10.1177/1077801204271477

Slavin, E. 2015. “Congressman: Japan 'Breathtakingly Unresponsive' on US Child Abduction," Stars and Stripes, 27 March. Accessed 20 October, 2015. http:// www.stripes.com/news/congressman-japan-breathtakingly-unresponsiveon-us-child-abduction-1.336910.

Solove, D. 2007. The Future of Reputation: Gossip, Rumour, and Privacy on the Internet. New Haven: Yale University Press.

Squire, C., M. M. D. Davis, C. Esin, M. Andrews, B. Harrison, L. Hydén, M. Hydén. 2014. What is Narrative Research? London: Bloomsbury Academic.

Supreme Court of Japan [最高裁判所]. 2000. Shihō tōkei nenpō (kaji jiken hen) [司 法統計年報 (家事事件編) ]. Accessed 20 May, 2016. http://www.courts.go.jp/ app/sihotokei_jp/list?filter[type]=1\&filter[yYear]=2000\&filter[yCategory]= \&filter[mYear $]=\&$ filter$[\mathrm{mMonth}]=\&$ filter$[\mathrm{mCategory}]=$.

. 2005. Ko no hikiwatashi chōtei [子の引き渡し調停]. Accessed 10 June, 2016. http://www.courts.go.jp/saiban/syurui_kazi/kazi_07_09/index.html.

2011. Katei saibansho iinkaigijigaiyō [家庭裁判所委員会議事概要]. Accessed 14 February, 2016. http://www.courts.go.jp/tokyo-f/vcms_lf/111201kasaiiinkai gijiroku.pdf.

. 2014. Shihō tōkei nenpō (kaji jiken hen) [司法統計年報 (家事事件編)]. Accessed 20 May, 2016. http://www.courts.go.jp/app/sihotokei_jp/list?filter [type] $=1 \&$ filter[yYear] $=2016 \&$ filter[yCategory] $=3 \&$ filter $[\mathrm{mYear}]=\&$ filter $[\mathrm{m}$ Month] $=\&$ filter[mCategory] $=$.

Supreme Court of Japan (First Petty Bench) [最高裁判所第一小法廷]. 2013. Kansetsu kyōsei ni taisuru shikkō kōkoku kikyaku kettei ni taisuru kyoka kōkoku jiken [間接強制に対する執行抗告棄却決定に対する許可抗告事件]. Minshū [民集] 67 (3): 864.

Tanase, T. 2011. "Divorce and the Best Interests of the Child: Disputes over Visitation and the Japanese Family Courts." Pacific Rim Law \& Policy Journal 20 (3): $563-88$.

Terr, L. C. 1983. "Child Snatching: A NewEpidemic of an Ancient Malady." The Journal of Pediatrics 103 (1): 151-56. http://dx.doi.org/10.1016/S0022-3476(83) 80804-X

Toland, P. 2011.“Left-behind Parents Waiting," The Japan Times, 27 July. Accessed 30 December, 2014. http://www.japantimes.co.jp/opinion/2011/07/27/ commentary/left-behind-parents-waiting/. 
Tsuneoka, F. [常岡 史子], ed. 2013. Hajimete no kazokuhō [はじめての家族法], 2nd edition. Tokyo: Seibundō [成文堂].

U.S. Department of State. 2013. "Japan and International Child Abduction." Travel. State.Gov. Accessed 1 March, 2013; site now unavailable. http://travel.state. gov/abduction/country/country_5899.html.

U.S. Embassy in Japan. 2010. "Rapid Increase in Child Abductions to Japan." American View, 22 January. Accessed 11 October, 2015. http://amview.japan. usembassy.gov/wordpress/rapid-increase-in-child-abductions-to-japan/.

Vaulerin, A. 2013. "Le Japon Devrait Ratifier la Convention sur les Enlèvements d'Enfants," Libération, 22 February. Accessed 2 March, 2013.http://www. liberation.fr/monde/2013/02/22/le-japon-devrait-ratifier-la-convention-surles-enlevements-d-enfants_883961.

Vivatvaraphol, T. 2009. "Back to Basics: Determining a Child's Habitual Residence in International Child Abduction Cases Under the Hague Convention." Fordham Law Review 77 (6): 3325-69.

Waller, M. W. 2008. California Family Law for Paralegals, 5th ed. New York: Aspen Publishers.

Warner, R. W. 2010. "International Child Custody and Abduction under the Hague Convention." New York State Bar Association International Law Practicum 23 (Spring ): 50-54.

Weiner, M. H. 2004. "Strengthening Article 20." University of San Francisco Law Review 38 (4): 701-46.

White, M. I. 2002. Perfectly Japanese: Making Families in an Era of Upheaval. Berkeley: University of California Press. http://dx.doi.org/10.1525/ california/9780520217546.001.0001

Willacy, M. 2012. "Sayonara Baby." Foreign Correspondent, television broadcast. Australian Broadcasting Corporation. Broadcast 22 May. http://www.abc. net.au/foreign/content/2012/s3508549.htm.

The World Bank. 2016. Internet Users (per 100 People). Accessed 10 February, 2016. http://data.worldbank.org/indicator/IT.NET.USER.P2.

Yamashita, M. 2010. Watashi ga yūkaihan ni naru made [私が誘拐犯になるまで]. Tokyo: Taitoru [タイトル]. 


\section{The Cultural Semantics of the Japanese Emotion Terms 'Haji' and 'Hazukashii'}

\section{GIAN MARCO FARESE}

Australian National University
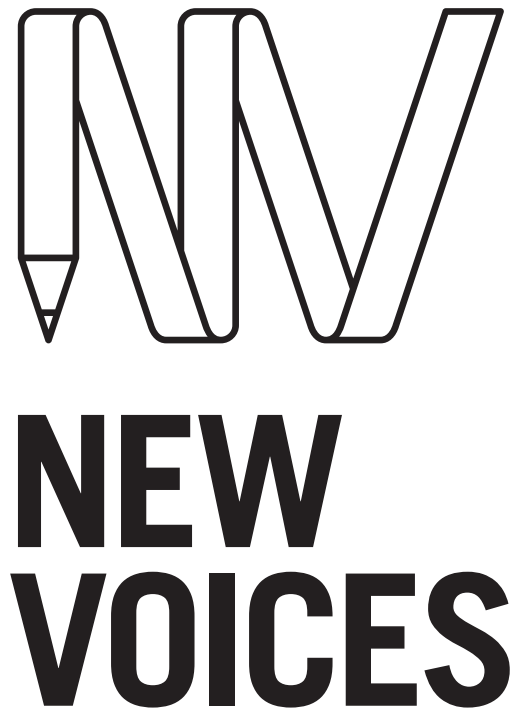

IN JAPANESE STUDIES

\section{ABSTRACT}

This paper presents a cultural semantic analysis of the Japanese emotion terms 'haji' and 'hazukashii', made using the methodology of the Natural Semantic Metalanguage (NSM). The paper has three aims: (i) to pinpoint the conceptions of 'haji' and 'hazukashii' as emotion terms in Japanese language and culture; (ii) to highlight the differences in meaning with their typical English translations 'shame' and 'embarrassing', and show that 'haji' and 'hazukashii' reflect two different, culture-specific emotion conceptions; (iii) to emphasise the suitability of NSM for cross-cultural comparisons of emotion terms in different languages and, in turn, for cross-cultural training. The examples adduced are taken from various sources, including a Japanese dictionary, the Kotonoha corpus of Japanese language and Japanese novels.

\section{KEYWORDS}

Natural Semantic Metalanguage; cross-cultural differences; haji; hazukashii; literature; shame; embarrassment; emotion terms; linguistics; social and cultural identity; translation

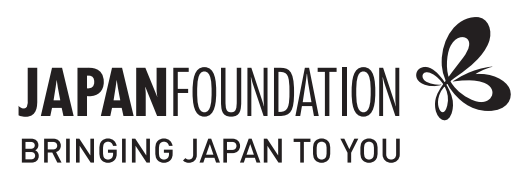

To link to this article:

http://dx.doi.org/10.21159/nvjs.08.02

ISSN 2205-3166

New Voices in Japanese Studies is an interdisciplinary, peer-reviewed journal showcasing the work of emerging scholars from Australia and New Zealand with research interests in Japan.

All articles can be downloaded free at $\underline{\text { newvoices.org.au }}$

(c) The Japan Foundation, Sydney and Gian Marco Farese, 2016

\section{(c) (1) () $\odot$}

This work is licensed under a Creative Commons Attribution-NonCommercialNoDerivatives 4.0 International License. 


\section{INTRODUCTION}

For researchers interested in investigating the relationship between language and culture, the study of emotion terms presents, in my view, both opportunities and challenges. By studying emotion terms, a researcher has the opportunity to lay bare the cultural assumptions underlying emotional expression in a particular society and highlight the differences with other societies. Once the differences are identified, the challenge lies, as I see it, in describing them in terms which are both recognisable as indigenous by the speakers of the investigated languages and understandable by people outside the specific linguaculture being studied. Regrettably, it is often the case in discussions on emotions that English emotion terms are used on the mistaken assumption that they are cross-culturally applicable.

In order to compare how speakers of different languages conceive emotions, it is necessary to compare the meanings of the words they use to express what they feel. Very often, differences in the meaning of apparently similar emotion terms reflect culturally and even socially specific emotion conceptions, as well as differences in the cultural salience of a given feeling. One such case is that of the Japanese emotion terms 'haji' (耽) and 'hazukashii' (恥ずかし (), the objects of the present study. This paper shows that these words denote two different feelings which are salient to Japanese speakers and in Japanese society, and that their meanings differ with respect to the cognitive scenario associated with each feeling. Using the methodology of the Natural Semantic Metalanguage (henceforth NSM, introduced in Section 3), the differences in meaning between these words can be captured clearly using single semantic components phrased in simple and cross-translatable words.

At the same time, this paper highlights the differences in meaning and cultural salience between these two Japanese words and their typical English translations, 'shame' and 'embarrassing'. As will be illustrated in Sections 4 and 5, 'haji' is usually rendered as 'shame' (or 'ashamed') and 'hazukashii' as 'embarrassing'. For the purpose of encouraging greater accuracy in translation, I will show that 'haji' and 'hazukashii' are different in meaning from 'shame' and 'embarrassing' and that they reflect emotion conceptions specific to Japanese language and cultural contexts.

Another point I will make is that emotion terms in English cannot be used as culturally neutral conceptual reference points to describe feelings as conceived in languages other than English. The approach taken to the present analysis draws on Wierzbicka's (2006; 2014) ideas that English words-including English emotion terms-reflect the views of a specific linguacultural world (which Wierzbicka generalises as "Anglo culture") ${ }^{1}$ and therefore cannot be used as a culturally neutral means of translating elements of other cultural worlds. Wierzbicka contends that a truly non-ethnocentric analysis phrased in culturally neutral terms is possible if a suitable methodology is adopted. This perspective informs the basis of NSM, the methodology employed in the present study. Crucially, the aim of this study is not to understand the Japanese conception of 'shame' and 'embarrassing' as intended in English, 
but the Japanese conception of 'haji' and 'hazukashii', which are semantically different terms that, I argue, cannot be accurately translated in English as 'shame' and 'embarrassing'. Ultimately, this paper will show that NSM is an optimal tool for elucidating and comparing the meanings of emotion terms in different languages.

I will analyse a number of situations in different novels in original Japanese and English translation in which people feel 'haji' or experience a 'hazukashii' feeling. Some other examples are taken from the Kotonoha corpus of Japanese and from the Goo Jisho online dictionary of Japanese.

\section{EMOTION CONCEPTIONS ACROSS LANGUAGES}

In his study on amae (甘え; roughly, 'emotional dependence'), Japanese psychologist Takeo Doi (1974) discussed the differences in how Japanese and English speakers express their emotions, putting particular emphasis on the role of language. He pointed out that "the typical psychology of a given nation can be learned only through familiarity with its native language" $(1974,15)$. In other words, to understand how emotions are conceived and expressed in a linguacultural world, one has to start from the words which people in that world generally use to express what they feel.

Doi's point relates to comparative studies conducted by various scholars in psychology and linguistics which show that emotions are expressed and conceived differently in different cultures, and that language is a determinant factor in this. Lutz's (1985) cross-cultural study on depression, for example, highlighted a number of important differences between the English word 'depression' and the word 'fago', used by the Ifaluk people of Micronesia.

First of all, in the modern scientific frame the contemporary English word 'depression' tends to denote a bad feeling that may be caused by an abnormal mental state. Typical characteristics of the 'depressed' person are self-reproach and "the failure to engage in the pursuit of happiness or the love of self that is considered to be the basic and normal goal of persons" (Lutz 1985, 70). For the Ifaluk, the indigenous community that maintains its customary traditions on the island of Yap in the Micronesian chain, the word 'fago' denotes a bad feeling resulting from the loss of a relationship with someone, either because this person has died or is away. The real concern in 'fago' is the impossibility of replacing the lost relationship. Furthermore, despite denoting a bad feeling, 'fago' is positively evaluated; in Lutz's words, "to assert one's fago is to implicitly claim to be a good person" $(1985,85)$.

Another difference between these emotion terms concerns how the bad feeling is overcome. In the world of modern industrialised medicine, the depressed person may be helped by a therapist and, increasingly, prescription drugs, but in the end it is expected that individuals develop the skills to overcome or cope with the feeling by themselves. In the Ifaluk world, by contrast, people give emotional advice to someone who has lost a loved person and encourage them 
to "stay around other people so as not to dwell on the loss" (Lutz 1985, 71). Clearly, 'fago' is not the same as 'depression', and their contexts differ. In her study, Lutz has stressed the difficulty of finding an exact equivalent in English for 'fago'; she glossed 'fago' as 'compassion/love/sadness', suggesting that the term could be rendered in English as one of these three words depending on the context. But she also specified that 'this is not the hypo-emotion of 'sadness', or the purely joyful 'love' of peers. It is 'sad love', 'sadness for the other"' (1985, 85). As I will discuss in the next sections, it is more accurate to say that the meaning of 'fago' contains semantic components which are also part of the meaning of the English terms 'sadness', 'love' and 'compassion'. However, the Ifaluk term has its own discrete meaning relative to its community of users and has no single equivalent word in English. Lutz concluded that 'depression' is not a universal feeling "because the conceptual equivalent to depression does not exist" in all languages $(1985,85)$, even though apparently similar emotional conceptions like 'fago' may be described in different languages.

Similarly, Ye's (2014) study has emphasised the differences between the Chinese 'xingfu' and its typical English translation, 'happiness'. Ye has suggested that the term 'happiness' denotes a good feeling related to some positive external circumstances and to the possibility of doing certain things as one wishes. In other words, one feels something good when good things are happening as one wants, and when because of this one can do things as one wants.

The Chinese 'xingfu', too, denotes a good feeling, but the cognitive scenario associated with it is substantially different from that associated with 'happiness'. Essentially, 'xingfü' expresses a good feeling originating from the "belief that one is cared for and loved" $(2014,201)$. It has to do with one's interpersonal relationships in that it arises from the possibility of enjoying the company of the people one loves, like family and partners. Ye explains that xingfü also derives from what the related people have done for the experiencer. In Ye's words, 'xingfu' implies "certain expectations of what the other party does for one. Only when those expectations are met can the experiencer be described as truly being in the state of xingfü" $(2014,203)$. According to Ye, "English does not appear to have words matching xingfù in meaning" $(2014,203)$.

The premise of these comparative studies of emotion terms and their English translations is that a systematic semantic study of the words which speakers of a given language use to express what they feel can be useful for multiple purposes. First, they can elucidate the emotional conceptions of the speakers of that language. Second, they highlight the salience of particular feelings for these speakers. Third, they can be used to compare different emotional conceptions, thereby highlighting the semantic differences between emotion terms typically used as translations for one another.

One emotional sphere which lends itself well to this kind of contrastive analysis is that of shame and embarrassment, especially if one wishes to compare different linguistic conceptions of these two feelings derived from Western and Eastern traditions. The Japanese cultural world is one in which shame and embarrassment are considered as fundamental feelings, as various 
scholars have pointed out (Benedict 1946; De Mente 2004; Sakuta 1967). This paper pinpoints the conception of the feelings denoted by the Japanese terms 'haji' and 'hazukashii', presenting two NSM-based semantic explications of their meanings.

\section{INTRODUCING NSM}

NSM is a reduced language based on a set of sixty-five semantic primes intended to represent the irreducible semantic core shared by all languages. Despite having different realisations and different morpho-syntactic properties in different languages, the primes appear to be lexicalised in all sampled languages (see Wierzbicka 1996; Goddard 2008, 2011; Goddard and Wierzbicka 1994, 2002, 2014). The lexical exponents of the primes represent the mini-lexicon of NSM, which is presented in its English and Japanese exponents in the Appendix.

NSM primes can be combined to form canonical syntactic constructions which appear to be available in all sampled languages and represent, therefore, a universal grammar. For example, the available evidence suggests that all languages allow the canonical clauses 'I feel something good' and 'someone feels something bad' (Wierzbicka 1999; Goddard and Wierzbicka 2014).

The mini-language and syntax of NSM are used to formulate semantic explications for the meaning of words. NSM explications can consist of one or more lines, with single lines being referred to as 'semantic components'. Despite being very limited in vocabulary and grammar, NSM explications offer four main advantages over dictionary definitions and other methods of semantic analysis. First, being phrased only in simple terms, they are intuitively clear. Second, they exclude the risk of circularity. ${ }^{2}$ Third, because the terms are available in all languages, the explications are directly cross-translatable and hence free from any terminological ethnocentrism. Fourth, the possibility of reading an explication in one's native language fosters an insider's perspective, which can be particularly useful for cross-cultural training.

This methodology has proven particularly suitable for analysing the relationship between the meaning of words, including emotion terms, and the cultural reality in which they are embedded. NSM-based studies on emotion terms have highlighted fundamental differences in emotion conceptions across linguacultures which had not been identified in previous non-NSMbased studies of the same phenomena (Asano-Cavanagh 2002, 2014; Goddard and Ye 2014; Hasada 2003, 2006; Wierzbicka 1999; Ye 2006).

In this paper, two semantic explications are proposed: one for 'haji' and one for 'hazukashii'. I contend that the explications capture not only the meaning, but also the cultural aspects of these terms. 


\section{SEMANTIC ANALYSIS OF HAJI}

In this section, the key components of the meaning of haji are discussed. They have been identified by analysing expressions and collocations in which this emotion term occurs, as well as various situations in novels in which different characters experience this feeling.

\subsection{The Fear That People Can Know Some Personal Bad Things}

The range of expressions and collocations in which haji occurs suggests that a fundamental component of its meaning is, in NSM terms, "someone feels something bad because this someone thinks like this: 'people can know something very bad about me"'.

The collocation 'haji o kaku' (恥をかく), for example, expresses the idea of 'being humiliated':

1) 公衆の面前で恥をかかされる [to be humiliated in public] (Goo Jisho, n.d.[a])

The use of "public" in this sample phrase suggests that humiliation implies that people have come to know some bad things about someone. Similarly, the expressions 'hajisarashi' (恥さらし) and 'uchi no haji o soto ni sarasu' (内の恥 を外にさらす), which literally mean 'to expose one's haji to other people', also suggest a bad feeling associated with the fear that some personal bad things can be publicly known.

There are various bad things about a person which can attract people's criticism and cause feelings of haji. Novels have proven to be a useful source of data, as different situations are portrayed in different stories. Two modern novels, in particular, offer some excellent examples: one is Yama no oto [1954] by Nobel Prize winner Yasunari Kawabata, and the other is Kinkakuji [1956] by Yukio Mishima. The protagonists of each novel are very different from one another in terms of age, social position and life experiences; therefore, the situations in which each feels haji are different and offer fruitful comparisons.

In his masterpiece Yama no oto, Kawabata portrays different scenarios in which the protagonist Shingō and other characters feel haji for different reasons. One case is when Shingō's daughter-in-law Kikuko talks about her birth, and reveals that her mother had felt haji for having had a child at her age:

2) 菊子の生まれたのは、もういらないし、もう出来ないと、思いこんだ後 で、母もこの年でと恥、自分の体を呪ったほどで、陏胎をこころみたがし くじった。

She had been born at a time when her mother no longer wanted children or thought herself capable of having them. Indeed, her mother had felt rather ashamed, at her age, and had considered abortion. ${ }^{4}$ 
Interestingly, the original Japanese text says that Kikuko tried to have an abortion but failed, whereas the English translation only says that she "considered" it. Because of this, the situation in Japanese reads as more extreme than it does in English and reveals more information about the situation than does the English translation.

Another case is when Shingös daughter Fusako and her husband divorce. When Shingō asks Fusako if she wishes to attack her ex-husband for having sent a divorce notice, she replies to him vehemently:

3)お父さまは、自分の娘を、なんだと思ってるの?いくじなし。自分の をこんなめにあわせて、腹も立てられないんですか? 小父さまが迎えに 行って、恥をさらして来るといいわ。

How do you feel about your daughter, Father? You coward. Seeing your daughter into this, and not upset, not the least little bit. Swallow your pride and go for him yourself.

Note that "pride" in the English translation is in fact "haji" in the original text, occurring in the aforementioned collocation 'haji o sarasu'. This example is significant because the person experiencing haji is a member of a group (a family) and the bad things about her affect the rest of the group, too. This is an important component of the meaning of haji which will be further discussed in Section 4.3.

Different situations are portrayed in Mishima's novel Kinkakuji, in which the author tells the story of a young priest who burnt down the famous Temple of the Golden Pavilion in Kyoto in 1950. In one case, the protagonist's feeling of haji results from the fear that people can witness his disgrace:

4) 寝ても覚めても、私は有為子の死を祆がった。私の恥の立会人が、消え 去ってくれることを初がった。証人さえいなかったら、地上から恥は根絶 されるだろう。他人はみんな証人だ。それなのに、他人がいなければ、恥 というものは生れて来ない。

Day and night I wished for Uiko's death. I wished that the witness of my disgrace would disappear. If only no witnesses remained, my disgrace would be eradicated from the face of the earth. Other people are all witnesses. If no other people existed, shame could never be born in the world. ${ }^{5}$

In another case, the protagonist feels haji for two different reasons: his impotence and his deformity. Interestingly, he distinguishes different degrees of haji, considering one worse than the other:

5）彼女の体はまばゆいばかり美しかった。しかし俺は不能だったのであ る。……俺は恥じていたが、内䧽足であることの恥に比べれば、どんな 恥も言うに足りなかった。

She offered me her body, and I may say that it was a dazzlingly beautiful body. But I was completely impotent when it came to the point. [...] I was ashamed 
In the above extracts, the protagonists feel haji because of their personal failures and shortcomings. Considering the protagonists' quite strong reactions to the feelings experienced (one tries to abort but fails, another one emphasises his disgrace and even distinguishes between worse and less worse haji), it seems plausible to hypothesise that they consider the personal things which they do not want people to know as not just 'bad', but 'very bad'.

Moreover, they seem to be even more scared of the consequences of public disclosure-that is, people's negative evaluation and retribution for their actions - than the 'very bad things' themselves. In other words, they seem to be very concerned about their public reputation and its associated impact on their lives. Therefore, in generating an NSM explication of haji, it is necessary to complement the thought 'people can know some very bad things about me' with an additional component: 'because of this, they can't not think something very bad about me'.

Evidently, haji is related to the key cultural concept of tatemae (建前), one's public behaviour, as opposed to the other key cultural concept of honne (本 音), one's real intentions and feelings (Ikeno and Davies 2002). Considering this apparently overwhelming concern for one's public reputation, one could assume that haji also plays a role in people's behaviour, in that someone may decide not to do something to avoid being discredited and feeling bad. This cultural aspect of the meaning of haji is discussed in the next section.

\subsection{Haji as Behavioural Restraint}

As De Mente (2004) writes, "while Christians, Muslims and others relied more on the threat of damnation and punishment by a vengeful god and powerful clergy, ... the Japanese resorted to shame as their primary psychological sanction to keep people in line" (112). The behaviour of a person in Japan is regulated by social mores developed over time in Japanese society and is not evaluated solely or even primarily in terms of Western (and Christian) ethical concepts of good and bad. Any behaviour which is not socially attuned to these mores tends to be condemned by other people and become a source of haji. In order to avoid experiencing this feeling, people may restrain their behaviour.

This seems to be the assumption underlying the adjectives 'muchi' (無知; 'with no idea of haji') and 'hajishirazu' (恥知らず; 'someone who does not know what haji is'), which are used to talk about someone who is not conscious (or does not care) that their behaviour can attract people's negative opinions. The following examples from the Kotonoha corpus of Japanese (2009) containing 'hajishirazu' suggest that if one knew the feeling of haji, one would avoid doing something: 
6) 天才を前にしてつたない英語で話すと、なんとまた恥知らずなことをし たのであろう。

And things like speaking in such poor English in front of a genius, that was probably another example of extremely hajishirazu behaviour.

7）君の瞳の色が気になっただなんて口に出して言えるほど、僕は恥知らず ではなかった。

I wasn't hajishirazu enough to say that I was impressed with the colour of your eyes.

In (6), the hajishirazu behaviour is the display of one's incompetence or lack of knowledge in front of a more expert person, whereas in (7) it is crossing the boundary between the private (one's thoughts) and the public (speech).

The apparent influence of haji on an individual's behaviour has been mentioned by Doi in relation to the sense of responsibility for public incidents in Japan. Doi explains that when a public incident occurs it is often the case that all the people connected to the incident resign, even if it is not actually their own responsibility. He writes that "in such cases the sense of solidarity with the group to which one belongs takes precedence over true responsibility" (1974, 56; see Gluck 2009 for a more detailed discussion of the concept of sekinin (責 任; 'responsibility') in Japanese culture). Significantly, Doi suggests that people in Japan tend to resign because of their sense of haji and not because of a sense of guilt, as could be the case in linguacultures rooted in monotheistic values.

In sum, the expressions and examples analysed so far give clues not only to the meaning of haji as an emotion term, but also to its cultural salience. If the hypothesis that haji can function as a behavioural restraint is seriously considered, then it seems plausible to suggest that haji is a culturally salient emotion in Japanese society (although not necessarily unique to it), and would suggest the need for English translations that reflected this.

\subsection{The Relation to the Group}

The other important component of the meaning of haji emerging from the extracts is the transmission of the bad feeling experienced by an individual to the group of people to which the individual belongs.

In example (3), presented in Section 4.1, Fusako's divorce affects the whole family. Fusako herself argues with her father and insists that he do something to save her from disgrace. Likewise, in another novel by Yukio Mishima, Haru no yuki [1971], Marquis Matsugae feels haji for the humble origins of his family. He wants to save his son Kiyoaki from experiencing the same feeling, so he sends him to the house of a nobleman to be educated: 
8）武家でこそあれ、父侯爵が、幕末にはまだ卑しかった家柄を恥じて、嫡 子の清顕を、幼時、公卿の家へ預けたりしなかったら、おそらく清は、 そういう心柄の青年には育っていなかったろうと思われる。

It was an old samurai family, but Kiyoaki's father, Marquis Matsugae, embarrassed by the humble position his forebears had occupied as recently as the end of the shogunate fifty years before, had sent the boy, still a very small child, to be brought up in the household of a court nobleman. ${ }^{6}$

As well as revealing a socially specific cause for haji, this example suggests that the feeling of haji can transcend generations, as it can be felt because of some bad things done by members of one's group in the past. The generational transfer of haji is also inherent in the expression 'shi ni haji' (死に恥じ; lit., 'haji in death'). This phrase stresses the importance of having an opportunity to redeem oneself from haji before death if at all possible, otherwise the dishonour will be transmitted to one's descendants.

The transmission of haji from one to all members of a group has been discussed by Lebra in terms of 'shame'. Lebra (2007) has pointed out that the collective sharing of 'shame' is institutionalised in Japan and that all members of the society are affected by it:

Shame feelings are not confined to the particular individual who has committed a shameful action or who is the target of ridicule. His shame is vicariously experienced by others who share the same status, because what is shamed is not an individual but the status itself. Status is derived from two sources, i.e, from membership in a group and from the state of belonging in a social category. Shame is therefore shared by Ego either when the shamed person is looked upon as a representative of the group of which Ego is a member or when the shamed person belongs to the same social category as Ego does.

$(2007,20)$

Lebra's point, in turn, is related to the more general cultural value of 'membership in a group', which is paramount in Japanese society. The importance of shüdan ishiki (集団意識; 'group consciousness') has been emphasised by Ikeno and Davies:

In Japanese society, people are primarily group-oriented and give more priority to group harmony than to individuals. Most Japanese consider it an important virtue to adhere to the values of the groups to which they belong. [...] In Japan, group members create their own social codes of behaviour, and group consciousness has become the foundation of Japanese society.

$(2002,195)$

The authors' point is an important one, as they explain that in Japan an individual's actions and occurrences not only affect themselves, but also have implications for the whole group to which they belong. De Mente has pointed out that a person committing a bad action is likely to be ostracised from the group, and once this happens it can be very difficult to become part of new

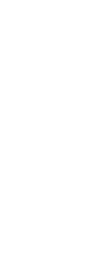

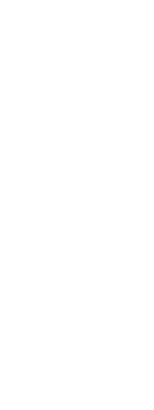


groups $(2004,112)$. This is exactly what happens to the protagonist of the novel Colourless Tsukuru Tazaki and His Years of Pilgrimage by Haruki Murakami [2014]. Tsukuru is believed to have raped one of the girls in a group of which he was once part, and for this he is excluded forever by his fellows. Entire chapters of the novel are centred on Tsukuru's depression and desire to die after his exclusion (Murakami 2014).

The risk of being responsible for bringing haji upon the group due to one's actions, therefore, can be seen as another component of the thought provoking the bad feeling. That is, someone feels something bad because they fear that some other people will feel the same and that the consequences visited by the group upon the individual will be painful. This component can be expressed in NSM terms as 'some people can feel something bad like I feel. In the next section, the proposed semantic explication for haji is presented in its entirety.

\subsection{Semantic Explication of Haji}

The following semantic explication captures the features of the meaning of haji identified in the analysis:

\section{someone $X$ feels haji}

someone $X$ feels something bad, because this someone $X$ thinks like this:

"people can know something very bad about me they can't not think something very bad about me because of this some people can feel something bad like I feel because of this this is bad"

The first two components of this explication follow the template used for other NSM explications of emotion terms (Wierzbicka 1999; Goddard and Ye 2014) and capture the idea that haji is a bad feeling associated with a particular way of thinking. The cognitive scenario contains a number of components, the most important capturing the idea that one's very bad behaviour (or occurrences that one is associated with) can make some people-those belonging to one's group-feel haji. As a consequence, these people will then either seek to distance themselves from the person or will suffer similar consequences. Not only is this a crucial difference from the English 'shame', to be explicated in Section 6, but it also captures the idea of haji as behavioural deterrent.

\section{SEMANTIC ANALYSIS OF HAZUKASHII}

In this section, the meaning of the emotion term 'hazukashii' is discussed. In this case, too, the semantic components proposed are based on an analysis of various situations and behaviours which are considered hazukashii, and of the reactions of people experiencing this feeling. 


\subsection{The Fear of People's Bad Thinking}

Like 'haji', the term 'hazukashii' denotes a bad feeling which someone experiences in a given situation. There is evidence suggesting that, like 'haji', 'hazukashii' is used in relation to personal bad things which one does not want other people to know or see. The following sample sentence from the Goo Jisho online dictionary suggest that the subjects feel something bad because of their personal weaknesses, and this state is described as 'hazukashii':

9)字が下手で恥ずかしい。[That I'm not good at characters is hazukashii.]

(Goo Jisho, n.d.[b])

In Yama no oto, Shingōs son Shūichi has a wife and a lover who are both pregnant. When Shingō asks his daughter-in-law Kikuko if she knew about the lover's baby, she replies that she did not and that had she known it she would not have talked about it because it would have been too hazukashii:

10)「先月だったね。子供の話しをしたのは……あの時は、もうわかって いたんだろう。」菊子は枕の上でかぶりを振った。「あの時は、わかり ませんでしたわ。わかっていたら、子供のことなんか、恥ずかしくて言 えませんわ。」

"It was last month, wasn't it, that we talked about a baby? I suppose you already knew." Kikuko shook her head. "No. If I had known, I would have been too embarrassed to say anything."

A similar situation is portrayed in the novel Kitchin [1988] by Banana Yoshimoto. In the following extract, the protagonist Mikage thinks that to have broken into tears in front of other people on a bus is hazukashii:

11）自分の機能はこわれたかと思った。ものすごく酔っぱらっている時みた いに、自分に関係ないところで、あれよあれよと涙がこぼれてくるの だ。次に私は恥ずかしさで真っ赤になっていた。それは自分でもわかっ た。あわてて私はバスを降りた。

Am I losing my mind? I wondered. It was like being falling-down drunk: my body was independent of me. Before I knew it, tears were flooding out. I felt myself turning bright red with embarrassment and got off the bus. ${ }^{7}$

In this case, the bad thing about the protagonist which she does not want other people to notice is her incapability of controlling her feelings. It is significant that Yoshimoto here highlights the physical symptoms (blushing) caused by the feeling.

Different examples, however, illustrate that what generates the bad feeling is not personal bad things which other people can know, but things done by other people. In Kitchin, Mikage thinks that it is hazukashii that her friend Hiiragi, a boy, is wearing a sailor suit, the school uniform worn by girls in Japan: 
12）待ち合わせたデパートの四階の喫茶店に、学校帰りの柊は、セーラー服 でやってきた。私は本当はとても恥ずかしかったが、彼があまり普通に 店に入ってきたので平静を装った。

Hiiragi and I had arranged to meet, after he got out of school, in a coffee shop on the fourth floor of a department store. In he came, wearing a sailor-style girl's high school uniform, complete with middy blouse and skirt. The truth is I was mortified, but he acted so natural that I managed to feign calmness.

In another case, Mikage experiences a hazukashii feeling because she is worried that her mother might have said something awkward about her to her friend on the phone:

13）きっと、母親が何か言ったのだろう、と私は思って恥ずかしかった。

My mother must have said something to him. I was embarrassed.

There are even examples of situations considered as hazukashii which are not negative at all, like being excessively praised in public. When Mikage and her friend say out loud how delicious their food is in a shop, she is aware that the staff must think their praise is hazukashii:

14）「異様においしい。」私は言った。.....「ない!」柊が言った。「うん。おいし い。生きててよかったと思うくらいおいしい。」私が言った。あんまりほめたの で、店の人がカウンターの向こうで恥ずかしそうにするくらいおいしかった。

"It's amazing how good this is" [...] . "Isn't it?" said Hiiragi. "Yes, it's delicious. So delicious it makes me grateful I'm alive," I said. So delicious I was moved to praise extravagant enough to make the counter person blush.

As pointed out by De Mente, excessive public praise is very hazukashii for a Japanese person, because it means to stand out from other people. He writes that "singling individual Japanese out for special praise in front of their coworkers often results in envy and ill-will, damaging morale and efficiency" $(2004,113) .^{8}$

Another example of a non-negative situation causing a hazukashii feeling is found in Yoshimoto's autobiographical essay Jinsei no tabi o yuku (2006), when the author and her friend put some chocolate in the letterbox of the boy she liked on St. Valentine's day:

15) 私が恥ずかしがっていたら、佐久間さんは「大丈夫だよ!名前も書いていない もん!」と言って、彼の家のポストまでついてきてくれた。

I thought it was hazukashii, but Sakuma told me, "Don't worry! Your name's not written on it!" and accompanied me to the letterbox of his house. 
Considering all these extracts, it can be concluded that the bad feeling of hazukashii is generated by the fear that people can think something bad about a person doing something that is outside normative behaviour modalitiesin these cases, strange or immodest actions. This contrasts with haji, which is generated by the fear that people can know some personal bad things. In fact, in most of the examples of hazukashii examined above, there are no personal bad things which people can know. Rather, the key element is that the experiencer does not want to develop a reputation as someone who does certain things, because they expect they will suffer negative consequences. This thought can be captured with two semantic components: one, if people know this, they can think something bad about me', and two, 'I don't want this'. Significantly, the phrasing of the first component is different from the phrasing of the explication for haji in that people's negative judgement is taken as a possibility ('people can think'), not as the inevitable consequence of the public disclosure of one's bad things ('people can't not think'). Furthermore, the component does not state that there is something 'bad' which people can know.

However, the two proposed components, 'if people know this, they can think something bad about me' and 'I don't want this', capture only part of the cognitive scenario provoking the hazukashii feeling. There is another component in the meaning of this term to be discussed in the next section.

\subsection{Relation to the Social Evaluation of Behaviour}

The fear of people's negative judgement of oneself is also related to the fact that in a society, there are both explicit and tacit rules of behaviour guided by specific cultural values. The examples analysed so far suggest that a hazukashii situation is always considered bad, even without being inherently negative (as in the case of public praise), and is likely to attract criticism. More importantly, the protagonists of the novels who find themselves in a hazukashii situation seem to know well that such situations are not in line with the social and/or ethical code and seem to agree with people's bad thinking about them, or at least understand what the consequences will be for their actions.

In (14), Mikage knows well that she should not have made such overt praise of the food in front of the counter person, and so loudly. In another part of the novel, she herself thinks that her friend Sōtarō's speaking in a loud voice is annoying and very hazukashii:

16）「ええっ!うそだろう!っ」宗太郎は大声で言った。彼のこの陰気な素直さを私 は昔、本気で愛していたが、今はうるさいのですごく恥ずかしいだけだった。

"What?! Don’t lie to me!" Sōtarō said in a loud voice. In the old days I loved him for his frankness, but right now it struck me as obnoxious, and I was only mortified.

The fact that Mikage herself considers Sōtarōs attitude as urusai (うるさい; loud and annoying) suggests that she, too, thinks that to speak in a loud voice 
is bad, so she would not be surprised if people thought something bad about her because of her friend. Arguably, the same applies to the other situations which she considers hazukashii, for example her male friend wearing a sailor suit.

If one also considers the behaviour of the people in the examples analysed, this hypothesis becomes even more plausible. In (10), Kikuko explicitly says that even if she had known about the lover's baby before, she would not have talked about it. In (11), Mikage gets off the bus so that people cannot see her cry. The protagonists' efforts to avoid people thinking something bad about them due to the hazukashii situation they find themselves in suggest that they are aware that such situations are considered bad by other people. Taking these elements into account, another semantic component can be posited for the cognitive scenario generating the bad feeling: 'if I think about it, I can't not think the same'.

In this and in the previous section, I have discussed the key features of the meaning of hazukashii; in the next subsection I will present the complete semantic explication.

\title{
5.3 Semantic Explication of Hazukashii
}

Because hazukashii is syntactically an adjective, the explication has to be related to a prototypical situation with which a particular way of thinking and a bad feeling are associated. Essentially, the following explication portrays the emotional reaction that someone can have thinking about a typically hazukashii situation:

\author{
(e.g. that my results are bad is) hazukashii \\ when something like this happens to someone, \\ this someone can think about it like this: \\ "if people know this, they can think something bad about me \\ when I think about this, I can't not think the same \\ I don't want this" \\ when this someone thinks like this, this someone can feel something bad, \\ like people can feel at many times when they think like this about something
}

Both this explication and that proposed for haji try to pinpoint two different emotion conceptions from the perspective of Japanese speakers. As will be discussed in the next section, these conceptions are culturally specific and differ from the feelings evoked in the English translations of these terms. These examples illustrate that apparently similar emotion terms of different languages can actually be semantically different: while some semantic components may be shared, other components are likely to be specific to the meaning of one term only. 


\section{COMPARING 'HAJI' AND 'HAZUKASHII' WITH THE ENGLISH 'SHAME' AND 'EMBARRASSING'}

In her analysis of 'shame' and 'embarrassment' (as the nominal form of 'embarrassing'), Wierzbicka (1999) has shown that these two concepts represent two different feelings for an English speaker, highlighting in particular howin Wierzbicka's conception of modern Anglo culture-'embarrassment' has expanded at the expense of 'shame'.

Wierzbicka has emphasised the difference between the current meaning of 'shame' and its meaning in Shakespeare's time. In Shakespeare's language, 'shame' was similar in meaning to 'chastity' and was considered a necessary, positive value. It also used to be associated with blushing. ${ }^{9}$ In its current meaning, by contrast, 'shame' always carries a negative connotation (Wierzbicka 1999, 110-11).

A key component of the meaning of 'shame' in contemporary English, as identified by Wierzbicka, is a person's concern that people can know some bad things about him/her, and that because of this people will think something bad about him/her. The personal bad things can be bad actions or behaviours, weaknesses or shortcomings, or even something bad about one's family origins. This component represents an important difference between the current and the former meaning of 'shame', for which Wierzbicka proposes the additional semantic component, 'I don't want other people to know something bad about me'.

The semantic explication proposed by Wierzbicka for the current meaning of shame is the following:

\section{$X$ feels shame \\ $X$ feels something bad because $X$ thinks like this: "people can know something bad about me they can't not think something bad about me because of this when I think about it, I can't not think the same"}


does not presuppose that there are some bad things which people can know. At the same time, the component also captures the idea that an individual's actions can be constrained by the fear of people's negative evaluation. In this respect, Wierzbicka has suggested that in the old sense, 'shame'

reflected a social climate in which other people's view of the individual was expected to act as a powerful means of control: it was expected that people wouldn't do certain things because they wouldn't want other people to know and to think bad things about them.

$(1999,111)$

According to Wierzbicka, modern English-speaking countries are not social and cultural environments where people's negative evaluation of a person can affect their public behaviour; therefore, in its current sense 'shame' is not about this:

The modern meaning of shame, however, does not reflect a kind of society where "other people's" anticipated view of us can be expected to act as a powerful regulator of our behaviour. In the modern Anglo society-as reflected in the mirror of semantics-other expectations and other concerns have come to the fore, as reflected, in particular, in the rise of the concept of embarrassment in modern English.

$(1999,111)$

As for 'embarrassment', Wierzbicka has suggested that this is typically associated either with a breach of social conventions or when unexpected bad things happen to someone (for example, one's stomach producing noises, trousers splitting in public, or being praised in front of other people). Furthermore, in Wierzbicka's view one does not have to be the actor of the action, but can feel something bad when other people break conventions. Significantly, the same situations are not causes of 'shame'.

Wierzbicka has also stressed that embarrassment often requires the physical presence of other people witnessing that something is happening to someone. To be seen, however, is not always necessary for a person to feel embarrassed. The most important component of the meaning of 'embarrassment' is a person's fear that people will think about him/her in a way that this person does not want to be thought about. This feature is captured by Wierzbicka with the component 'I don't want people to think about me like this'.

The complete explication for 'embarrassment' proposed by Wierzbicka is the following:

\section{$X$ feels embarrassment \\ $X$ feels something bad because $X$ thinks like this: "something is happening to me now not because I want it someone knows it this someone is thinking about me in one way because of this I don't want people to think about me like this"}


The idea that people come to know something about a person which could make them think about this person in a way which he/she does not want to be thought about is shared with the meaning of hazukashii. However, an important difference between the two terms lies in the expected way of thinking. In the case of 'hazukashii', it is expected that people will think something bad about a person; whereas, in the case of 'embarrassment', people's perception of the person is not expected to be necessarily bad, but simply different from how one would want to be thought about in that specific situation.

The semantic differences between 'haji' and 'shame', and between 'hazukashii' and 'embarrassment' imply (i) that English and Japanese speakers experience different feelings when using these terms that are translated as equivalents, and (ii) that Japanese speakers within Japanese society definitely do not feel 'shame' or 'embarrassment' as these terms are used in typical English speaking contexts, as neither the sociocultural context nor the value systems from which the words derive are the same.

\section{QUESTIONING THE IDEA OF UNIVERSAL EMOTION CONCEPTIONS}

The semantic differences between 'haji' and 'shame' and between 'hazukashii' and 'embarrassing' undermine the assumption that these terms can be directly and exactly translated into English and Japanese. Considering the meanings of both 'shame' and 'haji', how could one ever determine which term denotes the universal emotion, and why would one try? The point is that neither can be universal because they are both semantically different from their closest correlate, as this paper tries to show. Currently, there is no evidence of a worldwide conception of a feeling called 'shame' on which people from all cultures agree exactly.

In a paper by Kimball Romney et al. (1997), the authors tried to prove the existence of universal emotions comparing precisely English and Japanese. They tried to measure the semantic structure of various emotion terms in English and Japanese through a mathematical model, asking native speakers of both languages to locate various emotion terms on a Euclidean graph. According to their analysis, the same emotion located in the same place both by an English and a Japanese speaker would reflect shared cognitive representations of the semantic structure of a given term, which would prove the universality of that concept. By contrast, an emotion term located in completely different places by English and Japanese speakers would reflect a conceptual difference in these two languages. One emotion term which turned out to be conceived quite differently according to this study is 'shame'.

The authors observe that, in comparison with the Japanese word 'hazukashii', the location of the English term 'shame' tends more towards the "unpleasant" side in the graph where other "negative" emotions are located $(1997,5490)$. However, they do not clarify what they mean by "unpleasant" or "negative", and in what ways 'shame' is "more unpleasant" than 'hazukashii. They do recognise that the different locations of this feeling reflect a difference in the meaning of the words. At the same time, they suggest that, although their Japanese 
participants translated 'hazukashii' both as 'shameful' and 'embarrassing', the Japanese concept is closer to 'embarrassing' than 'shameful' (1997, 5490), which is the hypothesis put forward in the present study, too.

The position taken in this paper endorses the NSM researchers' opinion that a comparison between different, culture-specific concepts cannot be based merely on native speakers' intuitions (as in the study conducted by Kimball Romney et al.), both because native speakers are not fully representative of their culture and because they can be influenced by how they would express a concept in another language (e.g., English or Japanese). More importantly, the approach to the present study is that a semantic analysis of a cultural concept, including emotion terms, cannot be made using the technical jargon of one particular language (English, and by inference Japanese), but only using a methodology based on universal concepts like THINK, FEEL, KNOW and DON'T WANT which allows the capturing of an indigenous perspective and makes it accessible to linguacultural outsiders.

\section{CONCLUSION}

The present analysis pinpoints how the terms haji and hazukashii are conceived by Japanese speakers and identifies the cultural salience of these two emotion terms in Japanese society. An element which has emerged as both semantically and culturally central to the meaning of both terms is the apparent pressure of society on an individual's behaviour. In both cases, the bad feeling seems to derive from the fear that one's actions may be in contrast with social norms which are context-specific. If this is the case, this will attract people's criticism, and produce consequent effects that might include damage to the actor's reputation. This element appears to be consistent with what scholars have identified as a key cultural value in Japan-essentially, the importance of group consciousness-and its inherent implications, which include a greater emphasis on shared responsibility.

Another key point made in the discussion is that a clear understanding of how an emotion is conceived in a linguistic and cultural environment can lead to an awareness of the specificity of the context and how it influences that conception, and consequently, to a less homogeneous idea of emotions themselves. Once again, the semantic differences between emotion terms of different languages make conceptual differences more evident.

Once semantic differences are identified, I have argued that these must be explicated using simple and cross-translatable words so that the resulting explications are recognisable to both speakers of thelanguage being investigated as well as speakers of the language of investigation. The explications presented in this paper are directly translatable into Japanese, and therefore can be both tested against the intuitions of Japanese native speakers and be successfully used for cross-cultural training.

To conclude, the present study is certainly limited in scope and confirms the need for further research on such a long-debated topic. What the paper 
has hopefully demonstrated is that the methodology of NSM can serve as an optimal tool in translation and in cross-cultural training, and can contribute

to the study of the relationship between language and culture.

\section{ACKNOWLEDGEMENTS}

I am deeply grateful to Anna Wierzbicka, Cliff Goddard, Adam Broinowski, Elicia O'Reilly and all my Japanese friends for the comments and suggestions received.

\section{APPENDIX}

Japanese NSM Primes with English Equivalents, grouped into semantic categories (Asano-Cavanagh and Farese 2015)

\begin{tabular}{|c|c|}
\hline $\begin{array}{l}\text { 私 WATASHI, あなた ANATA, 誰か DAREKA, 何か〜もの〜こと } \\
\text { NANIKA MONO KOTO, 人々HTO-BITO, 体 KARADA }\end{array}$ & \multirow[t]{2}{*}{ substantives } \\
\hline I, YOU, SOMEONE, SOMETHING THING, PEOPLE, BODY & \\
\hline 種類 SHURUI, 部分 BUBUN & \multirow[t]{2}{*}{ relational substantives } \\
\hline KINDS, PARTS & \\
\hline これ〜これら KORE KORERA，同じ ONAJ,他 HOKA & \multirow[t]{2}{*}{ determiners } \\
\hline THIS, THE SAME, OTHER $\sim$ ELSE & \\
\hline $\begin{array}{l}\text { 一 HITO ICHI, 二 FUTA NI, いくつか〜何人か IKUTSUKA NANNINKA, } \\
\text { すべて SUBETE, たくさん TAKUSAN, 少し SUKOSHI }\end{array}$ & \multirow[t]{2}{*}{ quantifiers } \\
\hline ONE, TWO, SOME, ALL, MUCH MANY, LITTLE FEW & \\
\hline 良い YOI, 悪い WARUI & \multirow[t]{2}{*}{ evaluators } \\
\hline GOOD, BAD & \\
\hline 大きい OOKII, 小さい CHIISAI & \multirow[t]{2}{*}{ descriptors } \\
\hline BIG, SMALL & \\
\hline $\begin{array}{l}\text { 知る SHIRU, 思う〜考える OMOU KANGAERU,たい〜欲しい〜望む } \\
\text {-TAI HOSHII-NOZOMU, たくない〜欲しくない〜望まない } \\
\text {-TAKUNAI HOSHIKUNAI NOZOMANAI, 感じる KANJIRU, 見る MIRU, 聞 } \\
\text { く KIKU }\end{array}$ & \multirow[t]{2}{*}{ mental predicates } \\
\hline KNOW, THINK, WANT, DON'T WANT, FEEL, SEE, HEAR & \\
\hline 言う IU, 言葉 KOTOBA, 本当 HONTŌ & \multirow[t]{2}{*}{ speech } \\
\hline SAY, WORDS, TRUE & \\
\hline する SURU, 起こる〜起きる OKORU OKIRU, 動く UGOKU & \multirow{2}{*}{$\begin{array}{r}\text { actions, events, } \\
\text { movement }\end{array}$} \\
\hline DO, HAPPEN, MOVE & \\
\hline $\begin{array}{l}\text { （どこかに）いるーある(DOKOKANI) IRU-ARU, ある〜いる } \\
\text { ARU IRU,（誰かー何か) である (DAREKA-NANIKA) DEARU, }\end{array}$ & \multirow[t]{2}{*}{$\begin{array}{r}\text { location, existence } \\
\text { specification }\end{array}$} \\
\hline BE (SOMEWHERE), THERE IS, BE (SOMEONE/SOMETHING) & \\
\hline 私のである (WATASHINO) DEARU & \multirow[t]{2}{*}{ possession } \\
\hline (IS) MINE & \\
\hline 生きる IKIRU, 死ぬ SHINU & \multirow[t]{2}{*}{ life and death } \\
\hline LIVE, DIE & \\
\hline $\begin{array}{l}\text { いつ〜時〜回 ITSU TOKI KAI, 今 IMA, 前 MAE, 後 ATO, 長い間 } \\
\text { NAGAI AIDA, 短い間 MIJIKAI AIDA, しばらくの間 SHIBARAKU NO AIDA, } \\
\text { すぐに〜一瞬 SUGUNI ISSHUN }\end{array}$ & \multirow[t]{2}{*}{ time } \\
\hline $\begin{array}{l}\text { WHEN TIME, NOW, BEFORE, AFTER, A LONG TIME, A SHORT TIME, FOR SOME } \\
\text { TIME, MOMENT }\end{array}$ & \\
\hline $\begin{array}{l}\text { どこ〜所〜どこか DOKO TOKORO DOKOKA, ここ KOKO, 上 UE, 下 } \\
\text { SHITA, 遠い TOOI, 近い CHIKAI, 面 MEN, 中 NAKA, 触る SAWARU }\end{array}$ & \multirow[t]{2}{*}{ place } \\
\hline WHERE PLACE, HERE, ABOVE, BELOW, FAR, NEAR, SIDE, INSIDE, TOUCH & \\
\hline $\begin{array}{l}\text { ない NAI, 多分 TABUN, できる〜得る DEKIRU ERU/URU,から KARA, } \\
\text { (もし) - ゙ (MOSHI) -BA }\end{array}$ & \multirow[t]{2}{*}{ logical concepts } \\
\hline NOT, MAYBE, CAN, BECAUSE, IF & \\
\hline すごく SUGOKU,もっと〜もう MOTTO Mō & \multirow[t]{2}{*}{ intensifier, augmentor } \\
\hline VERY, MORE & \\
\hline よう〜ように Yō〜YōNI & \multirow[t]{2}{*}{ similarity } \\
\hline LIKE AS & \\
\hline
\end{tabular}




\section{REFERENCES}

Asano-Cavanagh, Y. 2002. "How to Be Indirect in Japanese: A Cultural Script Approach.” RASK Internationalt tidsskrift for sprog og kommunikation [RASK International Journal of Language and Communication] 17: 23-51.

. 2014. "Japanese Interpretations of 'Pain' and the Use of Psychomimes." International Journal of Language and Culture 1 (2): 216-38.

Asano-Cavanagh, Y. and G. M. Farese. 2015. “NSMセマンチクプライムのチャート”. Accessed 14 July, 2015. http://www.griffith.edu.au/humanities-languages/ school-languages-linguistics/research/natural-semantic-metalanguage homepage.

Benedict, R. 1946. The Chrysanthemum and the Sword. Cambridge (USA): Houghton Mifflin.

De Mente, B. L. 2004. Japan's Cultural Code Words. North Clarendon: Tuttle Publishing.

Doi, T. 1974. The Anatomy of Dependence. New York: Kodansha International.

Gluck, C. 2009. "Sekinin/Responsibility." In Words in Motion: Toward a Global Lexicon, edited by C. Gluck and A. Lowenhaupt Tsing, pp 83-108. Durham and London: Duke University Press.

Goddard, C., ed. 2008. Cross-Linguistic Semantics. Amsterdam: John Benjamins.

2011. Semantic Analysis: A Practical Introduction. 2nd edition. Oxford: Oxford University Press.

Goddard, C. and A. Wierzbicka. 1994. Semantic and Lexical Universals: Theory and Empirical Findings. Amsterdam: John Benjamins.

2002. Meaning and Universal Grammar: Theory and Empirical Findings. Amsterdam: John Benjamins.

2014. Words and Meanings. Lexical Semantics Across Domains, Languages and Cultures. Oxford: Oxford University Press.

Goddard, C. and Z. Ye, eds. 2014. “'Happiness' and 'Pain' Across Languages and Cultures." The International Journal of Language and Culture 1 (2). http://dx.doi.org/10.1075/ijolc.1.2

Goo Jisho [Goo 辞書]. n.d. [a]. 'Haji' [恥]. Accessed 10 July, 2015. http://dictionary.goo.ne.jp/thsrs/4108/meaning/m0u/恥/。

Goo Jisho [Goo 辞書]. n.d. [b]. 'Hazukashii' [恥ずかしい]. Accessed 10 July, 2015. http://dictionary.goo.ne.jp/jn/176287/meaning/m0u/恥ずかしい/

Hasada, R. 2003. "Cultural Scripts on Japanese Attitude Towards Emotion.” Tokyo University of Foreign Studies Bulletin of Japanese Language Center for International Students 29: 27-67. 
2006. "Cultural Scripts: Glimpses Into the Japanese Emotion World". In Ethnopragmatics: Understanding Discourse in Cultural Context, edited by C. Goddard, 171-98. Berlin: Mouton de Gruyter.

Ikeno, O. and R. Davies. 2002. The Japanese Mind. Boston, MA: Tuttle Publishing.

Kachru, B. 1985. "Standards, Codification and Sociolinguistic Realism: The English Language in the Outer Circle". In English in the World: Teaching and LearningtheLanguageandLiteratures, editedbyR.QuirkandH.G.Widdowson, 11-30. Cambridge: Cambridge University Press.

Kawabata Y. [川端 康成]. 1957. Yama no oto [山の音]. Tokyo: Shinchōsha [新潮社].

1970 [1954]. The Sound of the Mountain. Translated by E. G. Seidensticker. London: Secker and Warburg.

Kimball Romney, A., C. Moore and C. Rusch. 1997. "Culture Universals: Measuring the Semantic Structure of Emotion Terms in English and Japanese." The National Academy of Sciences of the USA 94: 5489-94.

Kotonoha Corpus of Japanese. 2009. Accessed 14 July, 2015. http://www.kotonoha. gr.jp/shonagon/.

Lebra, T. S. 2007. Identity, Gender and Status in Japan. Folkestone: Global Oriental.

Lutz, C. 1985. "Depression and the Translation of Emotional Worlds." In Culture and Depression: Studies in the Anthropology and Cross-Cultural Psychiatry of Affect and Disorder, edited by A. Kleinman and B. Good, 63-100. Berkeley: University of California Press.

Mishima, Y. [三島 由紀夫]. 1979. Kinkakuji [金閣寺]. Tokyo: Shinchōsha [新潮社]. 1990 [1971]. Haru no yuki [春の雪]. Tokyo: Shinchōsha [新潮社]. 2000. Spring Snow. Translated by M. Gallagher. London: Vintage.

2001 [1959]. The Temple of the Golden Pavilion. Translated by I. Morris. London: Vintage.

Murakami, H. 2014. Colorless Tsukuru Tazaki and His Years of Pilgrimage. Translated by P. Gabriel. London: Harvill Secker.

Sakuta, K. [作田 啓一]. 1967. Haji no bunka saikō [恥の文化再考]. Tokyo: Chikuma Shobō [筑摩書房].

Wierzbicka, A. 1996. Semantics: Primes and Universals. Oxford: Oxford University Press.

1999. Emotions Across Languages and Cultures. Cambridge: Cambridge University Press.

2006. English: Meaning and Culture. Oxford: Oxford University Press.

2014. Imprisoned in English. Oxford: Oxford University Press. 
Ye, Z. 2006. "Why Are There Two 'Joy-like', 'Basic' Emotions in Chinese?: Semantic Theory and Empirical Findings". In Love, Hatred, and Other Passions: Questions and Themes on Emotions in Chinese Civilization, edited by P. Santangelo, 59-77. Netherlands: Koninklijke Brill.

. 2014. “The Meaning of 'Happiness' (xingfu) and 'Emotional Pain' (tongku) in Chinese”. In International Journal of Language and Culture 1 (2): 194-215.

Yoshimoto, B. [吉本 ばなな]. 1988. Kitchin [キッチン]. Tokyo: Fukutake Shoten [福武 書店].

1993 [1988]. Kitchen. Translated by M. Backus. New York: Washington Square Press.

2006. Jinsei no tabi wo yuku [人生の旅をゆく]. Tokyo: Nippon Hōsō Shuppan Kyōkai [日本放送出版協会]. 


\section{A Centaur in Salaryman's Clothing: Parody and Play in est em's Centaur Manga}

\section{ANNE LEE}

The University of Queensland
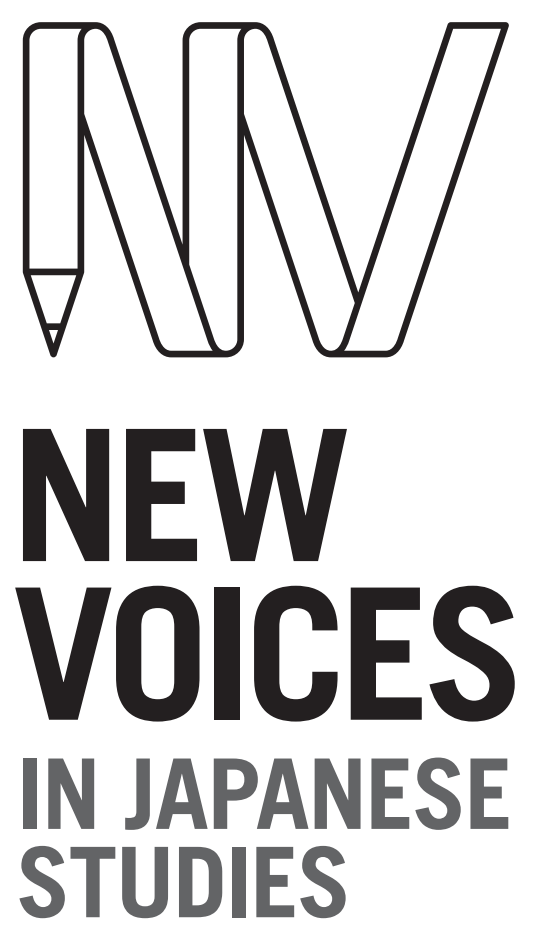

\section{ABSTRACT}

Japanese manga artist est em (esu to emu) is notable for blurring genre boundaries and subverting established conventions in various publications since her debut in 2006. Two of her works, Hatarake, kentaurosu! ('Work, Centaur!') and equus, focus exclusively on male centaurs in homosocial settings. Classified as shōjo (girls') manga and BL ('boys' love') manga respectively, these two works allow female readers to enjoy the pleasures of homoerotic subtexts and intertextual parody. This paper examines how conventions of sexuality and gender, particularly hegemonic masculinity and heterosexuality, are constructed/deconstructed in est em's centaur manga using the framework of intertextuality, with particular emphasis on parody, pleasure and play. By placing centaurs in realistic, everyday settings, these works present a critique of Japan's contemporary salaryman culture, while also highlighting issues of alienation and otherness that both female readers and gay men face in their daily lives.

\section{KEYWORDS}

boys' love (BL); centaurs; gender; comedy/humour; intertextuality; manga; sexuality; parody; popular culture; representation; salaryman; shōjo

\section{JAPANFOUNDATION \& BRINGING JAPAN TO YOU \\ To link to this article: http://dx.doi.org/10.21159/nvjs.08.03 \\ ISSN 2205-3166}

New Voices in Japanese Studies is an interdisciplinary, peer-reviewed journal showcasing the work of emerging scholars from Australia and New Zealand with research interests in Japan.

All articles can be downloaded free at newvoices.org.au

(c) The Japan Foundation, Sydney and Anne Lee, 2016

\section{(c) (i) $(9)$}

This work is licensed under a Creative Commons Attribution-NonCommercialNoDerivatives 4.0 International License. 


\section{INTRODUCTION}

In the vast world of manga there is a genre for every interest, no matter how obscure. From realistic sports dramas to tales of princesses from other worlds, manga span a wide range of genres and themes (see Ito 2005; Schodt 1983). Greek mythology, for example, influenced many manga series, including smash hits such as Seinto seiya [Saint Seiya: Knights of the Zodiac; 1986] and Bishōjo senshi sērā mūn [Pretty Guardian Sailor Moon; 1991]. ${ }^{1}$

Centaurs, in particular, are prominently featured in a number of manga published in 2011: Sentōru no nayami [A Centaur's Life] by Kei Murayama, Zeusu no tane ['Zeus' Seed'] by Kōsuke Iijima, Ryū no gakkō wa yama no ue ['The Dragon's School is on the Mountain Top'] by Ryōko Kui, and equus and Hatarake, kentaurosu! ['Work, Centaur!'] by est em (えすとえむ; esu to emu). ${ }^{2}$ However, instead of focusing on centaurs in exotic, mythological settings, each of these narratives insert centaur characters into normal, everyday settings. ${ }^{3}$ Sentōru no nayami focuses on the mundane aspects of living as a centaur in a world closely resembling modern Japan but inhabited exclusively by fantastical creatures. Meanwhile, Zeusu no tane and Ryū no gakkō wa yama no ue both present centaurs coexisting with humans. est em's two centaur works, equus and Hatarake, kentaurosu!, follow this same trend of placing centaurs in a variety of real-world situations, centering particularly around male centaurs in homosocial settings. The juxtaposition of these half-human, half-horse creatures with familiar, real-world environments highlights the centaurs' otherness: although their upper bodies are identical to those of humans, their bottom horse-halves pose numerous obstacles to inhabiting a world built primarily for bipedal humans. By inserting male centaurs in relatable situations for readers, est em's works offer opportunities to explore culturally established gender and social structures through the use of intertextual parody and play.

This article examines how social and gender conventions, particularly hegemonic masculinity and heterosexuality, are constructed/deconstructed in est em's centaur manga using the framework of intertextuality, with particular emphasis on parody, pleasure and humour/laughter. It analyses how parody is utilised in Hatarake, kentaurosu! and equus in both social and literary contexts, exploring how manga aimed at a female audience incorporates criticism of gender and issues of inequality while simultaneously transforming such issues into sources of pleasure. Linda Hutcheon (1985) defines parody as "ironic playing with multiple conventions, [and] extended repetition with critical difference" (7). The pleasure of decoding a parodic text and the playful way in which gender restrictions are subverted within this type of manga can also be linked back to discourse on the subversive power of women's laughter to disrupt patriarchal authority and social systems (Cixous 1975). While it

1 A bibliography of titles mentioned in this paper is provided as an Appendix. The bibliography includes titles and author names in Japanese script. English titles in italics are official translations, while those in single quotes are the author's translations.

2 est em, a pen name, is a play on the Japanese pronunciation of S\&M (エスとエム; esu to emu). She intentionally keeps her name uncapitalised in official publications.

3 Sentōru no nayami, Zeusu no tane, Ryū no gakkō wa yama no ue and Hatarake, kentaurosu! all take place in modern-day Japan or fantastical settings with cultural similarities to Japan. equus is comprised of numerous 
may seem obvious to mention that girls and women read because it brings pleasure, literary criticism tends to neglect the role of pleasure in the act of reading (Barthes 1973). Even so, the subversion of established hierarchies such as gender norms in women's literature is often linked to pleasure and humour (Aoyama 1994), making it necessary to explore how themes of textual pleasure such as laughter and play aid in an analysis of parody in these manga. Rather than demanding immediate, radical change to the gender and social status quo, these texts engage with restrictive social and gender structures through playful subversion (Aoyama and Hartley 2010, 7).

As Tomoko Aoyama (2012) notes, instead of "directly protesting patriarchal and heterosexist oppression," intertextual parody can "transform existing inequalities and potential threats into pleasure and gratification" (66). Parody may not always be humorous in nature, but the "intertextual pleasure" experienced by "knowing readers" who move between multiple texts offers numerous levels through which readers can enjoy a particular work (Hutcheon 2006, 117). Through playful transformation and allusion, equus and Hatarake, kentaurosu! present an alternative to a repressive patriarchal society, despite the almost complete absence of female characters. These narratives are greatly enhanced by what Aoyama describes as "BL literacy," or "the ability to read and write/draw male homoerotic narratives according to, while often at the same time subverting, the specific conventions of this genre" $(2012,66) . \mathrm{BL}$, an acronym for boizu rabu (ボイズラブ; 'boys' love'), ${ }^{4}$ denotes male-male romance manga aimed at a female audience, often containing explicit sexual material. BL literacy not only informs the way readers engage with est em's BL narratives, but also her other works that do not fall within the genre.

Since making her professional debut in 2006 with the BL manga Sho ga hanetara aimashō [Seduce Me After the Show], est em has repeatedly blurred the distinction between heternormative shōjo (少女; girls') manga and homoerotic BL. While other centaur manga published in 2011 are marketed towards shōnen (少年; boy) and seinen (青年; young adult male) readers, est em's equus and Hatarake, kentaurosu! are sold as BL and shōjo manga respectively. Shōjo manga initially emerged in the mid-1950s as a distinct marketing genre separate from shōnen, with roots in the shōjo culture established by shōjo shōsetsu (少女小説; girls' novels) and sashie (挿絵; illustrations) popular among schoolgirls in the 1920s and 30s (Honda 2010, 13). Although Osamu Tezuka's Ribon no kishi [Princess Knight; 1953] is often cited as the first shōjo manga, Yukari Fujimoto argues that many of the distinctive shōjo manga features such as large, star-filled eyes, unconventional panel layouts and expository narration were pioneered by Macoto Takahashi's Arashi o koete ['Beyond the Storm'], which began serialisation in 1958 (Fujimoto 2012, 24).

Shōjo manga became increasingly defined in the 1960s and 70s, and shōnen ai (少年愛; lit., 'boys' love') narratives featuring romantic relationships between beautiful young boys grew exponentially in popularity within the genre (McLelland 2000). These stories about love between boys were an outlet for readers, from adolescent girls to young adult women, to explore their sexuality without the risk of alienation, depicting love between equals and 
more graphic depictions of sex than was acceptable in heterosexual romances of the time (Ishida 2008). Now known as BL, this subgenre of shōjo manga remains a significant imaginary domain where readers are not restricted to mainstream culture's rigid definition of heteronormative desire, thereby providing an escape from the negative elements of socially constructed female identity (Kan 2010, 55).

It is worthwhile to consider how the escape presented by BL and BL-informed narratives has the potential to inspire change. As Terry Eagleton (1983) asserts, "rather than merely reinforce our given perceptions, the valuable work of literature violates or transgresses these normative ways of seeing, and so teaches us new codes for understanding" (68). Just as centaurs embody the best attributes of horse and man, est em's equus and Hatarake, kentaurosu! do not neatly adhere to genre or social conventions, but instead combine and reconsider aspects of both. Blurring the lines between man and horse as well as shojo and BL manga, these texts offer a complex look at the world of human and centaur interactions from the perspective of the female outsider. BL literacy enables readers to enjoy the pleasures of subverting traditionally homosocial situations through parody and play, while encouraging contemplation of alternatives to patriarchal norms.

\section{HOMOEROTICISM AND HALF-BEASTS IN JAPANESE LITERATURE}

Outside of traditional Greek mythology, human-animal hybrid creatures have long resonated with Japanese writers and artists. Named after the halfman, half-goat god Pan, the Pan Society (パンの会) was “an organisation that sought to promote interaction between visual artists and poets and to imitate the café discussions of art and literature common to France in the late nineteenth century" (Angles 2011, 6). Some of Japan's most important authors and artists of the early twentieth century attended the Pan Society, such as Jun'ichirō Tanizaki [1886-1965] and Kafū Nagai [1879-1959]. God of nature and shepherds, Pan was often associated with sexuality. According to Pan Society scholar Utarō Noda, author Mokutarō Kinoshita [1885-1945] selected a restaurant located by the Sumida River in Ryōgoku, Tokyo, for the society's first meeting in December 1908 due to its association with old Edo culture and the Seine, the symbol of French art and literature (Aoyama 1992, 281). As noted by Aoyama, the society was heavily characterised by occidentalism and exoticism, valuing various aspects of Edo culture not due to nostalgia but for "the same kind of exoticism as displayed by European artists, especially impressionists, in welcoming the ukiyoe prints" (Aoyama 1992, 282).

Similar to Pan, Greek centaurs were neither mortal nor immortal; they lived in forests, and were depicted as uncultured, impulse-driven creatures that amplify the complex dual natures of humans. Originating from the Greek 'Centaurus', or 'Kentaurus', centaurs were often associated with their love for "sex, food, and alcohol" (Padgett 2003, 3). The 'kentaurosu' in est em's Hatarake, kentaurosu! derives from the Greek 'Kentaurus', while also humorously referencing Osamu Dazai's mock-heroic tale Hashire Merosu 
[Run, Melos!]. One of the most prominent centaurs in Greek mythology is Chiron, a teacher, oracle, and healer who mentored numerous great heroes such as Achilles. Unlike Greek satyrs, which were a mixture of horse or mule and human characteristics, centaurs were not an amalgamation, but rather featured a divide at the waist between man and equine. Neither fully man nor fully horse, centaurs complicate classic divisions between animal/human and nature/civilisation. By occupying spaces also inhabited by humans, est em's centaurs further problematise these distinctions. Although the concept of "centaur" is never treated as fantastical within her narratives, the difficulties associated with inhabiting a world where centaurs are treated as a minority are present in all of her stories.

Before turning to est em's manga, however, it is necessary to consider the long history that homosocial literature with homoerotic undertones (or, not infrequently, overtones) has in Japanese culture. Shōjo manga are often praised for widespread depictions of male-male romance (see Fujimoto 1998), but the roots of women writing male-male romance can be traced back as far as The Tale of Genji (源氏物語) in the early eleventh century. Historically, homoerotic literature in Japan was not an abnormality, but rather an "elaborate cultural tradition" that, until the late nineteenth century, "figured in the cultural imagination as a familiar literary trope, as a legitimate and widely accepted practice, and as a nexus of cultural value" (Vincent 2012, 3). During the Edo period [1603-1868], the terms nanshoku (男色; also read danshoku, meaning 'male eros') and shudō or wakashudo (衆道・若衆道; the way of the youth) were used to describe male-male desire, referring specifically to the relations between adult men and young boys who had not yet completed the genpuku (元服) ${ }^{6}$ coming-of-age ceremony (Angles 2011, 5-6). When the publishing industry expanded in the Edo period, an increasing number of texts emerged extolling the virtues of cultivating the pleasures of men, indicating a growing interest in male-male eroticism among the cosmopolitan public (Angles 2011, 6).

In the early twentieth century, however, Japan moved increasingly toward a compulsorily heterosexual patriarchal society in an attempt to be seen by Western nations as more modern and enlightened. Cultural historian Gregory Pflugfelder (1999) notes that during the Meiji period [1868-1912], homoeroticism came to be "routinely represented as 'barbarous,' 'immoral,' or simply 'unspeakable"' in popular discourse as Japan adopted Western rhetoric on sexuality (193). Increasingly viewed as uncivilised and immature, nanshoku was replaced with doseiai (同性愛; lit., “same-sex love”), a term informed by European notions of homosexuality that could be used to refer to both male-male and female-female desire. The shift toward compulsory heterosexuality seen in early twentieth-century Japan saw a rupture of what Eve Kosofsky Sedgwick (1992) theorises as the "male homosocial continuum," which connects "men-loving-men" and "men-promoting-the-interests-ofmen" (3). Although dealing with British literature, Sedgwick notably drew the "'homosocial' back into the orbit of 'desire,' of the potentially erotic" in modern Western culture $(1992,1)$. Regarding Japanese literature in the early twentieth century, Keith Vincent (2012) notes that "[Japan's] newly heteronormative

5 Such relationships share similarities with those between an adult man (erastes) and younger male (eromenos) prevalent in Ancient Greece (Reeve 2006, xxi).

6 Also read as 'genbuku'. 
culture was unable and perhaps unwilling to expunge completely the recent memory of a male homosocial past now read as perverse" (3). Thus, while male-male eroticism is no longer privileged in Japan as it was in the Edo period and earlier, its long history in Japanese literary culture has been influential in the realm of manga.

\section{NIOI-KEI AND BL LITERACY}

To date, extensive research has been conducted in both English and Japanese in the areas of shojo and BL manga. While there is still some inconsistency in the use of the term BL within scholarship (McLelland and Welker 2015, 5), this article uses Kayo Takeuchi's (2010) definition of BL as "a term that came into usage during the latter half of the 1990s, indicating, for the most part, original stories written/drawn by professional writers in both shöjo manga and shōjo shōsetsu issued by established publishing houses" (91) that focus on male-male romance. As McLelland and Welker note, while shōjo manga target female readers from pre-adolescence to young adulthood, many shōjo works have an actual readership that includes older women and male readers (4).

According to Junko Kaneda (2007), BL research generally takes two forms: a psychological approach exploring the appeal of homoerotic narratives to a predominantly female readership, or a gender studies approach that considers the subversive potential of the genre. Indeed, the majority of BL scholarship has largely focused on why girls and women read BL manga and what BL means for its readers and society (e.g., McLelland 2000; Ueno 1989; Wood 2006). Fewer scholars have looked at how the constantly evolving BL genre does not neatly adhere to any one definition, nor remain an untouched entity separate from shōjo manga, and what this blurring of genres means for manga written by and for women. Indeed, Akiko Mizoguchi (2010) suggests that certain non-BL works would not exist without BL as a platform for "examining the fundamental questions of sexuality, reproduction, and gender ... within the framework of entertaining fiction with sexual depictions" (163). Kumiko Saito (2011) expands on this further, noting that the heterosexual romances in a number of successful manga for women such as Tomoko Ninomiya's Nodame Kantābire [Nodame Cantabile; 2001] and Chika Umino's Hachimitsu to kurōbā [Honey and Clover; 2000] are informed by the common BL trope of romances forming out of friendship based on "matching abilities and competition" (188).

est em's first centaur manga, Hatarake, kentaurosu!, notably falls within this spectrum of non-BL works informed by BL. Its varied publication history gives insight to the intended audience and potential readings of the text. The short stories that are compiled in Hatarake, kentaurosu! originally appeared in girls' and young women's manga magazines Kurofune ZERO ['Black Ship ZERO'] and BE·BOY GOLD.7 Though BE.BOY GOLD targets a $\mathrm{BL}$ readership, none of the stories published in neither it nor Kurofune ZERO 
contain explicitly romantic relationships between men. Instead, these stories focus on centaurs living and working in modern Japan in predominantly homosocial settings. Unlike BE.BOY GOLD, Kurofune ZERO does not serialise BL manga. However, it has featured a slice-of-life series titled Fujoshi no hinkaku ['Fujoshi's Dignity'; 2008] that focused on the lives of two fujoshi ( 腐女子), or female BL fans. This suggests that Kurofune ZERO readers identify as, or relate to, fujoshi, despite the fact that the magazine does not target a specifically BL readership. Furthermore, est em's large body of BL publications may lead readers of Hatarake, kentaurosu! to imagine the male protagonists in a romantic relationship, even though it is never depicted in the manga.

Four of the eight chapters in Hatarake, kentaurosu! prominently feature Kentarō (see Figure 1), a centaur who works as a salaryman at a horse tack manufacturer. From this premise alone, there are already multiple layers of parody. First, the irony and hint of masochism in a centaur working for a saddlery manufacturer is surely not lost on est em's readers. In addition, Kentarō, a common male Japanese first name, also evokes the Greek word for centaur, from which the loanword 'kentaurosu' derives. To the Japanese reader, Kentarō can also be read as a parody of Kintarō, a hero in vernacular narrative. Perhaps most famously, the Kintarō of traditional Japanese folklore is a sturdy young mountain boy who befriends animals, suggesting the blurring of the human/animal divide mirrored in the centaurs themselves.

Additionally, Kintarō may also evoke the titular Kintarō Yajima, protagonist of the massively popular seinen manga series Sarariiman Kintarō ['Salaryman Kintarō']. ${ }^{8}$ The manga, which has been serialised on and off in Shükan yangu janpu ['Weekly Young Jump'] since 1994, follows former bōsōzoku (暴走 族; motorcycle gang) leader Kintarō, who becomes a salaryman to raise his son after his wife passes away in childbirth. With only a junior high school education, Kintarō is hired by a construction company after saving the life of its CEO, and almost accidently goes on to become a successful businessman. Unlike Kentarō, who is a model for the traditional salaryman archetype aside from the fact that his lower body is a horse, Kintaro is in many ways its antithesis, embodying a hyper-masculine bravado and defiance that Ikuya Sato (1991) observes in bōsōzoku masculinity (69). However, by eventually conforming to the image of a respectable, urban salaryman by putting his company's needs before his own, Kintarō comes to represent the synthesis of both the salaryman and the warrior, although Romit Dasgupta (2003) argues that "this aggressively idealised figure ... ends up as little more than a caricature" (128).

Both Kintarō and Kentarō's work environments are nearly entirely comprised of men, harking back to Sedgwick's continuum of homosocial desire. Kentarō's friendship and interactions with his unnamed human co-worker, which is a focal point of many of the chapters, can easily be read as homoerotic by readers literate in BL manga. The emphasis on friendship between men is also a central theme of Osamu Dazai's famous 1940 short story Hashire Merosu, which the title Hatarake, kentaurosu! likely evokes for Japanese readers. Based 
on the retelling of the Greek legend of Damon and Phintias in "The Hostage" [1799] by German poet Friedrich Schiller, Hashire Merosu is included in many Japanese school curricula and popular collections of Dazai's work. In the story, the shepherd Melos is enraged when he learns that the king Dionysus is killing citizens and even his own family members due to his distrust of others. Determined to put an end to his tyranny, Melos attempts to assassinate the king with a knife, but is quickly apprehended and sentenced to death. After pleading with the king to allow him to attend his younger sister's wedding, Melos is released on the condition that he return within three days. In exchange for Melos' release, the king takes his best friend Selinuntius hostage, and vows to execute him instead if Melos does not return before the deadline.

After attending his sister's wedding, Melos journeys back to the king to fulfil his promise. Along the way, he is repeatedly thwarted by various obstacles, but hurries on in the hope of reaching Selinuntius before the execution. The story ends with Melos returning in the nick of time to embrace Selinuntius, an act of loyalty and friendship that moves the king so much that he revokes Melos' sentence and asks to become friends with the two men. Translator James O'Brien (1989) notes in the English Dazai collection Crackling Mountain and Other Stories that many critics see the hero Melos as "embodying ideas of trust, fidelity, and friendship" (111). However, O'Brien suggests that the story reads more as a "mock-heroic" tale, with Melos depicted as a "proud simpleton" rather than a hero. This is most evident in a scene at the end of the narrative where Melos is "foolishly aware of his own nakedness" $(1989,111)$ for the first time, after running all the way back to the castle. Notably, this scene was absent from Schiller's original poem and is removed from versions of Hashire Merosu distributed in schools, diminishing the comical element within Japan's cultural narrative $(1989,111)$.

The deep friendship depicted between Melos and Selinuntius can also be identified as an example of nioi-kei (臭い系), a term used to identify texts that demonstrate a hint or 'whiff' of BL to BL-literate readers (Aoyama 2012, 66). By combining nioi (臭い; scent) with kei (系), which is frequently used to designate subcategories in $\mathrm{BL}$, fashion and other forms of contemporary popular culture, the term indicates to readers within the "imagined BL community" (Aoyama 2012, 73) the potential for BL within the text, no matter how faint it may be. While Natsume Sōseki's Kokoro [1914] was ranked the number one "nioi-kei literary masterpiece" in the February 2009 issue of book/manga review magazine Da Vinchi ['Da Vinci'], Hashire Merosu was also selected for its nioi-kei properties by readers. Comments from two of the women polled were as follows:

Reading this as an elementary school student who didn't know BL, I thought, “These aren't normal friends, are they?"9 (female, office worker, 40)

They trust each other enough to risk their lives for one another, so it's obvious [that it's BL]..$^{10}$ (female, office worker, 40 ) 
The first comment suggests that even at a young age, the reader sensed a 'more than friends' connection between Melos and Selinuntius. As previously indicated, the text is included in many school curricula, which extol the deep friendship between the two men. However, in a dialogue in the same issue of Da Vinchi, BL novelist Natsuki Matsuoka and writer and BL enthusiast Shion Miura joke that the reasoning behind Melos attacking the king, or for Selinuntius to wait so diligently for his return, is “full of [plot] holes” (すべて に穴がある) (Matsuoka and Miura 2009, 30). Rather than considering this a detriment to the narrative, they assert that it is the holes themselves that enable the BL nioi to seep through $(2009,30)$. Echoing the second reader comment, the two read the pair risking their lives for one another as love, rather than friendship. In the same way, BL-literate readers of Hatarake, kentaurosu! may also smell the nioi in the homosocial narrative, allowing the possibility for the relationship between Kentarō and his human colleague to be interpreted as implied BL.

\section{THE EVOLUTION OF THE SALARYMAN}

Through a nioi-kei reading, Hatarake, kentaurosu! invites female readers to imagine the possibility of male-male desire in the historically exclusive realm of salarymen. For many years, the salaryman, a model male employee and member of a heteronormative family unit, exemplified the hegemonic masculine ideal in Japan. According to Dasgupta (2013), "typically the salaryman would be a middle-class, university-educated middle-aged man, with a dependent wife and children to support, working for an organisation offering such benefits as secure lifetime employment ... and a promotions and salary scale linked to seniority" (1). Sociologist Raewyn Connell (1987) describes societal hegemony as "a social ascendancy achieved in a play of social forces that extends beyond contests of brute force into the organisation of private life and cultural processes" (184). This ascendancy is "achieved not so much through blatant domination and force, but rather in more subtle ways through interlaced ideologies and discourse circulating in society," and is of particular relevance within the context of gender, and masculinity in particular (Dasgupta 2013, 7).

Due to Japan's rapid economic growth from the 1950s, combined with the social normalisation of nuclear families and an increase in domestic consumer goods such as vacuum cleaners and refrigerators, the private/female and public/male binary continued in post-war society, helping to standardise the salaryman archetype (Uno 1993). Embodying "loyalty, diligence, dedication, and self-sacrifice" (Dasgupta 2003, 123), the salaryman was not only required to perform well in the workplace but also conform to the requirements of hegemonic heterosexuality, such as marriage, children and financial provision for his family (Kelly 1993, 208-15). As Japan transformed into a late-capitalist society, however, welfare state conditions were pared back as the economy entered recession in the mid-1980s, and many middle-aged salarymen were retrenched (Dasgupta 2013, 130-31). By the late 1990s, Japan was in the middle of an economic meltdown. With economic stagnation,

.


employers revoked conditions of lifetime employment and seniority-based remuneration. Employees felt betrayed by the corporations in which they had invested so much of their lives, and the masculine ideal of the main breadwinner that had continued throughout post-war Japan became less and less an achievable reality. In this socio-economic climate, the soshokukei danshi (草食系男子; 'herbivore man') emerged as an alternative to salaryman masculinity. Characterised as "professionally unambitious, consumerist, and passive or uninterested in heterosexual romantic relationships" (Charlebois 2013,89 ), these men are seen as "less willing to take chances in their lives due to an anxiety-laden and unforeseeable future" (Suganuma 2015, 94).

Following the general erosion of the hegemonic salaryman masculinity as an obtainable ideal, Matanle et al. (2008) assert that "salaryman manga offers a powerful cultural marker for urban Japanese males seeking to maintain their masculine self-identities within the confusion and insecurity of the contemporary Japanese business organisation" (645). While Sarariiman Kintarō "provides opportunities for salarymen to enact strategies for surviving and thriving under the pressures of working in contemporary Japanese business organisations" (Matanle et al. 2008, 660), Hatarake, kentaurosu! does not seek to instruct or motivate the modern salaryman. By targeting a female audience of BL-literate readers, it offers a critique of the compulsorily heterosexual, hegemonic masculinity of the corporate warrior. Instead of embodying the qualities of alternative sōshokukei danshi masculinity, however, Kentarō

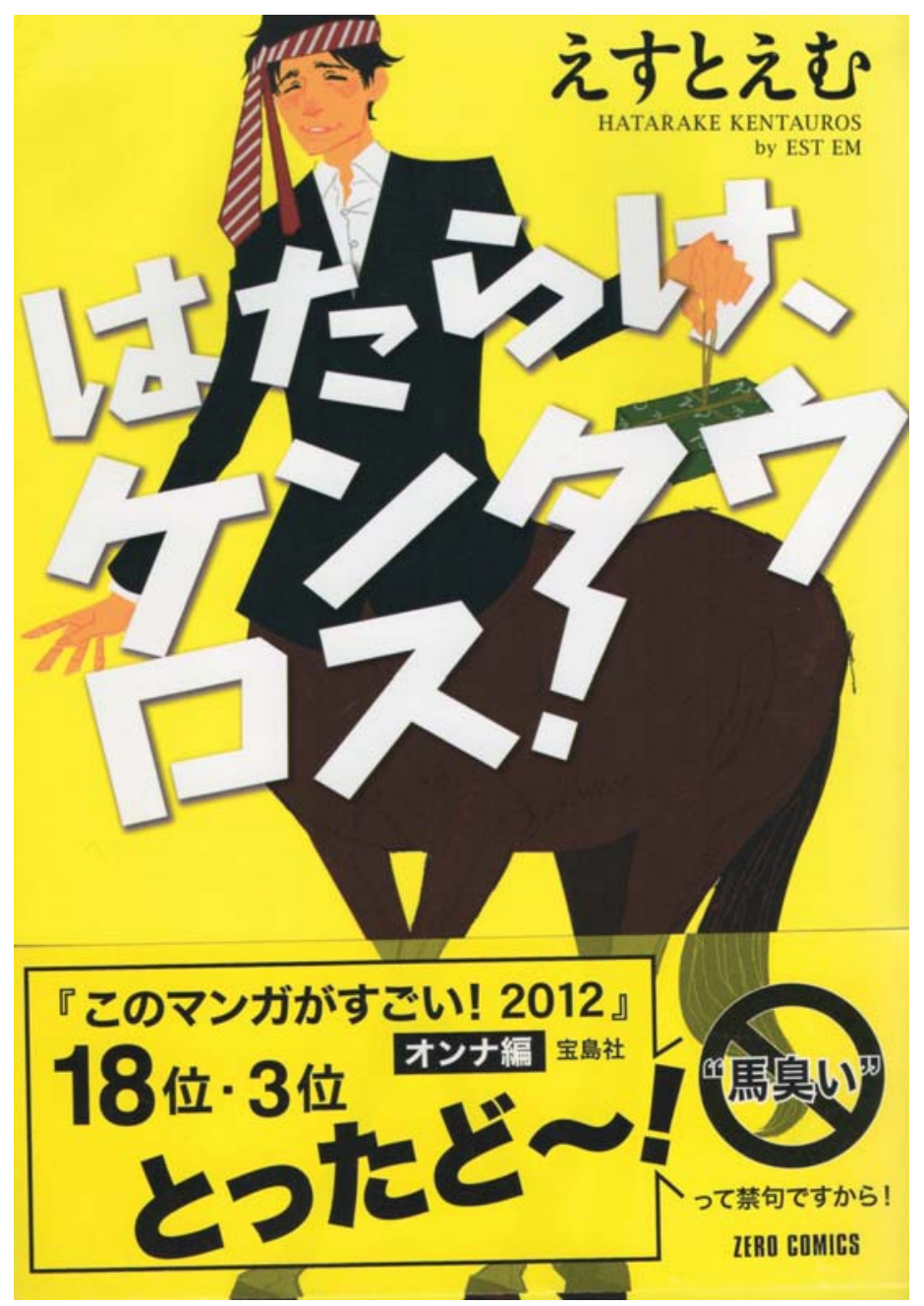

Figure 1: Kentarō on the cover of Hatarake, kentaurosu! (c) esutoemu 2011. Reproduced with permission. 
represents an ideal salaryman: he is well groomed, diligent and places his coworkers' needs before his own. However, simply because Kentarō's lower body is that of a horse rather than a human, it is impossible for him to represent the hegemonic ideal. This duality allows him to conform to certain aspects of hegemonic salaryman masculinity while remaining separated from others, much like female readers themselves.

The cover of Hatarake, kentaurosu! illustrates this juxtaposition by depicting Kentarō wearing a suit jacket with rosy cheeks and a tie around his head, signifying drunkenness. His bottom horse half is also clearly visible, forelegs twisted. The volume's obi (帯), a slip of paper wrapped around the cover containing additional information about the text, reads "don't say 'horse smell’” (“馬臭い”って禁句ですから!). While the scent of alcohol on Kentarō’s breath may be accepted as a rite of passage for an overworked businessman, remarking on the "horse smell" of a centaur is considered offensive and embarrassing, exemplifying different codes of manners between humans and centaurs. The first page then features a colour illustration of the everyday necessities Kentarō carries in his bag and pockets. All are items that might be found in any salaryman's briefcase, aside from a thick brush for the horse half of Kentarō's body. This playful twist on a hair brush is a humourous inclusion for female readers who might carry something similar in their own bags. Representing the other while still embodying all of the traditional traits marking a model salaryman, Kentarō's character parodies the closed male homosocial workplace for female readers in a fun and pleasurable manner.

\section{PLEASURE AND PLAY IN EQUUS}

Unlike Hatarake, kentaurosu!, the stories in equus, with its two bishōnen (美少年; lit., 'beautiful boy') centaurs on the cover (see Figure 2), are explicitly focused on romantic and sexual interactions. ${ }^{11}$ Named after the genus of mammals that includes horses and published in May 2011, equus is a collected work of short stories previously published by est em as dojjinshi (同 人誌), which are non-commercial manga publications produced by amateur artists and manga fans, and usually distributed at conventions and other fan gatherings. equus was included as one of the top BL titles of 2011 in the annual book Kono BL ga yabai! ('This BL is awesome!'), suggesting that est em's malemale centaur eroticism resonated with BL readers (NEXT Henshūbu 2012). However, readers looking for the explicit erotic content prevalent in many BL may have been surprised to find the stories in equus to be more focused on emotion, rather than sexual gratification. est em herself has stated that the stories collected in equus consider how "humans and centaurs affect one another” (人とケンタウロスがどう関わるか) (est em 2011a, 7).

In equus, each chapter is named after the coat colour of the centaur central to that chapter's narrative. Aside from "Dun Black," which features a narrative spanning three chapters, each short story is a self-contained vignette. The relationships between man and centaur depicted in these stories are distinctly homoerotic in nature and tend to be much more serious than those contained 


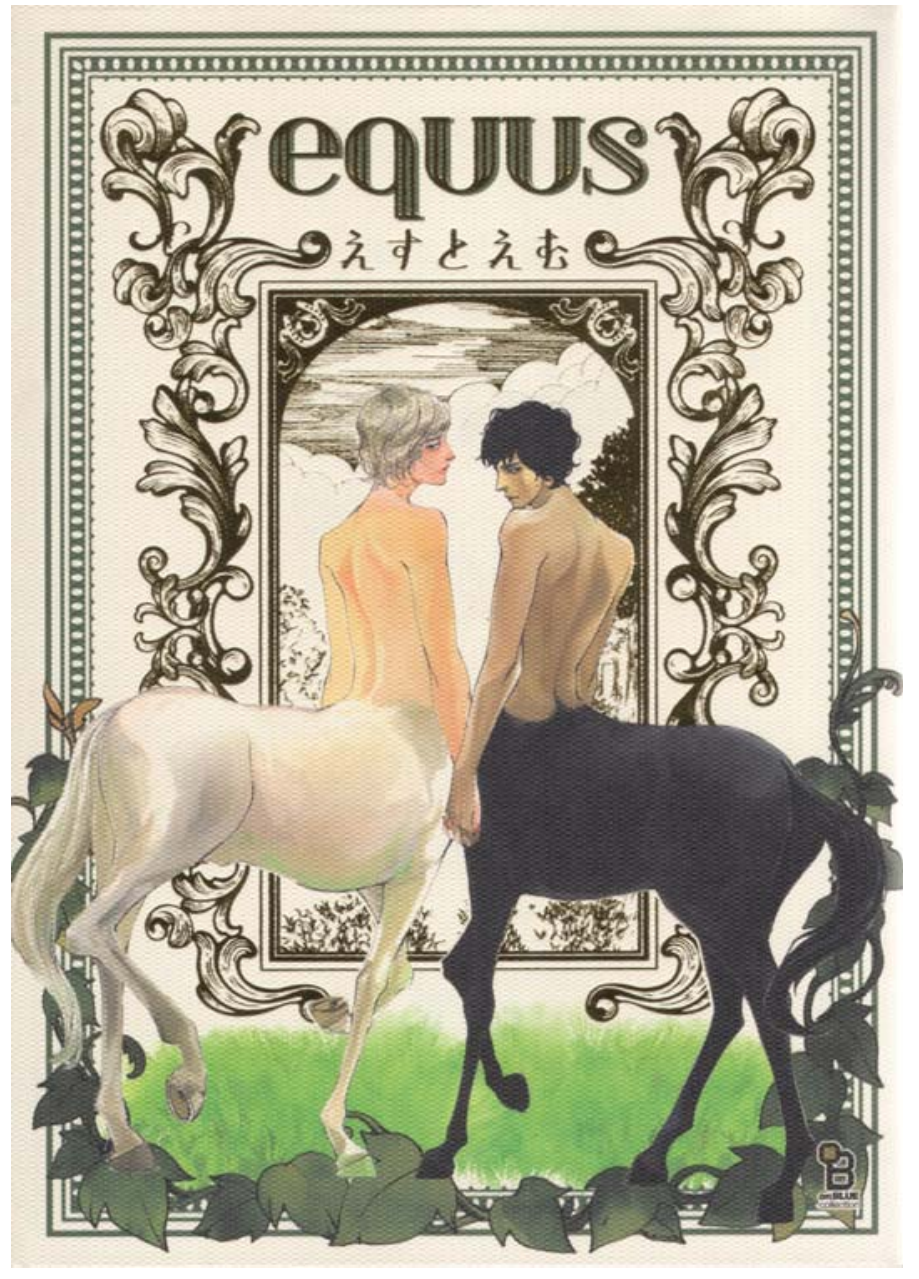

Figure 2: The cover of equus, with an ornate bishonen aesthetic.

(c) est em/Shodensha onBLUE comics. Reproduced with permission.

in Hatarake, kentaurosu!. Rather than exclusively taking place in modern-day Japan, the settings of equus range from Europe to historical Japan. As Mark McLelland (2000) and others have observed, shōjo manga of the late 1960s and 1970s often featured exotic locations, allowing artists to explore themes such as male-male desire that would have been considered taboo in early postwar Japan (see also Prough 2010). This "anti-realism" was established by setting narratives in locations outside of Japan, such as Europe or America (McLelland 2000, 18). In equus, the most sexually explicit chapters take place in undefined European locations, much like early shōnen ai manga such as Keiko Takemiya's Kaze to ki no uta ['The Song of Wind and Trees'; 1976]. Just like Takemiya, est em approaches the taboo subject of male-male centaur eroticism by setting the most explicitly homoerotic of these narratives in Europe, rather than Japan.

est em's equus also shares its title with Peter Shaffer's famous 1973 play, Equus. Set in England and inspired by a real incident, Shaffer's play delves into the psychology behind a 17-year-old boy named Alan who blinds six horses in a horrific crime. The play is told from the perspective of the boy's psychiatrist, an ageing, dissatisfied man who find himself enthralled by the boy's intense spiritual commitment to his worship of horses. While this is not a preoccupation in est em's stories, it is significant that she chose this title for her BL centaur collection, rather than the shōjo manga Hatarake, kentaurosu!. 
Significantly, Shaffer's play deals with Alan's sexual attraction to horses, particularly a male chestnut called Nugget. Alan's intense worship of the horse god Equus culminates in him wishing to become one with a horse, which he achieves by riding Nugget naked and bareback in the dead of night. What is treated as abhorrent in Equus, however, is transformed into the comic/erotic in est em's equus. In one short story, titled "Chestnut," a bareback riding scene similar to that featured in Equus transforms the one-sided intimacy Alan feels with Nugget to a mutual bonding romance. The ironic culmination of the young man mounting the centaur for the first time is not ecstasy, however, but an allusion to safe sex, where the centaur urges the rider to put on a helmet for safety (est em 2011b). In "Black and White," a human rider is bucked from his chestnut horse while riding through a forest (2011b, 35). Upon investigation, the man discovers that the horse was spooked by the presence of two naked men. However, it is quickly revealed that the men are not human, but rather centaur lovers. Fascinated by his first time seeing centaurs in the wild, the rider remains fixated on the pair as they kiss see (Figure 3). Noticing the staring rider, the centaurs playfully invite him to join them. The resulting centaurman-centaur threesome can be read as an amusing twist on the "strange" erotic fixation that Alan has with horses in Shaffer's play. Instead of disgust and discomfort, est em's sensual lines and wordless panels evoke a sense of longing, intimacy and eroticism between the man and the centaurs.

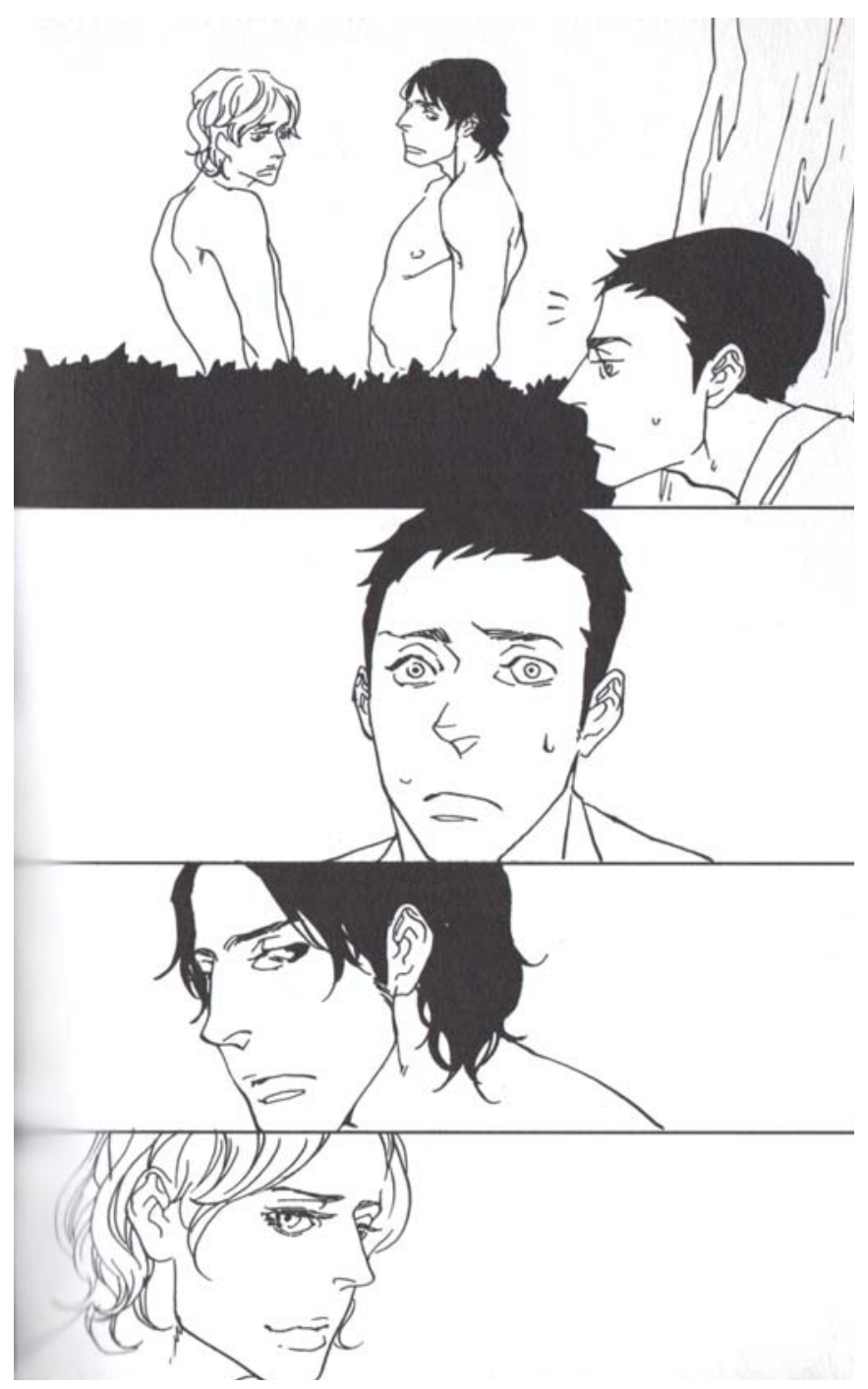

Figure 3: A human rider silently admires two centaur lovers in a forest, from equus. (C) est em/Shodensha onBLUE comics. Reproduced with permission. 
Although est em's focus is not on horses per se, the centaur men in est em's manga derive from the half-human, half-horse hybrid familiar to Western culture. These centaur men are undoubtedly 'other', and face many of the same issues that real-word minorities such as gay men in Japan experience. They require separate traffic lanes to run in, their own bathrooms and modified dwellings. In Hatarake, kentaurosu!, centaurs have long coexisted with humans, but have only just been granted legal rights. Perhaps drawing from their liminal position between mortals and gods in Greek mythology, est em's centaurs' metabolisms are also significantly different from that of humans-not only do they require more food throughout the day to provide energy for their horse halves, but they also live for centuries, only reaching maturity at the age of 50. Perhaps an ironic commentary on Japan's ageing society, Kentarō of Hatarake, kentaurosu! is already older than many of his superiors at work despite being a new hire, and will go on to outlive all of his human colleagues.

Age as a major difference between humans and centaurs is a recurring theme in both equus and Hatarake, kentaurosu!. In "Dun Black," a Japanese college student is shocked to learn that his centaur classmate has no idea how long his kind lives because he does not know anyone who has seen one die (est em 2011b, 5). In one of the more poignant stories in Hatarake, kentaurosu!, we see firsthand the impact that centaurs' long lifespans have on their relationships with humans. A centaur who becomes a shoemaker due to his love of human shoes is shocked when he learns that his employer will leave his position once he is married. In a romantic comedy cliché, he bursts into the church to object to the marriage and proceeds to whisk his employer away on his back, saving him from a dull life with a woman he is not attracted to. Like Kentarō and his unnamed colleague, BL literate readers will undoubtedly view this pair as being intimately involved beyond their working relationship. As if lovingly depicting a couple growing old together, est em shows the human man ageing over the course of four panels until he is no longer present in the frame, while the centaur remains exactly the same (see Figure 4).

Another story to focus heavily on the slowed centaur ageing process is "Bay Silver," which features a centaur slave who is passed down through three generations of human male owners over the course of three chapters. As his former master and lover lies on his deathbed, the always-youthful centaur agrees to look after the man's son and is given a name for the first time in his life (est em 2011b, 111). This master/servant relationship that passes down from father to son is also a central theme of another BL manga, Shitsuji no bunzai ['A Butler's Place'; 2005] by Fumi Yoshinaga. In both Shitsuji no bunzai and "Bay Silver," the master/servant relationship becomes more intimate as the servant/slave is taught to read (Aoyama 2012, 74). Just as reading is a subversive act for the readers of equus, reading allows the characters of Shitsuji no bunzai and equus to break out of traditional social roles. Intimate scenes such as these also enable readers to better empathise with individual centaurs, and thus more acutely relate to the issues of alienation and inequality explored within these texts. 


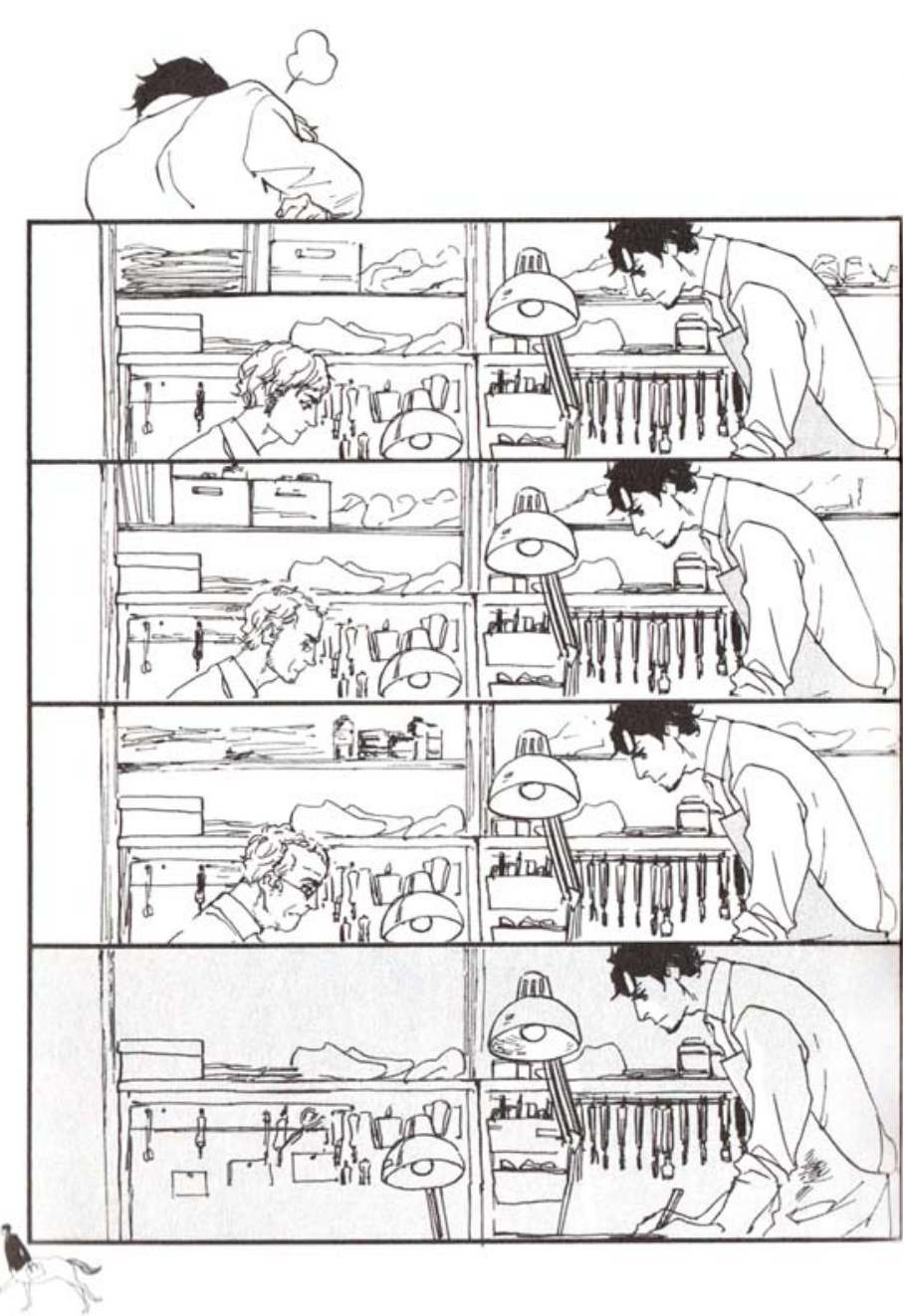

Figure 4: A four-panel depiction of the different rates of ageing between humans and centaurs, from Hatarake, kentaurosu!. (c) esutoemu 2011. Reproduced with permission.

This focus on individual characters, while simultaneously highlighting the ways in which centaurs are both similar to and different from their human counterparts, is especially prominent in a chapter of Hatarake, kentaurosu! titled "Moderu" (モデル; model). In this story, an unnamed centaur model is fed up with his agency editing his photos so that no one will know he is a centaur (est em 2011c). When his latest ad campaign is unveiled, two fans can't believe that he looks the same as he did over ten years ago, joking that he must be an android or heavily airbrushed. Humorously, the image has been edited, but not in the way they imagine. As a centaur, the model ages at a much slower pace than humans, so rather than his age, it is his physical difference that is being concealed from the public. In a minor but moving use of intertextuality, the model bitterly compares himself to the little mermaid who sacrifices her voice for a pair of human legs before finally quitting his agency. Soon afterward, however, the model is approached by a designer who wants to debut his new collection on the runway with a centaur. Focusing on 'original beauty,' the collection highlights the model's centaur form (see Figure 5), and the resulting advertising campaign inspires a new horseshoe trend among centaurs. While the themes of alienation and embracing one's unique beauty present in this story are not unfamiliar concepts to readers, they are amplified through the use of centaur, rather than human, characters. 

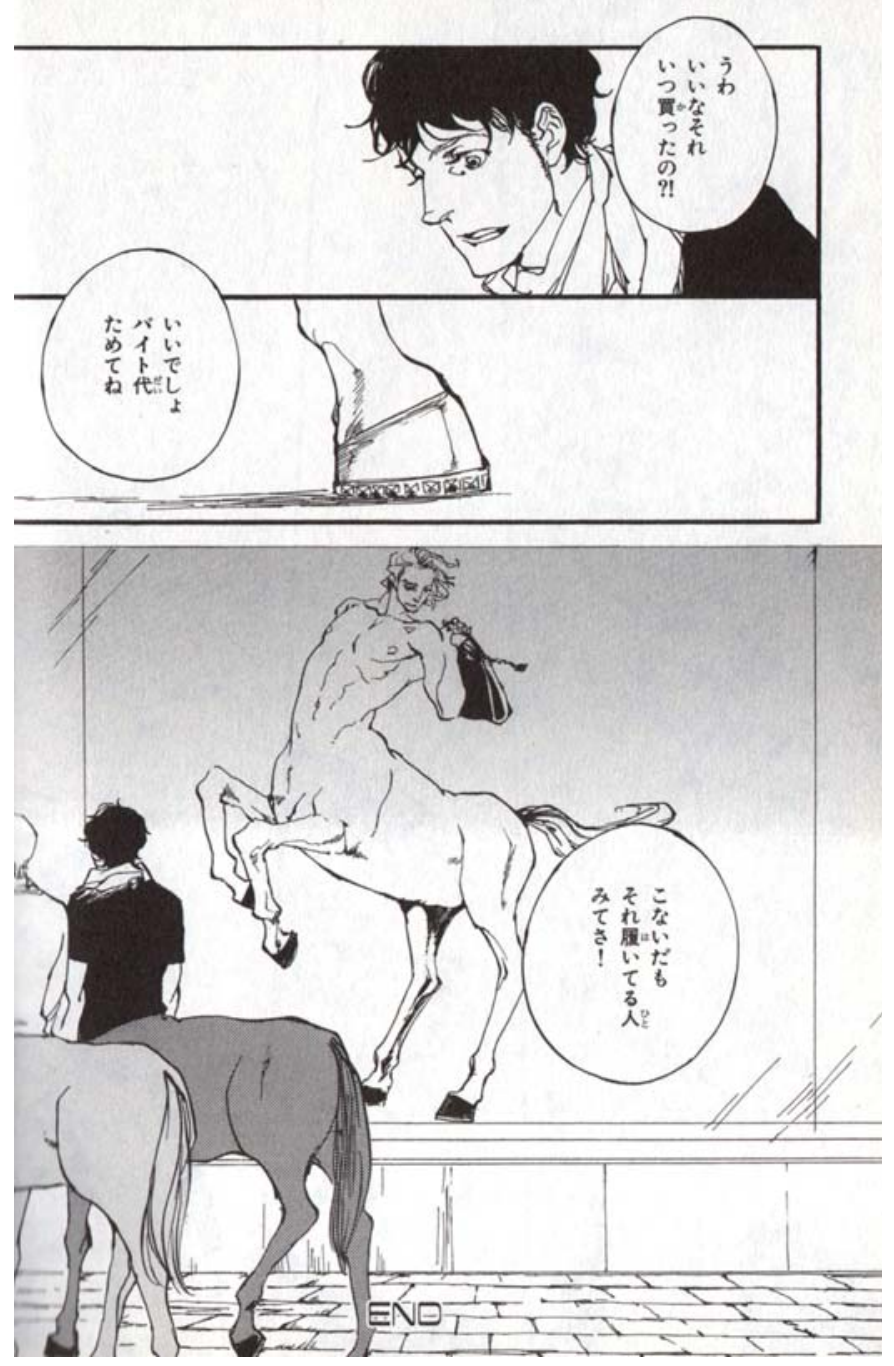

Figure 5: Centaurs admiring a beautiful centaur model, from Hatarake, kentaurosu!. (C) esutoemu 2011. Reproduced with permission.

\section{CONCLUSION}

Through the use of centaurs in equus and Hatarake, kentaurosu!, est em's manga present subtle critiques of existing gender and social structures. Female readers are invited to enjoy the play of intertextual parody within these texts, while at the same time deconstructing the traditionally homosocial world of the salaryman and engaging with themes of otherness. The freedom to explore alternatives to hegemonic masculinity and patriarchal structures by which the readers themselves are bound may not enable immediate or lasting change. But even so, reading itself is a subversive act where anything is possible. As Aoyama notes, "Rather than directly protesting patriarchal and heterosexist oppression, contemporary BL artists and readers seem to transform existing inequalities and potential threats into pleasure and gratification" $(2012,66)$. By referencing shared cultural motifs-from Sarariiman Kintarō to Hashire Merosu-est em encourages shōjo and BL readers to laugh at the intertextual pleasures of these male-dominated texts. Meanwhile, the male-male centaur romances in equus fulfil the desire for erotic BL narratives while also transforming the kind of one-sided devotion found in Peter Shaffer's Equus into mutual, consensual pleasure. In doing so, est em's centaur manga challenge existing constructs of normative heterosexuality and hegemonic masculinity while encouraging readers to enjoy the pleasures of homoerotic centaurs. 
Disclaimer: The artist (est em) and the publisher of Hatarake, kentaurosu! (Libure Shuppan) do not necessarily endorse the reading presented in this paper.

\section{APPENDIX: BIBLIOGRAPHY}

\begin{tabular}{|c|c|c|c|c|c|c|c|c|c|c|c|c|c|c|c|c|c|c|c|c|c|c|}
\hline 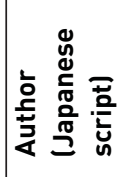 & 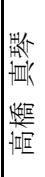 & & 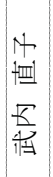 & & 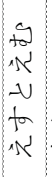 & $\begin{array}{l}x \\
\text { 超 } \\
\text {. }\end{array}$ & 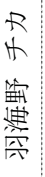 & $\begin{array}{l}\text { 保 } \\
\text { 期 } \\
K\end{array}$ & $\begin{array}{l}\text { ta } \\
\text { Nर } \\
\text {-v } \\
\text { th } \\
\text { s. }\end{array}$ & 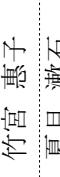 & & 1 & & $\frac{F}{R}$ & 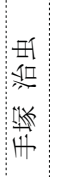 & 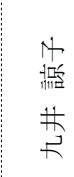 & 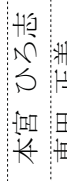 & 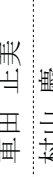 & 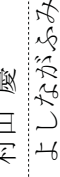 & $\begin{array}{l}\text { की } \\
\text { Nर } \\
\text {-u } \\
\text { to } \\
\text { N }\end{array}$ & & 厌 \\
\hline 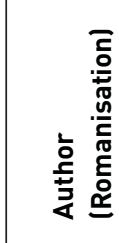 & 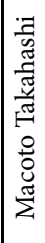 & & 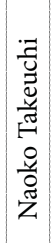 & & 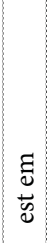 & 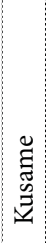 & 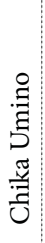 & 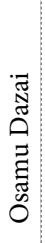 & $\begin{array}{l}\tilde{\Xi} \\
\frac{5}{\delta}\end{array}$ & 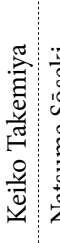 & & & & 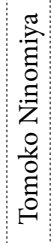 & 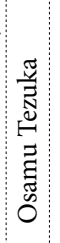 & 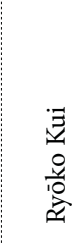 & 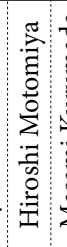 & 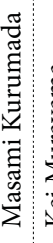 & 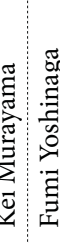 & & & 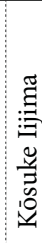 \\
\hline 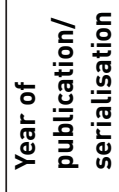 & $\stackrel{\substack{\infty \\
ٌ}}{\alpha}$ & ఫ̊ & $\vec{a}$ & & $\overrightarrow{\tilde{N}}$ & $\stackrel{\infty}{\circ}$ & ڤ্ণ & 윰 & $\overrightarrow{\text { ปे }}$ & $\stackrel{2}{2}$ & & & 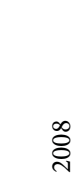 & ठे & $\stackrel{2}{2}$ & $\vec{\nabla}$ & & 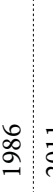 & ț & ఫ্ণ & & 류 \\
\hline 离 & 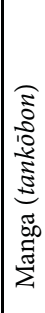 & 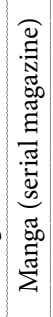 & 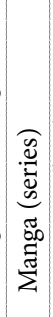 & 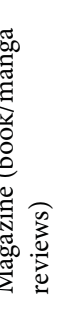 & 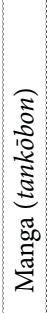 & 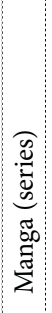 & 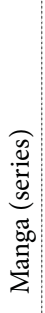 & की & 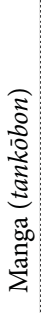 & 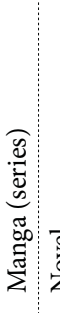 & & 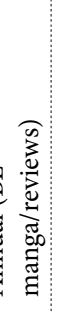 & 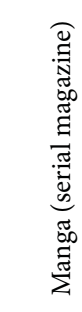 & 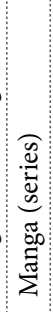 & 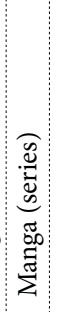 & 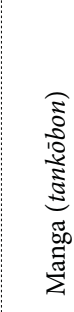 & 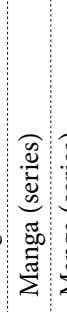 & 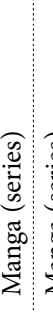 & 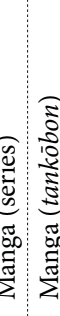 & 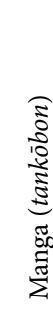 & 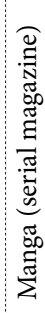 & 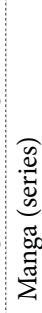 \\
\hline 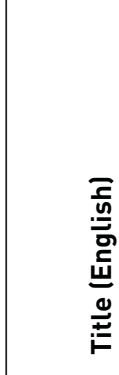 & 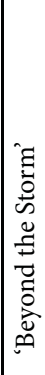 & $\begin{array}{l}0 \\
0 \\
0 \\
0 \\
\vdots \\
0 \\
0 \\
0 \\
10 \\
\infty\end{array}$ & 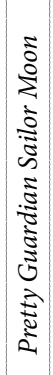 & $\begin{array}{l}\overline{\tilde{G}} \\
\dot{\Xi} \\
\tilde{\Xi}\end{array}$ & 意 & 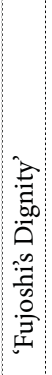 & 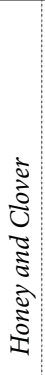 & 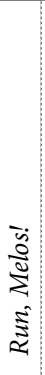 & 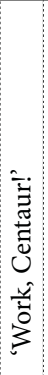 & 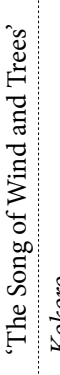 & & 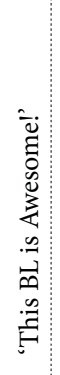 & 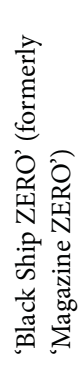 & 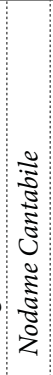 & 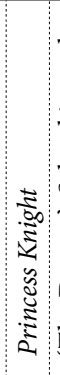 & 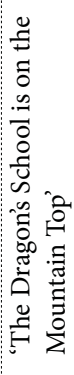 & 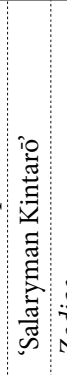 & 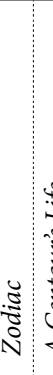 & 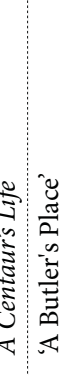 & 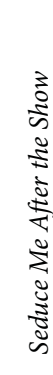 & 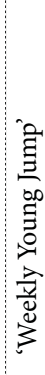 & $D_{0}$ \\
\hline 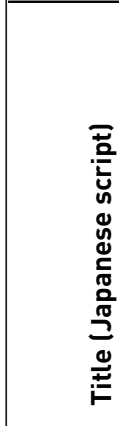 & 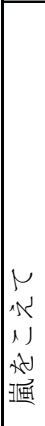 & 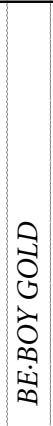 & 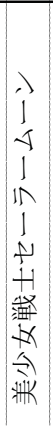 & 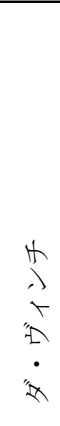 & $\begin{array}{l}\kappa \\
\hat{L} \\
\hat{H}\end{array}$ & 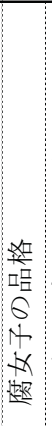 & 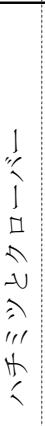 & 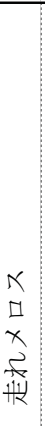 & 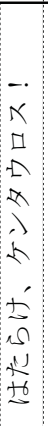 & 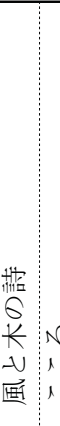 & & 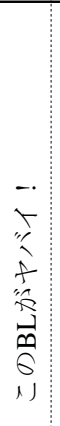 & 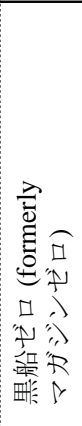 & $\begin{array}{l}\overrightarrow{1} \\
1 \\
1 \\
\hat{\lambda} \\
\hat{2} \\
2 \\
0 \\
0 \\
6\end{array}$ & 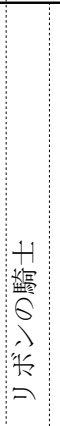 & 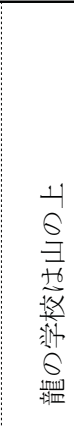 & 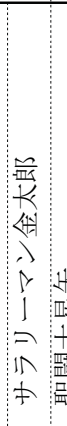 & 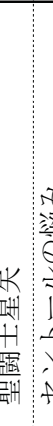 & 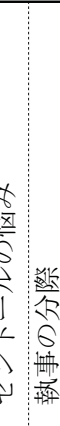 & 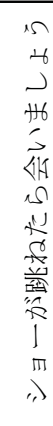 & 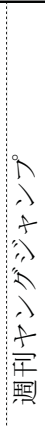 & \\
\hline 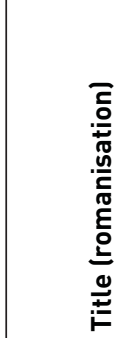 & 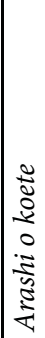 & 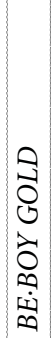 & 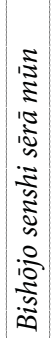 & 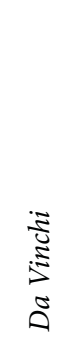 & & $\begin{array}{l}3 \\
3 \\
0 \\
3\end{array}$ & 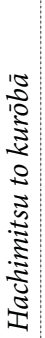 & בै & 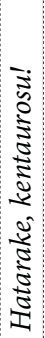 & 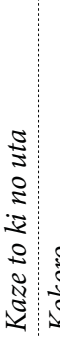 & & 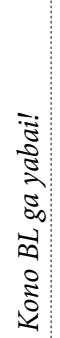 & 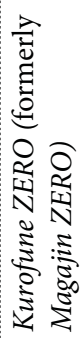 & $\begin{array}{c}0 \\
\frac{2}{2} \\
\frac{1}{2} \\
\frac{2}{2} \\
2 \\
\frac{2}{2} \\
\frac{5}{2} \\
z\end{array}$ & $\begin{array}{c}1 \\
\frac{3}{3} \\
\frac{3}{2} \\
\frac{1}{2} \\
\frac{1}{2} \\
\frac{2}{2}\end{array}$ & 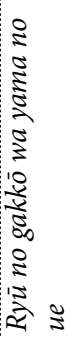 & 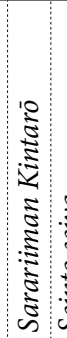 & 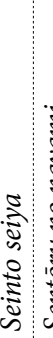 & 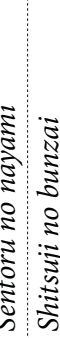 & 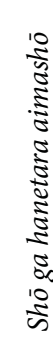 & 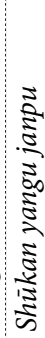 & \\
\hline
\end{tabular}




\section{GLOSSARY}

\section{bishōnen (美少年)}

lit., 'beautiful boy'; refers to the youthful beauty of adolescent boys and young men celebrated in Japanese culture as far back as the Heian period [794-1185]

$\mathrm{BL}$

see boizu rabu

boizu rabu (ボイズラブ)

lit., 'boys' love'; a genre of manga featuring male-male romance between adolescent boys/adult men marketed towards teenage and young adult women, often containing sexual content. Frequently shortened to 'BL'. This term is distinct from shōnen ai, which refers explicitly to male-male romance manga that was marketed towards teenage and young adult women during the late 1960s and 70s.

\section{bōsōzoku (暴走族)}

lit., 'speed tribe'; Japanese youth subculture associated with motorcycle customisation

\section{dōjinshi (同人誌)}

non-commercial manga publications produced by amateur artists and manga fans, usually distributed at conventions and other fan gatherings

dōseiai (同性愛)

lit., 'same-sex love'. This term came to replace nanshoku (男色; also read as 'danshoku', meaning 'male eros') and shudōwakashudo (衆道・若衆道; the way of the youth) during the Meiji period [1868-1912]

\section{fujoshi (腐女子)}

lit., "rotten girl,"; originally used as an insult to denote women who read BL manga, now used by BL fans as both a playful and self-derisive descriptor

genpuku/genbuku (元服)

classical male coming-of-age ceremony

nanshoku/danshoku (男色)

lit., 'male eros'; used to describe male-male desire during the Edo period [1603-1868]. See also shudō/wakashudō

nioi-kei (臭い系)

comprised of the word 'nioi' (臭い; smell) and the colloquial suffix '-kei' (系; kind/ subgroup/type); used to identify texts that demonstrate a hint or 'whiff' of BL to BLliterate readers

obi (帯)

lit., 'belt', 'sash'; used in the publishing industry to denote the small paper wrappers on book and CD covers containing additional information about the contents

sashie (挿絵)

illustrations

manga marketed towards young adult to adult men 
shōjo manga (少女漫画)

manga marketed towards junior high and high school girls

shōjo shōsetsu (少女小説)

girls' novels

shōnen ai (少年愛)

lit. "boys' love,"; refers to early male-male romance manga (circa late 1960s-70s)

aimed at a female audience

shōnen manga (少年漫画)

manga marketed towards junior high and high school boys

sōshokukei danshi (草食系男子)

lit., 'herbivore man'; a colloquial term that refers to young adult men who are uninterested in professional advancement and heterosexual romantic relationships

shudō/wakashudō (衆道・若主導)

lit. "way of the youth," used to describe male-male desire during the Edo period [1603-1868]. See also nanshoku.

\section{tankōbon (単行本)}

an independent or standalone book (not part of a series). Manga tankōbon are often collections of chapters previously serialised in manga magazines

ukiyoe (浮世絵)

lit. 'pictures of the floating world'; woodblock prints that were popular during the

Edo period [1603-1868]

\section{REFERENCES}

Aoyama, T. 1992. "The Antinationalist Movement in Japan Circa 1910.” PhD Thesis. University of Queensland.

1994. "The Love that Poisons: Japanese Parody and the New Literacy." Japan Forum 6 (1): 35-46.

. 2012. "BL (Boys' Love) Literacy: Subversion, Resuscitation, and Transformation of the (Father's) Text." U.S.-Japan Women's Journal 43: 63-84.

Aoyama, T. and B. Hartley. 2010. "Introduction." In Girl Reading Girl in Japan, edited by T. Aoyama and B. Hartley, 1-14. New York: Routledge.

Angles, J. 2011. Writing the Love of Boys: Origins of Bishōnen Culture in Modernist Japanese Literature. Minneapolis: University of Minnesota Press.

Barthes, R. 1973. The Pleasure of the Text. Translated by R. Miller. New York: Hill and Wang.

Charlebois, J. 2013. "Herbivore Masculinity as an Oppositional Form of Masculinity." Culture, Society, \& Masculinities 5 (1): 89-104. http://dx.doi.org/10.3149/ CSM.0501.89 
Cixous, H. 1976 [1975]. “The Laugh of the Medusa” [La Rire de la Méduse]. Translated by K. Cohen and P. Cohen. Signs 1: 875-99.

Connell, R. W. 1987. Gender and Power: Society, the Person and Sexual Politics. Cambridge: Polity Press.

Dasgupta, R. 2003. “The 'Salaryman' and Masculinity in Japan.” In Asian Masculinities: The Meaning and Practice of Manhood in China and Japan, edited by K. Louie and M. Low, 118-34. London and New York: Routledge.

2013. Re-Reading the Salaryman in Japan: Crafting Masculinities. New York: Routledge.

Eagleton, T. 1983. Literary Theory: An Introduction. Oxford: Blackwell Publishing.

est em [えすとえむ]. 2011a. “Anata no shiranai esu to emu” [あなたの知らない えすとえ む] . On BLUE [オンブルー] 2, Spring, 3-27. Tokyo: Shōdensha [祥伝社].

[ [えすとえむ]. 2011b. equus [エクウス]. Tokyo: Shōdensha [祥伝社].

. [えすとえむ]. 2011c. Hatarake, kentaurosu! [はたらけ、ケンタウロス!]. Tokyo: Libure Shuppan [リブレ出版].

Fujimoto, Y. [藤本 由香里]. 1998. Watashi no ibasho wa doko ni aru no?: Shōjo manga ga utsusu kokoro no katachi [私の居場所はどこにあるの? :少女マンガが映す 心のかたち]. Tokyo: Gakuyō Shobō [学陽書房].

Fujimoto, Y. 2012. “Takahashi Macoto: The Origin of Shōjo Manga Style.” Translated by M. Thorn. Mechademia 7: 24-55.

Honda, M. 2010. “The Genealogy of Hirahira: Liminality and the Girl.” In Girl Reading Girl in Japan, edited by T. Aoyama and B. Hartley, 19-37. London and New York: Routledge.

Hutcheon, L. 1985. A Theory of Parody: The Teachings of Twentieth-Century Art Forms. New York: Methuen, Inc. 2006. A Theory of Adaptation. London and New York: Routledge.

Ishida, M. [石田 美紀]. 2008. Hisoyaka na kyōiku “yaoi/bōizu rabu”zenshi [密やかな 教育＜やおいボイズラブ＞前史]. Tokyo: Rakuhoku Shuppan [洛北出版].

Ito, K. 2005. "A History of Manga in the Context of Japanese Culture and Society." The Journal of Popular Culture 38 (3): 456-75. http://dx.doi.org/10.1111/ j.0022-3840.2005.00123.x

Kan, S. 2010. "Everlasting Life, Everlasting Loneliness: The Genealogy of the Poe Clan.” U.S.-Japan Women's Journal 38: 43-58.

Kaneda, J. [金田 淳子]. 2007. “Yaoi ron, asu no tame ni (sono 2)” [やおい論、明日のため (その2) ]. Yuriika [ユリーカ] 39 (16): 48-54. 
Kelly, W. W. 1993. "Finding a Place in Metropolitan Japan: Ideologies, Institutions, and Everyday Life.” In Postwar Japan as History, edited by A. Gordon, 189216. Berkeley: University of California Press.

Matanle, P., L. McCann and D. Ashmore. 2008. “Men Under Pressure: Representations of the 'Salaryman' and his Organization in Japanese Manga." Organization 15 (5): 639-64. http://dx.doi.org/10.1111/j.0022-3840.2005.00123.x

Matsuoka, N. and S. Miura. 2009. "BL-nō de yomu meisaku bungaku annai” [BL脳で 読む名作文学案内]. Da Vinchi [ダ・ヴインチ] 178, February, 26-30.

McLelland, M. 2000. “The Love Between 'Beautiful Boys' in Japanese Women's Comics." Journal of Gender Studies 9 (1): 13-25. http://dx.doi.org/10.1111/ j.0022-3840.2005.00123.x

McLelland, M. and J. Welker. 2015. "An Introduction to 'Boys Love' in Japan." In Boys Love Manga and Beyond: History, Culture, and Community in Japan, edited by M. McLelland, K. Nagaike, K. Suganuma and J. Welker, 3-20. Jackson: University of Mississippi Press.

Media Factory. 2009. "Da Vinchi dokusha ga eranda nioi-kei meisaku bungaku besuto 3” [ダ・ヴィンチ読者が選んだ臭い系名作文学ベスト3]. Da Vinchi [ダ・ヴ インチ] 178, February, 28.

Mizoguchi, A. 2010. "Theorizing Comics/Manga as a Productive Forum: Yaoi and Beyond." Comics Worlds and the World of Comics: Towards Scholarship on a Global Scale, edited by J. Berndt, 143-168. Kyoto: International Manga Research Center, Kyoto Seika University.

NEXT Henshūbu [NEXT 編集部]. 2012. Kono BL ga yabai! 2012-nen fujoshi han [この BLがやばい! 2012年腐女子版]. Tokyo: Ōzora Shuppan [宙出版].

O’Brien, J. 1989. “Melos, Run!” In Crackling Mountain and Other Stories, edited by J. O’Brien, 110-126. North Clarendon: Tuttle Publishing.

Padgett, J. M. 2003. The Centaur's Smile: The Human Animal in Early Greek Art. New Haven: Yale University Press.

Pflugfelder, G. M. 1999. Cartographies of Desire: Male-Male Sexuality in Japanese Discourse, 1600-1950. Berkeley: University of California Press.

Prough, J. 2010. "Shōjo Manga in Japan and Abroad." In Manga: An Anthology of Global and Cultural Perspectives, edited by T. Johnson-Woods, 93-105. New York: The Continuum International Publishing Group Inc.

Reeve, C. D. C. 2006. Plato on Love: Lysis, Symposium, Phaedrus, Alcibiades with Selections from Republic and Laws. Indianapolis: Hackett Publishing Company, Inc.

Saito, K. 2011. "Desire in Subtext: Gender, Fandom, and Women's Male-Male Homoerotic Parodies in Contemporary Japan." Mechademia 6: 171-191. 
Sato, I. 1991. Kamikaze Biker: Parody and Anomy in Affluent Japan. Chicago: University of Chicago Press.

Sedgwick, E. K. 1992. Between Men: English Literature and Male Homosocial Desire. New York: Colombia University Press.

Shaffer, P. 1973. Equus. London: Deutsch.

Schodt, F. L. 1983. Manga! Manga! The World of Japanese Comics. New York: Kodansha International.

Suganuma, K. 2015. "Queer Cooking and Dining: Expanding Queerness in Fumi Yoshinaga’s What Did You Eat Yesterday?? Culture, Society, \& Masculinities 7 (2): $87-101$.

Takeuchi, K. 2010. “The Genealogy of Japanese Shōjo Manga (Girl's Comics) Studies.” U.S.-Japan Women’s Journal 38: 81-112.

Ueno, C. [上野 千鶴子]. 1989. “Jendāresu wārudo no 'ai' no jikken-shōnen ai manga $o$ megutte” [ジェンダーレス・ワールドの<愛>の実験一少年漫画をめぐって ]. Toshi [ 都市] 2: 134-43.

Uno, K. S. 1993. “The Death of 'Good Wife, Wise Mother'?” In Postwar Japan as History, edited by A. Gordon, 293-322. Berkeley: University of California Press.

Vincent, K. 2012. Two-Timing Modernity: Homosocial Narrative in Modern Japanese Fiction. Cambridge: Harvard University Asia Center.

Wood, A. 2006. "'Straight' Women, Queer Texts: Boys-Love Manga and the Rise of a Global Counterpublic.” Women's Studies Quarterly 34: 394-414. 


\section{Visualising Shattered Lives: Potentiality in Representations of Rape Victimisation in Contemporary Japanese Cinema}
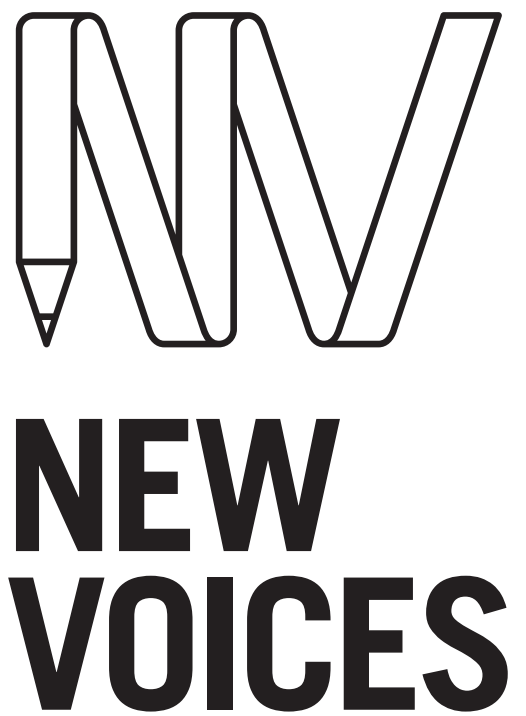

IN JAPANESE STUDIES

\section{HEI-LEI CHENG}

Australian National University

\section{ABSTRACT}

This article examines how cinematic representations of rape can challenge the silence which surrounds the issue of rape and sexual violence in Japan. A textual analysis of two contemporary fictional Japanese films, DV: Domestic Violence [2005] and The Ravine of Goodbye [2013], was performed to illustrate how filmmakers can use narrative and cinematographic techniques to influence the viewer to reflect upon their attitudes to rape and rape victims. By examining how these two films depict rape and rape recovery, this article argues that there is discursive potential inherent within cinema to shape our imaginations and ideals about the world. But while the filmmaker can construct rape representations that encourage reflection, how the viewer decides to engage with the film has bearing on whether this potential for reflection is realised.

\section{KEYWORDS}

cinema; criminality; domestic violence; film; gender; rape; representation; women; sexual violence; spectatorship

\section{JAPANFOUNDATION 8 \\ BRINGING JAPAN TO YOU \\ To link to this article: \\ http://dx.doi.org/10.21159/nvjs.08.04}

ISSN 2205-3166

New Voices in Japanese Studies is an interdisciplinary, peer-reviewed journal showcasing the work of emerging scholars from Australia and New Zealand with research interests in Japan.

All articles can be downloaded free at $\underline{\text { newvoices.org.au }}$

(c) The Japan Foundation, Sydney and Hei-Lei Cheng, 2016

\section{(c) $(9)$}

This work is licensed under a Creative Commons Attribution-NonCommercialNoDerivatives 4.0 International License. 


\section{INTRODUCTION}

Stories have a remarkable power to influence and transform a viewer's realworld beliefs while immersing them in a fictional context. From stories, we pick up ideas and ideals about the world and our place within it; through stories, we spread these ideas and ideals into the world. This article explores how representations of rape in film can potentially encourage a shift in the way that individuals perceive sexual violence. Using a textual analysis of two contemporary fictional Japanese films, DV: Domestic Violence [DV:ドメステ イック・バイオレンス; 2005] and The Ravine of Goodbye [さよなら渓谷; 2013], I argue that cinematic representations of rape and rape recovery can help break the relative silence around rape in Japan. Films that represent the issue of sexual violence with the necessary sensitivity can help deepen viewers' understandings of this issue and build empathy in society for rape victims. This article specifically examines representations of female victims of male perpetrated rape; while other forms of sexual violence-such as female-onmale rape, female-on-female rape and male-on-male rape-are also depicted in Japanese cinema, discussion of these representations is beyond the scope of this article.

Representations of rape in popular culture is a topic that has fuelled divisive discussions and strong reactions within public and academic circles. In recent years, increasing numbers of feminist commentators have discussed the issue, concentrating primarily on two main points: 1) the prevalence of sexual violence in popular culture media, and 2) the nature of these depictions. Their concerns are with how the ubiquity of rape representations has naturalised images of sexual violence against women within the general populace (Higgins and Silver 1991; Projansky 2001). While professional critics are also active in this area, the bulk of the commentary comes increasingly from grassroots feminists writing on mass media and popular culture. In English-speaking nations, the emergence of websites and communities such as The Mary Sue and Bitch Media has offered women a space to express anger and frustration at stereotypical depictions of rape and sexual violence, and to call for more accurate and diverse representations. These criticisms are largely based on their own personal experiences. Utilising the internet to make their voices heard, their conversations spread rapidly into the general public and extend beyond a discussion of popular culture to pose broader questions about sexual violence in society.

In Japanese society, however, there is noticeably less critical engagement with rape representation in popular culture media, and the resulting discussion on the broader problem of sexual violence is also absent. I hope that engaging with such representations can help to facilitate important conversations on the topic of sexual violence in Japan, as well as broader discussion on popular culture and its role in motivating social change. By examining how cinematic depictions of the realities of rape and rape recovery can stimulate empathy for rape victims, I will discuss two key points crucial for this transformative potential to be realised: 1) how the filmmaker depicts rape and its aftermath, and 2) whether the viewer chooses to critically respond to the discursive potential in the text.

$$
\text { potentialin the text. }
$$




\section{Japan and Sexual Violence}

Firstly, it is important to understand the culture of silence that surrounds the issue of sexual violence within Japanese society. Between 2011 and 2015, the number of reported cases of rape each year was under 1,500 (NPA 2016, 5). However, research suggests that the actual statistics are much higher, as many victims do not officially seek help or report the crime. In a survey by the Gender Equality Bureau Cabinet Office (2014), 67.5\% of participants who identified themselves as rape victims did not consult anyone after their attack. In Japan, victims do not report rape for a number of reasons, including fear of threats and further violence from the perpetrator, feelings of embarrassment and shame, and the belief that discussing the attack is pointless (Burns 2005; Gender Equality Bureau Cabinet Office 2014). Although government services and women's groups continue to raise public awareness of services available for rape victims and encourage victims to seek official support, victims' reluctance to report rape contributes to the culture of silence that surrounds sexual violence at an individual and societal level (Buckley 1997; Burns 2005; Kaino 2005; Sawada 2010).

Furthermore, feminists and human rights activists have criticised Japan's laws around rape for the rigid barriers it puts before victims seeking legal justice. In her examination of rape court cases in Japan, Catherine Burns (2005) argues that cases are treated differently depending on the characteristics of the attack. Cases that conform to dominant perceptions of rape, such as stranger rape, are seen as " $t s \bar{u} j \overline{0}$ " (通常; regular), and are more likely to achieve a successful prosecution $(2005$, 4). However, cases that do not fit this perception, such as acquaintance rape or marital rape, are considered “fushizen” (不自然; abnormal, unacceptable) and are "consistently distrusted, dismissed or not heard at all" $(2005,4)$. By not conforming to the stereotype of "tsūjō" rape, these latter types of cases place victims' personal lives under greater scrutiny, and the burden of proving violence and sufficient resistance to the attack is much higher (Burns 2005; Yatagawa and Nakano 2008; Asatori and Suzuki 2009). This practice in the Japanese criminal justice system can deter victims from reporting their attack.

While the Japanese legal system has established rape as a criminal wrong and it is also socially recognised as such, silence still surrounds the issue. This is due largely to the following three factors. First, the construction of male sexuality as a natural biological response is used as a rationale to avoid treating rape as a serious social issue. The male body was first likened to a machine by the state in the early Meiji period [1868-1912], and in line with this, sexual gratification was established as a natural impulse and a means to "maintain proper functioning" (McLelland 2005, 36). Takako Konishi (2009) argues that "because rape is still generally accepted as an extension of normal sexual activity, the violence of rape is made invisible” (強姦が通常の性交の延 長にあると考える社会通念のために、行為の暴力性が見えなくなってしまうのであ る。) (81). ${ }^{1}$

Second, sexual relations are generally treated as a private issue within Japanese society's public/private dichotomy. Burns (2005) argues that the

1 All English translations of Japanese source text are by the author. 
construction of "male sexuality" as "natural" in Japan thus "serves to orient male sexual practices in general as private and, therefore, beyond regulation" (54). Although criminalised in the penal code and prosecutable by the state, rape tends to be treated as a private matter (2005). Third, Japan's patriarchal power structure continues to prevent sexual violence from being treated with sufficient gravity. In a patriarchal society that binds women to their roles as wives and mothers, a married woman is considered her husband's possession; any forced sexual relations thus tend to be tied to notions of obligation and wifely duty (Tsunoda 1995). Japan's existing domestic violence law represents an attempt to balance the husband-wife relationship; however, the psychological, sexual, social and financial control that husbands can have over their wives is still often overlooked in domestic abuse cases (Kaino 2010). Burns (2005) argues that Japanese law continues to frame rape as "an injury against the property rights of husbands or fathers and, thus, the patriarchal order", thereby contending that the rape law's true intention is the protection of chastity rather than women's human rights (69). Japanese feminists continue to fight against such traditional gender notions faced by rape victims in the criminal justice system (AJWRC 2008).

These three dynamics are embedded within and reinforced by institutional structures and cultural practices that are built around male power and privilege. They ensure that silence continues to surround rape as an issue within social and political discourse, acting as a suffocating barrier to keep victims of sexual violence from speaking out. Masayo Niwa (2004) points to the Super Free scandal of 2003 as evidence for how "[Japanese] society continues to exert tremendous pressure on victims of sexual violence to remain silent" (1). Members of an all-male student group called 'Super Free'2 used events to scout potential rape victims: once their victims were drunk and unable to resist, they were lured away then raped by club members, and photos were taken to stop victims from speaking out. With the fear of blackmail, only three out of the hundreds of suspected victims stepped forward to report the crimes committed against them.

But media coverage of the Super Free incident shows that it is possible to break through this culture of silence: the public discourse it generated prompted twelve more women to come forward following the arrests (Cybriwsky 2011). The success of the feminist movement in challenging dominant social norms of silence around domestic violence is further evidence of how 'taboo' subjects can change through public exposure. After a decade of advocacy and political mobilisation, Japanese women's groups successfully lobbied the government to introduce a law against domestic violence in 2001. Their achievement encouraged survivors to share their own experiences so that the law could be revised to include common-law couples and ex-spouses, showing that grassroots women's movements can bring about policy change in Japan (Shin 2011).

However, despite progress in the legal sphere, fictional representations of rape and sexual violence continue to inundate Japanese popular culture. This is

2 Super Free was a student group that promoted rave events in Tokyo nightclubs and was initially based in Waseda University. Its popularity saw the group expand to include students from other prestigious Tokyo universities, becoming an inter-university club with 30 members.

Hei-Lei Cheng New Voices in Japanese Studies, Vol. 8, 2016, pp. 77-97 
not a condition unique to Japan, as such scenes have become a normalised narrative device across numerous entertainment industries (Smith 2004; Heller-Nicholas 2011). For example, within the Japanese film industry, sexual violence is popular in the softcore pornographic 'pinku eiga' (ピンク映画; lit., 'pink films') genre, which emerged in the 1960s. As Jack Hunter (1998) argues, these films have a formulaic style where the "women ... fall in love with their rapists, and end up begging for more", leaving an impression that these films condone rape (81). Since the 1980s, these rape scenes have been "slowly phased out" of pink films due to cultural awareness and attempts to draw a female audience (Arnold 2015, 36). With other subgenres of pornography, however, the rape of young women remains a mainstay of the industry (Arnold 2015). Further, with the internet now allowing greater access to pornography, the diffusion and consumption of graphic imagery of sexual violence has dramatically increased over the past two decades (Omori et al. 2011). In many of these representations, women are depicted as "sexually materialised object[s] ready to be exploited (like a disposable toy) exclusively as a means to produce sexual gratification" for a primarily male viewership (Shibata 2008, 2). Feminist media critics vociferously oppose representations of this nature; instead, they call for sensitive representations that can effectively counteract the problematic representations that dominate and influence perceptions about rape and rape victims.

\title{
The Transformative Potential of Cultural Representations
}

The theoretical foundation underlying this article is the idea that all knowledge is constructed. The acquisition of knowledge and our understanding of the world is a dynamic process, which is ever-changing as individuals interact with the world as it changes around them:

\begin{abstract}
Knowledge is socially constructed; knowledge and the knower are interdependent; and all knowledge and knowing are embedded within history, context, culture, language, experience, and understanding [...]. We continually interpret our experiences and interpret our interpretations. And, as such, what we create (e.g., knowledge) is fluid, continually evolving, shifting, broadening, and changing. Thus, there is no finality to our knowledge-our meanings, understandings, or realities. What we create, we create with each other.
\end{abstract}

(Anderson 2007, 8-9)

Our engagement with entertainment opens us to popular culture's ability to either reinforce our existing values and beliefs or to challenge and transform them. It is therefore important to understand the processes and dynamics that work to shape our perspectives on the world, the people in it, and ourselves.

Mass media, through which representations are disseminated across a wide audience, have emerged as crucial social institutions involved in shaping public consciousness. As cultural artefacts, films provide a window into the values, beliefs and attitudes entrenched within a nation's cultural and social history. Stuart Hall (1980) argues that all messages have a dominant or preferred 
meaning encoded into them, and that these often reflect dominant ideological discourses. Thus, the constant repetition of certain messages and imagery in mass media serves to normalise and reinforce behaviours and ideas. So when rape narratives are used in popular culture, they can "reinforce certain social patterns and trends and invalidate others" (Durham 2008, 148).

However, within mass media there are always competing voices and alternative perspectives that resist hegemonic ideologies. As media production and consumption increases, media representations have become sites where users can access alternative viewpoints that contribute to generating change (Halberstam 1993; Fuentes 2013). By constructing gendered stories of sexual violence from different perspectives, there is a denial of pleasure to the dominant version of the male heterosexual gaze (Fuentes 2013). Rape representations that resist conventional portrayals of rape have the potential to "destabilise the real" by reorienting our perceptions regarding rape and rape victims (Halberstam 1993, 199). From this potential to transform the collective imagination emerges the potential to induce change.

\section{Women Engaging with Rape Representations}

Key to this article's direction is Sarah Projansky's book Watching Rape (2001), which explores rape representations within American film and television since the 1980s. Projansky argues that feminists are faced with a conundrum born of "a desire to 'end' rape and a need to 'represent' (and therefore perpetuate discursive) rape in order to challenge it" (19). That is, rape depictions can initiate discourse but still inevitably "contribute to the existence of violence against women in media culture" $(2001,96)$. The argument put forward in this paper is also caught in this dilemma: for cinema to serve as a potential site for activism against rape, the female body must first be victimised to generate activist discourse. Projansky recognises that rape representations can include feminist depictions of rape which "provide an opportunity for reading the representation of rape in ways that have the potential to empower characters and/or spectators rather than ... to increase their experience of vulnerability" $(2001,61)$. While she focuses more on aspects that "seek to recuperate or undermine that empowerment" (2001, 61), I concentrate on the opposite. That is, I argue that although these disempowering elements do exist, nuanced representations of rape can encourage critical discussion about sexual violence within the general public.

This article is also guided by a question raised by Eva Maria Koopman's (2010) research on the ethics of representing and reading rape in literature. Koopman (2010) argues that "representations of seemingly individual suffering and violence can bring to the fore disturbing ethical issues and thus need to be read in an openness to being ethically unsettled" (11). The issue she poses is, "under which conditions, if at all, [is] representing the suffering of others ... possible and desirable" $(2010,13)$ ? Koopman argues that "depicting an immoral act is not in itself immoral, it is the way that the immoral act is represented that matters" $(2010,110)$, a point that will be threaded throughout this article. 
For feminists on the production side of popular culture media, the issue of how to depict sexual violence in a manner that does not (re)traumatise their audience is a constant question. With any fictional work, the intended response is not always elicited and so it can be difficult, if not impossible, to have a rape scene that does not trigger an uncomfortable visceral response in rape survivors, as well as in those who have not experienced rape (Chris 2013). Although this is not true of all survivors, there are some who recognise that sexual violence should not be exempt from artistic expression; it just needs to be represented with more sensitivity (Friedman 2014).

Increasingly, feminist media critics are using digital platforms such as social media and online forums to interrogate pervasive representations of rape within popular culture. Major criticisms include the excessive number of gratuitous rape depictions, their frequent use as devices to shock audiences, and minimal screen time given to exploring the impact of rape on victims as well as their long healing process (Goerke 2013; Friedman 2014; Rodriguez 2014; Myrick 2014; Phillips 2016). It is also important that some of these voices are also the voices of victims asserting their dissatisfaction. Feminist backlash towards violent sexual imagery demonstrates how the encoding/decoding of message "may not be perfectly symmetrical" (Hall 1980, 54). That is, although media makers intend for a specific idea to be received, audiences are not passive consumers of media messages and can respond differently depending on their degree of identification with the maker's point of view. Using the internet to express their opinions and facilitate dialogue on sexual violence, feminist voices in the digital sphere continue to expand their influence and are becoming a voice that the entertainment industry cannot ignore.

\section{BEARING WITNESS: THE RAPE SCENE AND THE VIEWER}

While most people shy away from viewing violence in real life, audiences willingly expose themselves to acts of factual and fictional violence in the consumption of news and popular culture. As representations of immoral and illegal acts, rape scenes in popular fiction films raise a range of ethical issues. When presented with a cinematic rape sequence, the viewer is invited to partake in a spectacle of pain and suffering, both physical and mental. As viewers of these representations, they take on the role of witness and are presented with an ethical dilemma: how can one be entertained and take pleasure from viewing images of suffering?

First, an awareness of fictionality allows the viewer to distance themselves from their involvement in viewing violent acts (Aaron 2007). Furthermore, the viewer can seek to justify being entertained by these acts when they are then shown to be condemned or punished, placing both film and viewer in moral, social and legal alignment (2007). Although the viewer may choose to avoid or ignore this ethical quandary, as Michele Aaron (2007) argues, the imagined suffering of others is "something [the audience is] always implicated in, not only as consumers but as consensual parties in the generation of characters' suffering for our entertainment" (112). This 
involvement, along with the desensitising effect of continual exposure to violent imagery, ${ }^{3}$ produces a state of indifference to images of suffering. The question thus turns towards the conditions that can provoke viewers into becoming active spectators critically and ethically engaging with the text and the subject of rape.

\section{An Unsettling View: Closing the Distance between Screen and Spectator}

Hidden within the processes of production and consumption is a complex, dynamic array of interactions between spectator and a cinematic text. By viewing representations on the screen, the viewer becomes a willing participant to engaging with the text and its producers, creating an implicit contract between spectator and spectacle (Aaron 2007). The viewer's agreement to this unspoken contract becomes unstable as the subject matter begins to challenge social sensibilities. Being entertained by watching depictions of violent acts can possibly place the spectator in an uncomfortable position of moral reflection. With rape representations, the sexual element adds to the dilemma of being a spectator to depictions of violence. As Tanya Horeck (2004) asks in her analysis of rape and spectatorship, "Are we bearing witness to a terrible crime or are we participating in shameful voyeuristic activity?" (vi). As a witness, the spectator is allowed some measure of innocence in their position as bystander; in contrast, the voyeur spies from a distance, potentially gaining sexual pleasure from their watching (Wilson 2012).

Voyeuristic pleasure gained from fictional scenes of violence is grounded in the knowledge of being a safe distance away from the represented experience of suffering. In the case of sexual violence, the potential for the voyeur to experience sexual pleasure is increased. Cinema's fascination with the human form lets the male spectator gaze upon and gain sexual pleasure from the female body: women, put on display for the enjoyment of men, are a spectacle objectified through the male gaze (Mulvey 1989). Female bodies thus become "sites for invasion, penetration, and are often presented in a voyeuristic manner" (Viteo 2012, 15). Within this context, privileging the rapist's point of view could potentially steer the spectator toward identifying with the rapist's perspective. Koopman (2010) argues that this can produce a voyeuristic desire to "see [more], wanting to indulge in the sexual violence from the safe position of the spectator" (18). While voyeuristic pleasure is a socially undesirable affective response to rape representation, this may induce ethical self-reflection if the spectator then becomes ashamed of their initial reaction. If guided to consider that their "internal feeling about a scene [is] abnormal", the spectator's shame can outweigh their sense of pleasure, leading them to focus on more socially acceptable emotions and a contemplation of their spectatorial role (Cartwright 2008). 
In The Ravine of Goodbye [さよなら渓谷; 2013], director Tatsushi Ōmori unsettles the viewer by drawing attention to their position as spectator of a sexual assault, contrasting the viewer's spectatorial position with that of another character in the room. Based on Shūichi Yoshida's 2008 novel of the same name, The Ravine of Goodbye is a story about the repercussions of a gang rape on the victim and one of the perpetrators. At the heart of the film is the relationship between a couple, Shunsuke and Kanako Ozaki, who are neighbours of a mother accused of murdering her child. When a reporter, Watanabe, investigates a tip that Shunsuke was having an affair with the accused, he discovers that Shunsuke was involved in the gang rape of a girl, Natsumi Mizutani, during his university years. Following many misfortunes, she has since disappeared. Eventually, it is revealed that Natsumi is in fact Kanako. Struggling to escape her past, Natsumi met Shunsuke after many years, and following a turbulent struggle with anger and guilt, the two reinvented themselves as husband and wife in a small town.

The film uses a flashback to show the gang rape that shadows Kanako and Shunsuke's relationship. Watanabe is investigating at the university when the scene dissolves to the past, where a young woman and three young men are talking next to a pile of empty beer cans in a clubhouse room. As the camera slowly tracks closer to the jovial group, a couple quietly talking is brought into the shot. When the young woman from the group excuses herself momentarily, the camera reorients to focus on the couple, Natsumi and the young man. The camera lingers on the two's quiet moment before the boisterous trio intrudes. After a moment of play fighting between the men, the camera cuts away from the group to the young woman returning into the clubroom doorway. From offscreen, a male voice rings out, telling the others "hold her down" (ちゃんと抑えて) (00:51:58). Seeing this, the young woman quietly slips away. The camera remains steady on the empty doorway after she leaves the scene, while Natsumi's screams of protest continuing to ring out. Surrounded by the four boys, only her legs can be seen as her shrieks cut across the rowdiness of the boys and the crescendo of the haunting background music.

Director Ōmori guides the viewer to focus on Natsumi's suffering and victimisation whilst trying to avoid evoking voyeuristic pleasures by presenting, unambiguously, the scene as a rape. By emphasising her nonconsent and the boys' use of force, he emphasises the violence and pain of rape rather than the sexual aspects. The viewer is manoeuvred to a crossroad where they can choose to end these images of suffering (by stopping or walking out of the film) or to endure them. The first choice ends the unspoken contract between the viewer and the text, as the viewer no longer consents to viewing the images being shown. The latter choice leads the spectator to the role of witness, a position where they might choose to confront the issue of deriving pleasure from images of suffering. Like the woman who left the scene, the viewer is a witness and bystander to this fictional rape; unlike the woman, who is able to leave and end her role as witness in the film, the viewer cannot do so if they choose to watch the film to its completion. For the viewer that chooses to continue watching, Ōmori creates an uncomfortable atmosphere by prolonging Natsumi's screams as the camera lingers on the empty doorway 
that they cannot leave through. As they watch her struggle, the viewer is invited to reflect on the victimisation and suffering being played out before them.

However, there are limitations to the extent to which the spectator can empathetically understand the traumatised other: being only witnesses to fictionalised representations of sexual violence, spectators cannot truly understand the experience of suffering. Referring to war photography, Susan Sontag (2003) writes that those "who have never experienced anything like what [people affected by war] went through don't understand ... we truly can't imagine what it was like" (126). Empathy, with respect for the experience of those that have suffered, is a desirable response. Yet, the exact experience of another's suffering cannot truly be understood.

A cinematic rape sequence involves considerations from both the producers and the consumers of these representations. For filmmakers, what and how to represent can heavily influence the viewer's response to a rape scene. Uncompromising depictions of sexual violence can guide the viewer to an unsettling ethical position where the victim's suffering becomes etched in their minds and their awareness of their own role as witness is heightened. By closing the distance between the viewer and images of suffering, the filmmaker can trigger self-reflective spectatorship. But while they can attempt to manoeuvre the viewer away from socially undesirable reactions through their directional choices, it is ultimately up to the individual viewer to transition from ethical reflection to social action.

\section{EXPOSING THE SILENCE: THE VICTIM AND EVERYONE ELSE}

In a media-rich environment, cultural representations of the everyday are an oft-inescapable thread woven into the fabric of daily life. Shaped by the society and culture in which they are reproduced, representations are constructions of reality (Hall 1997). As such, fictional films can serve as carefully crafted windows through which the audience is directed to view and become involved in specific experiences, and are a useful avenue for filmmakers to communicate certain messages. By embedding a message within the cinematic narrative, filmmakers can use these spaces for overt or subtle social commentary while still providing entertainment to viewers.

\section{Exploring Representations of Secondary Victimisation}

From first responders to providers of recovery services, there are various avenues for victims of sexual violence to turn to for assistance. Victims are not always able to find help from these agencies, however, and may even be subjected to further victimisation and trauma. This is known as 'secondary victimisation' (Campbell 2005). In DV: Domestic Violence [DV : ドメステイック・ バイオレンス; 2005], director Shun Nakahara draws attention to the poor support services in place for domestic violence victims. DV: Domestic Violence is 
about the increasingly violent marriage between two characters, Shōgo and Yasuko. The marriage begins its downward spiral when Yasuko does not keep her promise to quit her job and become a housewife. The escalation of physical, psychological and sexual abuse that follows results in Yasuko seeking a way out of the situation.

DV: Domestic Violence presents two rape scenes as part of the escalation of violence in Shōgo and Yasuko's marriage. The first occurs after Shōgo sets up a schedule of tasks, including arranging nights for sex. One night when Yasuko is sick, Shōgo insists on following the calendar and having sex regardless (00:25:35). Coughing throughout the ordeal, the camera repeatedly focuses on Yasuko's pained face as she continues to tell him to stop (ちょっ…やめて) (00:25:51) and that it hurts (痛い) (00:26:35). The second rape scene occurs after Yasuko has been forced to quit her job and has endured weeks of abuse. In this scene, Yasuko's non-consent is not voiced but demonstrated through her body language. When Shōgo tells Yasuko to be vocally expressive (声出 せ、声出せ), she remains silent (00:37:52). Yasuko is lifeless as Shōgo lifts up her limbs and her body for leverage. She is completely unresponsive, both physically and vocally. The timeline is unclear but this is likely another of Shōgo's scheduled sessions. Her lack of response and resistance indicates that this is one of many unwanted sexual incidents within the marriage.

The film also represents Yasuko's struggles with various institutions, and the viewer is positioned to contemplate the realities faced by victims trying to seek help, as well as the role that society plays in a rape victim's recovery. Nakahara was motivated to make the film following Japan's introduction of domestic violence laws in 2001. He recognised that "regardless of how well-intended the law is, if people do not properly enforce it then the law means nothing" (どん なに立派な法律でも、それを運用する人たちがしっかりしてくれなければ、何の意 味もありません), and made the scenes between Yasuko and support providers, discussed below, as “a message to people working in public institutions" (公 的機関に携わる人たちへのメッセージ) (Iijima 2012). This sentiment is clearly conveyed in the film.

Yasuko's interaction with law enforcement in the film is a good example of how cinema can serve as a space for social commentary. Following a beating by her husband, Yasuko escapes to a police station for assistance. In the conversation between Yasuko and the policeman, the viewer is shown how the domestic violence law as it was intended is not necessarily applied in reality. The policeman is sympathetic but reluctant to intervene in the situation:

Policeman: Well, the police can't really get involved in domestic matter like this. A family matter really ought to be solved at home.

Yasuko: What about the domestic violence law? ${ }^{4}$

(00:50:50)

As it becomes clear that the officer considers that personal matters within marriage are too 'minor' for the criminal justice system, the officer then 
presses Yasuko further, asking how often her husband has beaten her. After responding that it has been a daily occurrence over the past three months, the officer asks her why this has occurred.

P: There has to be a reason for him to beat you.

Y: The reasons are extremely trivial matters.

P: It may just be you that thinks that. ${ }^{5}$

$(00: 51: 28)$

The policeman's prodding stuns Yasuko. When Yasuko asks him for clarification, he asks if her husband has used any weapons against her. She replies yes, to which he then asks, “Are you sure?" (本当に?) with a questioning tone (00:51:52). At this point the camera switches from the stationary shot of the two conversing to close-up shots of their faces instead. When the camera is on Yasuko, the discomfort and unease that is afflicting her is clear. Yasuko is hunched with her head bowed down and does not make eye contact with the officer (00:51:55). The tight framing of the close-up shot emphasises Yasuko's feelings of being trapped by her inability to make the officer understand and the self-doubt brought about by the questioning.

The policeman recommends Yasuko to visit a consultation centre because domestic violence can become very serious, and begins to explain the consequences for her husband if the court grants her appeal for protection. As he does so, the camera switches to Yasuko, now with a blurry figure appearing in the background. As the officer expounds about how her poor husband would be kicked out of his home and get a criminal record, the encroaching figure suggests a looming threat as it approaches the station. Gradually, it becomes clear that the figure is Shōgo and the scene begins to take on a horror-like dimension, with a 'monster' bearing down on the female protagonist.

The ineptitude of the police officer is driven home by his juxtaposition with Yasuko after Shōgo arrives. The officer's grin when he greets Shōgo feels inappropriate for the viewer, who has seen the extent of the violence that Shoggo has inflicted upon Yasuko. As the policeman's grinning face turns towards her, the camera follows his gaze and pans to the right, showing Yasuko's hunched figure with sounds of her muffled sobbing audible. The comparison of the two characters emphasises the emotional chasm between victim and institution. Although she found very little assistance, Yasuko's awareness of the sociolegal avenues available to her as a victim of domestic violence reflects the increased recognition of the issue. However, as the film shows, legal reform is merely a single stepping stone to effecting actual change within individuals, communities, and society.

The above analysis has focused on Yasuko as a victim of domestic violence rather than rape, as the film emphasises the physical aspects of domestic abuse over the psychological and sexual aspects. In the public discussion of domestic violence, physical violence tends to dominate the discourse (Pagelow 1988). Although the Japanese government recognises forced sexual activity as 
part of domestic violence, it is not referred to as 'rape' (Kakuchi 2003; AJWRC 2007). By letting physical violence dominate the discourse on spousal abuse in the Japanese legal framework, many victims fall between the cracks as physical violence is not a necessary condition for marital rape to occur (Russell 1982; Finkelhor and Yllo, 1985). Nakahara never explicitly establishes the sexual violence that Yasuko faces as 'rape' within the film. Although Yasuko indicates on a questionnaire that she feels sexual relations with her husband are not normal (夫との SEX は正常である?) (00:00:29), none of the characters call these incidents of unwanted sexual intercourse 'rape'. By not doing so, Nakahara allows the viewer to reach their own understanding of the nature of these acts. Whether the audience interprets these scenes as rape sequences, as I have, will be dependent on the individual viewer's perception on marital rape. The lack of acknowledgement of marital rape in the film reflects how the issue is treated within Japanese society and suggests how residual silence is built up around it, a problem that remains strongly rooted within many contemporary societies. Yet, while marital rape has been largely invisible in terms of public discourse, it has at least been drawn into the conversation through the broader problem of domestic violence.

As has been shown, the inclusion of social commentary within films makes cinema a possible site for communicating issues of social importance. Aside from picking up on deliberately included messages, the viewer can also garner unintended insights into the cultural, social and historical conditions under which the film has been created. Cinema can be a powerful tool for confronting viewers with the social and institutional prejudices faced by rape victimsexperiences that may otherwise be distant to them-and break the silence that keeps these struggles unheard. By focusing on these barriers throughout the cinematic narrative, the viewer is encouraged to reflect upon what they know and think about the realities and injustices of rape for victims.

\section{BECOMING A SURVIVOR: A GLANCE INTO A VICTIM'S PROCESS OF RECOVERY}

In this final section, I return to one of the common criticisms of rape representations: that the victim's recovery story is rarely given attention and the realities of rape trauma are not fully explored. Here, I examine how The Ravine of Goodbye provides one such story, by exploring Natsumi's journey to work through her trauma. By representing rape's lingering effects, the filmmaker portrays the long-term nature of rape recovery-an experience that the victim has been conditioned, through social and cultural norms, to keep secret and hidden from the rest of society. In The Ravine of Goodbye, the protagonist Natsumi is shown confronting her abuser-not an action usually taken by victims of abuse. Confronting the abuser, usually symbolically, is considered an important part of healing and this can be enough for some individuals to recover from abuse. For others, it is a major step in a longer process (Freshwater et al. 2002). In exploring this personal journey, Ōmori creates a stage for the viewer to witness the emotional hardships faced by victims of sexual violence. This allows space for a dialogue between the viewer 
and the film that may facilitate a questioning of the social conditions that have created these barriers for victims.

Natsumi's confrontation with Shunsuke is a reversal of the power dynamics between victim and victimiser. Following the rape, Natsumi is unable to escape from the stigma attached to rape victims. She tries moving on, going through a failed engagement, miscarriage, domestic violence, suicide attempts. By contrast, Shunsuke has a relatively easier life, but is wracked by guilt for his past actions and cannot let go. Years after the incident, during a dinner, one of the other rapists mentions to Shunsuke that he had seen Natsumi at the hospital. Soon after, Shunsuke visits Natsumi, who becomes hysterical upon seeing him. Haunted by his actions, Shunsuke persistently sends letters to Natsumi, which she leaves unopened. Following another suicide attempt, she finally opens a letter and calls him. Shunsuke finds Natsumi sitting in a payphone booth, clutching the letter. She reveals that, in his letters, Shunsuke declares he will do anything for her. She doubts him at first, then realises that his declaration is genuine. From this point, Natsumi begins to test the limits of what Shunsuke will do to atone.

As Natsumi moves from town to town she is followed closely by Shunsuke. Things come to head in the countryside as a fierce confrontation erupts when Shunsuke tries to lend Natsumi his jacket. As the wind rages against them, Natsumi explodes:

No matter what happens, I will never forgive you. If you'd be happier if I died, then I never want to die. If you think you'd be better off dead, then I refuse to let you die. Don't you dare try and get comfortable with this. ${ }^{6}$

$(01: 16: 42)$

The mise-en-scene in this confrontation reflects Natsumi's turbulent emotions. In her shots, the camera's low angle suggests she is bearing down on Shunsuke. The dark lighting and storm clouds in the background emphasise Natsumi's thunderous rage as she unleashes her diatribe onto the silent Shunsuke. The direction of the wind, blowing from Natsumi toward Shunsuke, reinforces the active-passive roles they hold in this outburst and foreshadows the power dynamics of their relationship in the future-Natsumi as the decision-maker and Shunsuke as the passive receiver of her authority.

Following the confrontation, Natsumi begins the process of regaining control over her life by 'becoming' Kanako. At an inn, Natsumi signs in as 'Kanako' in the guest registry. Later, Natsumi explains to Shunsuke:

That night ... the name of the girl that went home. The girl that went home that night was called Kanako. That night, I ... Kanako went home. ${ }^{7}$

(01:19:40)

In 'becoming' Kanako, Natsumi allows herself a momentary escape from being a rape victim. This can be seen as a manifestation of the way that 
traumatised people may create new personalities to "deceive themselves into thinking that their worst traumas happened to 'someone else,' not to them" (Waugaman 2010, 853).

At one point, Natsumi runs off after telling Shunsuke to stop following. After a while, she stops and looks back, finding him no longer behind her. Eventually, he returns and apologises again, to which Natsumi reveals that, upon his absence, she wanted him to return. Upon hearing this, he breaks into uncontrolled sobbing, and the two come to a quiet understanding. Soon after, Shunsuke tells Natsumi that his finances are low and she must decide what happens after this. Renting a small apartment with the remaining money, they begin anew by reinventing themselves as husband and wife.

Peppered throughout the film, from small decisions like buying kitchen cabinets to more crucial ones like the possibility of sending Shunsuke to gaol, Natsumi is given control of the relationship. The most striking way this manifests is through Natsumi's sexual empowerment. Constance Mui (2005) argues that traumatic violence, such as rape, severs the body's unity with the self. For a person to "feel at home in the world, one must first feel at home with one's body" $(2005,160)$. Rape disrupts this oneness by making the victim painfully aware of the body that has betrayed her (2005). To overcome this betrayal, victims often choose to desexualise themselves in order to "regain control of [their] own body boundaries" $(2005,159)$. In their study of the effects of rape on sexual activity, Ann Burgess and Lynda Holmstrom (1979) found that most rape victims do resume sexual activity over time, with one interviewee saying that having sex on her own terms was "like I was saying to myself, 'I'll have an upper hand now"' (652).

In The Ravine of Goodbye, Natsumi's resumption of sexual activity symbolises reclaiming control over her vulnerable body and sense of self. The film begins by showing Kanako and Shunsuke's sexually active relationship, in a sex scene that dominates the first eight minutes. The first time the two engage in sex since the rape is also the last sex scene in the film, appearing as a flashback to the past. At first, Natsumi pushes Shunsuke away, stopping any further advances. When she does eventually allow his advances, Natsumi is both consenting to Shunsuke and also reclaiming control over her own desires. In other scenes, Natsumi is shown as the instigator, and in control of what is permissible. By choosing to become sexually active with the partner of her choice, Natsumi takes back what the rape forcibly took away from her: the control over her body and the choice to act upon her sexual desires.

While acknowledging some of the sensitive, thoughtful elements of the narrative, it is also important to critique the problematic aspects too. For example, Natsumi and Shunsuke's new life as a married couple falls into the previously mentioned cliché of the victim falling in love with her rapist, which provides an unlikely resolution to what is hardly ever resolved in this way, while also reproducing the general apathy towards the normalisation of sexual violence within popular culture. Also, the film presents an isolated story by focusing on Natsumi's individual struggle rather than exploring the 
structural causes that hinder her recovery. There are hints to systemic factors, but these are not the focus of the narrative. Furthermore, the film exemplifies the absence of female directors and screenwriters engaging with the subject of rape in the film industry, as well as the dearth of women working in production. This is not to assume that male filmmakers are unable to deliver responsible representations, nor that representations from female filmmakers are always sensitively done. However, women writing, editing or directing can potentially offer different perspectives and ways of representing women and sexual violence in a male-dominated industry (Mayne 1981; Dowd 2015; Michalik 2015). When writing a female character's struggle with rape, female writers and directors can possibly help to mitigate the mishandling of the subject through nuanced, thoughtful representations that respect the complexities and sensitivities around sexual violence.

Trauma narratives in cinema can provide a space for viewers to consider the painful experiences of working through trauma. By drawing the viewer into these stories, the filmmaker can show the resilience and determination that survivors of gendered violence experience as they work through their pain, as well as break through internalised silences around this issue. Faced with these uncomfortable narratives, the viewer is presented with an opportunity to reflect upon the nature of trauma from sexual abuse and the way that survivors overcome these wounds in silence. Making the story about the victim alone is unlikely to end the problem of sexual violence in society, but a focus on victims' perspectives at least fulfils the demand from feminist critics for stories that do not cast aside the victims.

\section{CONCLUSION}

Cinema is both a source of entertainment and an avenue through which knowledge is developed and disseminated. As such, it is important to cultivate a keen awareness of the influence that fictional representations have in the process of knowledge formation, and how they shape our imaginations and ways of seeing the world. Aware of the mechanisms at play between filmmaker and viewer through the text, an active viewer is able to critically engage with and realise this discursive potential inherent within the cinematic space. Examining the cinematographic style and narrative content used by filmmakers in The Ravine of Goodbye and DV: Domestic Violence, I have argued that representations of rape and rape recovery have the potential to inspire ethical reflection by the viewer regarding rape and rape victims.

The subject of rape representations in popular culture will continue to be a contentious issue in media criticism. Yet, these representations can raise awareness, challenge dominant perceptions and stimulate public discussion. Feminist critics face a difficult conundrum where they fight to end rape in society while having to tolerate representation of sexual violence to generate discourse. My goal is to provide readings that show how rape representations can potentially empower victims and, in turn, the viewer. It is also 
important to recognise that films can perpetuate ideologies that undermine this, creating a paradox. This does not negate the discursive potential in film for bringing about change, but it is essential to call attention to the ways that even well-intended films can reinforce sexist and anti-feminist discourse.

Rape representations have the discursive potential to break the silence which surrounds sexual violence. By avoiding eroticised depictions of rape and emphasising the violent nature of the act, the filmmaker makes it tougher for the viewer to not reflect upon the fact of sexual violence. The contextualisation of a rape scene within a narrative is also significant: depicting shattered lives within social and cultural conditions encourages the viewer to engage in a social critique of dominant attitudes towards rape and sexual violence. By including the victim's recovery, the viewer is shown the traumatic impacts of rape and the long, ongoing process of healing. Ideally, these fictional depictions of rape can further personal introspection, raise public awareness, stimulate dialogue about sexual violence and encourage further participation in activism against sexual violence.

In my analysis of the two chosen films, I have primarily focused on how the filmmaker can elicit reflective responses within the viewer through the cinematic space. There is a need for filmmakers to be aware of the complexities in representing rape. As well, the viewer has a responsibility to decide whether to critically engage with cinematic representations of rape and reflect upon how they feel about the issue. The discussion of fictional depictions in popular culture alone is unlikely to end the silence that continues to keep the actual experiences of both victims and survivors hidden. However, alongside the efforts of Japanese feminists who are breaking the silence and working to change attitudes to sexual violence in Japanese social and legal spheres, I hope to challenge the dominant discourses surrounding sexual violence.

\section{REFERENCES}

Aaron, M. 2007. Spectatorship: The Power of Looking On. London: Wallflower Press.

AJWRC (Asia-Japan Women's Resource Center). 2007. "Executive Summary of 'Violation of Women's Rights in Japan': Alternative Report to the UN Committee Against Torture $38^{\text {th }}$ Session". Voices from Japan 19, 5-10. Accessed 6 February, 2016. http://www.ajwrc.org/english/sub/voice/19-1-2.pdf.

AJWRC (Asia-Japan Women's Resource Center). 2008. "Sexual Violence in Japan: Challenging the Criminal Justice System”. Voices from Japan 21, 14-16. Accessed 20 May, 2016. http://www.ajwrc.org/english/sub/voice/21-1-3.pdf.

Anderson, H. 2007. "A Postmodern Umbrella: Language and Knowledge as Relational and Generative, and Inherently Transforming". In Collaborative Therapy: Relationships and Conversations That Make a Difference, edited by H. Anderson and D. Gehart, 7-19. New York: Routledge.

Arnold, M. 2015. "Sex Every Afternoon: Pink Film and the Body of Pornographic Cinema in Japan". PhD dissertation, University of Michigan. 
Asatori, S. and F. Suzuki. 2009. "Discrimination in the Field of Reproductive and Sexual Rights in Japan". Paper presented at The Convention on the Elimination of All Forms of Discrimination Against Women 44th Session, July 20-August 7.

Buckley, S. 1997. Broken Silence: Voices of Japanese Feminism. Oakland: University of California Press.

Burgess, A. and L. Holmstrom. 1979. "Rape: Sexual Disruption and Recovery". American Journal of Orthopsychiatry 49: 648-57. http://dx.doi.org/10.1111/ j.1939-0025.1979.tb02650.x

Burns, C. 2005. Sexual Violence and the Law in Japan. New York: Routledge.

Campbell, R. 2005. "What Really Happened? A Validation Study of Rape Survivors' Help-Seeking Experiences With the Legal and Medical Systems”. Violence and Victims 20 (1): 55-68. http://dx.doi.org/10.1891/0886-6708.2005.20.1.55

Cartwright, L. 2008. Moral Spectatorship: Technologies of Voice and Affect in Postwar Representations of the Child. Durham: Duke University Press.

Chris, C. 2013. "Queasy Questions About Media Effects". Contexts 12 (3): 60-2. http://dx.doi.org/10.1177/1536504213499881

Cybriwsky, R. 2011. Historical Dictionary of Tokyo. 2nd edition. Lanham: Scarecrow Press.

Dowd, M. 2015. “The Women of Hollywood Speak Out”. New York Times, November 20. Accessed 12 January, 2016. http://www.nytimes.com/2015/11/22/ magazine/the-women-of-hollywood-speak-out.html?_r=0.

Durham, M. 2008. The Lolita Effect. New York: The Overlook Press.

DV: Domestic Violence [DV:ドメスティック・バイオレンス]. 2004. Directed by S. Nakahara [中原 俊]. DVD. Tokyo: Happinet Pictures.

Finkelhor, D. and K. Yllo. 1985. License to Rape: Sexual Abuse of Wives. New York: Holt, Rinehart, \& Winston.

Freshwater, K., C. Ainscough and K. Toon. 2002. "Confronting Abusers: The Opinions of Clinicians and Survivors". Journal of Child Sexual Abuse 11 (4): 35-52. http://dx.doi.org/10.1300/J070v11n04_03

Friedman, J. 2014. Rape on TV-More Than Just a Plot Twist. Accessed 17 July, 2014. http://prospect.org/article/rape-tv\%E2\%80\%94more-just-plot-twist.

Fuentes, M. 2013. "Nonkilling Media from a Gender Perspective". In Nonkilling Media, edited by J. Pim, 173-90. Honolulu and Omaha: Center for Global Nonkilling.

Gender Equality Bureau Cabinet Office [内閣府男女共同参画局]. 2014. “Josei ni taisuru bōryoku' ni kansuru chōsa kenkyū” [男女間における暴力に関する 調査]. Accessed 20 May, 2016. http://www.gender.go.jp/policy/no_violence/ e-vaw/chousa/h26_boryoku_cyousa.html. 
Goerke, C. 2013. Using Rape as a Plot Device. Accessed 17 July, 2014. http://www. feminisms.org/5844/using-rape-as-a-plot-device/.

Halberstam, J. 1993. “Imagined Violence/Queer Violence: Representation, Rage and Resistance”. Social Text 37: 187-201. http://dx.doi.org/10.2307/466268

Hall, S. 1980. "Encoding/Decoding". In Culture, Media, Language, edited by S. Hall, D. Hobson, A. Love and P. Willis, 128-38. London: Hutchinson.

1997. Representation: Cultural Representations and Signifying Practices. London: Sage.

Heller-Nicholas, A. 2011. Rape-revenge Films: A Critical Study. Jefferson: McFarland.

Higgins, L., and B. Silver, eds. 1991. Rape and Representation. New York: Columbia University Press.

Horeck, T. 2004. Public Rape. New York: Routledge.

Hunter, J. 1998. Eros in Hell: Sex, Blood and Madness in Japanese Cinema. London: Creation.

Kaino, T. [戒能 民江]. 2005. “Tokushū 1.4 DV hō seitei kara kaisei e: sono igi to kadai” [特集1.4 DV 法制定から改正へ—その意義と課題]. Kokusai Josei [国際女性] 19: $76-84$.

2010. "Domesutikku baiorensu bōshihō to josei ni taisuru bōryoku bōshi e no kadai” [ドメスティック・バイオレンス防止法と女性に対する暴力防止一の課 題]. Masse Osaka Kenkyū Kiyō [マッセ Osaka 研究紀要] 5: 15-24.

Kakuchi, S. 2003. "Japan's Battlers of Sex Abuse Confront Culture, Law". Women's Enews, April 17. Accessed 6 February, 2016. www.feminist.com/news/ news187.html.

Konishi, T. [小西 隆子]. 2009. Hanzai higaisha no kokoro no kizu [犯罪被害者の心の 傷]. Tokyo: Hakusuisha [白水社].

Koopman, E. 2010. "Reading Rape: Toward an Ethics of Responding to Literary Depictions of Suffering and Violence". Masters thesis, Utrecht University.

Linz, D., E. Donnerstein and S. Penrod. 1984. "The Effects of Multiple Exposures to Filmed Violence Against Women". Journal of Communication 34 (3): 130 47. http://dx.doi.org/10.1111/j.1460-2466.1984.tb02180.x

Mayne, J. 1981. "The Woman at the Keyhole: Women's Cinema and Feminist Criticism”. New German Critique 23:27-43. http://dx.doi.org/10.2307/487935

McLelland, M. 2005. Queer Japan from the Pacific War to the Internet Age. Lanham: Rowman \& Littlefield.

Michalik, Y. 2015. "Indonesian Women Filmmakers: Creating a New Female Identity?". Indonesia and the Malay World 43 (127): 378-96. http://dx.doi. org/10.1080/13639811.2015.1054139 
Mui, C. 2005. "A Feminist-Sartrean Approach to Understanding Rape Trauma". Sartre Studies International 11: 153-165. http://dx.doi.org/10.3167/1357155 05780282588

Mulvey, L. 1989. Visual and Other Pleasures. Indianapolis: Indiana University Press.

Myrick, T. 2014. "The Horror of Sexual Violence: The Representation of Rape in American Horror Story". Honours thesis, University of Utah.

Iijima, Y. [飯島 裕子]. 2012. “'Intabyū' Nakahara Shun-kantoku 'Kore ha DV? Sore tomo ai? Eiga no naka de sagashitemoraitai” [「インタビュー] 中原俊監督「れれ はDV? それとも愛? 映画の中で探してもらいたい]. The Big Issue Japan [ビッ グイシュー日本版]. Accessed 19 August, 2014. http://bigissue-online.jp/2012/ 10/09/interview/.

Niwa, M. 2004. "Why Violence is Directed towards Girls". Voices from Japan 12: 1-3. Accessed 14 October, 2014. http://www.ajwrc.org/english/sub/voice/12-1-1. pdf.

NPA (National Police Agency) [警察庁]. 2016. Hanzai tōkei shiryō [犯罪統計 資料]. Accessed February 1, 2016. http://www.e-stat.go.jp/SG1/estat/List.do ?bid $=000001066458 \&$ cycode $=0$.

Omori, K., Y. Zhang, M. Allen, H. Ota and M. Imamura. 2011. "Japanese College Students' Media Exposure to Sexually Explicit Materials, Perceptions of Women, and Sexually Permissive Attitudes". Journal of Intercultural Communication Research 40 (2): 93-110. http://dx.doi.org/10.1080/17475759 .2011 .581031

Pagelow, M. 1988. "Marital Rape". In Handbook of Family Violence, edited by V. van Hasselt, R. Morrison, A. Bellack, and M. Hersen, 207-30. New York: Plenum Press.

Phillips, J. 2016. "Confrontational Content, Gendered Gazes and the Ethics of Adaptation in Outlander and Game of Thrones". In Adoring Outlander: Essays on Fandom, Genre and the Female Audience, edited by V. Frankel, 162-81. Jefferson: McFarland.

Projansky, S. 2001. Watching Rape: Film and Television in Postfeminist Culture. New York: NYU Press.

Rodriguez, A. 2014. "Rape Culture, Trigger Warnings, and 'Bates Motel”'. Accessed 17 July, 2014. http://www.btchflcks.com/2014/02/rape-culture-trigger-warn ings-bates-motel.html.

Russell, D. 1982. Rape in Marriage. New York: Macmillan Press.

Shibata, T. 2008. "Pornography: Sexual Objectification and Sexual Violence in Japan and in the World". Working Paper, Centre for East and South-East Asian Studies, Lund University. Accessed 21 June, 2016. https://lup.lub.lu.se/ search/publication/3128514. 
Shin, K. 2011. “The Women's Movements”. In Routledge Handbook of Japanese Politics, edited by A. Gaunder, 175-86. New York: Routledge.

Smith, M. 2004. Encyclopedia of Rape. Westport: Greenwood Press.

Sontag, S. 2003. Regarding the Pain of Others. London: Penguin.

The Ravine of Goodbye [さよなら渓谷]. 2013. Directed by T. Ōmori [大森 立嗣]. DVD. Tokyo: Stardust Pictures.

Tsunoda, Y. 1995. "Japanese Women Confront Domestic Violence”. The Journal of the International Institute 3 (1): 7-17. Accessed 14 October, 2014. http://hdl. handle.net/2027/spo.4750978.0003.104

Viteo, K. 2012. "Day of the Woman?: Feminism \& Rape-Revenge Films". Masters thesis, University of Western Ontario.

Waugaman, R. 2010. "Samuel Clemens and Mark Twain: Pseudonym as Act of Reparation”. Psychoanalytic Review 97 (5): 835-856. http://dx.doi. org/10.1521/prev.2010.97.5.835

Wilson, L. 2012. "Physical Spectatorship: Noise and Rape in Irreversible". In Reverberations: The Philosophy, Aesthetics and Politics of Noise, edited by M. Goddard, B. Halligan and P. Hegarty, 121-32. London: Continuum.

Yatagawa, T. and M. Nakano. 2008. "Sexual Violence and the Japanese Criminal Judicial System”. Voices from Japan 12: 4-13. Accessed 14 October, 2014. http://www.ajwrc.org/english/sub/voice/21-1-2.pdf.

Zillman, D. and J. Bryant. 1984. "Effects of Massive Exposure to Pornography". In Pornography and Sexual Aggression, edited by N. Malamuth and E. Donnerstein, 115-41. Orlando: Academic Press. 


\section{The Angst of Youth in Post-Industrial Japan: A Narrative Self-Help Approach}
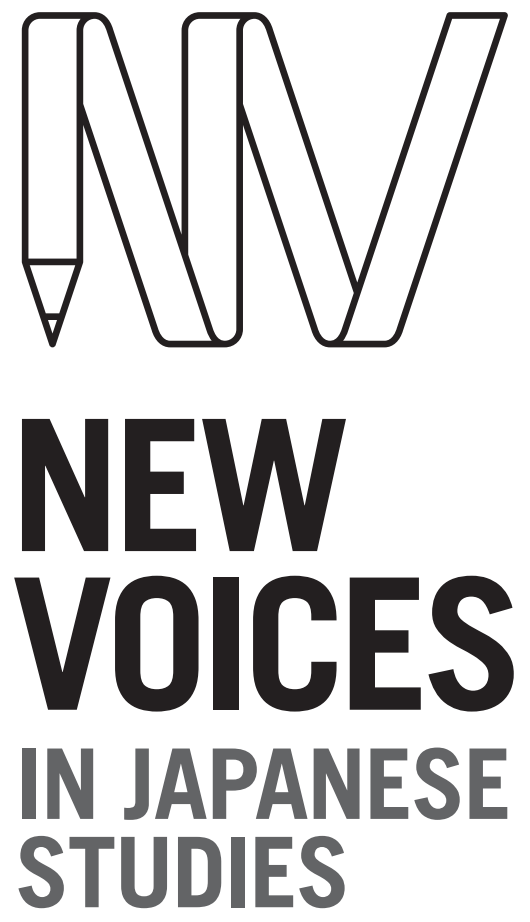

\section{RIE KIDO}

The University Of Adelaide

\section{ABSTRACT}

This paper explores the experience of angst (ikizurasa) among youth in longterm unemployment in post-industrial Japan, and proposes a model for supporting them. Currently, the dominant model for unemployment support consists of activation policies, which assume that users can identify their problems and clarify their needs in job seeking. However, for youth in situations of long-term unemployment, the effectiveness of these policies is limited. This paper argues that indirect support which focuses on (re)constructing human relationships through sharing narratives is a more effective way to help such youth mitigate their angst. In-depth interviews with two participants in a Self-Help Group for youth affected by long-term unemployment, as well as participant observations of the group, reveal how a narrative approach allowed participants to build new senses of self founded in realities shared by others. The analysis shows how these developments were crucial to helping the participants to find employment that suited their situations and needs.

\section{KEYWORDS}

angst; hikikomori; ikizurasa; isolation; labour force; narrative; post-industrial society; precarity; self-help; unemployment; youth

\section{JAPANFOUNDATION 8 \\ BRINGING JAPAN TO YOU \\ To link to this article: \\ http://dx.doi.org/10.21159/nvjs.08.05}

ISSN 2205-3166

New Voices in Japanese Studies is an interdisciplinary, peer-reviewed journal showcasing the work of emerging scholars from Australia and New Zealand with research interests in Japan.

All articles can be downloaded free at $\underline{\text { newvoices.org.au }}$

(c) The Japan Foundation, Sydney and Rie Kido, 2016

\section{(c) $(1)$}

This work is licensed under a Creative Commons Attribution-NonCommercialNoDerivatives 4.0 International License. 


\section{INTRODUCTION: IKIZURASA, OR INDEFINABLE ANGST AMONG YOUTH}

'Ikizurasa' (生きづらさ; lit., 'pain of living') is an expression that refers to a form of anxiety experienced by youth in post-industrial Japanese society, and is often associated with a sense of disconnectedness and self-blaming or suicidal tendencies (Tsukino 2007; Allison 2013). For example, Karin Amamiya, an activist and writer, regards herself as "always having had ikizurasa and suicidal tendencies” (ずっと生きづらく、自殺願望を持っていた) and states that this suicidal tendency was at its strongest when she held an insecure job (Amamiya 2007, 12). She explains:

\begin{abstract}
The jobs I did were dull jobs that could be done by anyone, and I fell into a vicious cycle where the more I was engaged in the monotonous work, the more worthless I felt [...]. Unstable job status intensifies an unstable mental condition, and the feeling of not being needed by society easily leads to a lack of self-worth. ${ }^{1}$
\end{abstract}

(Amamiya 2007, 12)

Ikizurasa refers to feelings of solitude, anxiety, low self-esteem, hopelessness and/or anger. Causes of ikizurasa are variously suggested to be unemployment, mental illness, family problems and/or being a school misfit. Amamiya holds that "many young people constantly experience a vague feeling of ikizurasa without knowing the reasons for it” (自分でも理由が分からずつねに漠然とし た生きづらさを抱えている人が多い) (Amamiya 2007, 13).

Amamiya and Kayano (2008) argue that this condition has two aspects: socioeconomic angst, and personal-mental angst (8-9). Socio-economic angst comes from degrading work conditions, lack of equality due to a widening socioeconomic gap (Satō 2000; Tachibanaki 2006) and the pressures of poverty (Yuasa 2008; Abe 2011), while personal-mental angst comes from a lack of self-worth and/or difficulty in relating to others. In reality, however, socioeconomic and personal-mental angst are intertwined in complex experiences, which makes it hard for people to narrate their experiences of ikizurasa in an understandable form. Yuasa and Nihei (2007) divide youth unemployment discourse in Japan in the 2000s into two categories: 1) “youth bashing” (若者 バッシング), in which youth were reproached for their lack of motivation; and 2) critiques which emphasised that youth are motivated but lack employment opportunities (330). Yuasa and Nihei argue that neither discourse can satisfactorily explain the feelings of youth who either "do not want to work" or who "want to work but can neither work nor move on" $(2007,330)$. This lack of an interpretive frame exacerbates the isolation of these youths and can generate a sense of ikizurasa. Yukiko Hijikata (2010) describes ikizurasa as a "nested agony" (入れ子式の苦しさ), which refers to "plural agonies, invisible in daily situations, ... hard to understand for both oneself and others, all of which amplify one’s difficulties” (複数の苦しさで構成され、日常では見えにくい部分が 存在しており……見えないために自他共に理解しがたく、そのことが、さらに苦し 
さを増大させている状態) (262). In short, the problem is that marginalisation from society due to lack of-or menial-employment in turn leads to a sense of alienation, in which victims find it difficult to understand their experiences or to share them with others. This article focuses on marginalised Japanese youth and explores: 1) how they experience ikizurasa in real life situations, and 2) how best to support them. In order to explore these issues, this article introduces a Self-Help Group in Osaka (hereafter, 'the SHG'), in which about ten to twenty marginalised youth meet once a month to discuss their feelings of angst. The SHG is run by a separate non-profit organisation (NPO) called 'Generative Garden'. The SHG is not funded by government because it does not align with government aims for youth support, which focus on finding jobs through career education, job matching and/or training (Tsutsui et al. 2014, 31). This allows the SHG to flexibly and practically respond to the ongoing daily problems of the participants.

I was involved in the establishment of the group in 2011, and have participated in the meetings as coordinator since then. This research project was developed through this experience and was informed by the action research cycle (Elliott 1991, 70; McNiff 2013, 56-61). Based on analysis of data collected through indepth interviews with participants and participant observation in the SHG, I will argue that: 1) young people who suffer from this kind of angst or ikizurasa have difficulty identifying their problems and the causes of their problems; and 2) underlying their angst is a deep sense of disconnectedness from others and from society. This article shows how, in the SHG, people became more capable of articulating their needs and constructing their sense of self by sharing their narratives with others. It further shows how that was made possible, not so much by directly attempting to fix participants' 'problems', but indirectly through allowing them to build new kinds of relationships with others based on a sharing of narratives. I suggest that the establishment of a new kind of relationality for them was the key to redressing participants' sense of angst, and that the SHG provided a social setting which made this possible. This article thus argues that the narrative approach (White and Epston 1990; Anderson and Goolishian 1992; Noguchi 2002) is significant in supporting marginalised youth who experience alienation in post-industrial societies, with people in Japan as a case in point.

\section{BACKGROUND TO YOUTH ANGST AND LIMITATIONS OF EXISTING SUPPORT FRAMEWORKS}

Ikizurasa which is exacerbated by economic pressure and often leads to alienation at work is a characteristic of post-industrial societies, where marginalisation of workers is common (Beck 1992; Furlong and Cartmel 2006; Berardi 2009; Standing 2011). For example, Franco 'Bifo' Berardi (2009) discusses "alienation of the soul", which can be understood as a similar phenomenon to ikizurasa (Allison 2013). He argues that in late capitalism, a "cognitariat", a compound of 'cognitive' and 'proletariat', emerges as a response to the advent of a newly flexible labour force. A key characteristic of the cognitariat, he continues, is that their cognitive dimensions, including 
desires, emotions and understandings of the meaning of life, have been affected by work conditions to such an extent that they have been influenced at the level of their "soul", with the consequence that their lives in their entirety become subject to relations determined by capital (Berardi 2009, 23). These alienating conditions aggravate states of panic or depression (Berardi 2009, 22-23).

Japan entered its post-industrial phase around 1994, when the service industry started to employ more people than the manufacturing industry (Oguma 2014, 17). In 1995, the Japan Business Federation (日本経営者団体連盟), ${ }^{2}$ an employers' organisation, published a report titled 'Japanese-style Management for a New Era' [新時代の日本的経営] ${ }^{3}$, advocating flexible employment practices which made it easier to place employees on casual or short-term fixed contracts, moving away from a more traditional model of permanent employment contracts in return for employees' company loyalty. This report proposed dividing Japanese employees into three categories: 1) core regular workers who develop firm-specific skills based on secure tenure; 2 ) highly skilled specialists employed for a short term but rewarded with high wages; and 3) low-skilled workers employed temporarily with low wages. Employers were encouraged to use these different types of employment (Japan Business Federation 1995). Around the same period, OECD (Organization for Economic Co-operation and Development) labour market statistics show a substantial increase in job insecurity among young people. The youth unemployment rate, which had been $4-5 \%$ during the 1980s and early 1990s-notably low compared with western countries-rose to around $10 \%$ in the 2000 s, reaching closer to the levels of Australia and the USA (see Chart 1). Correspondingly, the nonregular employment rate increased significantly among young people from

Chart 1: Youth Unemployment Rate, Ages 15-24 (OECD 2014)

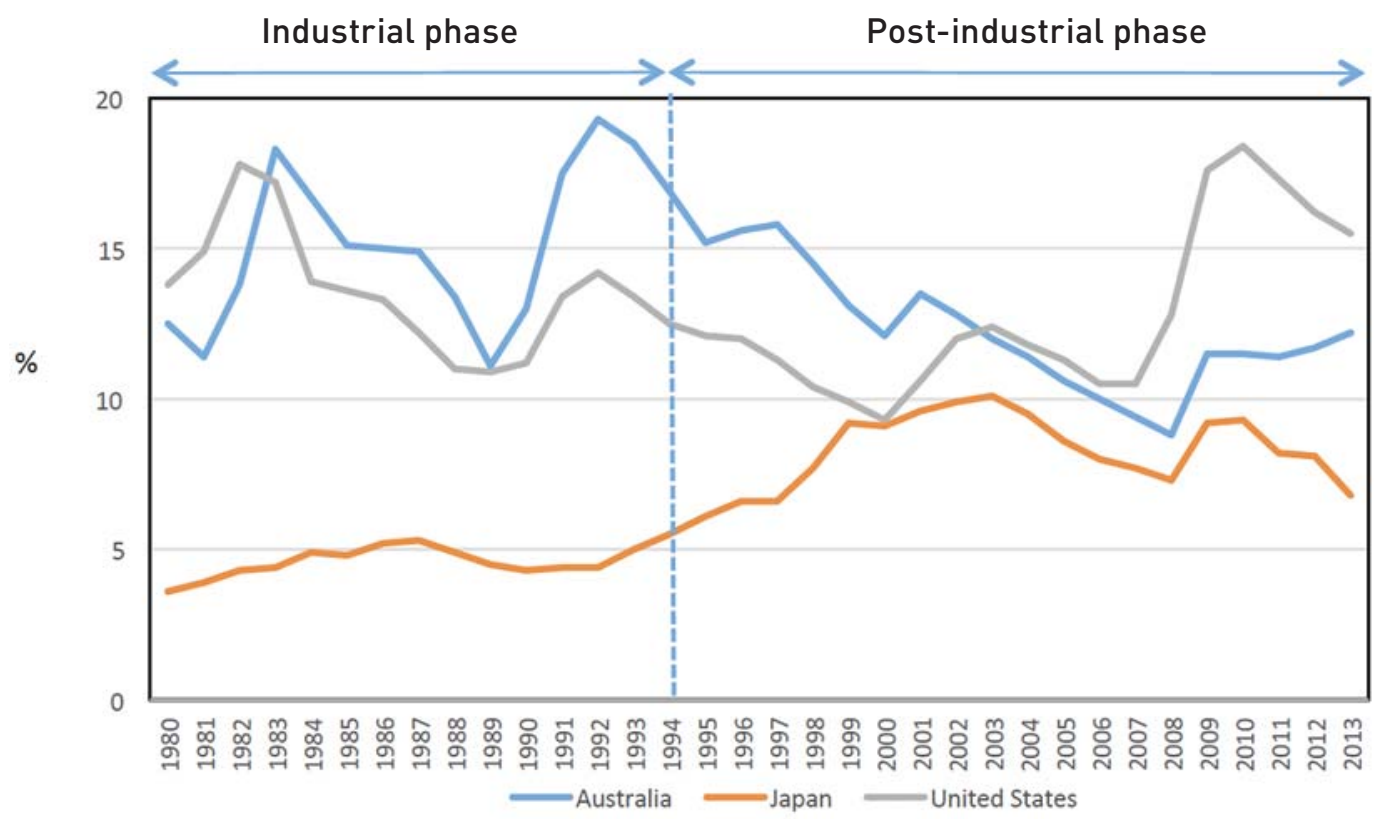

2 This organisation has since changed its name to the Japan Federation of Economic Organizations (経済団体

3 The English title of this report is the author's translation. The report is listed under the Japanese title in the 
the mid-1990s (Chart 2). In parallel, the word ikizurasa started to gain public recognition from the mid-1990s (Chart 3). According to the Cabinet Office, in $201254 \%$ of young people in their 20s felt that "they have experienced hardship in their social or daily life" (Cabinet Office 2012).

Chart 2: Non-Regular Employee Rate (Gender, Age), (MIAC 2014)

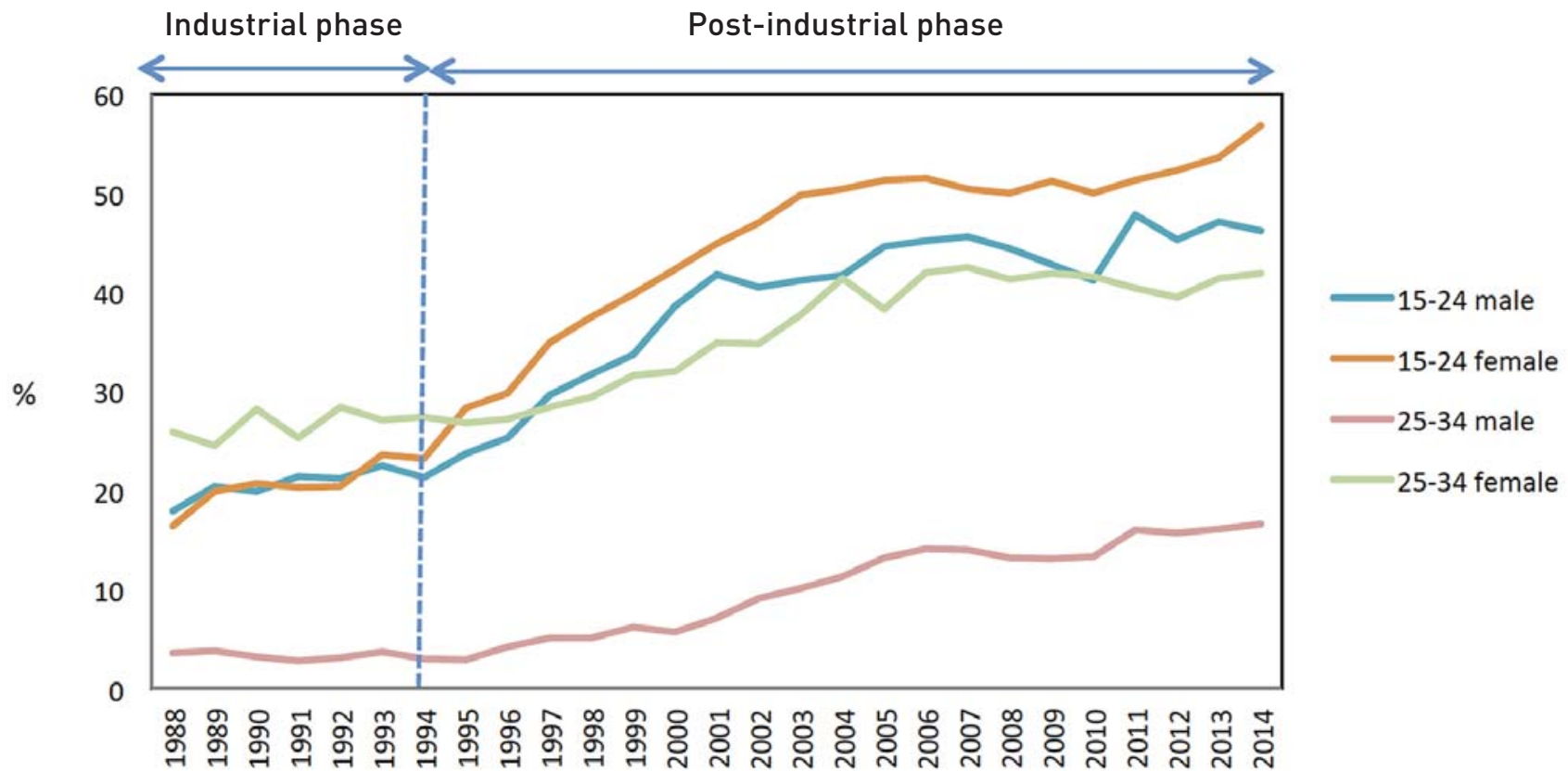

Chart 3: Total Number of Hits for 'Ikizurasa' by Keyword Search in Kikuzō 2 [聞蔵 II, Asahi Newspaper Article Search Engine] and the National Diet Library (NDL) Search

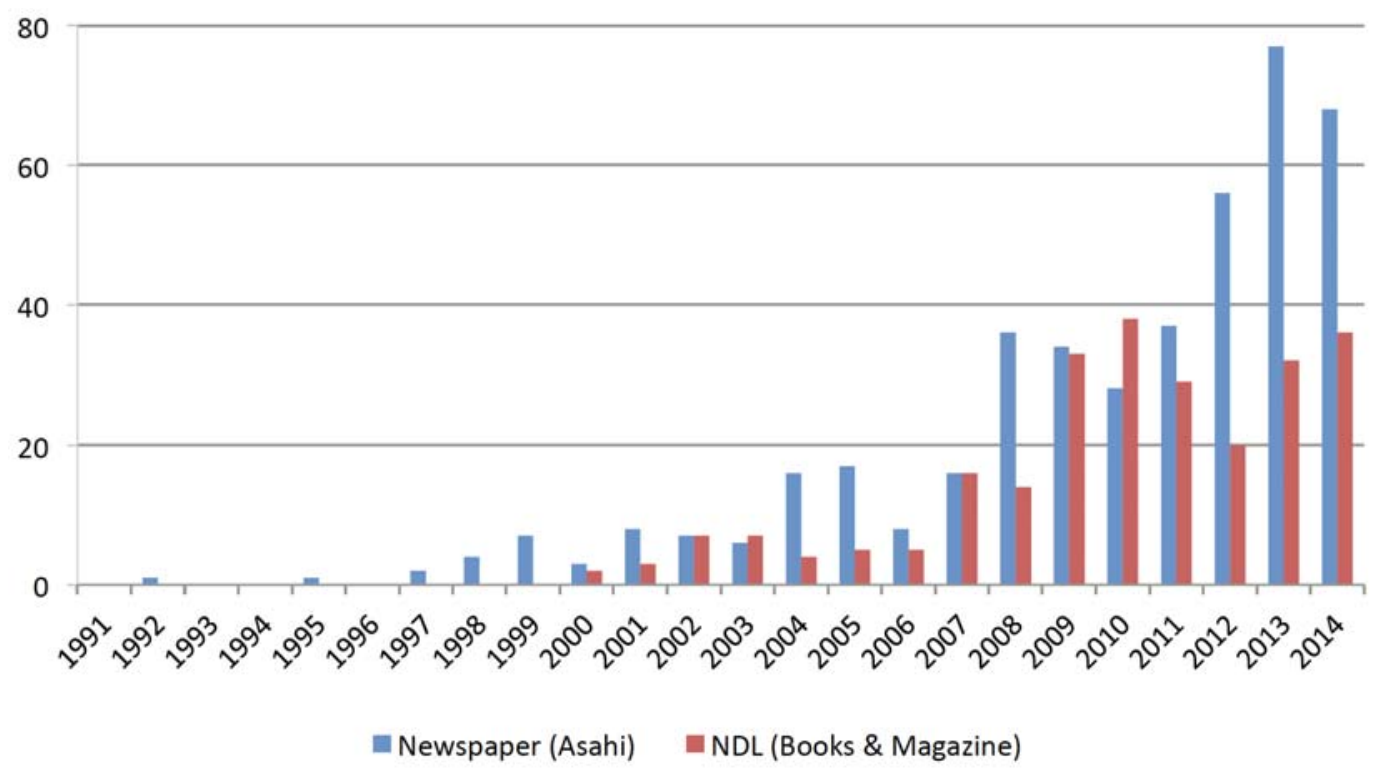

Since the early 2000s, the Japanese government has been adopting activation policies designed to bring "more people into the effective labour force, to counteract the potentially negative effects of unemployment and related benefits on work incentives" by stimulating individuals' motivation and attitudes towards employment (Duell et al. 2010; OECD 2013, 132). In 2003, 
the Plan of Challenge and Independence for Youth (若者自立挑戦プラン) was developed by a combination of the Ministry of Education, Culture, Sports, Science and Technology (MEXT), the Ministry of Health, Labour and Welfare (MHLW), the Ministry of Economy, Trade and Industry (METI) and the Cabinet Office. Based on this policy, a series of youth-related projects was developed, such as Job Cafe (ジョブカフェ), a community-based comprehensive employment support centre for youth, and the Japanese Dual System (日本型デ ユアルシステム), which offered combined programs of education at vocational schools and job skills training in organisations. In 2006, the Communitybased Youth Support Station (地域若者サポートステーション) was established as a base for youth support networks run by local governments.

Despite the investment in these initiatives, it is doubtful how effective activation frameworks can be in addressing youth anxieties, because activation policies primarily presuppose the participation of individuals who can clarify their own needs both to supporters and to themselves. Weil et al. (2005) have investigated activation policies in Europe and point out that, in the case of people whose sense of self is unstable because of prior hardships, putting pressure on them to work will have a limited effect since they often lack the social and psychological resources to make the necessary steps for a sustainable future. This can be seen in the following example:

Take Bob for example ... in and out of care homes, a mother that couldn't cope, a father he did not get on with, an unsuccessful school career, low self-esteem, and a life of emotional turmoil. [...] he had a problem engaging with 'life out there'-outside the project [i.e., job support]. In this situation, coaching Bob into the hard realities of labor market participation and the threatening loss of benefit would not give rise to any sustainable solution to the social exclusion that characterized his life.

(Weil et al. 2005, 143).

In Japan, too, it has been pointed out that there are unemployed people who have problems which cannot be resolved by job-support programs. Kei Kudō is the head of 'Raising-up Network' (育て上げネット), an NPO that aims to provide job support for youth. He argues that for unemployed youth to ask for support, it is necessary for them to first "recognise what to consult on" ( 相談したいことが明らかになっている), and to develop “trust in the person they consult with” (相談したい他者が信頼できる) (Kudō and Nishida 2014, 118). However, according to a survey by Kudō, more than $70 \%$ of unemployed youth who visited an employment support institution "[do] not even know how to manage unemployment” (無業である際に「どうしたらいいのか」すらわ からなかった), and this rate reached above $90 \%$ in the case of those who had been unemployed for more than three years (Kudō and Nishida 2014, 118-19). Considering the above issues, it is clear that support for unemployed youth, who experience angst and can neither clarify their needs nor trust others, should occur at a different level and employ a different approach. What, then, could be an approach, and at what level might it work best? 


\section{NARRATIVE APPROACHES}

In the following I explore the possibility of a narrative approach as a means for personal reinvention for marginalised youth, and to help them to cope with and redress the problem of angst. Weil et al. (2005) recognise that in these cases, "the capacity to construct and re-construct our identities and new narratives of self ... becomes an essential skill", and insist that "support for the development of such capacity [must] be made integral to notions of 'activation'” (8).

In light of this, I focus on a self-help practice which is based on a narrative approach. From a social constructionist perspective, a narrative approach understands that people interpret their experience as a narrated reality that is constructed through discursive interaction with others (White and Epston 1990; Anderson and Goolishian 1992). This narrative approach originated in family therapy, and has spread to many other fields including sociology, anthropology and management (Noguchi 2009). Existing clinical practices based on this approach include: 1) Narrative Therapy, 2) Self-Help Groups, 3) Open Dialogue, and 4) Tōjisha Kenkyū (当事者研究), or 'Self-Directed Study'.

Narrative Therapy is a method of family therapy where a problem is externalised by an individual and redefined as a "problem-saturated" narrative, which is gradually "re-authored" by the individual into a more positive and fulfilling story (White and Epston 1990, 16). This is achieved by communication between the client and the therapist, where the client is regarded as powerful enough to construct new voices and the therapist respectfully listens and engages with them, thus overcoming the traditional paternalism of a doctor-patient dyad (Anderson and Goolishian 1992).

Self-Help Groups are groups that facilitate mutual assistance among people who experience similar problems (Kubo 2004). Self-Help Groups are characterised by several features: 1) face-to-face interaction; 2) spontaneous organisation; 3) personal participation; 4) members' engagement in some action; 5) focus on "powerlessness"; and 6) connection and identification with others as a source of ego-reinforcement (Katz and Bender 1976, 9-11; Katz 1981, 136). This method has been applied in various fields including treatment of addiction and chronic disease (Gartner et al. 1971).

Open Dialogue is a psychiatric treatment which was developed in Finnish Western Lapland and has proved to be effective in reducing schizophrenia (Seikkula et al. 2000). In Open Dialogue, patients, the people in their social networks and crisis intervention teams hold open treatment meetings together, from first contact to the end of the intervention (Seikkula 2002). The aim is "to create a joint space for a new language, in which things can start to have different meanings" (Seikkula 2002, 266).

Töjisha Kenky $\bar{u}^{4}$ is a self-help method that emerged in a psychiatric care community, Urakawa Beteru no Ie (浦河べてるの家; 'Urakawa Bethel House'), in Hokkaido, Japan. In Tōjisha Kenkyū, people get together and 'study' 
themselves in communication with others who may have similar problemspredominantly schizophrenia (Urakawa Beteru no Ie 2005; Kumagaya 2015). It is reported that this method is effective in developing a sense of connectedness based on shared dialogue, as well as an understanding of one's own problems (Ayaya and Kumagaya 2008). It has been applied to various kinds of chronic difficulty, such as addiction or autism (Ayaya and Kumagaya 2008; Kamioka and Ōshima 2010).

The SHG, the object of this discussion, can be seen as a Self-Help Group because: 1) it meets all of the above qualities of a Self-Help Group; 2) it is not a medical treatment and thus cannot be classified as Narrative Therapy or Open Dialogue; and 3) while the terms Self-Help Group and Töisha Kenkyū both refer to general methods and can be used more generally in a variety of situations, it seems that Self-Help Groups are used more often than Töjisha Kenkyū.

\section{OUTLINE OF FIELDWORK}

\subsection{The Field: The SHG}

In the SHG, youth who define themselves as experiencing ikizurasa get together and share their experiences through conversation. The objective is neither for participants to get a job nor to recover from illness, but to collaborate with others in a way that is more focused on self-exploration and examination than everyday communication. Since it began in 2011, the SHG has met mostly once a month in Osaka. Each meeting has approximately ten to twenty participants and takes about four hours. Most participants are in their twenties or thirties, and have experienced one of the following: futōkō (不登校; school non-attendance) ; $^{5}$ unemployment/insecure employment; hikikomori (ひきこもり; isolating oneself in one’s house) ${ }^{6}$; addiction; mental illness; and/or family-related problems.

The meetings take different forms. The most frequently used style is the 'Individual Report', where a self-nominated 'Reporter of the Day' prepares a written text about a specific personal difficulty, to which other participants give feedback by referring to their own experiences. Another popular style is Free Talk, in which participants discuss freely 'The Theme of The Day', focusing on issues such as 'My Fear of Communication'.

The SHG meetings are run with two mentors present: a coordinator and a moderator. Since the program began, I have participated as coordinator in 48 of the 51 meetings, mainly to facilitate the sharing of narratives by interpreting or providing social context for them. The moderator of the SHG 
also established the youth support NPO called 'Generative Garden' in 2006. 'Generative Garden', which runs the SHG, is an 'ibasho' (居場所; a place to 'be'), or a “space with a receptive atmosphere” (受容的な空間) (Abiru 2012, 37), particularly for youths. Ibasho usually means an open (and opened) space where a person is free (but not forced) to participate in any activities and can relate with others in a safe and secure social atmosphere without coercion. Thus, 'Generative Garden' is an ibasho mainly for unemployed youth where they can be without pressure to (find) work. The SHG meetings are open to the public and people can take part as members or otherwise. The moderator organises meetings and also facilitates the generation of narratives.

Although the coordinator and moderator play key roles in the SHG, it is emphasised in all meetings that they are there primarily as participants rather than supporters or specialists.

This follows the 'equal', or less paternalistic, relationship between the client and the therapist that characterises the narrative approach. By contrast, in a traditional therapeutic situation, the relationship is limited to a clearly defined patient-therapist relationship because: 1 ) it is the client who suffers from a problem; and 2) experts are paid for their expertise to take responsibility according to industry standards as skilled practitioners. The mentors in the SHG are neither psychological nor psychiatric specialists, but the mentor has 20 years of experience in supporting futōkō and/or hikikomori children and youth, and the coordinator has 10 years of research experience in this area. Should something go wrong, participants have access to qualified psychological/psychiatric support personnel outside the SHG.

The 'equal' relationships that are a defining characteristic of a Self-Help Group are important because they help participants to feel more comfortable in relating with others, and to address problems through their own initiative, rather than under specialists' directions. Indeed, in a post-industrial neoliberal environment of precarious employment and increased stress, both carer/ supporter/mentor and client are exposed to angst, albeit not at the same level (Beck 1992). Thus, in the SHG meetings, given that the mentors are not paid, the mentors are nearly on the same level as the participants and do not have the same responsibilities or training as a therapist.

\subsection{Methodology and Data Collection}

This research focuses on interpreting the narratives of group participants in a context where the researcher is actively involved in coordinating group meetings. Therefore, it adopts a qualitative methodology (Glaser and Strauss 1967; Flick 2014). It shares the practical attitude of Action Research which is oriented by "change and improvement" (McNiff 2013, 54); in this case, of youth support initiatives currently available in Japan. Action Research basically operates on a continuous cycle of plan-action-reflection, with the researcher(s) involved throughout (Lewin 1946; Elliot 1991; McNiff 2013). 
For this study, the data collected were: 1) participant observations; 2) semistructured narrative interviews with participants; and 3) written text made available by participants, including their 'Individual Reports' and other related written materials. Participant observation of the SHG meetings was conducted from January to October 2015, and ten meetings were observed. For all but one session, held in January during fieldwork in Japan, Skype was used to observe the meetings from Australia. Seventeen in-depth interviews were conducted in January 2015 in Hyogo and Osaka. The interviews were held in cafés, a meeting room in 'Generative Garden', and a university classroom. Each session took approximately 1.5-3 hours. The interviewees were young adults aged in their twenties and thirties who had participated in the SHG at least three times. The interviewees included 3 females and 14 males, and they were each asked to narrate their stories of ikizurasa, their work experience, and how they felt about the SHG, including (if relevant) how their lives had changed due to their participation. The interviews were audiorecorded and transcribed later. Texts that the interviewees had written were used to supplement their narratives.

In the following sections, I discuss two such narratives as case studies, which have been selected for the following reasons: 1) the participants' experiences of angst are typical of those of other interviewees and thus represent a commonly expressed narrative on these topics; and 2) the narrators had been participants of the SHG for a long time, so their commitment to the group had made them particularly articulate and their narratives were more detailed than those of others. $^{7}$

\section{NARRATIVES OF IKIZURASA}

\subsection{Case 1: Mai Sasaki (Female, Aged 26)}

Mai Sasaki [pseud.; b. 1988] started futōkō (school non-attendance) when she was nine years old. Being a good student, she did not have a clear reason for futōkō, but when going to school and being told to get good scores and to act as a model student, she could not help feeling as if she was being "told to become a machine” (機械になれと言われているみたい) (Sasaki 2015a). ${ }^{8}$ Mai comes from a typical middle-class family, consisting of herself, a housewife mother, a salaryman father and a younger sister. Mai's parents did not directly blame or scold her for not attending school, but she keenly felt their strong hope that she would return to school or work. She spent her teenage years mostly isolating herself in her house. When she was 20 , she felt she had no choice but to work and found a job at a post office, and then at a shopping centre as a cleaner. However, she could not bear to act as though she were a robot, and she quit both within two weeks. Blaming herself as "unproductive and not worthy of living” (生産性がなく生きているのが申し訳ない), Mai increasingly found it difficult to enter public spaces and started cutting her wrists. She felt tranquil only when she read books and wrote essays.

7 Some details of the stories have been modified to protect privacy but with due care to not to change the import of the narrative or to interfere with analysis.

8 Hereafter in this section, Mai's words are from Sasaki 2015a unless otherwise indicated. Details of this and other participant data are listed in the Appendix. 
Looking for new human relationships, she searched on the internet and found 'Generative Garden'. She liked the mood of the place, where "No one was keen to rescue me” (誰もがんばって助けようとしない). Recovering her cheer and energy, she attended the SHG meetings and participated in exploring the meaning of her sense of ikizurasa. As one of the earliest and keenest members of the meetings, she wrote 'Individual Reports' several times. The themes of her reports include 'Pain and Anger' and 'Writing Myself Out'.

Asked how the SHG had helped her to change, Mai answered, "I stopped seeing my ikizurasa as negative, and although living is painful I started to feel okay with it” (生きづらい自分を否定的に捉えなくなった。生きづらいんだけじ、い いかって). She continued:

In the early days [of participation], I thought that I was to blame. I felt that it was my fault I was feeling ikizurasa, and that I had to fix it. I had lived in a world where only I and the people around me existed. But ... as I read books and listened to other people's projects, my perception changed. My view started to shift from being 'it's all my fault' to 'there is something that can be shared in my experience'. In such a problematic system, there must be many other people who feel the same pain. ${ }^{9}$

After three years of participation, Mai was offered a job writing articles by a newspaper editor who visited the SHG meetings. She was very happy because it was her dream job, but it was also a new challenge for her. As she worked on the articles, she realised her writing topics had been limited to her personal experiences and perceptions, which might interest those who knew her but not those who did not. In light of this realisation, she started to think, "I am a part of this society ..., even though I sometimes cannot fit into it. If so, I may have to write something related to society” (うまく馴染むことができない側面が あるにしても、私もこの社会の一員。……れなら、社会とつながりのあるものを書 いてみたい) (Sasaki 2015b).

\subsection{Case 2: Kōsuke Noguchi (Male, Aged 27)}

Kōsuke Noguchi [pseud.; b. 1987] was one of the oldest members of the SHG. He was raised in a family which consisted of a salaryman father, a housewife mother and a little sister.

When he was young, Kōsuke did not receive affection from his family. His father was a serious worker, but drank at home and was abusive toward Kōsuke. He started to hate his father and felt lonely. At school, too, Kōsuke did not meet people he could think of as "real friends" (親友) (Noguchi 2015a)..$^{10}$ When he was in junior high school, he started to fear that he had an unpleasant body odour. His mental condition worsened, causing Kōsuke quit school when he was 16. After that, he was obsessed by the idea of what he called "investigating the truth of the universe” (宇宙の真理を探究する) (Noguchi 2012). 
At the age of 18, Kōsuke could not help thinking about being violent toward his father and himself. Trying frantically to find somebody to stop him, Kōsuke called a twenty-four-hour suicide prevention hotline and was introduced to 'Generative Garden'. This encounter changed his life. As he related himself to other members of 'Generative Garden', Kōsuke's violent impulses subsided. He also started to participate in the SHG meetings.

Kōsuke wrote 'Individual Reports' on 'The Relationship between Father and Me' and 'My Mental Illness'. After completing his first report, he experienced a sense of fulfilment and contentment. He wrote:

I felt a warm affection for my own words, which came from the bottom of my heart. I felt that my words gained energy when others reacted positively toward them. [...] Rather than shut them within myself, I felt I wanted to let them travel around others through communication. [...] It also led me to listen to others and make comments on others' projects. ${ }^{11}$

(Noguchi 2015b)

In one report, he analysed his passion towards "the truth of the universe" as admiration for something eternal and absolute, and as "a substitute for the intimate affection which I was denied” (愛されなかった代わり) (Noguchi 2012).

Kōsuke's life changed a lot during his participation in 'Generative Garden' and the SHG. First and foremost, in 2013 he started to work on a regular basis. He worked in disability care for 7 hours a day, 5-6 days a week, and this was his first experience of working regularly. He felt the job fit him well, because he "cannot live in a world where people are always competing to become managers” (課長になるとかいつも競争している世界ではやっていけない), while for him the field of disability care includes "basic human relationships" (普 通の人間と人間の関係). In addition, he left his parents' house and started to live with another male member of the SHG. With distance, his attitude to his father changed: "I could never work for my family without ever complaining like him. I just want to express my gratitude and say to him 'well done”" (彼の ように家族のために……不平も言わず働くことは決してできない。お疲れ様という 感謝の気持ちを示すほかない) (Noguchi 2012).

It seems that the guided self-help experience helped Kōsuke to achieve a positive frame of mind, but he emphasised that this was not an intended consequence. Kōsuke remarked, "My original aims never work out as planned" (最初から ねらいを定めるとうまくいかない). Although he did not expect much from the SHG when he started, he “continued because it was fun”(おもしろかったから 続けてきただけ).

\section{ANALYSIS}

\subsection{What is Happening in the SHG Meetings?}

This section presents an analysis of the changes I observed in Mai and 
Kōsuke through the SHG meetings, based on my participant observations as coordinator. These two cases point to the complex issues faced by youth who are experiencing ikizurasa and prolonged unemployment, and the need for less conventional methods of support. Instead of seeking to activate in the participant a robust and rational outlook, I argue that these cases show how greater self-acceptance through positive feedback from others can be more helpful to the individual in fostering a desire to seek employment and taking interest in other life objectives.

In the early stage, most SHG participants expressed that they felt emotional pain and a sense of isolation. They expressed feeling alienated from a society that seemed to be antagonistic toward them and they felt they could not be understood by others. Painful memories of being rejected by family members or failure in school aggravated feelings of anxiety and impulsive anger. While these emotions were tangible, in the early stage of the meetings participants could not identify their emotional needs or the real causes of their situations. Thus they would interrogate themselves: "Why am I so bad?" (Mai) or "What is the truth of the universe?" (Kōsuke).

In the latter stages, however, this attitude began to shift. Through discussions in the SHG meetings, participants had the opportunity to be listened to with care and to listen to others' frank expressions of their experiences without normative value-judgements. Kōsuke started to "feel an affection for" his narrative as other participants positively accepted it. As she listened to others' stories, Mai realised she was not the only one to suffer from a sense of ikizurasa. These kinds of experiences are common among the SHG participants.

The chance to relate positively with others gave participants the necessary encouragement to redefine negative past experiences and to treat them as subjects of investigation. Mai thus replaced her sense of not fitting in with the notion that there is something structural in her personal trouble. Kōsuke came to regard his violent father as a businessman who worked to support his family and was able to stop hating him. Such redefinition potentially helps participants to (re)generate a new sense of self. Mai redefined herself as "being a part of this society". Kōsuke started to grasp a sense of being accepted by others, which allowed him to recognise the damage caused by his abusive father instead of thinking that he himself was to blame. In this way, they created new self-narratives that they could be proud of, and which were founded in the narratives shared by others around them.

Participation in the SHG meetings also brought about greater clarity in the minds of the participants about their own needs. Vague thoughts such as 'I cannot become like my father' (Kōsuke) or 'I am scared of work' (Mai) became more realistic questions like, 'What would be a suitable mode of work for me?' Thus, employment might become a practical and sustainable option once an identification of personal needs, based on a clearer understanding of one's self, is established. Disability care in Kōsuke's case and writing newspaper articles in Mai's case suggest that they were able to apply themselves when they found appropriate jobs at the right time and at a reasonable pace for them. 


\subsection{Indirect Aim-setting}

A crucial question that emerges from these narrative reconstructions is, what are the conditions that foster such generation of positive narratives? Here it is argued that 'indirect aim-setting' and 'enhancement of dialogue' are key factors. Indirect aim-setting is represented in the fact that the SHG meetings aim to offer participants the opportunity to deeply explore their own experiences in structured dialogues, but do not specifically help them to find a job. Thus, even if the participants finally do find a job, this can be interpreted as a by-product of a clearer understanding of self and trustful relationships with others. This also means that those cases which do not result in finding jobs would not be regarded here as unsuccessful.

Indirect aim-setting is particularly important because it enables all group members, including mentors, to participate. It stimulates dialogue and helps facilitate problem solving. If the direct aim is 'to get a job', there is a clear boundary between the supporters and the supported, and the participants are easily regarded as recipients of support services. This sets up the definition of success as getting a job, and a gap emerges between those who are successful and those who are not. But when the target is for participants 'to address their own problems', the participants are inspired to become active investigators of their lives. The two participants shown in the case studies naturally related themselves to the job world through their experiences in the SHG meetings. Although this was not always the case, there are many other cases where participants reported similar experiences.

Although it is crucial that mentors facilitate communication in meetings, it is also important that other participants can provide help as peers and feel equally invested in the group. It was observed that this process almost inadvertently brought back participants' pride, regenerated a sense of capacity, and rekindled excitement in living with a sense of autonomy in their own lives. These qualities are seriously lacking in the conditions typically established in support services.

Indirect aim-setting is also an important characteristic of an ibasho or place to 'be' (Araya 2012, 234), of which 'Generative Garden' is one. In the context of youth support, an ibasho is structured to avoid setting short-term goals, such as going (back) to school or work, and allowing people to focus on resting in an environment free from pressure. This attitude of 'offering no explicitly productive activities' can, in appropriate circumstances, help people develop self-esteem, through which they can begin to think of ways to relate to society (NPO Tōkyō Shūre 2000; Tsutsui et al. 2014).

\subsection{Enhancement of Dialogue}

A narrative produces positive impact when it is supported by people who listen to it carefully and respond to it positively. When it is reinforced through another's genuine acknowledgement, the narrator feels greater confidence in its validity. In order for this to happen, the SHG protocol emphasises that: 1) 
comments should start with 'I' as much as possible (e.g., 'I do not think so' instead of 'It is not true'); 2) value judgements should be minimised as much as possible in responses (e.g., 'You really had a hard time when you didn't go to school' instead of 'School non-attendance is bad'); 3) in responding to a narrative, the respondent then shares their story (e.g., 'That sometimes happens to me, too. In my case ... '). While the mentors participate in this process, they also guide the conversations to ensure that they remain within these parameters.

Seikkula (2002) argues that while speech or a story is produced by an individual, dialogue is "a process", a primary outcome of which is to create relationality (266). Thus, in enhancing dialogue, relationships are focused on more than what is narrated or whose narrative it is. The self which is (re) constructed in this process can be seen as a "relational being", as proposed by Gergen (2009). Challenging the concept of the individual as an entirely free and rational entity who takes all responsibility for their actions, Gergen understands human beings as products of multiple relationships, and argues that knowledge or recovery that is brought about by social practices such as education or therapy, and is not an individual achievement but rather a fruit of effective co-action (Gergen 2009, 240-309). The SHG facilitates selfexploration for young people by creating a forum for hearing and accepting each other's narratives, allowing a kind of relationality to be achieved. Thus, it seems that the enhancement of dialogue fosters more positive self-images in young people who experience angst in their work and living conditions.

\section{CONCLUSION}

In this article I have examined the angst of youth (ikizurasa) in post-industrial Japan. I have focused on a specific Self-Help Group through participant observation to identify the characteristics of a practice that can, within limits, support such youth. From interviews and other material collected through the group's meetings, I found that angst was experienced as the disintegration of a person's mental and physical health, and their relationships with family members and society. I have argued that the main problem of youth who experience such angst is their lack of a robust sense of self and an inability to clarify their needs, which seriously hampers them in utilising existing governmental support programs. As an alternative, this article has shown the effectiveness of a Self-Help Group. This effectiveness is based on: 1) indirect aim-setting, in which participants do not aim at finding a job but at sharing narratives, so as to create the conditions for them to engage subjectively in the group meetings at their own pace and often with pride and a sense of fun; and 2) enhanced dialogue, involving the creation of relationships where participants volunteer their personal experiences, which are carefully heard and receptively responded to.

Unfortunately, in the institutional setting of Japan today, government youth support programs are established in a more paternalistic relationship, where the aims are to directly find clients jobs and the existing framework of activation policies presupposes fully self-reliant individuals. A new framework 
of relation-oriented practices is needed to support unemployed youth, where the aims are to help the individual come to accept themselves and better clarify their needs. It is being gradually realised by local governments that having more human relationships can be effective for career development (Tsutsui et al. 2014, 204).

The observations of particular experiences of youth angst in this article are not unique to Japanese society and are typical to post-industrial societies where there are conditions of casualised work and unemployment. Similarly, my methodology is shared by other Self-Help Group practitioners in these societies. If we are to address the issue of youth angst properly, I contend that it is necessary for us to redefine unemployment itself: to move from seeing it as a temporary situation and to recognise instead that it is a chronic and structural reality that affects a substantial section of society. As indicated in the discussion of the two case studies, a narrative approach can be used to help youth whose precarious socio-economic conditions aggravate their experience of angst, by giving them the opportunity to find support through open, trusting and focused discussions with others.

To focus on narratives and individual identities does not, however, mean ignoring political responsibility for the socio-economic conditions that youths are exposed to. It is vital to recognise that not only a change in personal narratives but also a change in labour conditions is pivotal to minimising youth marginalisation in post-industrial societies. Self-Help Groups and ibasho complement existing therapeutic programs and government activation programs. In order to address and ameliorate the "alienation of the soul" (Berardi 2009, 23) that is typical to late-capitalist societies, it is a pressing priority to deliver support that can be effective for the well-being and career development of different kinds of young people.

\section{APPENDIX: LIST OF INTERVIEWS AND ESSAYS FROM THE FIELD}

Noguchi, K. [pseud.]. 2012. Individual Report. In SHG Meeting Reports 1.

2015b. Support documentation for interview. Addressed to the researcher.

2015a. Interview by the researcher. Digital recording in Japanese. January 12.

Sasaki, M. [pseud.]. 2015a. Interview by the researcher. Digital recording in Japanese. January 11.

2015b. Individual Report. In SHG Meeting Reports 3.

\section{GLOSSARY}

hikikomori (ひきこもり)

a person who isolates themselves inside their house and does not participate in society, or the state of doing so; becomes a problem by the late twenties 
lit., a place to 'be'; an open (and opened) space where a person is free to participate

in any activities and can relate with others in a safe and secure social atmosphere

without coercion

\section{ikizurasa (生きづらさ)}

lit., 'pain of living'); a form of anxiety or angst experienced by youth in post-industrial Japanese society, often associated with a sense of disconnectedness and self-blaming or suicidal tendencies

futōkō (不登校)

school non-attendance for reasons other than illness or economic problems

\section{Tōjisha Kenkyū (当事者研究)}

'Self-Directed Study'; a self-help method that emerged in a psychiatric care community in Japan where people get together and 'study' themselves in communication with others who may have similar problems

\section{REFERENCES}

Abe, A. [阿部 彩]. 2011. Jakusha no ibasho ga nai shakai: Hinkon, kakusa to shakaiteki hōsetsu[弱者の居場所がない社会: 貧困・格差と社会的包捸]. Tokyo:Kōdansha Gendai Shinsho [講談社現代新書].

Abiru, K. [阿比留 久美]. 2012. “Ibasho” no hihanteki kentō” [「居場所]の批判的検討]. In Wakamono no ibasho to sanka: Yūsu wāku ga kizuku arata na shakai [若 者の居場所と参加一ユースワークが築く新たな社会], edited by H. Tanaka [田中 治彦] and K. Hagiwara [萩原 健次郎], 35-51. Tokyo: Tōyōkan Shuppansha [東洋観出版社].

Allison, A. 2013. Precarious Japan. Durham and London: Duke University Press. http://dx.doi.org/10.1215/9780822377245

Amamiya, K. [雨宮 処燷]. 2007. Ikisasero!: Nanmin-ka suru wakamono tachi [生きさ せろ!：難民化する若者たち]. Tokyo: Ōta Shuppan [太田出版].

Amamiya, K. [雨宮 処凛] and T. Kayano [萱野 稔人]. 2008. Ikizurasa ni tsuite: Hinkon, aidentiti, nashonarizumu [生きづらさについて:貧困、アイデンティテ イ、ナショナリズム]. Tokyo: Kōbunsha Shinsho [光文社新書].

Anderson, H. and H. Goolishian. 1992. "The Client is the Expert: A Not-knowing Approach to Therapy." In Therapy as Social Construction, edited by S. McNamee and K. Gergen, 25-39. London: Sage.

Araya, S. [新谷 周平]. 2012. “Ibasho o umidasu 'shakai' no kōchiku” [居場所を生み 出寸「社会」の構築]. In Wakamono no ibasho to sanka: Yūsu wāku ga kizuku arata na shakai [若者の居場所と参加一ユースワークが築く新たな社会], edited by H. Tanaka [田中 治彦] and K. Hagiwara [萩原 健次郎], 231-47. Tokyo: Tōyōkan Shuppansha [東洋観出版社]. 
Ayaya, S. [綾屋 紗月] and S. Kumagaya [熊谷 晋一郎]. 2008. Hattatsu shōgai tōjisha kenkyū: Yukkuri teinei ni tsunagaritai [発達障害当事者研究：ゆっくりてい㸚 いにつながりたい]. Tokyo: Igaku Shoin [医学書院].

Beck, U. 1992. Risk Society: Towards a New Modernity. Translated by M. Ritter. London: Sage.

Berardi, F. B. 2009. The Soul at Work: From Alienation to Autonomy. Translated by F. Cadel and G. Mecchia. Cambridge, MA: Semiotext(e).

Cabinet Office. 2012. Wakamono no kangaekata ni tsuite no chōsa [若者の考え方 についての調査]. Tokyo. Accessed 14 February, 2016. http://www8.cao.go.jp/ youth/kenkyu/thinking/h24/pdf_index.html.

Duell, N., D. Grubb, S. Singh and P. Tergeist. 2010. "Activation Policies in Japan." In OECD Social, Employment and Migration Working Papers, 113. London: OECD Publishing.

Elliot, J. 1991. Action Research for Educational Change. Buckingham: Open University Press.

Flick, U. 2014. An Introduction to Qualitative Research. 5th edition. London: Sage.

Furlong, A. and F. Cartmel. 2006. Young People and Social Change. New York: McGraw-Hill.

Gartner, A., M. C. Kohler and F. Riessman. 1971. Children Teach Children: Learning by Teaching. New York: Harper and Row.

Gergen, K. 2009. Relational Being: Beyond Self and Community. New York: Oxford University Press.

Glaser, B. and A. Strauss. 1967. The Discovery of Grounded Theory: Strategies for Qualitative Research. Chicago: Aldine Publishing Company.

Hijikata, Y. [土方 由紀子]. 2010. “Kodomo no ikizurasa to wa nani ka: Risuku shakai $n i$ okeru futōkō” [子どもの生きづらさとは何か：リスク社会における不登校]. Nara joshi daigaku shakaigaku ronshü [奈良女子大学社会学論集] 17: 259-76.

Japan Business Federation [日本経営者団体連盟]. 1995. “Shin-jidai no 'nihon-teki keiei': chōsen subeki hōkō to sono gutai-saku” [新時代の「日本的経営」： 挑戦 すべき方向とその具体策]. Tokyo.

Kamioka, H. [上岡 陽江] and E. Ōshima [大嶋 栄子]. 2010. Sonogo no fujiyū: 'Arashi' no ato o ikiru hito-tachi [その後の不自由: 「嵐」のあとを生きる人たち]. Tokyo: Igaku Shoin [医学書院].

Katz, A. H. 1981. "Self-Help and Mutual Aid: Emerging Social Movement?". Annual Review of Sociology 7 (1): 129-55. http://dx.doi.org/10.1146/annurev. so.07.080181.001021

Katz, A. H. and E. I. Bender. 1976. The Strength in Us: Self-help Groups in the Modern World. New York: New Viewpoints. 
Kubo, H. [久保 紘章]. 2004. Serufu herupu gurūpu: Tōjisha e no manazashi [セルフへ ルプ・グループ： 当事者へのまなざし]. Tokyo: Aikawa Shobō [相川書房].

Kudō, K. [工藤 啓] and R. Nishida [西田 亮介]. 2014. Mugyō shakai: Hataraku koto ga dekinai wakamono tachi no mirai [無業社会：働くことができない若者たち の未来]. Tokyo: Asahi Shinsho [朝日新書].

Kumagaya, S. 2015. “Tojisha Kenkyu of Autism Spectrum Disorders.” Advanced Robotics 29 (1): 25-34. http://dx.doi.org/10.1080/01691864.2014.967723

Lewin, K. 1946. “Action Research and Minority Problems.” Journal of Social Issues 2 (4): 34-46. http://dx.doi.org/10.1111/j.1540-4560.1946.tb02295.x

MEXT (Ministry of Education, Culture, Sports, Science and Technology). 2015. Heisei 26 nendo jidō seito no mondai-kōdō tō seito-shidō-jō no shomondai ni kansuru chōsa [平成26年度 览童生徒の問題行動等生徒指導上の 諸問題に関する調査]. Tokyo. Accessed 19 October, 2015. http://www.mext. go.jp/b_menu/houdou/27/09/1362012.htm.

MIAC (Ministry of International Affairs and Communications). 2014. Labour Force Survey [労働力調査]. Tokyo. Accessed 19 October, 2015. http://www.stat. go.jp/data/roudou/longtime/03roudou.htm.

McNiff, A. 2013. Action Research: Principles and Practice. 3rd edition. New York: Routledge.

Noguchi, Y. [野口 裕二]. 2002. Monogatari to shite no kea: naratibu apurōchi no sekai e [物語としてのケア:ナラティブ・アプローチの世界へ]. Tokyo: Igaku Shoin [医学書院].

2009. Narativu apurōchi [ナラティヴ・アプローチ]. Tokyo: Keisō Shobō [勁草 書房].

NPO Tōkyō Shūre [NPO法人東京シューレ]. 2000. Furīsukūru to wa nani ka: kodomo ga tsukuru, kodomo to tsukuru [フリースクールとは何か：子どもが創る・子ど もと創る]. Tokyo: Kyōiku Shiryō Shuppankai [教育史料出版会].

OECD (Organization for Economic Co-operation and Development). 2013. Employment Outlook. OECD Publishing.

2014. "Labour Market Statistics.” In Main Economic Indicators (database). Accessed 19 October, 2015. http://dx.doi.org/10.1787/data-00046-en

Oguma, E. [小熊 英二]. 2014. “Sōsetsu” [総説]. In Heisei-shi [平成史], edited by E. Oguma, 13-97. Tokyo: Kawade Shobō [河出書房].

Saitō, T. [斎藤 環]. 1998. Shakaiteki hikikomori: Owaranai shishunki [社会的ひきこも り：終わらない思春期]. Tokyo: PHP Shinsho [PHP新書].

Satō, T. [佐藤 俊樹]. 2000. Fubyōdō shakai Nippon [不平等社会日本]. Tokyo: Chūkō Shinsho [中公新書]. 
Seikkula, J. 2002. "Open Dialogues with Good and Poor Outcomes for Psychotic Crises: Examples from Families with Violence." Journal of Marital and Family Therapy 28 (3): 263-74. http://dx.doi.org/10.1111/j.1752-0606.2002. tb01183.x

Seikkula, J., B. Alakare and J. Aaltonen. 2000. "A Two-year Follow-up on Open Dialogue Treatment in First Episode Psychosis: Need for Hospitalization and Neuroleptic Medication Decreases." Social and Clinical Psychiatry 10: $20-29$.

Standing, G. 2011. The Precariat: The New Dangerous Class. London \& New York: Bloomsbury.

Tachibanaki, T. [橘木 俊昭]. 2006. Kakusa shakai: Nani ga mondai na no ka [格差社 会: 何が問題なのか]. Tokyo: Iwanami Shinsho [岩波新書].

Tsukino, K. [月乃 光司]. 2007. Byōki dayo! Zen’in shūgō [病気だョ! 全員集合]. Tokyo: Shinkigensha [新紀元社].

Tsutsui, M. [筒井 美紀], J. Sakurai [櫻井 純理] and Y. Honda [本田 由紀]. 2014. Shūrō shien o toinaosu: Jichitai to chiiki no torikumi [ 就労支援を問い直す：自治体 と地域の取り組み]. Tokyo: Keisō Shobō [勁草書房].

Urakawa Beteru no Ie. [浦河べてるの家]. 2005. Beteru no ie no 'tōjisha kenkyū' [ベて るの家の「当事者研究]]. Tokyo: Igaku Shoin [医学書院].

Weil, S., D. Wildemeersch and T. Jansen. 2005. Unemployed Youth and Social Exclusion in Europe. Surrey: Ashgate.

White, M. and D. Epston. 1990. Narrative Means to Therapeutic Ends. New York: W. W. Norton \& Company.

Yuasa, M. [湯浅 誠]. 2008. Han hinkon: “Suberidai shakai” kara no dasshutsu [反貧 困：「寸べり台社会」からの脱出]. Tokyo: Iwanami Shinsho [岩波新書].

Yuasa, M. [湯浅 誠] and Nihei, N. [仁平 典弘]. 2007. “Jakunen hōmuresu: 'Iyoku no hinkon' ga teikisuru toi” [若年ホームレス:「意欲の貧困」が提起する問い]. In Wakamono no rōdō to seikatsu sekai: Karera wa donna genjitsu o ikiteiru no ka [若者の労働と生活世界：彼らはどんな現実を生きているのか], edited by Y. Honda [本田 由紀], 329-62. Tokyo: Ōtsuki Shoten [大月書店]. 


\title{
Performing Femininity in Japanese Politics: Chikage Ōgi Case Study
}

\author{
ALISON LUKE \\ Macquarie University
}

\section{ABSTRACT}

Women's access to the political sphere in Japan has been limited by structural constraints which perpetuate their roles primarily as housewives and mothers. Some women who seek to become professional politicians use these images of traditional femininity as a deliberate tactic in political campaigns to provide a culturally acceptable way for them to express their political views. This paper analyses the life of Chikage Ōgi, a Japanese politician who was once a Takarazuka actress, in order to develop a deeper understanding of the ways in which gender-role expectations restrict women's access to opportunities throughout their life course and the pragmatic ways that women strive to achieve their goals despite this. Ögi used the performance skills she developed during her time as an actress to enhance her political image and fulfil her political ambitions. This paper highlights Ögi's creativity in enacting agency in Japan's male-dominated political sphere and demonstrates the complex ways she both upheld and subverted gender norms in order to achieve political longevity.

\section{KEYWORDS}

Chikage Ōgi; femininity; gender; history; politics; performance; Takarazuka; women
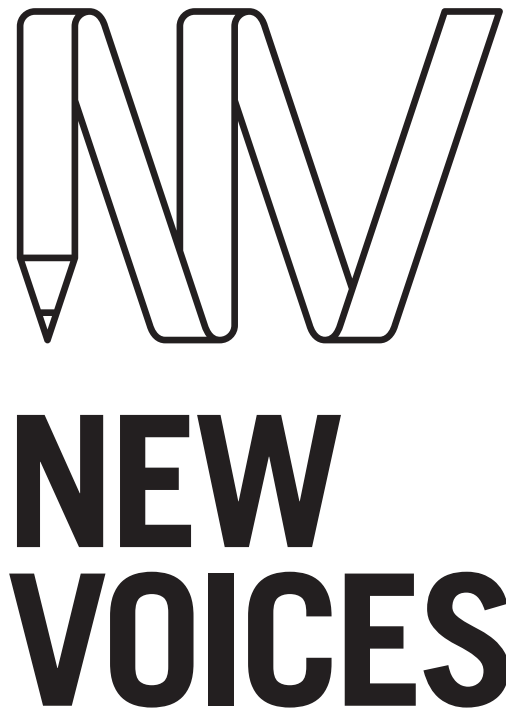

IN JAPANESE STUDIES

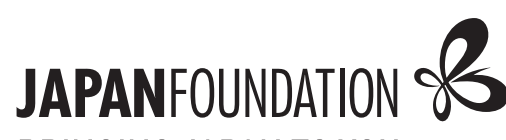

BRINGING JAPAN TO YOU

To link to this article:

http://dx.doi.org/10.21159/nvjs.08.06

\section{ISSN 2205-3166}

New Voices in Japanese Studies is an interdisciplinary, peer-reviewed journal showcasing the work of emerging scholars from Australia and New Zealand with research interests in Japan.

All articles can be downloaded free at newvoices.org.au

(c) The Japan Foundation, Sydney and Alison Luke, 2016

\section{(c) (1) $(-)$}




\section{INTRODUCTION}

Japanese politics have long been dominated by men, and the presence of women in the political sphere is treated as both a novel and unnatural occurrence. This is particularly the case in conservative political parties that wish to maintain the status quo of Japan's “old-boys club” (Mackie 1989; Dalton 2008a). Many scholars have noted persistent gender inequality in Japan's political system as women continue to be under-represented in politics (Dalton 2015; Eto 2010; Tachibanaki 2010). Although this is by no means unique to Japan, it is notable that women are often subjected to gender-based criticism and public heckling by male politicians motivated by an underlying belief in women's primary roles as housewives and mothers (Japan Today 2014; Dalton 2008a). The existence of such social norms and gender roles places women at a significant disadvantage because they restrict women's access to resources and support systems throughout their life course which may otherwise enable them to ascend to positions of power and realise their goals. In the political world, women's lack of access to inner circles of power in general has meant that female politicians are kept out of association with "dirty" politics and are connected with an image of "clean" politics (Derichs et al. 2006, 248; see also Iwao 1993). This image persists, even though some powerful female politicians (i.e., cabinet ministers) have been involved in political scandals. It persists because, in the dominant gender discourse, women have continued to be perceived as political outsiders, such that "men are the norm and women are the 'other"' (Dalton 2015, 99; see also Dalton 2011).

Political parties comprising mainly of male members have exploited female politicians as "token" candidates in their political campaigns (Rosenthal 2008) and prefer to limit their political involvement to areas deemed appropriate for women. Utilising women as political assets distracts voters with an image of change or reform without actually improving women's status. This has tended to reinforce stereotypes about women's political (in)ability, as the majority of candidates fielded in this manner are not re-elected. Male-centric political parties seem unconcerned by issues of gender equality, and view women's political presence as a way to reinforce social norms through political rolemodeling while constructing an image that may appeal to more voters.

This paper explores the career of Chikage Ōgi ${ }^{1}$ [扇 千景; b. 1933], a former performer with the Takarazuka Revue (an all-female musical theatre company), actor and television host who became a politician. Her career highlights the ways that political parties, and indeed female politicians themselves, utilise idealised femininity to achieve political objectives. It examines the way that Ögi, like many other women, responded to a male-dominated political culture by leveraging gender norms and her normative roles as a housewife and mother of two to show her suitability and trustworthiness to her electorate. However, while Ōgi adopted a typical feminine image in her demeanour and attire, aspects of her behaviour demonstrate a rejection of gender norms. Ōgi's 
political tactics, if not her political direction, have been strongly connected with her early life experiences where she developed an understanding of the value of gender performativity through her family and her Takarazuka training.

The first section of this paper introduces Ōgi's pre-political experiences, using a feminist understanding of the 'life course'. This concept pertains to gendered ways in which socio-cultural contexts restrict access to opportunities (Bengsten and Allen 1993, 492-93). It is used here to analyse the way Ögi enacted agency within these constraints to overcome the challenges she faced. This framework helps to understand the gendered challenges women face in Japan, and how these can manifest in politics. It draws on the four main ontological assumptions underpinning a life course perspective as defined in the work of Elder (1998) and summarised below:

1. An individual's opportunities and constraints are influenced by and must be understood within their cultural and historical contexts;

2. There is an interdependency between the individual and their close relations (i.e., family/friends), recognising the family as the basis of socialisation;

3. Individuals have agency and enact choices within the constraints and expectations of their cultural and historical circumstances;

4. The timing of events, including turning points and transitions, has immediate and long-term effects on the trajectory of the life course.

The final section of this paper discusses Ögi's political career and how her prior life experiences are reflected in her political performance. This will include a visual analysis of Ögi's appearance in a selection of Cabinet photographs from 2000 to 2002 which compares Ōgi with her female colleagues. While a detailed analysis of Ōgi's political decisions and policies is beyond the scope of this paper, I will argue that this illustrates the way that Ögi has maintained certain social expectations through her presentation as 'feminine', even though her actions often subverted such gender norms.

\section{INFLUENCE OF FAMILY ON EARLY LIFE EXPERIENCES}

Ōgi's early childhood experiences and family attitudes played a large role in shapingherself-perception and lifegoals. Thelife-courseperspectiveemphasises the importance of childhood in determining access to opportunities due to cumulative advantage or disadvantage (Hutchinson 2001). Ögi's position as a daughter in a family that supported the maintenance of traditional gender roles determined her access to education and work opportunities. According to Ōgi, her personal wartime experiences also exercised a lasting impact by motivating her to pursue peace in her political career. I will analyse aspects in Ögi's early life as they influenced the development of her character and future career goals. 
Chikage Ögi was born in Kobe in Hyogo prefecture on 10 May 1933, as the third daughter of Matsutarō (father) and Misae (mother) Kimura. She was born in a time of fervent nationalism during the Meiji period [1868-1912] which culminated in Japan's participation in the Second Sino-Japanese War [19371945] and the Pacific War [1941-1945] (Morton and Olenik 2005). As Japan's expansion throughout Asia-Pacific was driven back, the Allies launched a series of attacks from the air and sea on mainland Japan, which included Ōgi's hometown of Kobe (United States Strategic Bombing Survey 1947). Eleven yearold Ōgi survived. As Ōgi identified, "this [evacuation] experience is my origin as a politician” (この [疎開] 体験こそが、私の政治家としての原点なのです) (Ōgi 2001, 36). ${ }^{2}$ These experiences putatively motivated her to strive for peace and bring an end to warfare (Shimazaki 2006, 62). Actively working towards peace is an important step in protecting both women and men from disadvantage. It also protects women from the exacerbation of existing gender inequality and vulnerability (Banerjee 2010, xvi). These somewhat stereotypical comments of Ōgi's, as favoured by but not limited to female politicians, tend to reinforce associations between 'peace' and femininity (Banerjee 2010, xiii).

Confucian values served an essential role in the construction of gender roles during the Meiji period. This institutionalised the existing ie (家) or stem family system (Ueno 2009), which was central to social organisation in this period. The government considered adherence to these roles as vital in strengthening national identity and economic development toward its multiple war efforts (Nocedo 2012, 2). This was reinforced by a normative division of labour, with men placed at the head of the family as the "bread winners" in the "public sphere" while women were to be good wives and wise mothers who belonged at home in the "private sphere" (Lebra 2007a, 249). Women's educational institutions strongly promoted this as an ideal, even though it was not the reality for many women who had to work outside the home due to economic necessity (Nocedo, 2012; Reitan 2011). The example of Matsutarō and Misae Kimura was no different from this breadwinner/housewife paradigm, as Matsutarō worked as a bank employee while Misae managed the household. Matsutarō Kimura promoted Ōgi's adherence to strict gender roles (Shimazaki 2006,62 ), meaning that approved life choices were limited and she lacked access to opportunities to develop alternate possible selves.

Ōgi's family life was shaped by these values and gendered expectations (Ōgi 2008). Ōgi graduated from Hyogo Prefectural Kobe High School (兵庫県立神 戸高等学校) in 1952 and aspired to enter university (Kobayashi 2014, 52-53). She achieved high grades in her exams and it was recommended that she enrol in Kobe University (神戸大学) (Ōgi 2008, 158). Ōgi wished to enrol in Kobe University's Department of Architecture and become an interior designer but her “father stood in front of such a dream” (そんな夢の前に父の一言が立ちはだ かった) (Ōgi 2008, 158). His disapproval was based on how Ōgi’s choice would negatively affect her ability to uphold gender norms and expectations. Her father disapproved of Kobe University as a mixed-gender institution and told her, "You'll begin to keep bad company so only a woman's college is allowed" (虫がつくから女子大しかダメ) (Shimazaki 2006，62). Ōgi’s father preferred women's colleges as they served to prepare middle-class women for future 
roles as mothers and housewives (Uno 2005). He stated, "If you become a tomboy you won’t become a wife” (おてんばになったら嫁のもらい手がなくなる) (Ōgi 2008, 158). Ōgi's father wished for her to work as a secretary and refused to pay her tuition, thus making her unable to attend university (Kobayashi 2014). In this way, a strong paternal influence in a patriarchal family system can limit a child's access to educational opportunities (Lebra 2007b). This made it difficult for Ōgi to seek a career outside of prescribed gender roles. Under these limiting circumstances, Ōgi went on to enter the Takarazuka Music School (宝塚音楽学校) and Takarazuka Revue (宝塚歌劇団), which ultimately paved the way for her career as a performer and public personality.

\section{BECOMING A TAKARASIENNE}

There was an element of chance in Ögi's decision to enter the Takarazuka Music School in 1952 and become a 'Takarasienne. ${ }^{3}$ As Ōgi "did not have the courage to work part-time to earn the tuition” (アルバイトで学費を稼いで大学 に行く勇気もない) (Ōgi 2008, 158), her friend’s older sister suggested that she try out for Takarazuka Music School and secretly sent in an application on her behalf (Kobayashi 2014). Ōgi had no longing for the entertainment industry and had never thought of performing before, but at her friend's insistence and out of her own curiosity she took an audition (Ōgi 2008, 158-59). She had preferred theatre study group over tennis in high school, and her childhood music and dance lessons served her well (Shimazaki 2006, 62). Although Ōgi was still unsure of her feelings she decided to go ahead and without any preparation she passed the exam (Ōgi 2008, 159). She then succeeded in the interview without knowing any current Takarazuka stars when asked. Her father was furious when she told him she had been accepted into the school and planned to perform in the Revue. Despite this, she completed her training and joined the Takarazuka Revue in 1954, ranking fourth out of the fiftyone students in the 41st graduating class (Kobayashi 2014). Ögi demonstrated agency in this decision, contesting the objections of her parents: "adults had unreasonably restrained me before and now there was a surge in my rebellious spirit”(無理やり抑えにかかる大人たちを前にして、反抗心がわきあがってきた。よ し、それなら宝塚に行ってやる) (Ōgi 2008, 160). Ōgi’s motivation to disobey her father was also due to the decent income offered to performers in the Revue, which would allow her financial independence from her family. This was an important turning point in her life-course trajectory as it offered access to a wider range of opportunities and increased her cultural capital.

The Takarazuka Revue is an all-female performance company established in 1913 by entrepreneur and politician Ichizō Kobayashi [1873-1957] as a business strategy to increase passengers on his railway line to a town of the same name (Robertson 1991). Performers were (and still are) restricted by age, and required to remain unmarried for the duration of their career with the Revue. As was the case with Ōgi, most girls came from privileged backgrounds (i.e., from middle/upper class families) (Robertson 1998) as the two years of group vocal and theatrical training to become a Takarasienne was expensive.

3 'Takarasienne' is a nickname for Takarazuka performers. It plays on 'Parisienne', in acknowledgement of the 
This suggests that Ōgi's parents must have contributed to her tuition despite their objections, although renewed conflict upon her graduation (Ōgi 2008, 160) also suggests that they did not anticipate her actually performing in the Revue.

The Takarazuka Revue (also known simply as 'Takarazuka') is still active and popular in Japan today. It has five performing troupes and their leading stars are designated as either otokoyaku (男役; lit., 'male role') or musumeyaku ( 娘役; lit., 'daughter role'). Performers specialising in either role may later graduate to older female roles, known as onnayaku (女役; lit., 'woman role'). The term 'onnayaku' has also been used by fans and Takarasiennes to elevate musumeyaku to the same status as otokoyaku (Robertson 1992, 182). Takarazuka performances attract an almost entirely female audience (upwards of 90 percent), with large fan bases which develop around the otokoyaku performers (Brau 1990, 80). Singer $(1996,167)$ asserts that the otokoyaku classification is coveted by Takarasiennes because usually only these performers become top stars and can earn the highest wages. Within each of the company's five troupes, a limited number of women are selected as the otokoyaku leads, and they usually remain in these coveted and higherpaid positions for the duration of their careers. Otokoyaku may occasionally be called upon to play strong female roles as well, mainly to capitalise on their popularity. The remaining positions are filled by more junior otokoyaku or those who perform musumeyaku, some of whom become female leads and form a so-called "golden combination"-an otokoyaku and musumeyaku pairing who appear together in many performances (Singer 1996). Others take character roles of either sex.

Ōgi was designated as a musumeyaku performer. These roles allowed her to cultivate a feminine repertoire, utilising codified feminine behaviours such as exaggerated mannerisms, vocalisation and visual cues (Brau 1990, 86). As a musumeyaku, one must focus on cultivating qualities of femininity-such as long hair-that are aesthetically prized in Japan. Musumeyaku must also possess attributes that have come to be valued in Takarazuka's repertoire of femininity and which distinguish them from their otokoyaku counterparts, including a soprano voice and unnaturally high vocalisation, physically restricted and graceful movements, and specific colours and patterns used in costuming-for example, pink (Ueda 1974, 97-9). The Takarazuka motto, “Kiyoku, tadashiku, utsukushiku” (清く、正し<、美しく), meaning "With purity, honesty, [and] beauty," strongly reflects the school's ideals of femininity (Takarazuka Music School 2015). Language use is another point of differentiation between otokoyaku and musumeyaku: once designated as otokoyaku, performers use masculine language forms within their performances, although it is made clear that this is not to carry over into their daily lives (Robertson 1998, 73).

The gendered language and terminology used in Takarazuka (such as 'musume'), reinforced normative familial roles as part of Kobayashi's structuring of his company. As is typical in the more traditional performing arts and other group structures in Japan, all Takarasiennes are referred to as 'seito' (生徒; student/s), while Kobayashi was referred to as 'otōsan' (お父 
さん; father) and their instructors as 'sensei' (先生; teacher). Takarazuka performers continued to call themselves students even after they graduated and began performing as professionals. This arguably denies them maturity, de-sexualising them in the permanent role of young women (Robertson 1998, 16; Yamanashi 2012, 36). Youthfulness and purity are key ideals which are reinforced by the strict relationship criteria which stipulate that performers must remain unmarried (Robertson 1998, 16). As distinct from the Kabuki ${ }^{4}$ term 'onnagata' (女形; lit., 'woman role'), which describes male actors playing female roles, the use of 'musume' (娘; lit., 'daughter', also used colloquially to mean 'young girl') creates an impression of innocence and dutifulness within a Japanese patriarchal family structure (Robertson 1998, 14).

As is the same in most performing arts forms, Takarazuka performances present idealised depictions of both men and women, only with an allfemale cast. Such performances can potentially reflect the constructed nature of gender as the performing body can exemplify, appropriate and denaturalise normative modes of masculinity and femininity. Takarazuka's practices-again, as in most theatre arts-demonstrate that enacting gender is a skill that is consciously taught and reinforced through repeated actions (Stickland 2004). This performance of gender has the potential to undermine a patriarchal conception of gender relations as it becomes clearer that gender is the result of learned behaviour and not biological difference. Beyond the stage, Takarazuka training instilled a regime of behavioural criteria so as to align the performers with Kobayashi's desire to produce "strictly wholesome entertainment" (Singer 1996, 162). But despite this gendered approach, the cultivation of personality in the performances and training in individual expression (although heavily coded) meant that Takarazuka moved beyond the focus of most women's colleges at the time, which was to prepare women for marriage and motherhood (Yamanashi 2012, 38). Nevertheless, Kobayashi's intention was not to empower women through their self-development but to make them more appealing as future wives and mothers. This would have also served a practical purpose by ensuring the success and profitability of the Revue as a business through the appeal of these idealised images to middleclass and conservative audiences.

The portrayal of gender and sexuality within Takarazuka exaggerates the gender constructions within Japanese society and stereotypically reflects dominant masculinity. Despite an all-female cast, the management and artistic direction of the company is controlled almost exclusively by men (Berlin 1991, 46). The storylines of Takarazuka plays are also male-centric, as female characters are cast in supporting roles for otokoyaku leads (Robertson 1998 , 12). Even though women perform the otokoyaku roles, Kobayashi indicated that his intention was to glorify masculinity and showed no concern for expanding the range of possible selves for women (Robertson 1998, 17). Clearly, entrenched social norms at the time made it relatively difficult for women to escape from social expectations that they would assume the role and responsibilities of housewife. According to Kobayashi, Takarazuka training is supposed to create the ideal wife, as it allows the performers to understand male desires through their portrayal of male characters, as well as understand 
how to successfully satisfy their husband's expectations through performing complementary female roles (Chen 2010, 55).

One of the most visible and lasting effects of Ōgi's time as a Takarasienne is the continued use of her stage-name, which became a permanent part of her identity and public persona during her political career. Before making her debut as a Takarasienne, each student must choose the stage name (芸 名) that she will use during her career, although birth names are maintained for private and legal purposes (Stickland 2004, 179). There is a strict process for the selection and approval of these names: they must reflect the aesthetic values of the School and must not be too similar to the student's original name or another performer's stage name. Inspiration is to be drawn from a variety of sources, including poetry and nature-both as a reflection of Kobayashi's literary tastes and as an allusion to the Takarasienne's artistic character (Stickland 2004, 180).

The selection of a name is intended to reflect the performer's persona and connect them with the principles of Takarazuka. In Ögi's case, the surname 'Ōgi' (扇) comes from the Japanese word for "folding fan," which is a key instrument used in Takarazuka choreography (Brau 1990, 85). Her personal name, 'Chikage' (千景), is a combination of the character for 'thousand' with the character for 'vista' or 'view'. Her stage name can thus be read as a poetic visual device to elicit an image of 'views of a thousand fans', symbolising the beauty of a Takarazuka performance. Ōgi's adoption of this stage name is emblematic not only of her professional development as a performer, but also of her growing agency and independence from her parents.

\section{MARRIAGE, MOTHERHOOD AND RETURNING TO FILM: LIFE AFTER TAKARAZUKA}

In 1957, Ögi retired from the Takarazuka Revue so that she could marry Kōtarō Hayashi [林 宏太郎; b. 1931], a famous Kabuki actor known publicly as Tōjūrō Sakata IV (四代目坂田藤十郎), who inherited the tradition from his family as is customary in Kabuki. They married in 1958 and Ōgi formally adopted his surname, becoming Hiroko Hayashi, while maintaining her Takarazuka stage name for her public persona. Ögi spent the year after marriage as a housewife before re-entering the entertainment industry and appearing in a range of television dramas, variety shows and commercials. While continuing her acting career she and Hayashi had two sons, born in 1959 and 1960, who later joined their father as Kabuki actors. Like most musumeyaku, Ōgi's retirement from Takarazuka at twenty-five years of age for the purpose of marriage and family-raising was considered natural. In the early days, Kobayashi was actively involved in organising "good" marriages for all performers at an appropriate age as determined by social norms, even if this conflicted with their individual aspirations (Robertson 1998, 17; see also Matsuo 2003, 96). ${ }^{5}$ Marriage was viewed as a desirable life goal and a key part of one's social identity, although this appears to be less so in contemporary Japan (Imamura 1990). 
Ōgi's legal surname became "Hayashi" in line with the custom of adopting a single surname for both spouses-usually but not always the husband'safter marriage. This symbolised her joining with her new family. Ōgi valued her role as a housewife and mother (Shimazaki 2006) and shifted her status and role expectations accordingly. At the same time, it was important for Ōgi to maintain her relationship with the Takarazuka stage, as indicated by her decision to retain her Takarazuka stage name after retiring from the company. This eventually became an asset in her political career as it sustained her professional identity and provided a tangible connection for voters, reminding them of her past performances as a musumeyaku.

From 1971 until 1977, Ōgi was co-host of the daytime television show "You at 3 o'clock” (三時のあなた), which she hosted alongside several other famous actresses including Yoshiko Ōtaka [1920-2014]. Garnering this role based on the popularity she had earned as a performer, Ōgi's experience with media personalities, including actors, singers and other performers, served her well in discussing popular culture issues for the show's main audience of housewives. At the time, gendered casting of female and male roles in mainstream television programming narrowed the scope of women's interests to the domestic sphere (Saito 2007). Daytime television was a relatively new concept and "You at 3 o'clock" separated itself from other television talk shows as there was an attempt to include discussions on contemporary news topics, such as the Vietnam War and the Israeli-Palestinian conflict. Although serious topics were typically hosted by male anchors, Ōgi's co-host Yoshiko Ōtaka had international experience as an actress and as a diplomat's wife, and conducted interviews with several international political leaders (Saito 2007). Nevertheless, gender roles on the show were clearly delineated, with the hosts expected to embody feminine characteristics such as physical beauty. Ōtaka expressed her reservations about her own selection as a host, saying "I suppose my appearance as a host served merely an ornamental purpose" (Yamaguchi and Fujiwara 2015, 285). With the theatrical communication skills developed during her time as a Takarasienne, Ōgi was able to effectively adapt to this new entertainment medium and expand her fan base.

\section{PERFORMING AS A POLITICIAN}

According to Newman (2008), each new generation finds ways to overcome the context-dependent circumstances they face. Ögi's long career as a politician suggests the effectiveness of her dextrous gender performance, arguably crucial in her widespread appeal to both her colleagues and voters as she gained positions of political power and prestige within a highly masculinised space. Based on the limitations Ōgi's generation of women faced, Ōgi's opportunities were enhanced when she learned as a Takarasienne to "observe, manipulate and modify orthodox gender roles for ... [her] own purposes" (Stickland 2004, 275), both on and off stage. Ögi's skill at representing a feminine identity through visual devices, such as mannerisms and clothing choices, helped her develop a successful campaign to appeal to conservative voters together with her male Party colleagues (Puwar 2004, 93). She also utilised male mentor support to ensure her inclusion in the inner circles, 
as external male patronage is one method for women to overcome career boundaries in the absence of family support (Lebra 2007b, 185).

In 1974, at the suggestion of the soon-to-be Prime Minister Takeo Fukuda [福 田 趃夫; 1905-1995] and while still working as a television host, Ögi decided to run for election. She was forty-four years of age at the time. After Fukuda became Prime Minister [1976-1978], Ögi successfully ran for election to the House of Councillors (Upper House) in 1977 as a member of the Liberal Democratic Party (自民党; LDP). Her father-in-law and husband had both objected when she had been approached to run for the LDP initially, deeming it “not suitable for a daughter-in-law of the Kabuki world” (梨園の嫁としてふさ わしくない) (Shimazaki 2006, 66). Before the 1977 election campaign, several male LDP members, including Fukuda, met with Ögi's family to show their support for her. After this, her father-in-law announced, "This time I would like to support my son's wife in the election” (おたくのお嫁さん、今度の参院選 に貸していただきたい) (Ōgi 2008, 232). Ōgi’s social networks and male LDP colleagues provided crucial support to help her overcome the strict gender roles enforced by her family. This was important as it enabled her to pursue her own goals unhindered by the conflict which would have occurred if she had challenged her family's wishes.

This was to be the beginning of a thirty-year (five-term) political career, making Ōgi one of the longest-serving female politicians in Japan. Her initial responsibilities included: Special Committee on the Environment (Public Nuisance Countermeasures and Preservation of the Environment) (1977); Special Committee on Traffic Safety member (1978); State Secretary for Science and Technology (1981); and Committee on Education (1985). This suggests the tendency to assign women "soft" subjects (such as childcare, science, consumer affairs, education, health) associated with "feminine" values, as opposed to the traditionally "masculine" areas of defence, foreign affairs and the economy (Puwar 2004, 89). These areas may have aligned with Ōgi's interests and been commensurate with her socialisation and experience, but such categorisation fails to recognise, and capitalise upon, the different perspectives women such as Ögi can bring to the more male-dominated policy areas (Phillips 1995, 62-3).

The consistently small percentage of women in the LDP indicates that it has not been particularly friendly to female candidates. The LDP began deploying female celebrity candidates in the 1970s, beginning with the famous actresses Akiko Santō [山東 昭子; b. 1942] and Yoshiko Ōtaka, who were candidates in the 1974 House of Councillors election. ${ }^{6}$ This was an early indicator of the increasingly common use of female 'talent' or celebrity candidates as a campaign strategy to mobilise and distract voters from difficult issues, such as the Lockheed bribery scandals in $1976 .{ }^{7}$

\footnotetext{
6 A recent example of this tactic are the 'Koizumi Children' (小泉チルドレン) of the 2005 election: 83 new LDP candidates, many of whom were young attractive female celebrities, were endorsed as part of a strategy to attract voters with young and famous faces.

7 From the 1950s to 1970s, officials from the US' Lockheed aerospace company bribed government officials and politicians in several nations in order to secure contracts, as the company was facing bankruptcy. Japan's LDP Prime Minister Kakuei Tanaka and his representatives received at least \$12 million from Lockheed. Lockheed also employed a Japanese war criminal because of his close connection to the LDP. When these dealings were uncovered, then-Prime Minister Tanaka was forced to resign, and was arrested and found guilty of violating Japan's foreign exchange laws.
} 
In 1977, the LDP was in a precarious position as it no longer held a clear majority in either house of the Diet. Forced to negotiate with other political parties, it endorsed female candidates with little political experience like Ōgi, which may have contributed to increasing the Party's popularity with female voters and renewing trust through an image of innocence (Derichs et al. 2006). This was not a serious effort to engage with female voters, however, as the LDP did little to mobilise women's votes, despite their consistently higher electoral numbers than men (Mackie 1989, 23-4). Overall, LDP policies and the dominant attitudes of male Party politicians exhibited contempt for the disadvantages faced by women and ignored their needs in the decisionmaking process. Instead, they aimed to exploit the image of femininity and the innocence of selected female candidates without actually changing the status quo (Derichs et al. 2006).

Ōgi's stage and media personality served her well upon her entry into politics. She was known in media as the "LDP Mascot Girl” (自民党のマスコットガー ル) and “Ex-Actress from Takarazuka” (宝塚出の女優あがり), and attracted headlines such as "A Beautiful Woman's Pulling Power rather than Political Power” (政治力より美人の吸引力) (Shimazaki 2006, 59). Ōgi recalled that during her election campaigns she was surrounded by supporters calling her name, thanks to her public exposure on "You at 3 O'Clock" (Ōgi 2008, 235). Ögi's sense of agency grew with her political successes, but paradoxically, rather than empowering Ōgi, her public image and the LDP's strategic use of her identity undermined her achievements and abilities.

Scholars have identified three aspects of electioneering which are viewed as essential in winning an election: jiban (地盤; support), kanban (看板; name recognition) and kaban (鞄; lit., 'bag', referring to financial support by evoking the image of a bag full of money) (Kubo and Gelb 1994, 133). Women face significant hurdles throughout their life course that reduce their access to the necessary opportunities for a successful political career (Kato 2009). Even so, in Ōgi's case her career in show business and her marriage to a famous Kabuki actor allowed her to fulfil two of the above criteria: jiban and kanban. Ögi's fame increased her chance of election (and maintaining her seat), reduced the Party's financial expenses (as they were campaigning for a known candidate), and made her re-election in the Upper House more likely (as she was able to appeal across constituencies, which has proven a more successful strategy for female candidates) (Eto 2010, 183; Kubo and Gelb 1994, 133). Her conservative attitudes and performance of traditional gender roles aligned with the LDP, which she had also supported before her election (Ōgi 2008, 226), and underpinned Ōgi's rise by allowing her to overcome the obstacles presented by her parents' and husband's objections to reach her goals.

Ōgi was voted out of her seat in 1989 but continued to campaign and won back her position in the Upper House in 1993. In 1994, she left the LDP in favour of the Japan Renewal Party (新生党; JRP), which was created the previous year when LDP reformers Tsutomu Hata [羽田 孜; b. 1935] and Ichirō Ozawa [小沢 一郎; b. 1942] defected and began their own party. The JRP had been instrumental in the LDP's brief fall from power in 1993, as it had joined with six other smaller parties to form a coalition government (Hori 2006). One 
of Ōgi's aims was to simplify the Constitution by clarifying controversial aspects-particularly Article 9, which did not permit the use of land, sea or air forces to settle international disputes-and to reform educational policy to address issues such as bullying (Maeda 2000). The LDP had long manipulated the terminology found in Article 9 to allow them to build up significant military forces (i.e., Japan Self-Defense Force); they also exploited lax provisions to engineer the electoral system to their advantage (McElwain 2008) and interfered with job assignment procedure in the courts to influence the selection of court judges (Ramseyer and Rasmusen 2010, 125-27). Ōgi had ethical concerns about these issues (Maeda 2000). In contrast, the JRP appeared to offer Ögi the opportunity to achieve her desired reforms (as the LDP had reneged on its promises of reform) and this was her main motivation for leaving the LDP.

In December 1994, the JRP formed the New Frontier Party (新進党; NFP), comprising several smaller political parties with diverse platforms. In 2000, Ōgi then founded the New Conservative Party (保守新党; NCP) in which she promised to lay the "moral ground" for Japan (Maeda 2000). The NCP became part of a ruling coalition with the LDP and the Kōmeitō party (公明党). Under the coalition, Ōgi became Minister for Construction (2000), Minister for Transport (2000) and Minister for Land, Infrastructure and Transport (2001) (Prime Minister of Japan 2002a). In this coalition government, Ögi's party was able to negotiate for her desired reforms. She also pragmatically agreed to merge with the LDP if the NCP's performance made the achievement of these aims unlikely. The NCP was dissolved in 2002 and Ogi returned to the LDP shortly after in 2003.

The following year, Ögi was appointed as the 26th President of the House of Councillors, becoming the first woman in Japan to achieve this position (Puwar 2004). Ogi used this role to meet with world leaders in Africa, the United States and China to foster and promote cooperation between nations, with a focus on improving Japan-China relations ( $\mathrm{Mu}$ 2006). Then-President $\mathrm{Hu}$ Jintao described Ōgi's visit to China, the first Japanese representative at that level since 1999, as a "turning point" in China-Japan relations (Lu 2006). She was honoured for her contributions with several awards, including Japan's Grand Cordon of the Order of the Rising Sun (旭日大綬章) in 2003 as the first female recipient, ${ }^{8}$ South Korea's Order of Diplomatic Service Merit, Grade One (修交勲章光化章) in 2005 and China's Order of the Brilliant Star, First Class (一等景星勲章) in 2008 (Ōgi 2008, 144-45).

\section{PERFORMING GENDER IN POLITICS}

In this section, I will compare and contrast Ōgi's appearance in a visual analysis of Cabinet photographs. Costuming and colour choice play a key role in the representation of gender within Takarazuka performances, and Ōgi utilised similar principles throughout her political career, often appearing in soft colours or variants of pink and red. However, striking a balance between performing femininity and asserting one's professional capability in 
the political world is more complex than simply choosing the 'right' colour. Over-emphasising one's femininity can result in restricting one's political assignments to "women's issues" (Dalton 2008b, 56), while challenging them can make one an obvious target of criticism in terms of political suitability (Flicker 2013). Nonetheless, Ōgi's long and successful tenure as a politician, and particularly her appointment to traditionally male-dominated roles, shows that she skilfully navigated this double bind to maintain a balance of femininity and professional credibility.

Dress is a crucial aspect in the performance of gender in Japan (Monden 2015, 6), as it is elsewhere. Clothing and aesthetic appearance in Japanese society play a foundational role in defining the boundary between self and society, and in perpetuating gender norms (Mackie 2009). Masculinity is bound to and codified in suit-based clothing as the uniform dress code for male politicians and white-collar workers, allowing for little visual variation aside from the colour of one's tie. This uniformity also existed with traditional forms of male dress prior to the adoption of the Western morning suit over the kimono in the Meiji period. The context of the suit's introduction also associated the male wearer with progress and modernisation, whereas the female kimono remained a symbol of traditional Japan. In this way, the male body and masculinity have consistently been defined against and separated from the 'feminine' in Japan (Slade 2009, 96-97). In the suited male figure, the emphasis on the chest and shoulders symbolises "reserve, stature and efficiency" (Monden 2015, 24) and reinforces the status associated with this posture in the public sphere.

Women's physical absence from politics until electoral rights were granted in 1945 meant that strict dress codes for women in the political sphere were not firmly established. As women are given a greater range of dress choices, many female politicians have used their dress and appearance to portray certain images to voters about their character and their position within social norms. There is still a large gender disparity among Japanese parliamentary figures, with female politicians-and their generally more colourful clothing-in the minority. As a result, the colours worn by female politicians stand out beside the uniform colours (generally black) of their male colleagues' suits. Ōgi used this to her advantage, ensuring that her aesthetics of dress communicated an adherence to the feminine. Her colourful presence also emphasises her difference in a masculine space (Flicker 2013, 205). This difference is accepted because Ōgi successfully uses dress to conform to the normative expectations of her party.

In five Cabinet photographs taken between 2000 and 2002, Ōgi appears in either traditional Japanese kimono (Figures 3 and 5) or Western-style evening dresses and ladies' suit jackets (Figures 1,2 and 4). The kimono is a "marked feminine costume" strongly related to Japanese identity and tradition (Goldstein-Gidoni 1999, 351). Ōgi's choice to wear kimono reflects traditional Japanese aesthetic values and feminine beauty ideals. There are customary stipulations on kimono style, patterns and colours based on context, age and marital status (Sato 2010); the subdued colours of Ōgi's kimono would be 
seen as a culturally suitable choice for a mature-age woman (Bolich 2007, 211; Sato 2010,24). Western attire, in contrast, is less attached to traditional codes and tends to be associated with modernity and progress (Goldstein-Gidoni 1999, 351). In alternating between Japanese and Western dress, Ōgi asserts her Japaneseness and her femininity, while at the same time reminding the viewer of her political capacity in a modern world. Her group positioning in the foreground of the photographs (in recognition of her long tenure as a politician) enhances her visibility. Ogi wears her hair short in all five photographs, which contrasts with the long hair of her Takarazuka days. While long hair is traditionally associated with feminine youth and beauty, short hair in women may be seen as symbolising maturity, and hence as more appropriate for the political sphere.
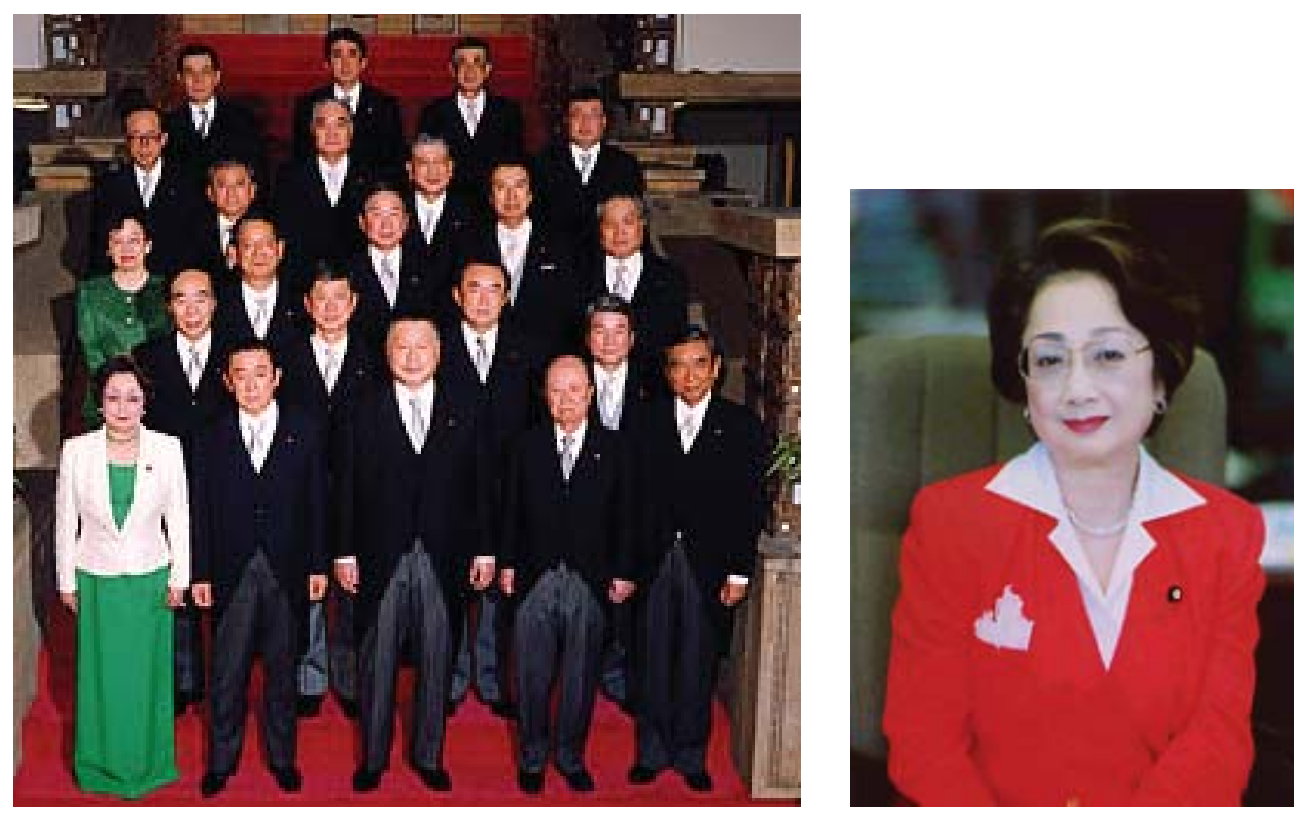

Figure 1 (left): Commemorative photo of the Second Tsugimori Cabinet Reshuffle, 5th December, 2000. Ōgi: front row, left; Kawaguchi: third row, left. (Source: Prime Minister of Japan 2000)

Figure 2: Chikage Ōgi's official profile picture (Source: Prime Minister of Japan 2002a)

Figure 1 features Ōgi in 2000, in her first appointment to the Cabinet as Minister for Transport while she was leader of the NCP. Yoriko Kawaguchi [川口順子; b. 1941] and Ōgi both appear in emerald green. Kawaguchi's body is obscured from view behind Ōgi, but the formal lines of her attire are visible. Ögi's eye-catching combination of a green, floor-length Western-style gown with a white suit jacket hides the body and emphasises flow, as does a kimono (Slade 2009, 97). The distinct framing of her upper body as the suit jacket outlines her shoulders is a modern signifier of professionalism and business. Ōgi also wears a suit jacket in Figure 2, which-as her official profile pictureis arguably the most prominent visual representation of her as a political figure. As in this image, Ōgi is often pictured in a red suit jacket with a white blouse underneath: the national colours of Japan.

Figure 3 shows Ōgi in a pale gold kimono, the smooth lines and folds of which conceal the contours of the body. Kimono as formal wear for women on important occasions is a symbol of femininity and national tradition 
(Goldstein-Gidoni 1999, 351). In contrast, the Western suit symbolises "national action and achievement" (Goldstein-Gidoni 1999, 351). Due to her placement in the photo, Ōgi's kimono adds colour to the mostly dark suits surrounding her and also draws attention away from her colleague Kawaguchi, who wears darker colours.

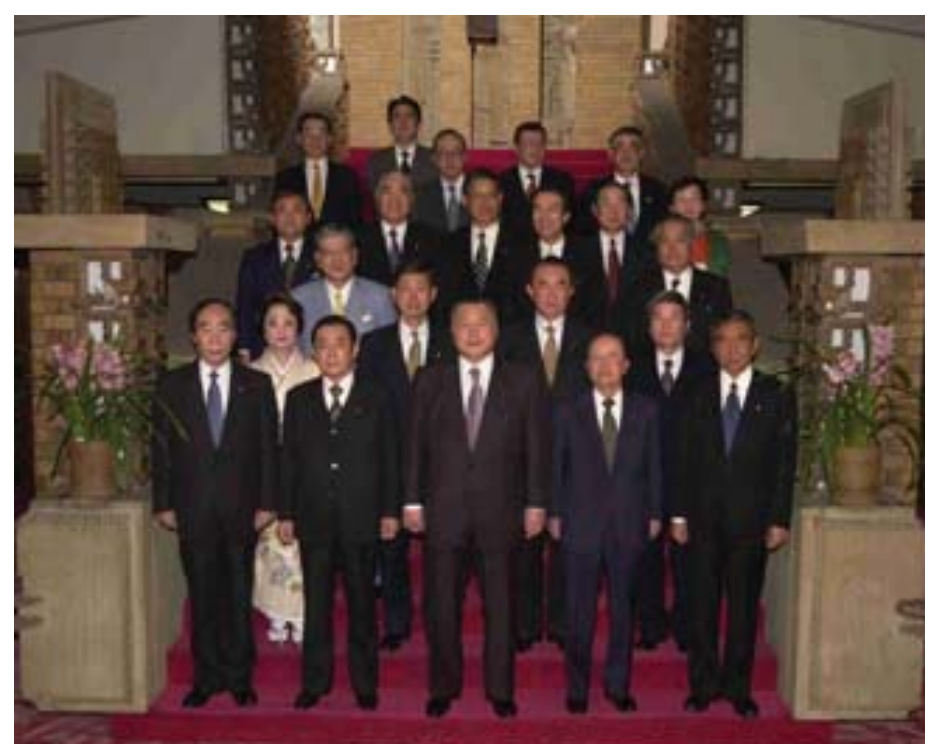

Figure 3: Commemorative photo of the Second Tsugimori Cabinet Reshuffle, 6th January, 2001. Ōgi: second row, left; Kawaguchi; fourth row, right. (Source: Prime Minister of Japan 2001b).

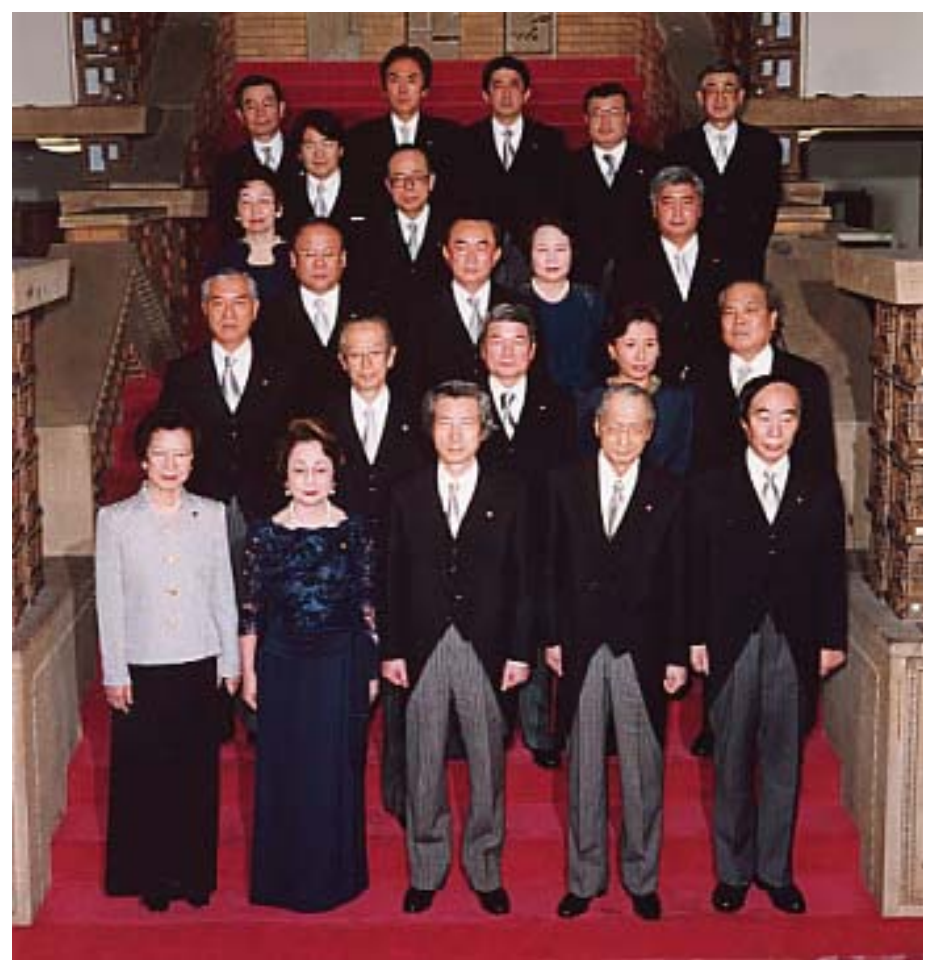

Figure 4: Primary Koizumi Cabinet, 26th April, 2001. Ōgi: front row, second from left; Kawaguchi: front row, left; Tanaka: second row, fourth from left; Toyama: third row, third from left; Moriyama: fourth row, left. (Source: Prime Minister of Japan 2001a)

The 2001 Cabinet under Jun'ichirō Koizumi featured a record number of female ministers, with Makiko Tanaka [田中 眞紀子; b. 1944], Mayumi Moriyama [森山 眞弓; b. 1927] and Atsuko Toyama [富山 敦子; b. 1938] joining Ōgi and 
Kawaguchi. Unlike the Cabinet photographs, Ōgi and the three newcomers all dress in a dark navy blue, with the exception of Kawaguchi in black and grey. Ögi's front-row positioning next to Kawaguchi gives her optimum visibility, while the navy-coloured dresses of her female colleagues blend in with men's darker suits. Perhaps their choice of dark colours on this occasion was a conscious decision to present a more disciplined, united image of the Party. Kawaguchi's positioning in the front row and her grey suit jacket with padded shoulders present a bold, businesslike appearance. These differences set her apart from both her female and male counterparts. Ōgi's refined navy evening dress with lace brocade sleeves shares the colour scheme adopted by her other female colleagues, but the dress is more feminine than the sharper shoulders on Tanaka's navy dress, for example. Here, Ōgi's flowing dress with softened shoulders and concealed body does not borrow any masculine aesthetic elements and reinforces a feminine ideal rooted in traditional aesthetic standards (Goldstein-Gidoni 1999, 360-62).

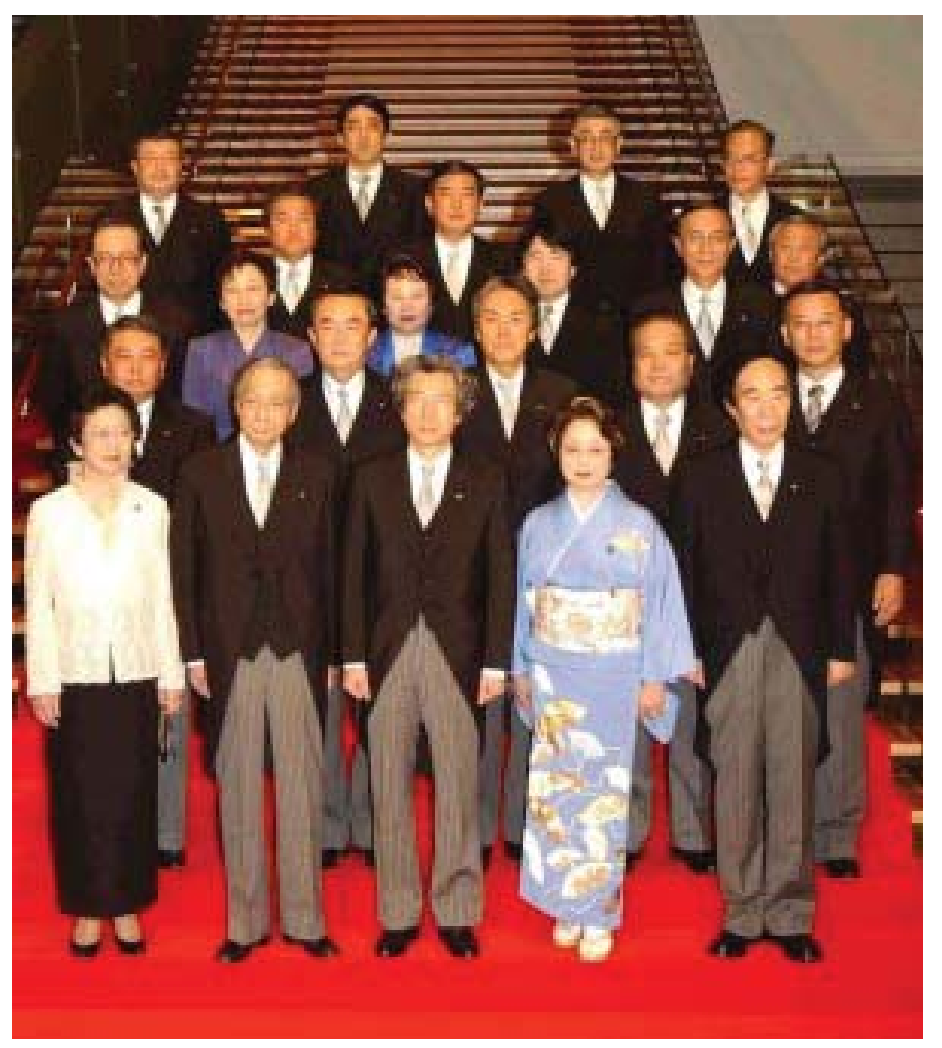

Figure 5: Commemorative photo of the Primary Koizumi Cabinet First-Order Reshuffle, 30th September, 2002. Ōgi; front row, fourth from left; Kawaguchi: front row, left; Moriyama: third row, second from left; Toyama: third row, third from left. (Source: Prime Minister of Japan 2002b)

In Figure 5, Ōgi wears a powder-blue patterned kimono and geta (下駄). ${ }^{9}$ She is distinct as the only Cabinet member in traditional Japanese dress. Although all women are visible and wear blue hues, Ōgi's appearance contrasts with those of Kawaguchi, Moriyama and Toyama who all wear suit jackets. The time and restraint involved in wearing a kimono suggest mores of endurance and patience, which are cherished in Japanese traditions (Goldstein-Gidoni 1999, 161-62). Both here and in the photos above, Ōgi's choice of dress 
is unique and stands as a clear reminder that she represents the core of normative Japanese femininity. The above images illustrate how women can use costuming to communicate ideas about their social and gender roles and personalities, which are then reinforced by their performances in the public sphere (Puwar 2004; Dalton 2008b).

Such readings of self-presentation by present-day politicians, both female and male, can be problematic for both the empowerment of female politicians and their effects on the wider community. Despite Ōgi's dexterity in deploying a feminine image as a method of winning votes and intra-political support, her public statements have perpetuated stereotypes about women's roles as wives and mothers. One example is her remark following the birth of Princess Kiko's child: "We women should learn from the princess's courage in overcoming the pain of a caesarian section and giving birth to her third child" (China Daily 2006)..$^{10}$ Ogi's statement reinforces normative expectations that women will bear children. In her own life also, Ōgi embraced the normative expectation of being a supportive wife (Shimazaki 2006, 70), possibly to the detriment of her career. On the other hand, by perpetuating the normative gender expectations supported by many Japanese male and female politicians, she was able to progress in her career. Recognition of this may lie behind her public response to her husband's infidelity ("I know that girl. She is intelligent and I favour her, too. A husband not attractive to women would be boring"), and her view on another parliamentarian's affair ("For a man, it is better that he is virile. My husband, too, has had his share of affairs") (Kwan 2000), although it is impossible to determine whether these comments are born from political opportunism or actually reflect her true beliefs. What can be safely assumed is that Ōgi is strongly conservative in her values, and is adept at manipulating her public image to appeal to conservative voters, her Party members and LDP backers.

\section{CONCLUSION}

Ōgi provides an example of a female politician who embraced traditional and conservative notions of femininity and used these to build her career. In this paper, I have analysed the ways in which past experiences and sociocultural contexts played a key role in conditioning Ōgi's access to opportunities. Her family was a strong source of socialisation and directed her toward becoming a good wife. These attitudes affected her degree of agency and ability to make independent choices for her life course (Hutchinson 2001, 27-8). Despite the objections from her father, father-in-law and husband, Ōgi utilised the skills she developed through her Takarazuka training to deploy an image of femininity, and leveraged her experience in show-business to appeal to voters and to members within the masculine culture of the LDP. Ultimately, it is this that allowed her to become a successful politician. 


\section{ACKNOWLEDGEMENTS}

Appreciation is extended to my $\mathrm{PhD}$ supervisor, Dr Mio Bryce, for her feedback and encouragement. Support for this research was contributed by a Macquarie University Research Excellence Scholarship (MQRES).

\section{APPENDIX I}

\section{Chikage Ōgi Chronology}

1933 Born Hiroko Kimura (木村 寛子) in Kobe, Hyogo prefecture

1952 Graduates from Hyogo Prefectural Kobe High School and enters

Takarazuka Music School

1954 Joins Takarazuka Revue as a musumeyaku, taking the stage name ‘Chikage Ōgi’ (扇 千景)

1957 Retires from Takarazuka Revue in order to marry

1958 Marries Kabuki actor Kōtarō Hayashi (林 宏太郎), whose stage name is Tōjūrō Sakata IV (四代目 坂田 藤十郎). Changes official name to Hiroko Hayashi (林 寛子)

1959 Re-enters entertainment industry, appearing in television dramas, variety shows and commercials Birth of first son, Tomotarō Hayashi (林 智太郎), whose stage name becomes Nakamura Kanjaku IV (四代目 中村鴈治郎)

1960 Birth of second son, Kōtarō Hayashi (林 宏太郎), whose stage name becomes Nakamura Senjaku III (三代目 中村 扇雀)

1971 Becomes regular co-host of the daytime television show, "You at 3 o'clock" (三時のあなた)

1974 Approached by Takeo Fukuda (福田 趣夫) to run in the House of Councillors election

1977 Retires from hosting "You at 3 o'clock"

Endorsed by Liberal Democratic Party (自民党; LDP)

Elected to the Upper House, also known as the House of Councillors (参議 院)

Member, Special Committee on the Environment (Public Nuisance

Countermeasures and Preservation of the Environment) (公害及び環境保全 特別委員)

1978 Director, Special Committee on Traffic Safety (交通安全対策特別委員)

1979 Director, Committee on Cabinet (内閣委員会理事)

Member, Special Committee on Energy（エネルギー対策特別委員） 
1980 Director, Special Committee on Science and Technology

(自民党科学技術部会長)

Member of Japanese National Commission for UNESCO

(日本ウネスコ国内委員)

1981 State Secretary, Science and Technology (科学技術政務次官)

1983 Director, Special Committee on Science and Technology (科学技術部会長)

1985 Chairperson, Committee on Education (参議院文教委員長)

1989 Voted out of Upper House

1993 Re-elected to Upper House

Director, Special Committee on Science and Technology (科学技術部会長)

1994 Leaves LDP to join the Japan Renewal Party (新生党; JRP)

JRP merges into New Frontier Party (新進党; NFP)

1995 Director, Committee on Discipline

Member, Committee on Education (文教委員)

Member, Special Committee on Science and Technology (科学技術特別委員)

1997 Member of National Land Council (国土審議委員)

Member of Special Committee on Development of the Tokyo Metropolitan

Area (首都圈整備特別委員)

1999 Member, Committee on Education, Culture and Science (文教科学委員)

Member, Deliberative Council on Political Ethics (政治倫理審査委員)

2000 Founds New Conservative Party (保守新党; NCP), which joins with LDP and Kōmeitō (公明党) to form ruling coalition

Minister for Construction (建設大臣)

Minister for Transport (運輸大臣)

Director-General of the National Land Agency (国土庁長官)

Director-General of the Hokkaido Development Agency (北海道開発庁長官)

2001 Minister for Construction (建設大臣)

Minister for Land, Infrastructure and Transport (国土交通大臣就任)

2002 NCP dissolves

2003 Returns to LDP

Awarded Japan's Grand Cordon of the Order of the Rising Sun

(旭日大綬章) (first female recipient)

2004 Appointed 26th President of the House of Councillors (第26代 参議院議長), becoming the first woman to attain this position

2005 Awarded South Korea’s Order of Diplomatic Service Merit, Grade One (修交勲章光化章)

2006 Lead a delegation to China as President of the House of Councillors 
2008 Awarded China’s Order of the Brilliant Star, First Class (一等景星勲章)

\section{APPENDIX II}

\section{Glossary of Japanese Terms}

\section{Geta [下䭾]}

Traditional Japanese sandals with an elevated base worn with kimono

Ie [家]

Stem-family system; sometimes referred to as ie seido [家制度]

Jiban [地盤]

Support or power base; known in Japan as one of the three criteria for becoming a successful politician

\section{Kaban [鞄]}

Financial support (lit., 'bag', referring to financial support by evoking the image of a bag full of money); known in Japan as one of the three criteria for becoming a successful politician

\section{Kanban [看板]}

Name recognition (lit., 'billboard'); known in Japan as one of the three criteria for becoming a successful politician

Kiyoku, tadashiku, utsukushiku [清く、正しく、美しく]

The Takarazuka motto, "With purity, honesty, [and] beauty"

\section{Musume [娘]}

Daughter; also used colloquially to mean 'young girl'

\section{Musumeyaku [娘役]}

Lit., 'daughter role'; female actor who plays young female roles in Takarazuka performances

Onnagata [女形]

Male actor who plays female roles in Kabuki theatre

\section{Onnayaku [女役]}

Lit., 'woman role'; female actor who has graduated to older female roles in Takarazuka performances

Otokoyaku [男役]

Lit., 'male role'; female actor who plays male roles in Takarazuka performances

\section{Otōsan [お父さん]}

Father 


\section{REFERENCES}

Banerjee, P. 2010. "Preface." In Women in Peace Politics, edited by P. Banerjee, xi-xix. New Delhi: Sage Publications India.

Bengsten, V. L. and K. R. Allen. 1993. "The Life Course Perspective Applied to Families Over Time." In Sourcebook of Family Theories and Methods: A Contextual Approach, edited by P. G. Boss, W. J. Doherty, R. LaRossa, W. R. Schumm and S. K. Steinmetz, 469-99. New York: Springer.

Berlin, Z. 1991. “The Takarazuka Touch.” Asian Theatre Journal 8 (1): 35-47. http://dx.doi.org/10.2307/1124165.

Bolich, G. G. 2007. Transgender History \& Geography: Crossdressing in Context, Volume 3. Raleigh, North Carolina: Psyche's Press.

Brau, L. 1990. “The Women's Theatre of Takarazuka.” TDR (1988-) 34 (4): 79-95. http://dx.doi.org/10.2307/1146045.

Chen, Y. 2010. "Gender and Homosexuality in Takarazuka Theatre: Twelfth Night and Epiphany." Performing Ethos 1 (1): 53-67. http://dx.doi.org/10.1386/ peet.1.1.53_1

China Daily. 2006. "Royal Birth Raises Profile of Princess Kiko.” September 7. Accessed 22 October, 2015. http://www.chinadaily.com.cn/world/ 2006-09 /07/content_683778.htm.

Dalton, E. 2008a. "A Masculinised Party Culture: Obstacles Facing Women in Japan's Liberal Democratic Party." Paper presented at the 17th Biennial Conference of the Asian Studies Association of Australia, Melbourne, Australia, July 1-3.

Dalton, E. 2008b. "The Utilization of Discourses of Femininity by Japanese Politicians: Tanaka Makiko Case Study." Graduate Journal of Asia-Pacific Studies 6 (1): 51-65.

Dalton, E. 2011. "The LDP and the Maintenance of Gender Inequality in Japanese Politics." PhD dissertation, University of Wollongong.

Dalton, E. 2015. Women and Politics in Contemporary Japan. New York: Routledge.

Derichs, C., A. Fleschenberg and M. Hüstebeck. 2006. "Gendering Moral Capital: Morality as a Political Asset and Strategy of Top Female Politicians in Asia." Critical Asian Studies 38 (3): 245-70. http://dx.doi.org/10.1080/14672710600 869665

Elder, G. H. 1998. "The Life Course as Developmental Theory." Child Development 69 (1): 1-12. http://dx.doi.org/10.2307/1132065. 
Eto, M. 2010. "Women and Representation in Japan: The Causes of Political Inequality." International Feminist Journal of Politics 12 (2): 177-201. http://dx.doi.org/10.1080/14616741003665227

Flicker, E. 2013. "Fashionable (Dis-)Order in Politics: Gender, Power and the Dilemma of the Suit." International Journal of Media \& Cultural Politics 9 (2): 201-19. http://dx.doi.org/10.1386/macp.9.2.201_3.

Goldstein-Gidoni, O. 1999. "Kimono and the Construction of Gendered and Cultural Identities." Ethnology 38 (4): 351-370. http://dx.doi.org/10.2307/3773912

Hori, H. 2006. The Changing Japanese Political System: The Liberal Democratic Party and the Ministry of Finance. London: Routledge.

Hutchinson, E. D. 2001. "A Life Course Perspective." In Dimensions of Human Behaviour: The Changing Life Course, edited by E. D. Hutchinson, 1-38. Los Angeles: Sage Publications.

Imamura, A. 1990. “The Japanese Family.” Asia Society: 7-17.

Iwao, S. 1993. The Japanese Woman: Traditional Image and Changing Reality. New York: The Free Press.

Japan Today. 2014. “Tokyo Assemblywoman Heckled on Why She Isn't Married or Having Children.” 20 June. Accessed 21 June, 2014. http://www.japantoday. com/category/politics/view/tokyo-assemblywoman-heckled-about-whyshe-isnt-married-or-having-children.

Kato, S. 2009. Hereditary Lawmakers in an Era of Politically Led Policymaking (1). The Tokyo Foundation. Accessed 5 April, 2015. http://www.tokyofoundation. org/en/articles/2009/hereditary-lawmakers-in-an-era-of-politically-ledpolicymaking-1.

Kobayashi, K. [小林 公一]. 2014. Takarazukageki 100-nenshi niji no hashi watari tsuzukete (jinbutsu hen) [宝塚歌劇100年史 虹の橋 渡り続けて (人物編) ]: Hankyū komyunikēshonzu [阪急コミュニケーションズ].

Kubo, K. and J. Gelb. 1994. "Obstacles and Opportunities: Women and Political Participation in Japan." In Women of Japan and Korea: Continuity and Change, edited by J. Gelb and M. L. Palley, 120-49. Philadelphia: Temple University Press.

Kwan, W. K. 2000. "For a Man, it is Better that he is Virile. My Husband Too has had his Share of Affairs." The Straits Times, October 28. Accessed 20 October, 2015. http://eresources.nlb.gov.sg/newspapers/Digitised/Issue/ straitstimes20001028-1.aspx.

Lebra, T. 2007a. "Confucian Gender Roles and Personal Fulfillment for Japanese Women." In Collected Papers of Takie Lebra: Identity, Gender and Status in Japan, edited by T. Lebra, 248-63. North Yorkshire, England: Global Oriental. http://dx.doi.org/10.1163/ej.9781905246175.i-439.127 
Lebra, T. 2007b. "Japanese Women in Male-Dominant Careers: Cultural Barriers and Accommodations for Sex-Role Transcendence." In Collected Papers of Takie Lebra: Identity, Gender and Status in Japan, edited by T. Lebra, 177-95. North Yorkshire, England: Global Oriental. http://dx.doi.org/ 10.1163/ej.9781905246175.i-439.112

Lu, H. 2006. China, Japan Set Up Regular Exchange Mechanism. Accessed 14 May, 2016. http://news.xinhuanet.com/english/2006-10/17/content_5213419.htm.

Mackie, V. C. 1989. “A New Age for Women and Politics in Japan?” Japanese Studies 9 (3): 23-26.

Mackie, V. C. 2009. “Transnational Bricolage: Gothic Lolita and the Political Economy of Fashion." Intersections: Gender and Sexuality in Asia and the Pacific, 20. Accessed 15 October, 2015. http://intersections.anu.edu.au/ issue20/mackie.htm.

Maeda, T. 2000. "Ogi's New Conservatives Aim to Lay Japan's 'Moral Ground'." June 17. Accessed 20 October, 2015. http://www.japantimes.co.jp/news/2000/ 06/17/news/ogis-new-conservatives-aim-to-lay-japans-moral-ground/.

Matsuo, H. 2003. The Transition to Motherhood in Japan: A Comparison with the Netherlands. Amsterdam: Rozenberg Publishers.

McElwain, K. M. 2008. "Manipulating Electoral Rules to Manufacture Single-Party Dominance." American Journal of Political Science 52: 32-47.

Monden, M. 2015. Japanese Fashion Cultures: Dress and Gender in Contemporary Japan. London: Bloomsbury Academic.

Morton, W. S. and J. K. Olenik. 2005. Japan: Its History and Culture. 4th edition. New York: McGraw-Hill Books.

Mu, X. 2006. Top Advisor Outlines Development of China-Japan Relations. Accessed 13 February, 2016. http://www.gov.cn/english/2006-10/16/content_414909. htm.

Newman, K. 2008. "Rising Angst? Change and Stability in Perceptions of Economic Insecurity." In Laid Off, Laid Low: Political and Economic Consequences of Employment Insecurity, edited by K. Newman, 74-101. New York: Columbia University Press and The Social Science Research Council.

Nocedo, A. M. A. 2012. "The 'Good Wife and Wise Mother' Pattern: Gender Differences in Today's Japanese Society." Crítica Contemporánea. Revista de Teoría Politica (November): 156-169. http://www.fcs.edu.uy/ archivos/Ara\%C3\%BAjo(1).pdf.

Ōgi, C. [扇 千景]. 2001. “Dekiru koto dekinai koto [できることできないこと].” Tokyo: Nihon Keizai Shimbun Publishing Company.

Ōgi, C. [扇 千景]. 2008. “Tsuma no rirekisho [妻の履歴書].” In Fūfu no rirekisho [夫 婦の履歴書], edited by T. Sakata [坂田 藤十郎] and C. Ōgi [扇 千景]. Tokyo: Nihon Keizai Shimbun Publishing Company. 
Prime Minister of Japan and His Cabinet. 2000. “Dai niji Mori naikaku” [第2次森 内閣]. Accessed 1 February, 2016. http://www.kantei.go.jp/jp/rekidai/ kakuryo/86-1.html.

Prime Minister of Japan and His Cabinet. 2001a. "Dai ichiji Koizumi naikaku” [第1 次小泉内閣]. Accessed 1 February, 2016. http://www.kantei.go.jp/jp/rekidai/ kakuryo/87.html.

Prime Minister of Japan and His Cabinet. 2001b. “Dai niji Mori naikaku” [第2次森 内閣]. Accessed 1 February, 2016. http://www.kantei.go.jp/jp/rekidai/ kakuryo/86-1new.html.

Prime Minister of Japan and His Cabinet. 2002a. "Minister of Land, Infrastructure and Transport: Chikage Oogi”. Accessed 18 October, 2015. http://japan. kantei.go.jp/koizumidaijin/020930/10ogi_e.html.

Prime Minister of Japan and His Cabinet. 2002b. "Dai ichiji Koizumi naikaku” [第1 次小泉内閣]. Accessed 1 February, 2016. http://www.kantei.go.jp/jp/rekidai/ kakuryo/87-1.html.

Puwar, N. 2004. Space Invaders: Race, Gender and Bodies out of Place. Oxford, New York: Berg.

Ramseyer, J. M. and E. B. Rasmusen. 2010. Measuring Judicial Independence: The Political Economy of Judging in Japan. Chicago: University of Chicago Press.

Reitan, R. 2011. "Claiming Personality: Reassessing the Dangers of the 'New Woman' in Early Taishō Japan." Positions 19 (1): 83-107. http://dx.doi. org/10.1215/10679847-2010-025.

Robertson, J. 1991. "Theatrical Resistance, Theatres of Restraint: The Takarazuka Revue and the 'State Theatre' Movement in Japan." Anthropological Quarterly 64 (4): 165-77. http://dx.doi.org/10.2307/3317210.

Robertson, J. 1992. "The Politics of Androgyny in Japan: Sexuality and Subversion in the Theater and Beyond." American Ethnologist 19 (3): 419-42. http:// dx.doi.org/10.1525/ae.1992.19.3.02a00010

Robertson, J. 1998. Takarazuka: Sexual Politics and Popular Culture in Modern Japan. Berkeley: University of California Press.

Rosenthal, C. S. 2008. "Climbing Higher: Opportunities and Obstacles within the Party System." In Legislative Women: Getting Elected, Getting Ahead, edited by B. Reingold. Colorado, USA: Lynne Reiner Publishers.

Saito, S. 2007. "Television and the Cultivation of Gender-Role Attitudes in Japan: Does Television Contribute to the Maintenance of the Status Quo?" Journal of Communication 57 (3): 511-31.

Sato, C. J. 2010. "Regarding Fashions in 20th Century Women's Kimono." Masters thesis. RMIT University. 
Shimazaki, K [島崎 今日子]. 2006. “Seijika一Ōgi Chikage: hiirō o koenai hiroin” [政 治家一扇千景：ヒーローを超えないヒロイン]. In Kono kuni de onna de aru to iu koto [この国で女であるといらこと], 57-70. Tokyo: Chikuma shobō [筑摩書房].

Singer, J. 1996. “The Dream World of Takarazuka.” Japan Quarterly 43 (2): 162-81.

Slade, T. 2009. Japanese Fashion: A Cultural History. Oxford: Berg.

Statistics Bureau of Japan. 2015. Statistical Handbook of Japan. Ministry of Internal Affairs and Communications. Accessed 1 August, 2015. http://www.stat. go.jp/english/data/handbook/c0117.htm.

Stickland, L. R. 2004. "Gender Gymnastics: Performers, Fans and Gender Issues in the Takarazuka Revue of Contemporary Japan." PhD dissertation, Murdoch University.

Tachibanaki, T. 2010. The New Paradox for Japanese Women: Greater Choice, Greater Inequality. Translated by M. E. Foster. Tokyo: International House of Japan Inc.

Takarazuka Music School. 2015. Takarazuka Music School. Accessed 22 October, 2015. http://www.tms.ac.jp/english/about.html.

Ueda, Y. [上田 善次]. 1974. Takarazuka sutā: sono engi to bungaku [宝塚スター:その 演技と美学]. Tokyo: Yomiuri shinbunsha [読売新聞社].

Ueno, C. 2009. The Modern Family in Japan: Its Rise and Fall. Balwyn North, Vic: Trans Pacific Press.

United States Strategic Bombing Survey. 1947. Effects of Air Attack on Osaka, Kobe, Kyoto. U.S. Govt. Print. Off.

Uno, K. 2005. "Womanhood, War, and Empire: Transmutations of 'Good Wife, Wise Mother' before 1931.” In Gendering Modern Japanese History, edited by B. Maloney and K. Uno, 493-519. Cambridge: Harvard University Press.

Yamaguchi, Y. and S. Fujiwara. 2015. Fragrant Orchid: The Story of My Early Life. Translated by C. Chang. Honolulu: University of Hawai'i Press.

Yamanashi, M. 2012. A History of the Takarazuka Revue Since 1914. Leiden: Global Oriental. 